UNIVERSIDADE DE SÃO PAULO

FACULDADE DE FILOSOFIA, LETRAS E CIÊNCIAS HUMANAS

DEPARTAMENTO DE LETRAS CLÁSSICAS E VERNÁCULAS

PROGRAMA DE PÓS-GRADUAÇÃO EM LITERATURA BRASILEIRA

\title{
MANUSCRITOS DE OUTROS ESCRITORES \\ NO ARQUIVO MÁRIO DE ANDRADE: PERSPECTIVAS DE ESTUDO
}

Marcia Regina Jaschke Machado

(marcia.machado@usp.br)

Dissertação apresentada ao Programa de Pós-Graduação em Literatura Brasileira, do Departamento de Letras Clássicas e Vernáculas da Faculdade de Filosofia, Letras e Ciências Humanas da Universidade de São Paulo, para obtenção do título de Mestre em Letras.

Orientadora: $\operatorname{Prof}^{a} \operatorname{Dr}^{a}$ Therezinha Apparecida Porto Ancona Lopez

São Paulo

2005 


\section{AGRADECIMENTOS}

- Equipe Mário de Andrade: Telê Ancona Lopez; Tatiana Maria Longo dos Santos, Rosângela Asche de Paula, João Francisco, Flávia Nunes, Ana Cândida Avelar, Aline Nogueira Marques;

- Profs. Drs. Marcos Antonio de Moraes, Yêdda Dias Lima; Philippe Willemart, Roberto de Oliveira Brandão, Roberto Zular, Flávia Camargo Toni; Dilea Zanotto Manfio, Elias Tomé Saliba, Patricia Maria Artundo;

- Do Instituto de Estudos Brasileiros: às arquivistas Maria Helena P. Schiesari, Maria Izilda Claro do Nascimento Fonseca Leitão, Maria Cecília de Castro Cardoso, à bibliotecária Maria Itália Causin e equipe; a Lúcia Thomé, responsável pela conservação e restauro, e aos funcionários administrativos;

- Aos companheiros de estágio no IEB: Daniel, Vitor, Érica, Olívia, Klaus, Judi, Rodrigo e Rosângela, Paula, Cibele, Mônica, Érica, Wellington, Rosângela, Bibiane, Marjorie, Francine, Caio, Priscila, Vanessa, Jailson, Paulo, Pedro, Thiago, Alecs, Varney;

- João Carlos Zan, Nádia Regina Marques Coelho Bumirgh, Regina Freitas Fontes, Luís Antonio Matos, Flávia Takahashi Flores, Fernanda Magalhães, Sidney Pires, Luiz Lima Vailati, Maria Guadalupe Nogueira; Juliana Vernaglia; Amadeu Amaral, Isabel Cepeda;

- O apoio incondicional da família: meu irmão Antonio Jaschke Machado, meus pais Antonio Machado e Angela Jaschke Machado, e meu companheiro Rubens Leonardo Panegassi.

Esta pesquisa contou com apoio financeiro da Capes. 


\section{RESUMO}

Esta dissertação de mestrado tem como objetivo apresentar os documentos e determinadas perspectivas de estudo vinculadas à série Manuscritos de outros escritores MOE - que integra o Arquivo Mário de Andrade no Instituto de Estudos Brasileiros da Universidade de São Paulo.

A série reúne textos de poetas, ficcionistas e ensaístas brasileiros, bem como de alguns nomes estrangeiros, em versões que se apresentam em autógrafos, datiloscritos e impressos rasurados, abrangendo o período que vai do início dos anos 1910 a 1945, com exceção de um manuscrito da segunda metade do século XIX. Grande parte dos manuscritos guarda nas margens o esboço das impressões da leitura do autor de Macunaíma ou os primeiros passos da redação de críticas que mais tarde serão por ele publicadas. As notas marginais autógrafas configuram um diálogo intertextual que se estende até a correspondência ativa e passiva do crítico. Os Manuscritos de outros escritores, neste Catálogo analítico, são trabalhados no âmbito da historiografia literária, da codicologia e da crítica genética.

Palavras-chave: Mário de Andrade; Modernismo; manuscritos; correspondência; processos de criação.

\section{ABSTRACT}

The aim of this master's dissertation is to present documents and certain perspectives of study linked with Others writers manuscripts series (série Manuscritos de outros escritores - MOE) which integrates Mário de Andrade Archive in University of São Paulo Brazilian Studies Institute.

The series collects Brazilian poets, fictionists and essayists texts, as well as some foreign names, in versions presented in autograph, typewritten and crossed out printings, including the period from the beginning of the 1910's to 1945, except for a second half of the XIX century manuscript. Most of manuscripts keep Macunaima's author reading impressions draft in their margins or the first steps of the criticism writing that will be published by him later on. The autograph notes in the margins represents an intertextual dialog, which is expanded up to the active and passive critic's correspondence. In this Analytical catalog, the Others writers manuscripts are studied in the scope of literary historiography, codicology and genetic criticism. 


\section{SUMÁRIO}

1. Manuscritos de outros escritores no Arquivo

Mário de Andrade: perspectivas de estudo..................................................... 5

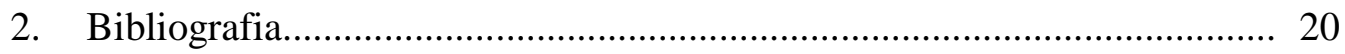

3. Série Manuscritos de outros escritores - MOE

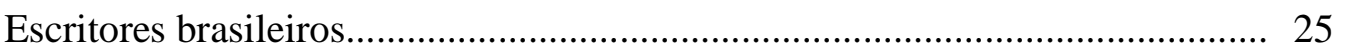

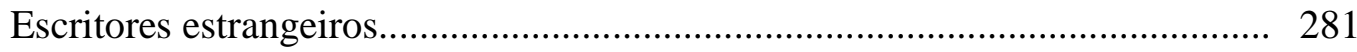

4. Índice dos nomes na série Manuscritos

de outros escritores Arquivo Mário de Andrade.............................................. 290 


\section{MANUSCRITOS DE OUTROS ESCRITORES NO ARQUIVO MÁRIO DE ANDRADE: PERSPECTIVAS DE ESTUDO}

Em 15 de setembro de 1942, Mário de Andrade escreve a Sérgio Buarque de Holanda, solicitando-lhe os manuscritos de Monções, ensaio de fôlego ao qual o historiador então se dedicava, visando apresentá-lo em um concurso nos Estados Unidos. Na carta se lê: "Concebi um desejo ousado. Vamos a ver se desta vez eu chego antes do Rodrigo". Como você deve saber, bibliófilo inveterado e sem vergonha como todos, tenho uma coleção de originais (manuscritos ou datilografados de primeira versão, corrigidos) que é uma já bonita coisa. Entre outras importâncias tem o 'Brás Bexiga e Barrafunda', o 'João Miguel' e ‘As Tres Marias' da Raquel, um Lins do Rego, um Marques Rebelo, um quarteto inédito do Henrique Oswald, etc etc. Já uns quarenta números sem contar as poesias está claro, Manuel, o Drummond o livro retirado do mercado do Murilo Mendes etc. Acresce que deixo tudo pro Estado, Biblioteca Municipal, não deixo pra família. Concebi a idéia de ter os originais, projetos, rascunhos, etc. do livro que você está escrevendo pro tal concurso nos States, é possível? Ficava numa vaidade danada, e havia de tomar um drinque bom em honra vossa. Mande contar se é possível, pra eu ficar me rindo todo". ${ }^{2}$

Mário colecionador, que assim se manifestava em 1942, novamente perdeu para Rodrigo Mello Franco de Andrade, outro grande amigo, a quem Sérgio Buarque de Holanda já prometera os manuscritos. As afinidades de Mário de Andrade com Rodrigo, como bem se vê, somavam o reconhecimento da importância da salvaguarda do patrimônio histórico e artístico do país à bibliofilia. A carta ao amigo historiador, contudo, registra, com tintas de testamento do homem público, um importante desejo: destinar ao Estado todo o material que lograsse coletar. Sabia do valor dos documentos de arquivos pessoais, enquanto fontes primárias do trabalho historiográfico; em 1944, focalizará diretamente o assunto no artigo "Fazer a história", na Folha da Manhã. Há muito tempo empenhava-se em reunir documentos que pudessem servir a futuros pesquisadores, ciente da importância

\footnotetext{
${ }^{1}$ Referindo-se a Rodrigo Mello Franco de Andrade, Diretor do Serviço do Patrimônio Artístico e Histórico Nacional, SPHAN.

${ }^{2}$ Documento no CEDAL, UNICAMP, no Arquivo Sérgio Buarque de Holanda.
} 
do período em que vivia: "Tudo será posto a lume um dia, por alguém que se disponha a realmente fazer a história", sentencia, então, em 1944. Fiel a seus propósitos de democratização da cultura, Mário nega o colecionismo particular, tantas vezes sujeito à imobilização fetichista. Mas, o que não imaginava, é que os manuscritos por ele coligidos, assim como todo o seu acervo, composto de biblioteca, arquivo e coleção de artes plásticas, em 1968 viria justamente integrar o patrimônio do Instituto de Estudos Brasileiros da Universidade de São Paulo, fundado por Sérgio Buarque de Holanda em 1962. No IEBUSP, o arquivo, sob a curadoria de Telê Ancona Lopez, nas séries que o constituem, vem sendo objeto de organização e difusão.

\section{Vertentes na coleção de manuscritos de outros escritores}

No segundo semestre de 1943 e no início de 1944, diversas entrevistas e reportagens celebraram os 50 anos de Mário de Andrade (nascido em 3 de outubro). Em duas delas os jornalistas desvelam, com entusiasmo, o espaço da casa da rua Lopes Chaves, dando destaque ao trabalho do intelectual e à riqueza de suas coleções. Mário da Silva Brito, no Diário de S. Paulo de 2 dezembro de 1943, assim se expressa:

"Decididamente cometi uma imprudência indo procurar Mário de Andrade para uma entrevista. É que ele, há já algum tempo, anda enfermo, necessitando de repouso e tranqüilidade, duas coisas que, jamais, um especula de jornal poderá ofertar. Era meu dever fazer-lhe apenas uma 'visitinha de médico'. Mas quem diz que fui capaz. Conversa puxa conversa, hora vem e hora vai, quando tive que dar 'boanoite!' - os ponteiros do relógio tocavam-me da sala - meu Deus do céu!, já tinha acontecido a inevitável e prevista imprudência. De quem a culpa? Minha, por ser curioso. Dos leitores, que querem notícias. De Mário de Andrade, em torno de quem sempre há um grande interesse.

'Devolvido o escritor ao seu merecido sossego, lá fui eu melancólico pelas ruas, os olhos ainda lembrados do ambiente acolhedor da casa de Mário: quadros de Portinari, de Segall e de Tarsila, pastas de artigos, revistas, álbuns 
de arte, recortes de jornal e mil e uma outras coisas. E um bem-estar com visgo."3

E Francisco de Assis Barbosa, repórter de Diretrizes, o secunda, em janeiro de 1944, percorrendo o sobrado onde vivia o escritor: "É uma casa simples, sem luxo. Mas está cheia de quadros, de livros, de músicas. Lhote, Picasso, Portinari, Segall. Sem falar na coleção de desenhos e gravuras, que sobem a oitocentos mais ou menos. E os livros? Há de tudo. A parte principal é sobre arte e literatura. As músicas estão embaixo, numa sala pequena, que tem o retrato de Beethoven. Sei que existem para mais de vinte mil peças, todas devidamente catalogadas na biblioteca Mário de Andrade". 4

Testemunhavam, os dois jornalistas, o esforço de uma vida inteira. Mário de Andrade devotado à tarefa de reunir documentos de seu tempo mostra-se, pela primeira vez, entre 1909 e 1910. Em um volume de contabilidade, certamente descartado pelo pai, contador do Conservatório Dramático e Musical de São Paulo, ele improvisou, aos 16 anos, um álbum de recortes. No volume encadernado em pano-couro preto, as folhas marcadas pelas colunas "Datas", "Deve" e "Haver", as páginas numeradas a carimbo, dispôs textos e imagens tirados de jornais e revistas dos anos referidos, discriminadas as áreas de filosofia, literatura, ciências, história universal, música, geografia, estatística, pintura e escultura. Colou na capa o cartão de visita: "Mário Raul, /Largo do Payssandú, 26, São Paulo", sobre o qual se lê, em letra floreada, o título A Batalha das Notas, seguido da assinatura "MRAndrade". Ao guardá-lo em seu arquivo, o moço e depois o intelectual consciente não permitiram que o tempo apagasse esse marco dos seus primeiros interesses no campo cultural de seu tempo e do seu gosto de colecionar. O álbum de recortes baliza o despertar, bem mais tarde rememorado para a discípula Oneida Alvarenga:

"Que mistério, que intuição, que anjo-da-guarda, Oneida, quando aos 16 anos e muito resolvi dedicar-me à música, me fez concluir instantaneamente que a música

\footnotetext{
${ }^{3}$ Entrevista de Mário da Silva Brito: "Trabalhos de Mário de Andrade. O mais organizado intelectual do Brasil”. Diário de S. Paulo. São Paulo, 2 dez., 1943. (Arquivo Mário de Andrade - IEB - USP).

4 Acusa Mário de Andrade: "Todos são responsáveis! Os intelectuais puros venderam-se aos 'donos da vida' Entrevista de Mário de Andrade a Francisco de Assis Barbosa, Diretrizes, a 4, n 184 . Rio de Janeiro, 6 jan., 1944, p. 1, 25, publicada em LOPEZ, Telê Ancona, org. ANDRADE, Mário de. Entrevistas e depoimentos. São Paulo, T. A. Queiroz/ FAPESP, 1979. O jornalista recolheu o texto em seu livro Testamento de Mário de Andrade e outras reportagens. Rio de Janeiro, Departamento de Imprensa Nacional, 1954, p. 8-9.
} 
não existe, o que existia era a Arte?... E desde então, desde esse primeiro momento de estudo real (antes, por uns meses apenas, estudara piano sozinho, só pra gastar o tempo), desde então, assim como estudava piano, não perdia concerto e olhava a vida dos músicos, também não perdia exposições plásticas, devorava histórias de arte, me atrapalhava em estéticas mal compreendidas, estudava os escritores e a língua, e, com que sacrifícios nem sei pois vivia de mesada miserável, comprava o meu primeiro quadro! Por sinal que, não caçoe, eram umas ninfeáceas roxas num lago, com um fundo de grandes árvores florestais, obra do Torquato Bassi! não caçoe, menina. Mas eu amei aquela água que parecia profunda mesmo.",

O álbum de recortes, posto ao lado da aquisição do primeiro quadro, anuncia o futuro colecionador de livros, manuscritos e obras de arte. Esse gosto lhe chegara no próprio ambiente familiar. O avô materno, Joaquim de Almeida Leite Morais, o pai que imprimia livros, o primo de Araraquara, 19 anos mais velho, Pio Lourenço Correa, a quem Mário chamava de tio. Este, em uma das cartas que endereçou a Mário de Andrade, datada de Araraquara, 11 de outubro de 1923, dá conta da presença de um exemplar do "grande Saint Hilaire", na biblioteca do avô. Nessa correspondência e em outras que se ligam ao escritor modernista, como nas que envolvem Sérgio Milliet, Sérgio Buarque de Holanda ou Murilo Miranda, desenha-se o colecionador e o bibliófilo.

Ao longo dos anos, vivendo em São Paulo, à rua Lopes Chaves, de 1922 até morrer em 25 de fevereiro de 1945, com exceção do período em que morou no Rio de Janeiro entre junho de 1938 e março do ano de 1941, Mário fez da casa, onde se radicou, o espaço do acervo. Pouco a pouco, os quadros tomaram as paredes; os cômodos se submeteram às necessidades do colecionador estudioso que buscava, cada vez mais, lugar para seus móveis de moderno design destinados a abrigar seus teres e haveres. ${ }^{6}$ Livros, partituras, esculturas, imagens de santos, objetos do folclore e relacionados à Revolução de 1932, bem como instrumentos musicais de índios, fotos, programas de concertos, desenhos infantis, fichários de pesquisas e leituras, manuscritos, correspondência traduzem, nesse acervo, o prazer da conquista do conhecimento e o trabalho.

\footnotetext{
${ }^{5}$ ALVARENGA, Oneida, org. Mário de Andrade - Oneyda Alvarenga: cartas, p. 270-271, carta a Oneida Alvarenga de 14 de setembro de 1940.

${ }^{6}$ Sobre o interesse de Mário de Andrade pelo design alemão, v. PAULA, Rosângela Asche de. "Mário de Andrade 'Designer' aprendiz”. Revista D. O. Leitura. São Paulo, Imprensa Oficial do Estado, no 3, ano 19, mar. 2001, p. 14-21.
} 
Aos olhos de quem transitava pela residência, descobria-se o acervo organizado segundo a lógica deste colecionador que conjugava o prazer de possuir ao de compartilhar, como se vê neste trecho da carta que endereçou a Paulo Duarte, em 23 de abril de 1943: "Neste momento em que lhe escrevo, 16 horas desta Sexta-Feira Santa, estou aqui cheio de universitários mineiros que vieram ver minhas coisas. Cada um está pra seu lado, mexendo em livro, lendo meus contos inéditos, mexendo na minha coleção de desenhos. São gente que veio pras Olimpíadas Universitárias e ando com a casa cheia de moços, dia e noite"7.

No que se refere aos manuscritos de outros escritores, a coleção tem início na segunda metade da década de 1910, movida possivelmente por um escopo de nuances fetichistas. Mário de Andrade adquire, nesse momento, Jacinto, o pequeno cesteiro, um conto para crianças da segunda metade do século XIX, na pena de Alexander Hummel, dinamarquês que viera morar no Brasil. Depois, em junho de 1919, quando faz sua primeira viagem às cidades históricas de Minas Gerais, tendo já publicado Há uma gota de sangue em cada poema, ao visitar Alphonsus de Guimaraens em Mariana, o encontro rende-lhe a preciosidade de um autógrafo do grande simbolista, Factum, bem como a cópia por ele assinada de Soneto, feita na hora pelo visitante. Este, ávido em sua admiração, copia ainda dois sonetos de Pauvre Lire, livro publicado em 1921. A esses textos a coleção soma dois outros cujo significado é único no universo do acervo que o autor de Macunaíma construiu. São aqueles que marcam a lembrança do pai, Carlos Augusto de Andrade, escritor bissexto, falecido em 1917: o poema "É certo? A teus pés prostrado" e a peça de teatro $A$ mão da caridade.

No início da década seguinte, em 1922, Mário de Andrade conhece o poeta Manuel Bandeira, com quem inicia uma amizade para toda a vida, retratada na extensa correspondência com ele trocada, na qual estão intermináveis discussões sobre a produção literária de ambos. Mário de Andrade e Bandeira são artistas que se encontram em um mesmo patamar, donos cada de seus respectivos projetos e caminhos. Cultivam o hábito de remeter um ao outro os textos em fase de criação, esperando o comentário sincero, a sugestão que, muitas vezes, muda o destino da escrita. Mário de Andrade colecionador vai assim agregando à ainda insipiente coleção, manuscritos que chegam para Mário de

\footnotetext{
${ }^{7}$ CAMARA, Cristiane Yamada. Mário na Lopes Chaves. São Paulo, Fundação Memorial da América Latina, 1996, p. 52.
} 
Andrade poeta, o qual, nesse período de efervescência modernista, pleno de experimentação, dialoga com outros pares seus, em São Paulo, no Rio e em Paris. Assim, recebe os originais de Cocktails, livro que Luís Aranha nunca publicou de motu próprio ${ }^{8}$, poemas que Tácito de Almeida deixaria inéditos, bem como as poesias Ronald de Carvalho que integrariam Jogos Pueris. Enquanto isso, da capital da França, Sérgio Milliet envia-lhe Cartões postaes e o aproxima de escritores de lá que também marcam presença com manuscritos, como Ivan Goll, poeta de Absolument, e Nico Horigoutchi, este ocupado com La poésie japonaise contemporaine e com a tradução de haikais para o francês. É interessante notar que o modernista brasileiro, ao receber os dois últimos textos, está se abrindo para essa nova forma de poesia que, naquela hora, entusiasmava o Ocidente. E, logicamente, expandindo o circuito do diálogo interpares nascido de sua amizade com Bandeira.

Mas é na segunda metade dos anos 1920 que a coleção dos manuscritos de outros escritores tem seu volume aumentado consideravelmente e ganha novo e importante traço vinculado, prioritariamente, à crítica literária como prática. Nessa época, o autor de Paulicéia desvairada é procurado por jovens poetas, admiradores seus de Belo Horizonte, como Francisco Martins de Almeida, Pedro Nava, João Alphonsus, e de Cataguases, no grupo organizado em torno da revista Verde, Rosário Fusco, Ascânio Lopes, Henrique de Rezende e Francisco Inácio Peixoto. Haviam entrado em contato com Mário de Andrade quando ele, na caravana da "viagem da descoberta do Brasil", estivera na capital mineira, e em Cataguases, assim como em outras cidades. Agora, isto é, a partir de 1925, dirigem ao amigo inquietações, textos e o constituem mentor. Mário, que há bastante tempo iniciara sua marginalia, ao apor seus comentários nas páginas dos livros de sua biblioteca, passa a redigir suas impressões de leitura e notas críticas nas margens dos manuscritos que recebe, esboços os quais, na maioria das vezes, vão estribar comentários com que orienta, em cartas, aqueles moços que se aventuravam nas plagas da literatura. Transfere, pois, esses comentários para cartas e para artigos que publica em jornais e revistas.

Neste ponto, nas relações de Mário mentor dos mineiros, surge uma situação importante: a de Carlos Drummond de Andrade, cujos primeiros manuscritos convalidam o

\footnotetext{
${ }^{8}$ O fato de Luís Aranha estar vivo em 1984 e ter autorizado a edição de Coctails, organizada por Nelson
} Archer e Rui Moreira Leite, não significa que ele, autor, tenha tomado essa iniciativa. 
mentor, mas, que, no crescer de sua poesia logo se equipara ao poeta de Clã do jabuti, na vertente do diálogo interpares da coleção.

Depois dos mineiros, muitos e muitos vieram, movidos pelo desejo de receber uma leitura correta no apontar enganos e possibilidades, capaz de confessar dúvidas e perplexidades como no caso dos contos de Murilo Rubião. É importante lembrar que, mesmo aceitando o trabalho de orientação severa, ligado à prática de crítico e correspondente pontual, Mário de Andrade recusa o rótulo de mentor. Quando escreve a Henriqueta Lisboa, em 24 de fevereiro de 1940, manifesta-se a respeito do assunto e distingue, inclusive, o proveito do crítico: "E agora sou eu que lhe peço me envie os versos que está fazendo. Não que eu me tenha por mentor de ninguém, mas porque sou seu amigo [...]. Pois nesta intimidade nem temerei ser pedante e lhe direi, com o máximo rigor, o que descobrir ou inventar nos seus poemas. Mas mande muitos, mande de novo os já mandados (pra me evitar o trabalho de procurá-los neste apartamento de barafunda) e muitos mais, o maior número que puder. O elemento comparação é imprescindivel num estudo e só mesmo tendo um grupo vasto de poemas, poderei compreender milhor. Mande e nem de longe receie me atrapalhar, sou eu que preciso de você". 9

À medida que se alastra pelo Brasil a difusão dos livros de Mário e que se multiplicam seus contatos com outros escritores, de outros estados brasileiros vão chegando trabalhos, pedindo leitura e orientação. Luís da Câmara Cascudo, além de aparecer na coleção como o poeta que poucos conhecem, apresenta a Mário os poemas de seu conterrâneo potiguar, Jorge Fernandes, o qual, também se corresponderá com o mentor. $\mathrm{O}$ Rio Grande do Sul comparece com a poesia de Augusto Meyer; Manuel Bandeira proporciona ao poeta Dante Milano a oportunidade de ser lido, nos manuscritos dele que faz chegar às mãos do amigo em São Paulo.

O diálogo interpares, nascido em 1922, expande-se quando nele ingressa a América do Sul, com a participação dos argentinos Bernardo Graiver e Marcos Fingerit, além do peruano Alberto Guillén. Sublinha o interesse de Mário por essa nova frente de interlocução. Intencionam ser divulgados entre os escritores daqui. Mário de Andrade, naquela época interessado na produção intelectual e artística dos países vizinhos, tenta o

\footnotetext{
${ }^{9}$ CARVALHO, Abigail de Oliveira (org.). Querida Henriqueta. Cartas de Mário de Andrade a Henriqueta Lisboa. Rio de Janeiro, José Olympio, 1991, p.3-4.
} 
papel de intermediário divulgando o trabalho, principalmente dos argentinos, para alguns poetas como Manuel Bandeira. ${ }^{10}$

Em 1930 chega ao acervo de Mário de Andrade, no bojo de um propósito diverso, a versão em autógrafo, os originais de Brás, Bexiga e Barra Funda. Quem a oferece não é um estreante, nem um companheiro de ofício que almeja a opinião do leitor rigoroso antes de ultimar a obra. Trata-se do reconhecimento de uma coleção, feito por Antônio de Alcântara Machado, o autor, quando entrega ao amigo e confrade modernista o manuscrito do livro publicado em 1927, atendendo ao pedido dele, pelo que se pode entender, com base na declaração na carta de 1942 a Sérgio Buarque. Neste autógrafo a tinta preta crivado de rasuras que testemunham, nas etapas de redação, o percurso da criação dos contos, não se vêem anotações da leitura do crítico, ao contrário de muitos outros manuscritos no arquivo dele. Os manuscritos nessa vertente reatam o elo com os primeiros momentos do colecionador e não são, como os que se instalam nas vertentes do mentor e do diálogo interpares, versões passadas a limpo. Não visam, de imediato, a leitura e conservam, na escrita despreocupada com o olhar de terceiros, o compromisso maior do criador com a própria escritura. Junto de Brás, Bexiga e Barra Funda alinham-se As Três Marias e João Miguel, de Raquel de Queiroz, Riacho Doce, de José Lins do Rego, A poesia de Jorge de Lima, do português Manuel Anselmo, A luz no sub-solo, de Lúcio Cardoso, O sinal de Deus, originais do livro de Murilo Mendes retirado do mercado ${ }^{11}$ e a peça de teatro Rua Alegre $n^{o} 12$, de Marques Rebelo. Henriqueta Lisboa, porém, ao passar a limpo em letra esmerada e encadernação cuidadosa, os poemas de A face lívida, para presente de aniversário do mentor que tanto prezava, não se desvia, com isso, dessa vertente; de modo indelével a acentua.

Na chave do colecionador, são agregados à coleção textos peculiares, como receitas de doces e um conto infantil da cultura popular, Maria Borralheira, enviados por Stella Gris, esposa do escritor pernambucano Ascenso Ferreira. E as receitas coligidas por Alcântara Machado, a do doce fudge, e pelo médico e escritor paraense Gastão Vieira, a de tacacá. Esses documentos corroboram as dimensões de Mário de Andrade pesquisador da

\footnotetext{
${ }^{10}$ Sobre esse tema V. ARTUNDO, Patricia Maria. Mário de Andrade y la Argentina. Tese de Doutoramento, São Paulo, Universidade de São Paulo, 2001, tomos I e II.

${ }^{11}$ O livro de Murilo Mendes foi retirado do mercado porque Adalgisa Nery, a musa do poeta, acabara de se casar com Lourival Fontes, o encarregado de redigir os discurso de Getúlio Vargas, no Estado Novo.
} 
cultura popular e de "gourmet". Na verdade, em termos de autoria, manuscritos desse naipe significam compilações norteadas por interesses afins aos do escritor. A chave do colecionador abrange também a pesquisa de Nicanor Miranda em 1937, sobre a classificação das idades infantil e juvenil, na qualidade de participante do projeto educacional dos parques infantis, coordenado por Mário de Andrade, então Diretor do Departamento de Cultura da Prefeitura da Municipalidade de São Paulo. Do mesmo modo, essa vertente acolhe o texto da fala radiofônica de Paulo Duarte na National Broadcasting Corporation de Nova Iorque, em fevereiro de 1942. Exilado do Estado Novo, o jornalista amigo e antigo companheiro do Departamento de Cultura, no programa que mantinha sobre livros brasileiros na NBC, ali focalizou Poesias, de Mário de Andrade.

Nos anos de 1940, a coleção dos manuscritos de outros escritores já apresenta as vertentes que atualmente a configuram. Nessa década, na verdade reduzida a cinco anos, pois Mário de Andrade morre em fevereiro de 1945, o conjunto cresce principalmente na parcela que contempla o mentor. Muitos são os moços que se dirigem ao escritor já consagrado. Dentre eles, destacam-se dois amigos mineiros inseparáveis, Hélio Pellegrino e Otto Lara Resende, ambos poetas, nesse momento ${ }^{12}$. E Henriqueta Lisboa, também mineira, que se torna grande amiga.

\section{$\underline{\mathrm{O} \text { sentido de uma coleção }}$}

Os manuscritos que Mário de Andrade salvaguardou, chegavam-lhe de maneiras distintas, a maioria encaminhada pelos próprios escritores, alguns por terceiros, sem contar os textos raros, que ele procurava obter. São datiloscritos, autógrafos e alguns impressos rasurados que, assim, se transformam em manuscritos. A maioria se apresenta com poucas rasuras, pois aqueles que vinham acompanhados do pedido de leitura, eram antes passados a limpo e, certamente, na releitura precedendo a cópia, no autógrafo ou no datiloscrito, recebiam correções a erros flagrados e transformações decorrentes de um novo momento na criação.

Representam, salvo as receitas culinárias e alguns registros da cultura popular, elos perdidos da criação literária, que tanto se ligam aos documentos de processo em uma

\footnotetext{
${ }^{12}$ Otto Lara Resende, aliás, se mostra, na série Manuscritos de outros escritores, com um poema redigido no Cassino da Pampulha e dedicado a Mário de Andrade.
} 
determinada obra, fora do âmbito da coleção, como se transmutam em parcelas desta. Como bem analisa Walter Benjamin, quando examina a questão das transferências, passam a pertencer a um novo espaço em outro universo, o da coleção. ${ }^{13}$ Paralelamente, segundo Benjamin, com exceção dos livros - dos manuscritos, acrescentamos -, todos os objetos quando colecionados, perdem o seu valor de uso e ganham uma nova significação; podem, mesmo, ser vistos como souvenirs. No caso de xícaras coletadas em viagens, por exemplo, pois elas deixam de ser o recipiente onde se bebe líquidos; não entram em armários de cozinha, mas são expostas em estantes. Com os livros, segundo o filósofo, isso não ocorre, pois independente de se apresentarem ou não como souvenir, não perdem o valor de uso, continuam servindo à leitura. ${ }^{14}$ Nesse sentido, os manuscritos de outros escritores coletados por Mário de Andrade, perdem apenas em parte o seu valor de uso. Nas estantes do crítico e colecionador, separam-se do dossiê primordial da criação de um determinado texto, e não são mais alcançados pela vontade de quem os produziu. Poetas, ficcionistas e ensaístas não podem mais interferir naquele texto que é de sua lavra, mas que dela se distancia fisicamente enquanto documento específico. A partir do momento em que aportam à coleção, os manuscritos ficam a mercê do colecionador que os transforma em objeto do prazer do seu olhar, da sua leitura ou, no caso de Mário de Andrade, de seu trabalho de crítico literário. Assim se passa com boa parte dos manuscritos conservados por Mário que, nas modificações nascidas de sua leitura de crítico e sugeridas aos autores nas notas marginais, em geral a lápis, transformava ele próprio os textos alheios; tornava-os diferentes, outros, atuando como co-autor, à revelia ou com pleno consentimento de quem o procurava. Um excelente exemplo disso está na capa que Mário desenha para Cocktails de Luís Aranha, depois de ler, comentar e sugerir uma ordem para os poemas no livro pretendido.

Além disso, na esfera da crítica genética, conclui-se que as observações de Mário de Andrade nas margens dos manuscritos (otas MA) apresentam-se, em vários casos, como notas prévias de artigos ou cartas por ele remetidas aos escritores. Assim, pode-se lembrar que, nos poemas recebidos de Luís Aranha em 1921-1922, estão observações oriundas de

\footnotetext{
${ }^{13}$ Bernard Vouilloux também trata desse assunto no artigo "Discurs du collectionneur, discurs de la collection au XIX siècle", na Poetique Revue de theorie et d'analyse litteraries, no. 127 (Paris, Seuil, septembre 2001).

${ }^{14}$ BENJAMIN, Walter. "The Collector". In: The arcades project. $3^{\mathrm{a}}$ ed. Translated by Howard Eiland and Kevin McLaughlim. The Belknap Press of Harvard University Press, 2002.
} 
uma leitura atenta, como a que se mostra na margem superior de "Minha amada": "Não ha rapidez nenhuma que elimine aqui o te. Cui- | dado! É preciso saber sempre onde canta o galo. E tu, que desempenhas pelos teus livros as cataractas, insecáveis helas!, dos | teus pronomes, artigos e pendu- | ricalhos indecentes, bem podes | aumentar aqui o te que falta". No cotejo dessas notas marginais autógrafas com o texto do artigo publicado em 1932, "Luiz Aranha ou a poesia preparatoriana", dez anos depois e efetivamente transforma seus comentários em notas prévias. Nessa ocasião, aproveita elementos da análise realizada e apóia o artigo em trechos dos poemas que, em 1932, destaca com traços a lápis vermelho à margem e a indicação "citar”, os quais aparecem, de fato, transcritos na versão que saiu na Revista Nova. Dentre os comentários esboçados em 1922, reelaborados no artigo, pode-se trazer este: "Me envaideço mesmo de ter de alguma forma provocado o aparecimento do Luís Aranha original. O maltratava com uma crítica exasperada que não perdoava senões, e blagueava, desprezando, sobre o excesso de 'uns' e possessivos gálicos nos versos dele”. Quanto às cartas, um bom confronto entre as notas marginais nos manuscritos e os textos que seguiram para os destinatários, desvendará, por certo, a natureza de textos fragmentários prévios dos comentários críticos esboçados durante a leitura de Mário de Andrade. Tal confronto está fadado a excelentes resultados, se tomar os manuscritos de Carlos Drummond, Manuel Bandeira, Henriqueta Lisboa, Alphonsus de Guimaraens Filho, Oneida Alvarenga, entre outros, e as cartas que receberam do correspondente contumaz.

É possível adiantar essa possibilidade ao considerar, no autógrafo do poema de Manuel Bandeira "Quando minha irmã morreu"16 que exibe, à margem do verso "veio para ao pé de mim", a nota a lápis preto de Mário de Andrade: "Paraopeba". Nota solitária, ganha sentido na carta que ele escreveu para Bandeira, de São Paulo, possivelmente antes de 13 de setembro de 1925: “'Quando minha irmã morreu'. Outra delícia silenciosa. Só não gosto daquele 'para ao pé' que você botou, talvez para evitar a repetição de 'para junto' que vem dois versos depois. 'Para ao pé' é horrível. Deve de ser lusitanismo. É feio em si e lembra paraopeba. Mude isso, porém cuidado em não perder o agudo 'mim' acabando o

\footnotetext{
15 "Luís Aranha ou a poesia preparatoriana" (Revista Nova, $\mathrm{n}^{\circ}$ 7, 1932), também publicado em Aspectos da literatura brasileira (Rio de Janeiro, Americ= Edit., 1943).

${ }^{16}$ O poema foi publicado com o título "O Anjo da Guarda" em Libertinagem (Rio de Janeiro, Paulo, Pongetti\& C., 1930).
} 
verso". Em 1930, na $1^{\text {a }}$ edição de Libertinagem, o poema aparece com o verso refeito: "Veio ficar ao pé de mim".

Os manuscritos de outros escritores ligam-se, portanto, à correspondência e à biblioteca. Nesse sentido, constroem a trama do acervo, a ser descoberta ou recomposta pelo pesquisador que precisa dela para compreender correlações e traçar hipóteses que tentem preencher lacunas na documentação e no tempo.

Ao focalizar a trama do acervo, vale recorrer às anotações marginais - Notas MA nos manuscritos de Oneida Alvarenga, a qual, aos 19 anos, em 1931, se torna aluna de piano de Mário de Andrade. A inclinação para literatura que a garota demonstra chama a atenção do professor que passa a orientá-la e a lhe pedir exercícios poéticos. Ela lhe entrega, então, a série de poemas Elogio da vida, a qual, já no título, é objeto de protesto veemente na nota a lápis preto na margem do manuscrito: "Elogio da Vida | (é horrivel. | 'A menina boba' 'A menina louca' | 'Potranca' não ter medo | das palavras fortemente objeti- | vas. São as que mais dão a | sensação nova. E pro | poema, o titulo tem | que ser vivaz”. Em 1938, depois de muitas idas e vindas para a leitura do mentor, na capa do livro ficará $A$ Menina Boba (São Paulo, Empresa Gráfica da Revista dos Tribunais). Durante os sete anos que separam o primeiro encontro da jovem com seu mestre de piano, de música, de literatura e de vida, muitas cartas levam a ele os poemas e são respondidas com sugestões que ampliam, de forma didática, as anotações marginais do crítico. A maioria dessas sugestões é levada em conta na versão publicada. No exemplar de A Menina Boba na biblioteca, a dedicatória confirma, por assim dizer, os caminhos do trabalho que cerca esta coleção de manuscritos: "Mario | com a minha mais per- | feita amizade e minha imensa | gratidão, guarde este livro | que é seu. | Oneyda. | 18-V-1938”.

Tanto no diálogo interpares quanto na relação dos escritores com o mentor, presenciase a co-autoria virtual. No caso de Oneida Alvarenga, Breno Accioly, Alphonsus de Guimaraens Filho, Henriqueta Lisboa, na vertente da interlocução com o mentor, e no de Manuel Bandeira, Sérgio Milliet, Drummond, entre outros, a questão da colaboração na criação surge com muita riqueza e sempre demanda o confronto com as obras publicadas ou versões posteriores àquelas remetidas a Mário de Andrade. Entretanto, esses laços entre versões no manuscrito, cartas e versões publicadas não esgotam as interrogações sobre co- 
autoria virtual. Esta alimentada também do diálogo implícito com a obra publicada de Mário, tomada como norte e matriz por muitos escritores.

O colecionador, mentor e interlocutor de seus pares certamente compreendeu que, além de preservar uma importante parcela da memória de seu tempo, reunia um testemunho significativo dos processos de escritura, bem como dos suportes e meios da escrita de muitos nomes da literatura, que, na verdade, protegia do esquecimento os bastidores da criação que mostram mais do que os livros, o estilo de sua época, o arte-fazer daquele período. Seu conjunto de manuscritos de outros autores, do mesmo modo que todos os demais conjuntos documentais de seu arquivo, uma vez transpostos para o patrimônio do Instituto de Estudos Brasileiros, mediante a doação, por parte da Família Mário de Andrade, vinculada à aquisição das outras parcelas do acervo do escritor, biblioteca e coleção de artes visuais, feita pela Universidade de São Paulo, em 1968, para o referido Instituto, sofreu mudança em sua natureza e função. Ao ingressar na esfera dos bens públicos, afastando-se da propriedade particular, passou a receber tratamento arquivístico destinado a disponibilizar os documentos para consulta no Setor de Arquivos no IEB. Como os demais conjuntos, tornou-se uma série do Arquivo Mário de Andrade, cuja organização se liga a projetos coordenados pela curadora, Prof ${ }^{a}$. Telê Ancona Lopez. Procurando sempre a função dos documentos e respeitando a teia de relações que constitui um arquivo e um acervo, esta organização trabalha o processamento das séries e a divulgação de seus conteúdos. Como destaca Bernard Vouilloux em seu texto "Discurs du collectionneur, discurs de la collection au XIX siècle"17, as ações de organização de salvaguarda conferem às coleções novos rumos e novos sentidos.

\section{$\underline{\text { Um catálogo analítico }}$}

No processo de organização do Arquivo Mário de Andrade para consulta, coordenado pela Prof ${ }^{a}$. Telê Ancona Lopez no IEB-USP, a série Manuscritos de outros escritores recebeu uma classificação prévia que identificou e ordenou sumariamente os documentos, contando com o trabalho das estagiárias Teresa de Almeida Arco e Flexa, Flávia de Oliveira Nunes e Ivani Cristina Silva Fernandes. Faltava, porém, uma nova classificação que, além de rever a primeira parcela realizada, pudesse compreender o

\footnotetext{
${ }^{17}$ VOUILLOUX, Bernard. Op. cit.
} 
material como reflexo de determinados aspectos da trajetória intelectual de Mário de Andrade, classificação associada a uma análise detida, atenta à tarefa de sanar lacunas e apta a desenvolver notas explicativas de cunho historiográfico, bem como breves estudos genéticos, já que se inclina sobre manuscritos da criação literária. Em suma, capaz de produzir o chamado catalogue raisoné, ou seja, um catálogo analítico, juntando a arquivística e a codicologia à pesquisa historiográfica no âmbito da Literatura Brasileira, enriquecida com recursos da Crítica Genética que tanto contribuem para a crítica literária. Um catálogo analítico que supõe, logicamente, o estudo das relações de Mário de Andrade com os documentos da coleção que ele reuniu.

Deste modo, o Catálogo analítico da série Manuscritos de outros escritores, no Arquivo Mário de Andrade, decorreu de metodologia vinculada à formação no mestrado, a qual tanto contemplou a rigorosa classificação de cunho arquivístico (identificação, ordenação, análise documentária, reprodução fac-similar dos documentos por meio de "scanner" (não concluída), e arranjo material) e transcreveu as notas deixadas pelo crítico nas margens dos manuscritos (Notas MA), como desenvolveu, nas notas de pesquisa e em uma breve abordagem genética, a análise historiográfica e genética dos documentos. Nesse sentido, abre perspectivas para novos estudos.

O catálogo procura compreender cada título nas vertentes da série que dizem respeito à natureza e à proveniência dos manuscritos, o que implicou também a análise das relações de Mário de Andrade com um elenco de escritores seus contemporâneos, consagrados ou estreantes. A análise forneceu à pesquisa três vertentes principais, discriminadas nas Notas de pesquisa:

Mário de Andrade colecionador - (Mac) - que parte do prazer individual da posse e evolui para a responsabilidade da partilha democrática quando o colecionador determina que os documentos sejam confiados a uma instituição pública. Nesta vertente, Mário de Andrade recolhe tanto obras raras e antigas como originais de obras de seu tempo, além de arrebanhar documentos de pesquisa de terceiros que vinham ao encontro de interesses seus de estudioso da cultura popular brasileira;

Mário de Andrade no diálogo interpares - (MAd) - que prende a interlocução com escritores contemporâneos de seu mesmo porte artístico, do Brasil e de outros países, vertente na qual aparece a importante questão da co-autoria virtual; 
Mário de Andrade mentor - (MAm) - quando reflete uma pedagogia da escritura literária decorrente do ofício do crítico, voltada para os escritores estreantes que procuravam o artista consagrado.

A transcrição diplomática da maior parte das notas autógrafas de Mário de Andrade, apostas aos manuscritos - Notas MA -, vale como divulgação de fragmentos críticos inéditos do escritor. 


\section{BIBLIOGRAFIA}

ALMEIDA, Benedicto Pires de. Cronologia tieteense, v. 1-2. Tietê, Mileni Editora, 1980.

ALVARENGA, Oneyda Alvarenga (org.). Mário de Andrade - Oneyda Alvarenga: cartas. São Paulo, Duas Cidades, 1983.

ANDRADE, Mário de. Aspectos da literatura brasileira. $5^{\text {a }}$ ed. Rio de Janeiro, Livraria Martins Editora, 1974.

O turista aprendiz. Estabelecimento de texto, introdução e notas de Telê Porto Ancona Lopez. São Paulo, Livraria Duas Cidades / Secretaria da Cultura, Ciência e Tecnologia, 1976.

- Táxi e crônicas no Diário Nacional. Estabelecimento de texto, introdução e notas de Telê Porto Ancona Lopez. São Paulo, Duas Cidades/ Secretaria da Cultura, Ciência e Tecnologia, 1976.

. Vida literária. Pesquisa, estabelecimento de texto, introdução e notas de Sonia Sachs. São Paulo, Hucitec/Edusp, 1993.

ANTELO, Raúl. Na ilha de Marapatá (Mário de Andrade lê os hispano-americanos). São Paulo, Hucitec, 1986.

ARTUNDO, Patricia Maria. Mário de Andrade y la Argentina. Tese de Doutoramento, São Paulo, Universidade de São Paulo, 2001, tomos I e II.

BARBOSA, Francisco de Assis. "Mário de Andrade: 'Os intelectuais puros venderam-se aos donos da vida"'. In: Testamento de Mário de Andrade e outras reportagens. Rio de Janeiro, Os cadernos de cultura / Ministério da Educação e Cultura.

BARBOSA, João Alexandre. "Método \& método". In: Opus 60. Ensaios de crítica. São Paulo, Duas Cidades, 1980.

BARTHES, Roland. Mitologias. $7^{\mathrm{a}}$ ed. Tradução de Rita Buongermino e Pedro de Souza. São Paulo, Editora Bertrand Brasil - Difel, 1987.

BATISTA, Marta Rosseti. Coleção Mário de Andrade: religião e magia, música e dança, cotidiano. São Paulo, Editora da Universidade de São Paulo / Imprensa Oficial do Estado, 2004.

et alii, org. Brasil; $1^{o}$ tempo modernista - 1917/1929. São Paulo,

Instituto de Estudos Brasileiros-USP, 1972. 
e LIMA, Yone Soares de. Coleção Mário de Andrade: artes plásticas. 2a ed. São Paulo, Instituto de Estudos Brasileiros, 1998.

BENJAMIN, Walter. "Historia y coleccionismo: Eduard Fuchs". In: Discursos interrumpidos I. Prólogo, tradução e notas de Jesus Aguirre. Madrid, Taurus, 1973. . "The Collector". In: The arcades project. $3^{\mathrm{a}}$. ed. Translated by Howard Eiland and Kevin McLaughlim. The Belknap Press of Harvard University Press, 2002.

BIBLIOTECA NACINAL DE LISBOA. Leituras: Arquivística literária e Crítica textual. Revista da Biblioteca Nacional, no 5. Lisboa, outono, 1999.

BIBLIOTHÈQUE LITTÉRAIRE JACQUES DOUCET. Paul Claudel: Premières Oeuvres 1886-1901. (manuscrits - inèdits - éditions originales). Préface de François Mauriac. Paris, Université de Paris, 29 novembre - 23 décembre, 1965.

BORGES, Jorge Luis. "Ulrica”. In: O livro de areia. Tradução de Lígia Morrone Averbuck. São Paulo, Editora Globo, 2001.

BOSI, Alfredo. "O movimento modernista de Mário de Andrade". In: Literatura e Sociedade. $n^{\circ}$ 7. São Paulo, FFLCH/USP, p. 296-301, 2003/2004.

BRITO, Mário da Silva. História do modernismo brasileiro: Antecedentes da Semana de arte moderna. $6^{\text {a }}$ ed. Rio de Janeiro, Civilização Brasileira, 1997.

CAMARA, Cristiane Yamada. Mario na Lopes Chaves. São Paulo, Fundação Memorial da America Latina, 1996.

CAMARGO, Eduardo Ribeiro dos Santos. Os Novaes de São Paulo. $2^{\mathrm{a}}$ ed., São Paulo, 1966.

CARVAlHO, Abigail de Oliveira (org.). Querida Henriqueta: Cartas de Mário de Andrade a Henriqueta Lisboa. Revisão, introdução e notas de Pe. Lauro Palú, transcrição dos manuscritos: Rozani C. do Nascimento. $2^{\mathrm{a}}$ ed. Rio de Janeiro, José Olympio, 1991.

CASTELLO, José Aderaldo. A literatura brasileira: origens e unidade (1500-1960), v. 2. São Paulo, Editora da Universidade de São Paulo, 1999.

COUTINHO, Afrânio e SOUZA J. Galante de. Enciclopédia de literatura brasileira. 2 v. Rio de Janeiro, Fae, 1990. 
FOUCAULT, Michel. O que é um autor?. Tradução de Fernando António Cascais e Edmundo Cordeiro. 2a ed. [s.1.], Passagens, 1992.

FROTA, Lélia Coelho (org. e pesquisa icinográfica). Carlos \& Mário: Correspondência completa entre Carlos Drummond de Andrade e Mário de Andrade. Prefácio e notas de Silviano Santiago. Rio de Janeiro, Bem-te-vi, 2003.

GANDELMAN, Claude. Le regard dans le texte. Paris, Méridiens-Klincksiec, 1986.

GRÉSILLON, Almuth. Eléments de critique génétique. Paris, Presses Universitaires de France, 1994.

GUIMARAENS FILHO, Alphonsus de (org.). Itinerários: cartas a Alphonsus de Guimaraens Filho. São Paulo, Duas Cidades, 1974. Poemas reunidos. Rio de Janeiro, Livraria José Olympio Editora, 1960.

HERSCHBERG-PIERROT, Anne. Répertoire des manuscrits littéraires français XIXe XXe siècles. Paris, Bibliothèque Nationale Departement des Manuscrits, 1985.

HOLANDA, Sérgio Buarque de. "Poesia e crítica". In: O espírito e a letra I. São Paulo, Companhia das Letras, 1996.

INSTITUTO DE ESTUDOS BRSILEIROS. ABC do IEB: guia geral do acervo. São Paulo, Edusp / IEB, 1997.

KAZ, Leonel, LOPEZ, Telê Ancona e MONTEIRO, Salvador. A imagem de Mário; fotobiografia de Mário de Andrade. Rio de Janeiro, Alumbramento / Livroarte Editora, 1998.

LAFETÁ, João Luiz. 1930: A crítica e o modernismo. $2^{\mathrm{a}}$ ed. São Paulo, Livraria Duas Cidades / Editora 34, 2000.

LARA, Cecília de. Comentários e notas à edição fac-similar de 1982 de Brás, Bexiga e Barra Funda. São Paulo, Convênio Imprensa Oficial do Estado de São Paulo e Divisão de Arquivo do Estado de São Paulo, 1982.

LIMA, Yêdda Dias e REIS, Zenir Campos, (coords.). Catálogo de manuscritos do Arquivo Graciliano Ramos. São Paulo, Edusp, 1992.

LOPEZ, Telê Porto Ancona Lopez. "A bagagem poética do turista aprendiz". In: Mariodeandradiando. São Paulo, Hucitec, 1996. 
(org.). Entrevistas e depoimentos. São Paulo, T. A. Queiroz,

1983.

(org.). Manuel Bandeira: verso e reverso. São Paulo, T. A. Queiroz,

Editor, 1987.

Mário de Andrade: Ramais e caminho. São Paulo, Livraria Duas

Cidades, 1972.

MORAES, Marcos Antonio de e SANTOS, Tatiana Maria Longo do. Catálogo eletrônico da série Correspondência de Mário de Andrade. Instituto de Estudos Brasileiros - USP. Catálogo disponível no site: www.ieb.usp.br.

MACHADO, Antônio de Alcântara. Brás Bexiga e Barra Funda. Edição fac-similar anotada de Cecília de Lara. São Paulo, Convênio Imprensa Oficial do Estado de São Paulo e Divisão de Arquivo do Estado de São Paulo, 1983.

MELLO, Luís Correia de. Dicionário de autores paulistas. São Paulo, Comissão do IV centenário da cidade de São Paulo, 1954.

MELlO E SOUZA, Antonio Cândido de. "A revolução de 1930 e a cultura". Novos estudos, v. 2, n 4. São Paulo, Cebrap, p. 27-36, abril/1984.

“Literatura e cultura de 1900 a 1945”. In: Literatura e sociedade. São Paulo, PubliFolha sob licença de T. A. Queiroz, 2000.

MELLO E SOUZA, Gilda de. “'O Banquete””. In: O Baile das quatro artes. São Paulo, Livraria Duas Cidades, 1980.

e CANDIDO, Antonio. "A lembrança que guardo de Mário". Revista do Instituto de Estudos Brasileiros, no 36. São Paulo, Instituto de Estudos Brasileiros, 1994, p. 9-25.

MENEZES, Raimundo de. Dicionário literário brasileiro. Rio de Janeiro, Livros Técnicos e Científicos, 1978.

MORAES, Marcos Antonio de (org., introd. e notas). Correspondência Mário de Andrade \& Manuel Bandeira. $2^{\mathrm{a}}$ ed. São Paulo, Edusp / IEB, 2001.

Mário e o Pirotécnico Aprendiz: cartas de Mário de Andrade e Murilo Rubião. Belo Horizonte / São Paulo, Editora UFMG / IEB / Editora Giordano, 1995. 
"O orgulho de jamais aconselhar”: (A epistolografia de Mário de Andrade e seu projeto pedagógico). Tese de doutoramento. São Paulo, Universidade de São Paulo, 2002.

PAULA, Rosângela Asche de. "Mário de Andrade 'designer' aprendiz". D. O. Leitura, a. 19, no 3. São Paulo, Imprensa Oficial do Estado, mar. 2001.

PERES, Fernando da Rocha (org.). Correspondente contumaz : cartas a Pedro Nava, 1925 1944. Rio de Janeiro, Editora Nova Fronteira, 1982.

SALLES, Cecilia Almeida. Crítica genética: uma (nova) introdução. São Paulo, Educ, 2000.

SCHWARTZ, Jorge. Las vanguardias latinoamericanas. México, Fondo de Cultura Económica, 2002.

VEYNE. Paul. "O objeto da história”. In: Como se escreve a história e Foucalt revoluciona a história. $4^{\mathrm{a}}$ ed. Brasília, Editora da Universidade de Brasília, 1998.

VOUILLOUX, Bernard. "Discurs du collectionneur, discurs de la collection au XIX siècle”. Poetique: Revue de theorie et d'analyse litteraries, $\mathrm{n}^{\circ}$ 127. Paris, Seuil, septembre 2001.

WILLEMART, Philippe. Bastidores da criação literária. São Paulo, Fapesp / Iluminuras, 1999. Universo da criação literária. São Paulo, Edusp, 1993.

ZULAR, Roberto, (org.). Criação em processo: ensaios de crítica genética. São Paulo, Iluminuras / Capes / Fapesp, 2002. 
SÉRIE MANUSCRITOS DE OUTROS ESCRITORES - MOE ARQUIVO MÁRIO DE ANDRADE - IEB - USP

ESCRITORES BRASILEIROS 


\section{MA - MOE, 01}

ABREU, Rodrigues de (Benedito Luís Rodrigues de Abreu 1897-1927)

01. Casa destelhada; S Paulo; poesia (MAm)

São José dos Campos, 5 dez. 1925

Poemas enviados por RoA a MA no corpo da carta datada de "SJosé dos Campos, 5/12/25"; assinada: "Abreu."; forma de tratamento: "Meu caro Mario de Andrade:"; autógrafo a tinta azul; papel branco; 4 folhas (aparas); 33 x $12 \mathrm{~cm}$; vincos; sinais de fungo; folhas numeradas pelo escritor: 2-4; rasuras a tinta azul nos dois poemas; escrita no anverso; fólios numerados pela pesquisa: (1)-(4).

(Ref. cruzada: série Correspondência Mário de Andrade - sub-série Correspondência passiva; MA-C-CPMVA, $\mathrm{n}^{\circ}$ 17)

\section{Anexo:}

Envelope MA para acondicionar o ms: papel branco; 15,5 x 12,3 cm; fólio numerado pela pesquisa: (1).

Nota MA a lápis preto: "Rodrigues de Abreu".

Notas da pesquisa:

1. Ms na vertente Mário de Andrade mentor.

2. Em 23 de dezembro de 1924, a primeira carta a MA é acompanhada do exemplar do livro de estréia de Rodrigues de Abreu, A sala dos passos perdidos (São Paulo, Monteiro Lobato, 1924), que está na biblioteca MA, no IEB-USP, com a dedicatória: "A Mario de Andrade | com admiração | Rodrigues de Abreu | Campos do | Jordão | XII-1924".

(Ref. carta 23 dez. 1924: série Correspondência Mário de Andrade - sub-série Correspondência passiva; MA-C-CPL, $\mathrm{n}^{\circ}$ 9)

3. Desse primeiro contato epistolar nasceu a amizade interrompida pela morte de RoA, em 1927.

4. Na carta de 5 de dezembro de 1925 , acima registrada, está o pedido de RoA a MA: "Ahi vão uns versos pra você | dar a opinião:".

5. Os dois poemas saíram em Casa destelhada, São Paulo, Editorial Helios Ltda., 1927.

6. No ano de sua morte, junto com a última carta, em 7 abr. 1927, RoA encaminhou a MA um exemplar de Casa destelhada, com a dedicatória: "Pro Mario de | Andrade, com | admiração e | amor | Rodrigues de Abreu | S. Josè dos Campos | 2-4-27”. (Ref.: série Correspondência Mário de Andrade - sub-série Correspondência passiva; MA-C-CPL, $\left.\mathrm{n}^{\circ} 19\right)$.

7. Casa destelhada entrou na resenha de MA "Livros e livrinhos", publicada no Diário Nacional, São Paulo, em 25 out. 1927.

8. MA enviou a RoA o ms de seu poema "Sambinha", publicado em Clã do Jaboti dois anos depois, como se depreende da carta que, em 10 de setembro de 1925, o autor de Casa destelhada lhe endereça, desculpando-se pela demora em responder a missiva que acompanhara o poema. (Ref.: série Correspondência Mário de Andrade - sub-série Correspondência passiva; MA-C-CPL, $\mathrm{n}^{\circ}$ 15) 
Estudo genético:

1. No arquivo MA os poemas se apresentam-se em uma única versão, A, passada a limpo, no autógrafo que mostra 2 etapas na escritura: $\mathrm{a}-\mathrm{a}_{1}$ :

a: autógrafo completo;

$\mathrm{a}_{1}$ : rasuras autógrafas a tinta azul.

2. A versão $A$ confrontada com a versão impressa, $B$, na da $1^{a}$ edição de $A B R E U$, Rodrigues de. Casa destelhada (ed. cit.), mostra variantes.

\section{MA - MOE, 02}

ACCIOLI, João (João Batista Gonçalves Accioli 1912 - ?)

02. As sete palavras; poesia (MAm)

[São Paulo] s/d

Volume manufaturado como livro; datiloscrito, cópia carbono roxo; encadernado; capa dura em papel artesanal marmorizado com nuances de vinho e rosa; 26,8 x 20,8 cm; etiqueta vermelha colada no verso da quarta-capa: "ENCADERNADORA |ELO | TEL. 3-2391 - S. PAULO"; lombada de percalux vermelho, com autoria estampada por máquina em dourado: "JOÃO ACCIOLI - AS SETE PALAVRAS"; folhas de guarda em papel cinza com fibras no acabamento; $26,1 \times 20,2 \mathrm{~cm}$; miolo em papel branco, tipo seda; 50 folhas; $26,1 \times 19,4 \mathrm{~cm}$; sinais de fungo; folhas numeradas pelo escritor: $2-5$, 5a-40; escrita no anverso; rasuras a máquina e a tinta preta; f. 2: identificação de autoria e endereço: autógrafo a tinta preta: "João Accioli | R. Senador Feijó - 176 - 30"; fólios numerados pela pesquisa: (1)-(5) (2).

O ms apresenta os poemas em 3 partes: $1^{\text {a }}$ parte: "O cantico da hora presente" (f. 3-11), reunindo os títulos: Pórtico, As sete palavras, Os meus ipês, Mulher, Nos campos da Flandres, Mar, Noturno, Agonia, Serenata, Sombra, Vento, Primavera; $2^{\mathrm{a}}$ parte: "Eu" (f. 12-37), com os títulos: Tedio, Profissão de fé, Indiscrição, Domingo, Morte, Vida, Encantamento, Morte, Abril, Uma demagogiazinha, Enterro, Folhas, Si eu morresse amanhã..., Penumbra de bar, Petição, Cemiterio; e $3^{\text {a }}$ parte: "O elogio dos simbolos" (f. 38-49), com os títulos: Finados, Natal, Gramática, Filosofia, Repartição, Cega, Arvore, Palhaço, Natureza morta, A canção de amanhã.

Notas da pesquisa:

1. Ms na vertente Mário de Andrade mentor.

2. Não há cartas de JC no arquivo MA.

3. Os poemas Pórtico, As sete palavras, Os meus ipês, Mulher, Mar, Noturno, Agonia, Serenata, Sombra, Vento, Primavera, Tédio, Indiscrição, Domingo, Morte, Vida, Encantamento, Abril, Uma demagogiazinha, Enterro, Fôlhas, Si eu morresse amanhã, Penumbra de bar, Cemitério, Finados, Natal, Gramática, Filosofia, Repartição, Cega, Arvore, Palhaço, Natureza morta e A canção de amanhã foram publicados em $A$ canção de amanhã (São Paulo, Editora Brasiliense, 1948). 
Rua Sitonio Sais, $22 \not A$. Syoré dos Campes, $5 / 12 / 25$ Men caro macio de tudrade:

Me lencerei muito de vaie enter dias. Con vandade. Ponfue andei lendo attentanente (trelendo que $e^{\prime}$ ) a Gerava que иало é Kavera. Kua.

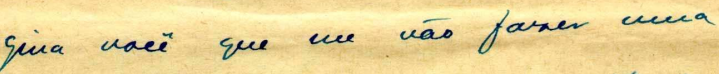
festa en Canquinas, con o fits de ue arranjacen uns cobrer. Prino we convidaran pa faxer nua confencia sobre on "Moderwitas Garileirs." Veja vó. Ine, atraradrie, им apenas "scirceranecte ceciono eraner sobre nodencisa cranlewis Váe aeneira, burrice ua secta. Nea, cono nào é coisa de houra, como nà vore bancar hiteratice - sin defender houertanente a vida, épejar e nào larfa. Q m. Caelko nettr e maction - Tonter fazen conferencias. E en vou ser houerto pupup nas falacei da acte modena, mas da micha admiracar pela equitis novos. Ena abrinacas porro-a dizer de qualquer geits, nat é? 


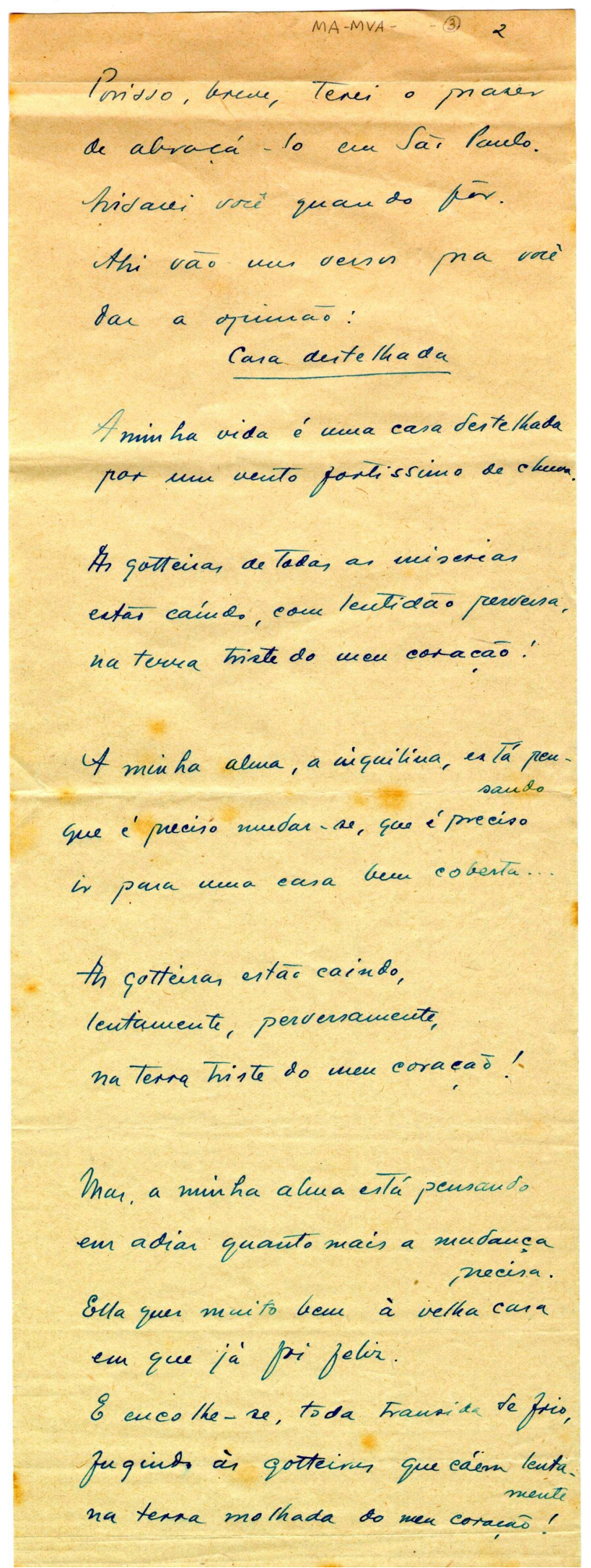




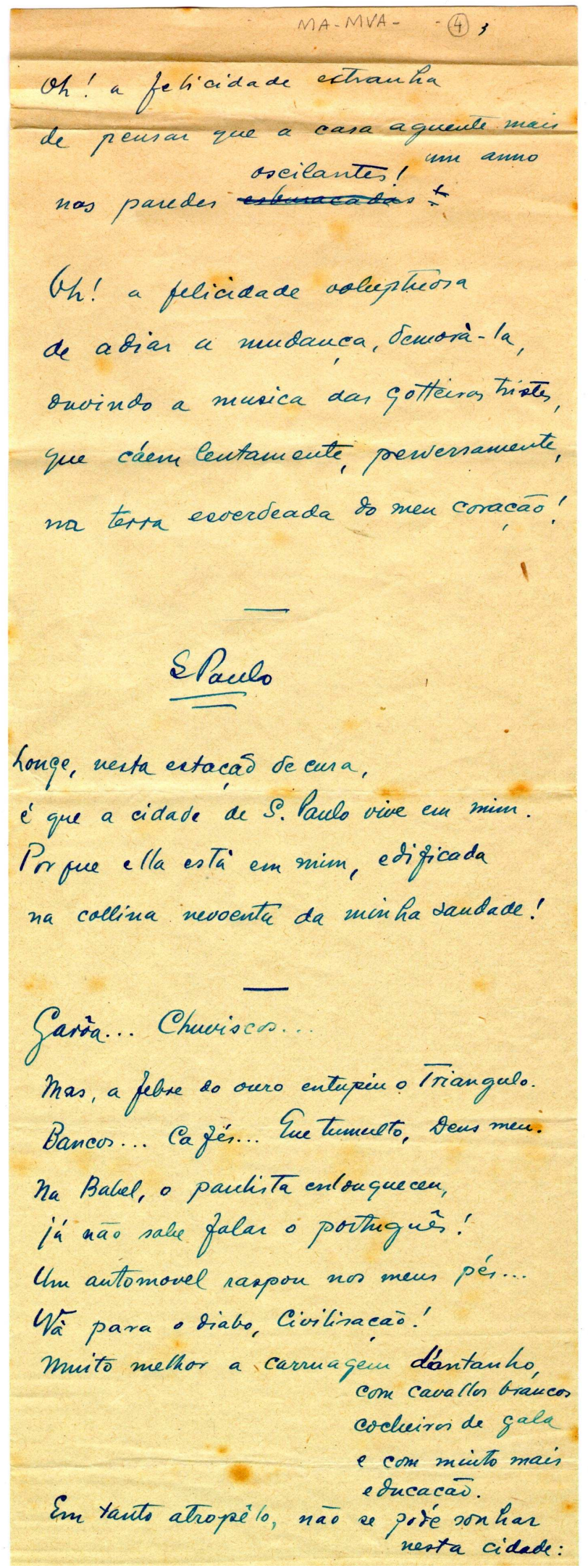




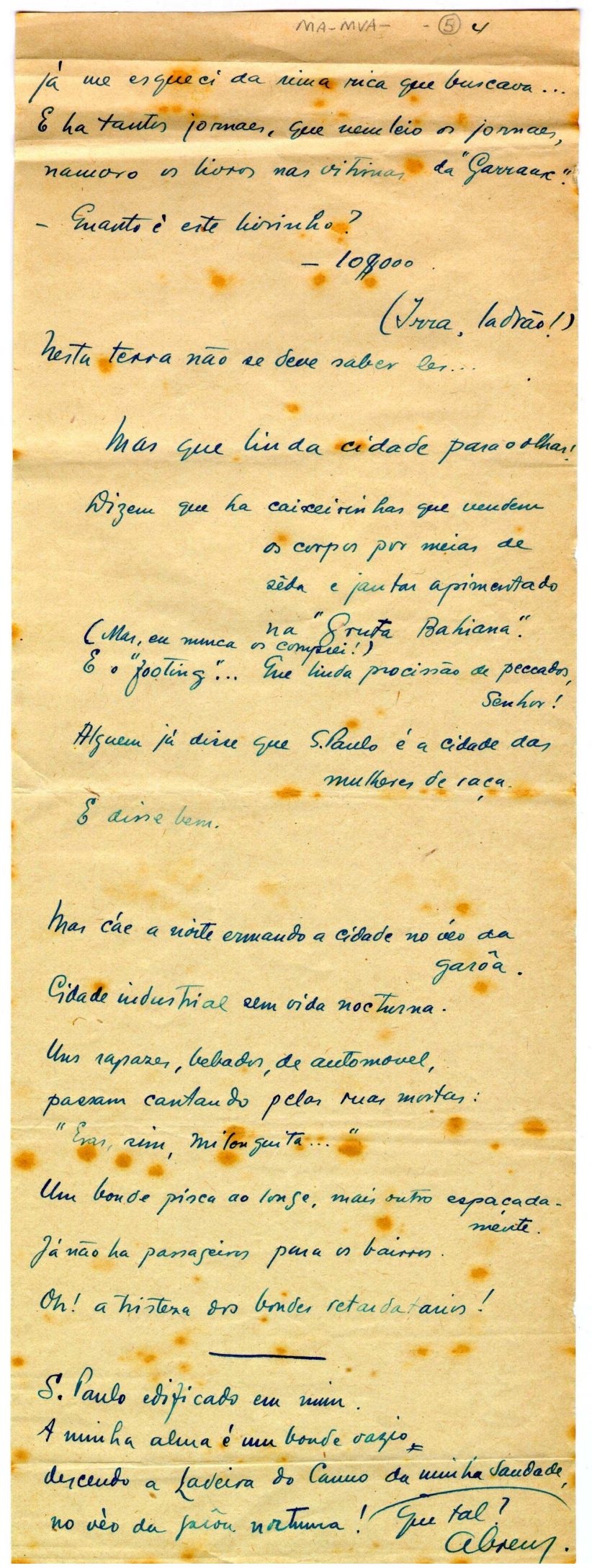




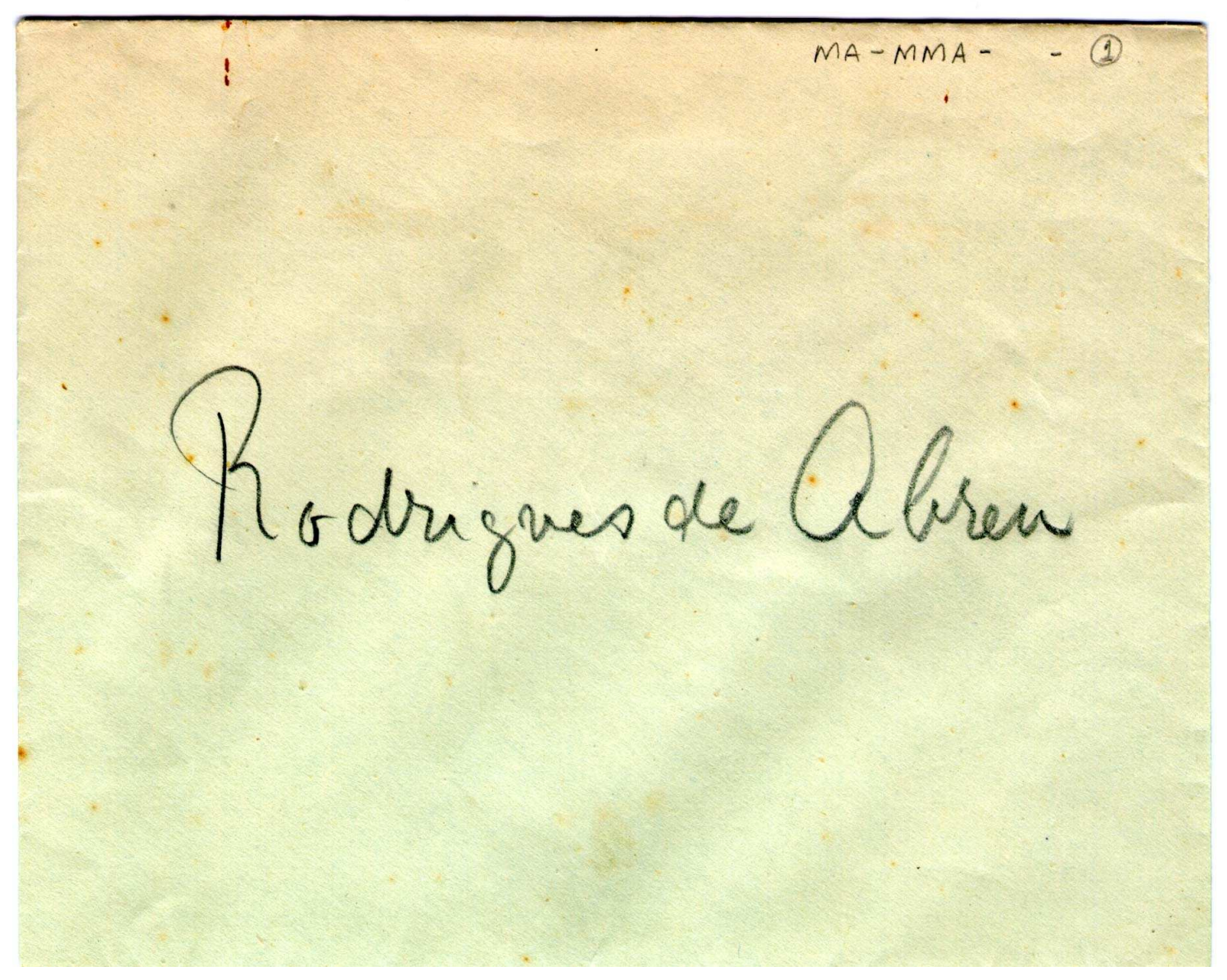

32 
4. O poema Nos campos da Flandres é tradução de In Flanders Fields, escrito em 1915 pelo físico e poeta canadense John Mac Grae (1872-1918). Durante a I Guerra Mundial, Mac Grae serviu na corporação médica e externou no poema suas impressões da batalha de Ypres. O livro In Flanders Fields and other poems foi publicado em 1919.

5. Na biblioteca MA encontra-se um exemplar da $1^{\mathrm{a}}$ edição de Olho d'água (São Paulo, Livraria Saraiva, 1937), obra na qual não figuram os textos nos ms supra citados. Traz a dedicatória: "A | Mario de Andrade, | espirito de homem de | letras cujas qualida- | des

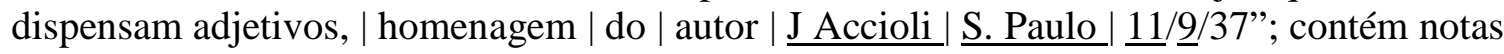
da leitura de MA, a lápis vermelho.

\section{Estudo genético:}

1. No arquivo MA o poema Morte apresenta-se em duas versões, A e B, no datiloscrito cópia carbono (f. 25, 28), com variantes. Ambas mostram 1 etapa na escritura.

2. Os demais poemas apresentam-se em uma única versão, A.

3. Pórtico Os meus ipês, Mulher, Agonia, Serenata, Sombra, Profissão de fé, Encantamento, Uma demagogiazinha, Si ei morresse amanhã..., Penumbra de bar, Repartição, Cega, Arvore, A canção de amanhã mostram 2 etapas na escritura: a-a ${ }_{1}$ : a: datiloscrito completo; $\mathrm{a}_{1}$ : rasuras a tinta preta.

4. A versão no datiloscrito foi confrontado com a versão impressa, $\mathrm{C}$ em $A$ canção do amanhã (ed. cit.).

5. Há variantes entre as versões A e C; entre elas, a substituição de títulos: A: Pórtico - C: "Mensagem"; A: Agonia - C: "Agonia da noite"; A: Encantamento - C: "Poema brandamente humano"; A: Uma demagogiazinha - C: "Poema de um lirismo vago".

6. Mar foi incluído na $4^{\mathrm{a}}$ ed. de Olho d'água (São Paulo, Obelisco, 1967); apresenta variantes em relação à versão $\mathrm{A}$.

\section{MA - MOE, 03-08}

ACCIOLY, Breno Rocha (1921-1966)

03. A cantiga do cego; conto (MAm)

[Maceió, ant. fev. 1942?]

Datiloscrito, cópia carbono roxo; papel branco; 4 folhas, 32,5 x 22,3/22,4 cm; f. 2 : rasgamento na borda esquerda inferior; vinco; sinais de fungo; folhas numeradas pelo escritor 2-4; escrita no anverso; f. 1: assinatura a máquina: "(Breno Accioly)"; f. 1-2: rasuras a máquina; grifos do escritor a lápis preto; fólios numerados pela pesquisa: (1)(4).

\section{A noite trazia muita dor; conto (MAm)}

[Maceió, ant. fev. 1942?]

Datiloscrito, cópia carbono roxo; papel branco; 3 folhas; f. 1: 32,6/32,8 x 22,1/22,2 cm, f. 2: 32,7 x 22,1/ $22,2 \mathrm{~cm}$, f. $3: 32,4$ x 22,2; vinco; sinais de fungo; folhas numeradas pelo escritor 2-3; escrita no anverso; f. 1: assinatura a máquina: “- Breno Accioly -"; rasuras a máquina e a lápis preto; fólios numerados pela pesquisa: (1)-(3). 
05. A volta de Abigail; conto (MAm)

[Maceió, ant. fev. 1942?]

Datiloscrito, cópia carbono roxo; papel branco; 4 folhas; 32,5/32,6 x 21,9 cm; vinco; sinais de fungo; escrita no anverso; folhas numeradas pelo escritor 2-4; f. 1: assinatura a máquina: "Breno Accioly"; rasuras a máquina; fólios numerados pela pesquisa: (1)-(4).

Nota MA a lápis vermelho: "Pernambuco".

06. Claridade; conto (MAm)

[Maceió, ant. fev. 1942?]

Datiloscrito, cópia carbono roxo; papel branco; 3 folhas; 32,7 x 22,1/22,2 cm; vinco; sinais de fungo; folhas numeradas pelo escritor 2-3; escrita no anverso; sem assinatura; f. 2-3: rasuras a máquina; fólios numerados pela pesquisa: (1)-(3).

Nota MA a lápis vermelho: "Breno Acióli".

07. Para Menescal a vida é de papo pro ar; conto (MAm)

[Maceió, ant. fev. 1942?]

Datiloscrito, cópia carbono roxo; papel branco; 4 folhas; 32,7 x 22,1/22,2 cm; vinco; sinais de fungo; f. 4: marcas de ferrugem; sinais de amassado; folhas numeradas pelo escritor 2-4; escrita no anverso; sem assinatura; f. 1,3: rasuras a máquina; fólios numerados pela pesquisa: (1)-(4).

Nota MA a lápis vermelho: "Breno Acióli".

08. Vespera de formatura; conto (MAm)

[Maceió, ant. fev. 1942?]

Datiloscrito, cópia carbono roxo; papel branco; 6 folhas; f. 1-4: 32,7 x 22,1/22,2cm, f. 5-6: 32,5 x 23,3 cm; vinco; sinais de fungo; folhas numeradas pelo escritor 2-6; escrita no anverso; sem assinatura; rasuras a máquina; fólios numerados pela pesquisa: (1)-(6).

Nota MA a lápis vermelho: "Breno Acióli".

Notas da pesquisa:

1. Ms na vertente Mário de Andrade mentor.

2. Data e local atestados com base na carta de BA a MA, datada: "Maceio - 2 - 2 - 942", na qual o remetente comenta o envio de contos, possivelmente estes presentes no Arquivo MA. Trata-se de uma única menção ao envio de contos que não oferece, contudo, os títulos.

3. Os textos recebidos por MA são inéditos, ao que se pode calcular, pois não constam dos livros de contos de BA: João Urso (Rio de Janeiro, EPASA, 1944); Cogumelos (Rio de Janeiro, Editora A Noite, 1949); Maria Pudim (José Olympio, 1955); Os cata-ventos (Rio de Janeiro, Livraria José Olympio Editora, 1962).

4. Na quarta capa de João Urso (ed. cit.), 1944, está impresso, entre declarações de outros escritores, o comentário de MA: "Breno Accioly de um nada faz um conto e acende numa vela a chama da angústia humana. Breno Accioly é indiscutivelmente, um dos maiores talentos da nossa geração". O comentário de MA surgiu após a leitura deste ms. Incluído em carta (não localizada), foi de lá retirado, ao que se pode considerar, com base na explicação agregada pelo autor à dedicatória do volume, à revelia do remetente, para figurar no livro. 
5. No exemplar da biblioteca MA, no verso da página de ante-rosto, ao lado da dedicatória na página de rosto - "Para Mario de Andrade, | com o abraço muito | amigo do | Breno | Rio-30-11-44" -, se lê: "Mario: a referência da | contra-capa assinada por | você, foi de uma carta de | 1943. Aliás, eu o preveni, mas | a carta se extraviou. Creio que | você não irá ficar chateado. | Vou lhe mandar um exemplar | de luxo que está bem feito. |É presente. | Até em breve | Breno. | Me escreva dizendo alguma | coisa sobre João Urso. $\mathrm{O} \mid$ que achou, etc..."

\section{Estudo genético:}

1. No arquivo MA os textos apresentam-se em única versão, A, que exibem, nos contos $A$ volta de Abigail, Claridade, Para Menescal a vida é de papo pro ar e Vespera de formatura, 2 etapas na escritura: $\mathrm{a}_{1}-\mathrm{a}_{2}$, e nos contos $A$ cantiga do cego e A noite trazia muita dor, 3 etapas na escritura: $\mathrm{a}_{1}-\mathrm{a}_{2}-\mathrm{a}_{3}$ :

$\mathrm{a}_{1}$ : datiloscrito completo;

$\mathrm{a}_{2}$ : rasuras a máquina;

$\mathrm{a}_{3}$ : rasuras a lápis preto.

\section{MA - MOE, 09}

\section{ACCIOLY, Breno Rocha (1921-1966)}

09. As dunas; romance (MAm)

[Recife], 1942-[ant. maio 1943]

Datiloscrito, cópia carbono azul; papel branco; 133 folhas; f. 1-7: 32,5 x 22,0 cm, f. 844: 32,8 x 21,9 cm, f.45-133: 32,8 x 22,0/22,1, com variação em mm na altura ou na largura; pequenos rasgamentos nas bordas; sinais de amassado; margem esquerda: furos para arquivamento; sinais de fungo; manchas de carbono; f. 1: rasgamentos nas bordas e na margem esquerda, sinais de amassado, ferrugem de ferro de pasta para arquivamento na margem esquerda; f. 8-34: letras borradas; f. 84: 1 furo no centro do papel; folhas numeradas pelo escritor 2-133; escrita no anverso; capa, f. 1: título e data em autógrafo a máquina: "As Dunas - Romance | Breno Accioly" | 1942"; rasuras em autógrafo a tinta preta; fólios numerados pela pesquisa: (1)-(1) (3) (3).

Notas MA a lápis preto: f. 1: substituição no título: "As - Dunas"; endereço de BA: "r. Xavier da Silveira, 34 | Copacabana | rua Aarão Reis, 111 | Sta. Tereza - Vista Alegre | Rio"; sugestões de substituição, grifos em pronomes possessivos e pessoais, sinais de interrogação, traços verticais verticais e cruzetas na margem destacando trechos, ao longo do ms.

\section{Anexo:}

Carta de MA a BA; datada: "São Paulo, 27-VII-43"; sem assinatura; forma de tratamento: "Meu caro Breno Acioli,"; datiloscrito, cópia carbono azul; papel branco; 1 folha; 32,2 x $22 \mathrm{~cm}$; sinais de fungo, escrita no anverso e no verso; fólio numerado pela pesquisa: (1) (3) (4). Conteúdo: análise de Dunas .

(Ref. Cruzada: sub-série Correspondência Ativa; série Correspondência Mário de Andrade -, MA-C-CAMVA, $\left.n^{\circ} 4\right)$. 
Notas da pesquisa:

1. Ms na vertente Mário de Andrade mentor.

2. O ms foi encaminhado a MA em 12 de maio de 1943, pelo que se deduz da carta de BA do Rio de Janeiro, 14 de maio desse ano, onde se lê: "Como ficou combinado enviei ante- $\mid$ ontem os originaes da DUNAS - romance | que escrevi no ano passado e que, agora, | humildemente peço sua opinião que de | ha muito desejava saber". Ref.: subsérie Correspondência Ativa; série Correspondência Mário de Andrade -, MA-C-CPL, $\left.\mathrm{n}^{\circ} 50\right)$.

O fato de conter rasuras a lápis e a tinta, dilata o tempo da escritura, justificando a datação que combina o ano explícito no ms, 1942, aos dados de dia, mês e ano presentes na carta de 1943 citada.

3. O ms recebeu Notas MA que deram base à carta a BA, escrita em São Paulo, 27 de julho de 1943, cuja cópia foi agregada pelo crítico ao ms, ao que se pode inferir, com o escopo de nela escudar a leitura de possíveis reformulações do texto em outra versão. MA analisa o romance e aconselha o autor, por exemplo, a banir o excesso de possessivos, próprios, segundo ele, da língua francesa.

4. BA, conforme indicam suas cartas a MA no início do ano de 1943, transferira-se recentemente para o Rio de Janeiro. Os endereços anotados por MA na folha 1 referemse a mudança de residência na então Capital Federal, na metade do ano, pois, em 2 de junho de 1943 BA lhe informa: "Agora mesmo estou de mudança para $\mid \mathrm{St}^{\mathrm{a}}$ Tereza, Aarão Reis - 111 - e como não | desejo, nem quero que a sua proxima |carta falando sobre 'DUNAS' se extravie, resol- | vi mais uma vez lhe importunar. | Estou curioso por saber a sua opinião | acerca de meu romance e gostaria mui- | tissimo que você me enviasse uma carta $\mid$ especie de artigo, pois a mesma poderia pu- | blicar quando estreiasse". (Ref.: série Correspondência Mário de Andrade - sub-série Correspondência passiva, MA-C-CPL, $\mathrm{n}^{\circ} 51$ )

5. Em 22 de agosto de 1943, BA agradece a crítica externada pela carta (Ref.: série Correspondência Mário de Andrade - sub-série Correspondência passiva, MA-C-CPL, $n^{\circ}$ 52) e dá início ao processo de reelaboração do romance, relatado na continuação de seu diálogo epistolar com MA. A primeira menção à reescrita vem na carta de BA a MA, do Rio de Janeiro, 27 de setembro de 1943. Depois dela, outras trazem notícias do romance. Na última, a de 29 de setembro de 1944, o romancista, ante à possibilidade de fechar contrato com a editora José Olympio, anuncia uma nova versão: "Na semana passada assinei o contrato do lançamento de "Dunas" pelo José Olimpio. É pena que não disponha de | uma copia. Gostaria que voce reparasse como o romance | ficou melhor, bem diferente daquele primeiro despenteado, | quase acefalo." (Ref.: série Correspondência Mário de Andrade - sub-série Correspondência passiva, MA-C-CPL, $\mathrm{n}^{\circ} 53$ e MA-C-CPL, $\mathrm{n}^{\circ} 63$, respectivamente)

6. Dunas tem a primeira edição em 1955.

\section{Estudo genético:}

1. No arquivo MA o texto apresenta-se em uma única versão, A, o datiloscrito em cópia carbono que mostra 3 etapas na escritura: $a-a_{1}-a_{2}$.

a: datiloscrito completo;

$\mathrm{a}_{1}$ : rasuras a máquina;

$a_{2}$ : rasuras a tinta preta e a lápis. 
2. As Notas MA atestam a leitura do ms e vinculam-se, como notas prévias, à carta a BA de 27 de julho de 1943.

\section{MA - MOE, 10}

ALMEIDA, Fernando Mendes (Fernando Henriques Mendes de Almeida, 1909-1968)

10. Poemetos da sombra; poesia (MAm)

[São Paulo], 1929

Autógrafo a tinta preta; papel branco, timbrado: "MUNICIPALIDADE DE SÃO PAULO| PROCURADORIA FISCAL", margens verticais impressas em vermelho, filigrana: "SELECTED BOND EXTRA STRONG"; 2 folhas; 32,5 x 22,0 cm; vinco; sinais de fungo; furo de grampeador na margem esquerda; escrita no verso; f. 1: data abaixo do título: "(1929)"; fólios numerados pela pesquisa: (1)-(2).

Notas MA a lápis preto na f. 1: sugestão de substituição e opinião sobre o poema: "otimo, magistral".

Notas da pesquisa:

1. Ms na vertente Mário de Andrade mentor.

2. Ms apresentados a MA em 1939, quando FEMA trabalhava no Departamento de Cultura da Municipalidade de São Paulo.

Estudo genético:

1. A classificação contempla os ms no arquivo MA.

2. No arquivo MA Poemetos da sombra apresenta-se em 2 versões. A versão no autógrafo acima classificado, foi considerada A pela pesquisa. A versão anterior, B, leva o título "Sois Pandóra e Ford a um só tempo!" (V. análise documentária de "Sois Pandóra e Ford a um só tempo!": MA - MOE, 12).

3. Poemetos da sombra, na versão B, mostra 1 etapa na escritura.

\section{MA - MOE, 11}

ALMEIDA, Fernando Mendes de (Fernando Henriques Mendes de Almeida 1909-1968)

11. "Quid homo sequeris ineptam laetitam?”; ensaio filosofia (MAm)

[São Paulo], 1930

Datiloscrito: f. 1-2: cópia carbono azul, f. 2-4: cópia carbono roxo; papel branco; 4 folhas; f. 1: $32,4 / 32,6 \mathrm{~cm}$ x 21,3/21,4 cm, f. 2: $32,5 \mathrm{~cm}$ x 21,3/21,4 cm, f. 3-4: 32,4/32,6 $\mathrm{cm} \times$ 21,3/ 21,5 cm; vincos; sinais de fungo, f. 2-4: escrita borrada; rasuras: f. 1-4: a tinta preta, f. 2-4: a máquina; folhas numeradas pelo escritor: 1 a 4; fólios numerados pela pesquisa: (1)-(4).

Nota MA a lápis preto: “1930”. 
Notas da pesquisa:

1. Ms na vertente Mário de Andrade mentor.

2. Neste estudo, escrito em 1930, por ocasião do lançamento do livro de poemas de MA Remate de Males, FeMA faz uma retrospectiva crítica da obra do escritor.

3. A pesquisa datou o ms pela Nota MA: "1930", e pelo fato de Remate de Males ter sido publicado nesse ano.

Estudo genético:

1. No arquivo MA o texto apresenta-se em uma única versão, A, o datiloscrito em cópia carbono que mostra 3 etapas na escritura: $a-a_{1}-a_{2}$ :

a: datiloscrito completo;

$\mathrm{a}_{1}$ : rasuras a máquina;

$\mathrm{a}_{2}$ : rasuras a tinta preta.

\section{MA - MOE, 12}

ALMEIDA, Fernando Mendes de (Fernando Henriques Mendes de Almeida 1909-1968)

12. Alguns poemas da constância da sombra, poesia (MAm)

São Paulo, 1932

Datiloscrito original, fita preta e vermelha; papel branco; 24 folhas; $22 \times 16,3 / 16,5 \mathrm{~cm}$, com variação em mm; sinais de fungo; manchas de acidez; escrita no anverso; assinaturas de FeMA a lápis preto; folhas numeradas pelo escritor; rasuras a tinta preta e a lápis preto; fólios numerados pela pesquisa: (1)-(2) (6). Notas MA. Capa improvisada em papel branco dobrado ao meio; com dedicatória, título, data e local no anverso: "Para Mário | Alguns poemas da constancia da sombra | 1932 | São Paulo | São Paulo"; no verso, texto incompleto de FeMA, em autógrafo a tinta preta: "Num jardim cataram uma rosa no pé do | sol e o ventinho de mato que vinha do girasol deix".

O conjunto de ms apresenta os títulos:

Infinito:

Datiloscrito original, fita preta e vermelha; 1 folha; assinatura: "Fernando | Mendes de | Almeida."; folha numerada pelo escritor: 1.

Nota MA a lápis tinta: traço e pequeno círculo à margem esquerda da $1^{\mathrm{a}}$ estrofe, destacando-a.

Perfil do poeta mago:

datiloscrito original, fita preta e vermelha; 2 folhas; f. 2: tinta borrada; f. 2: assinatura: "Fernando Mendes de | Almeida"; folhas numeradas pelo escritor: 2-3.

Nota MA: f. 1: a lápis tinta: pequeno círculo à esquerda do título na margem superior. 


\section{Toada diaria:}

Datiloscrito original, fita preta e vermelha; 1 folha; folha numerada pelo escritor: 4; assinatura: "Fernando Mendes de Almeida.".

Nota MA a lápis tinta: pequeno círculo à esquerda do título na margem superior.

Ode I:

Datiloscrito original, fita preta e vermelha; 2 folhas; folhas numeradas pelo escritor: 5-6; assinaturas: f. 1: "F", f. 2: "Fernando | Mendes | de | Almeida.". Nota MA: f. 2: a lápis tinta: f. 1: pequeno círculo à esquerda do título na margem superior; traço com interrogação à margem esquerda dos 3 últimos versos.

Ode II:

Datiloscrito original, fita preta e vermelha; 1 folha; assinatura: "Fernando Mandes de Almeida."; folha numerada pelo escritor: 7.

"Sois Pandóra e Ford a um só tempo!":

Datiloscrito original, fita preta e vermelha; 1 folha; assinatura: "Fernando Mendes |de Almeida"; folha numerada pelo escritor: 1.

Nota MA a lápis tinta: pequeno círculo na margem superior.

"Vinde ao meu reduto hospitaleiro.":

Datiloscrito original, fita preta e vermelha; 1 folha; assinatura: "Fernando | Mendes | de | Almeida."; folha numerada pelo escritor: 2.

Nota MA a lápis tinta: pequeno círculo à esquerda do título na margem superior.

"Passai por mim sem um resmungo":

Datiloscrito original, fita preta e vermelha; 1 folha; assinatura: "Fernando Mendes de Almeida"; folha numerada pelo escritor: 1.

"Não! Agora podeis partir. Deixar tudo.":

Datiloscrito original, fita preta e vermelha; 1 folha; assinatura: "Fernando | Mendes de | Almeida"; folha numerada pelo escritor: 3.

Nota MA a lápis tinta: pequeno círculo à esquerda do título na margem superior.

Chôro calado:

Datiloscrito original, fita preta e vermelha; 3 folhas; f. 3: assinatura a lápis preto: "Fernando Mendes de | Almeida"; folhas numeradas pelo escritor: 2-3. 
"Comei Golias! Atenas vos dará medalhas.":

Datiloscrito original, fita preta e vermelha; 1 folha; assinatura: "Fernando Mendes | de Almeida"; folha numerada pelo escritor: 4.

Notas MA a lápis tinta: pequeno círculo à esquerda do título na margem superior; entre a $1^{\mathrm{a}}$ e a $2^{\mathrm{a}}$ estrofe: marcação para nota de rodapé: “(1) —”; margem inferior: "(1) Mania dos contrastes, | quasi V. Hugo.”.

"Delirios que vos defendem atentados...":

Datiloscrito original, fita preta e vermelha; 1 folha; assinatura: "Fernando Mendes de | Almeida."; folha numerada pelo escritor: 5.

Nota MA a lápis tinta no $4^{\circ}$ verso: parêntesis destacando "do".

"Certo vencereis amanhã o proprio corpo!":

Datiloscrito original, fita preta e vermelha; 1 folha; assinatura: "Fernando Mendes de | Almeida."; folha numerada pelo escritor: 6.

Nota MA a lápis tinta: pequeno círculo na margem superior.

"Dôce amor que me acontece":

Datiloscrito original, fita preta e vermelha; 1 folha; assinatura: "Fernando | Mendes de | Almeida."; poema numerado pelo escritor: 1.

"Junte esse amor do chão do tedio":

Datiloscrito original, fita preta e vermelha; 1 folha; assinatura: "Fernando | Mendes de | Almeida."; poema numerado pelo escritor: 2.

"Cavaleiro do exilio que me tólhe...":

Datiloscrito original, fita preta e vermelha; 1 folha; assinatura: "Fernando | Mendes de | Almeida."; folha numerada pelo escritor: 2.

Notas MA a lápis tinta: pequeno círculo à esquerda do título na margem superior; último verso: parêntesis destacando a palavra "vós" e traço suprimindo a letra "s" da mesma palavra.

Elegio das locomoções:

Datiloscrito original, fita preta; título: autógrafo a lápis preto; 1 folha.

Nota MA a lápis tinta: pequeno círculo à esquerda do título na margem superior.

"Esta tristeza que é sua, é minha.":

Datiloscrito original, fita preta; 1 folha; assinatura: "Fernando Mendes de | Almeida".

Nota MA a lápis tinta: pequeno círculo à esquerda do título na margem superior. 
"Minhas vigilias começáram ontem!":

Datiloscrito original, fita preta; 1 folha; assinatura: "Fernando Mendes de Almeida.".

Notas MA a lápis tinta: $7^{\circ}$ verso: grifo em "uma vída sem vida"; margem esquerda: "V. Hugo"; em relação ao último verso: "Prefiro: | 'Inutil, | Como a poesia universal"".

Lar angular:

Datiloscrito original, fita preta; título: autógrafo a lápis preto; 1 folha; assinatura: "Fernando | Mendes de | Almeida".

Nota MA a lápis tinta: pequeno círculo à esquerda do título na margem superior.

"Ai, posso querer mel, dôce de abobra":

Datiloscrito original, fita preta; 1 folha; assinatura: "Fernando | Mendes | de Almeida.".

Notas da pesquisa:

1. Ms na vertente Mário de Andrade mentor.

2. Com exceção de Elegia das locomoções, publicado em Carrussel fantasma (São Paulo, Editora SPES, 1937), os poemas recebidos por MA são inéditos em livro.

3. Há dois exemplares de Carrussel fantasma na biblioteca MA. O primeiro guarda na folha de rosto a dedicatória: "Ao | Mario, | camarada- | mente, of. | o | Fernando S.P. 14.V.37”, e, à p. 5, a dedicatória impressa: "A | Mario de Andrade.”; o segundo exemplar traz, ao longo das páginas, no verso da capa e na folha de ante-rosto anotações da leitura feita por MA.

4. As anotações marginais de MA no exemplar de Carrussel fantasma são notas prévias para o artigo "As três faces do eu", que saiu na sua coluna "Vida literária", no Diário de Notícias do Rio de Janeiro, em 28 de maio de 1939. MA focalizou Carrussel fantasma, de FeMA, ao lado de outros dois livros recém-lançados: A Menina Boba, de Oneida Alvarenga, e Porto inseguro, de Rossini Camargo Guarnieri. (Documento no Arquivo Fernando Mendes de Almeida, série Matéria extraída de periódicos, álbum 2, f.10, IEBUSP)

5. Em carta a MA, em 2 de junho 1939, FeMA comenta o artigo do amigo: "Ótima a sua| compreensão do | "Carrussel". | Cá, entendemos, | a unica que | correspondeu | à espectativa | Fernando". (Ref.: série Correspondência Mário de Andrade - sub-série Correspondência passiva; MA-C-CPL, ${ }^{\circ} 153$ )

Estudo genético:

1. As versões dos textos estão classificadas conforme aparecem no arquivo MA.

2. O poema "Sois Pandóra e Ford a um só tempo!", foi considerado versão B pois apresenta uma versão anterior intitulada Poemetos da sombra (V. análise documentária de Poemetos da sombra: MA-MOE, 10).

3. Os demais poemas apresentam-se em uma única versão, A.

4. Infinito e "Sois Pandóra e Ford a um só tempo!" mostram 1 etapa na escritura. 
5. "Dôce amor que me acontece" e "Junte esse amor do chão do tedio" mostram 2 etapas na escritura: $a-a_{1}$ :

a: datiloscrito completo;

$\mathrm{a}_{1}$ : rasuras a máquina.

6. Toada diaria, Ode II e "Certo vencereis amanhã o próprio corpo!" mostram 2 etapas na escritura: $a-a_{1}$ :

a: datiloscrito completo;

$\mathrm{a}_{1}$ : rasuras a lápis preto.

7. Perfil do poeta mago apresenta-se em uma única versão, A, que mostra 2 etapas na escritura: $\mathrm{a}_{-} \mathrm{a}_{1}$ :

a: datiloscrito completo;

$\mathrm{a}_{1}$ : rasuras a tinta preta.

8. "Passai por mim sem um resmungo", "Comei Golias! Antenas vos dará medalhas", "Delirios que vos defendem atentados...", "Cavaleiro do exilio que me tólhe...", Elegia das locomoções, "Esta tristeza que é sua, é minha", "Minha vigilias começáram ontem!" e "Ai, posso querer mel, dôce de abobra" mostram 3 etapas na escritura: a-a ${ }_{1}$ $\mathrm{a}_{2}$ :

a: datiloscrito completo;

$\mathrm{a}_{1}$ : rasuras a máquina;

$a_{2}$ : rasuras a lápis preto

9. Ode I, "Vinde ao meu reduto hospitaleiro", "Não! Agora podeis partir. Deixar tudo.", Chôro calado, Lar angular mostram 4 etapas na escritura: $\mathrm{a}_{1}-\mathrm{a}_{2}-\mathrm{a}_{3}$ :

a: datiloscrito completo;

$\mathrm{a}_{1}$ : rasuras a máquina;

$\mathrm{a}_{2}$ : rasuras a tinta preta;

$\mathrm{a}_{3}$ : rasuras a lápis preto.

10. A versão A de Elegia das locomoções foi confrontada com a versão impressa, B: ALMEIDA, Fernando Mendes de. Carrussel fantasma. São Paulo, Editora SPES, 1937. Há variantes.

\section{MA - MOE, 13}

ALMEIDA, Fernando Mendes (Fernando Henriques Mendes de Almeida, 1909-1968)

13. Exegése do "Carrussel fantasma"; depoimento (MAm)

[São Paulo, post. 1937]

Datiloscrito, cópia carbono azul; papel branco; 7 folhas; f. 1-5, 7: 30,1/30,2 x 22,1/22,2 cm, f. 6: 30,1 x 22,1/22,2 cm; vincos; sinais de fungo; 2 furos de grampeador; f. 1-7: rasgamento na borda superior à esquerda; f. 1-6: rasuras a máquina, f. 4: rasuras a tinta preta; folhas numeradas pelo escritor: 1-7; fólios numerados pela pesquisa: (1)-(7).

Notas da pesquisa:

1. Ms na vertente Mário de Andrade mentor.

2. O ms é depoimento sobre a criação de Carrussel fantasma.

3. A data do ms foi atestada tomando como referência o ano da publicação de Carrussel fantasma, 1937 (São Paulo, SPES). 
Estudo genético:

1. No arquivo MA o texto apresenta-se em uma única versão, A, o datiloscrito em cópia carbono que mostra 3 etapas na escritura: $a-a_{1}-a_{2}$ :

$\mathrm{a}_{1}$ : datiloscrito completo;

$\mathrm{a}_{2}$ : rasuras a máquina;

$\mathrm{a}_{3}$ : rasuras a tinta preta.

\section{MA - MOE, 14}

ALMEIDA, Fernando Mendes (Fernando Henriques Mendes de Almeida, 1909-1968)

14. "Ó o eterno desalento dos incompreendidos!..."; poesia (MAm)

São Paulo, 17 jul. 1939

Poema enviado por FeMA a MA no corpo da carta datada: "SP. 17/VII/39"; assinada:

"Fernando"; forma de tratamento: "Mario,"; datiloscrito original, fita preta; papel branco, filigrana; 1 folha; 33 x 21,9 cm; vincos; sinais de fungo; mancha; escrita no anverso; rasuras a máquina e a tinta preta; fólio numerado pela pesquisa: (1).

(Ref. Cruzada: série Correspondência Mário de Andrade - sub-série Correspondência passiva; MA-C-CP 156)

Notas da pesquisa:

1. O ms na vertente Mário de Andrade mentor.

2. Na carta citada FeMA indica: "Para destoar do menú esta carta vai seguida de um poêma:"

\section{Estudo genético:}

1. No arquivo MA o poema apresenta-se em uma única versão, A, passado a impo no datiloscrito original que mostra 3 etapas na escritura: $a-a_{1}-a_{2}$ :

$\mathrm{a}_{1}$ : datiloscrito completo;

$\mathrm{a}_{2}$ : rasuras a máquina;

$\mathrm{a}_{3}$ : rasura a tinta preta.

\section{MA - MOE, 15}

ALMEIDA, Fernando Mendes (Fernando Henriques Mendes de Almeida, 1909-1968)

15. "Quando a vossa mão me acena"; "A alegria no ar me atordôa nesta tarde branda."; Ponteio da recomposição; poesia (MAm)

São Paulo, 16 ago. 1939

Poemas enviados por FeMA a MA no corpo da carta datada: "SP. 16/ VIII/ 39"; assinatura a máquina: ".- O Fernão" e a tinta preta: "Fernão"; forma de tratamento: "Mario,"; datiloscrito, cópia carbono azul; papel branco timbrado da Municipalidade de São Paulo; 3 folhas; f. 1: 32,5/32,6 x 22,5 cm, f. 2: $32,4 / 32,5$ x 22,0/22,1 cm; f. 1: rasgamento na borda esquerda; f. 2: rasgamentos nas bordas superior e esquerda e sinais de amassado no canto inferior esquerdo; f. 3: rasgamentos na borda direita e sinais de 
amassado no canto inferior esquerdo; vincos; sinais de fungo; folha numerada pelo escritor: 3; f. 1: escrita no anverso e no verso, f. 2-3: escrita no anverso; rasuras a máquina e a tinta preta; fólios numerados pela pesquisa: (1)-(3). Notas MA.

(Ref. cruzada: série Correspondência Mário de Andrade - sub-série Correspondência passiva; MA-C-CPMVA 158).

"A alegria no ar me atordôa nesta tarde branda.":

Notas MA a lápis vermelho: grifos em palavras.

Ponteio da recomposição:

Notas MA a lápis preto na f. 2: correção a erros de datilografia.

Notas da pesquisa:

1. Ms na vertente do Mário de Andrade mentor.

2. A carta de FeMA a MA [São Paulo, post. 6 set. 1939] responde aos comentários de MA sobre os poemas no ms. (Ref. série Correspondência Mário de Andrade - sub-série Correspondência passiva; MA-C-CPL, $\mathrm{n}^{\circ} 160$ )

\section{Estudo genético:}

1. No arquivo MA os textos apresentam-se em uma única versão, A, o datiloscrito em cópia carbono que mostra 3 etapas na escritura:O ms apresenta-se em uma única versão,

A, que mostra 3 etapas na escritura $a-a_{1}-a_{2}$ :

a: datiloscrita completo;

$\mathrm{a}_{1 \text { : }}$ rasuras a máquina;

$\mathrm{a}_{2:}$ rasuras a tinta preta.

\section{MA - MOE, 16}

ALMEIDA, Fernando Mendes (Fernando Henriques Mendes de Almeida, 1909-1968)

16. O Natal de Saturnino; conto (MAm)

[São Paulo, ant. 06 set. 1939]

Datiloscrito, cópia carbono azul; papel branco, filigrana; 3 folhas, f. 1: 33,2 x $22 \mathrm{~cm}$, f. 2: 33,2 × 22/22,3 cm, f. $3: 33,2$ × 21,9/22,3 cm; f. 1-3: borda direita irregular, f. 2 : borda esquerda irregular; vincos; sinais de fungo; escrita no anverso; rasuras a máquina e a tinta preta; f. 3: assinatura a máquina: "Fernando Mendes de Almeida"; folha numerada pelo escritor: 3; fólios numerados pela pesquisa: (1)-(3). Nota FeMA a tinta preta, f. 1: "Para | "O Cruzeiro")". Bilhete de FeMA a Guilherme Figueiredo na margem inferior da f. 3: assinaturas a máquina: "Fernão", a tinta preta: "Fernão"; forma de tratamento: "guilherme velho,"; datiloscrito, cópia carbono azul; papel branco, filigrana; 1 folha; fólio numerado pela pesquisa: (3). 
Notas da pesquisa:

1. Ms na vertente Mário de Andrade mentor.

2. O conto foi escrito a convite de Guilherme Figueiredo, para ser publicado na revista carioca $O$ Cruzeiro, conforme se depreende do bilhete vinculado à folha 3: "Vai aí o conto, feito ao correr... da maquina. muito grato pela sua lembrança".

3. Guilherme Figueiredo pedira também a MA, em carta do Rio de Janeiro, 3 de agosto de 1939, um conto de Natal para a mesma revista (Ref.: série Correspondência Mário de Andrade - sub-série Correspondência passiva; MA-C-CPL, n³031). MA publica n' $O$ Cruzeiro "Briga de pastoras".

4. FeMA na carta de [São Paulo, post. 6 set. 1939], dirigida a MA, coloca em suas dificuldades financeiras a razão de ter aceitado o convite de última hora para escrever $O$ Natal de Saturnino. (Ref.: série Correspondência Mário de Andrade - sub-série Correspondência passiva; MA-C-CPL, $\mathrm{n}^{\circ}$ 160)

\section{Estudo genético:}

1. No arquivo MA o texto apresenta-se em uma única versão, A, o datiloscrito em cópia carbono que mostra 2 etapas na escritura: $a-a_{1}$ :

a: datiloscrito completo;

$\mathrm{a}_{1}$ : rasuras a máquina.

\section{MA - MOE, 17}

ALMEIDA, Fernando Mendes (Fernando Henriques Mendes de Almeida, 1909-1968)

17. "Quiséra amar-te, mas não tenho tempo"; poesia (MAm)

[São Paulo], 1935- 1939

Autógrafo a tinta preta; papel branco, timbrado: "MUNICIPALIDADE DE SÃO PAULO | PROCURADORIA FISCAL": f. 1-5, margens verticais impressas em vermelho: f. 1-5, filigrana: "SELECTED BOND EXTRA STRONG": f. 1-5; 8 folhas; 32,5 x 22,0 cm, com variação em mm; f. 4: 1 furo; vinco; sinais de fungo; furo de grampeador na margem esquerda; f. 2, 5: manchas de tinta; f. 1-5: escrita no verso; f. 6-8: escrita no anverso; rasuras a tinta preta; f. 1: capa improvisada com título, gênero e assinatura a tinta preta: “"Quiséra amar-te, mas não tenho tempo' (poemas) | Fernando Mendes de Almeida.”; fólios numerados pela pesquisa: (1)-(8).

O conjunto de ms apresenta os títulos:

Madrigal indecoroso:

Data abaixo do título: "(1935)".

Notas MA a lápis preto: sugestão de substituição e comentário: "Gosto muito".

Rio-Santo:

Data ao lado do título: "(1936)".

Nota MA a lápis preto: comentário: "Não entendo bem este poema. Ou não | sinto...". 
Ode:

Data ao lado do título: "(1937)".

Notas MA a lápis preto: sugestão de substituição.

Soneto biografico:

Data ao lado do título: "(1939)"; folha numerada pelo escritor: 1.

Nota MA a lápis preto: "Ficou bem milhor. Mas aca- | bar com uma simples enumeração, | não sei, ficou pau, depois de conhecer a | outra versão. Do terceto final da outra | versão aí não gosto do "Oh" e do ultimo | verso que é trocadilhesco como lindo $2^{\circ}$ verso".

Balada da colina:

Data: f. 3: "(1939)"; folhas numeradas pelo escritor: 2-3.

Nota MA a lápis preto: comentários: f. 1: em relação à $1^{\mathrm{a}}$ estrofe: "milhor", f. 2: "gosto mais da $1^{\circ}$ versão deste II", f. 3: "(Sinto faltarem certos versos bonitos $\mid$ da $1^{\text {a }}$ versão deste III" e "Acho excelente esta balada. A | II parte é admirável”.

Notas da pesquisa:

1. Ms na vertente Mário de Andrade mentor.

2. Ms apresentados a MA em 1939, quando FeMA trabalhava no Departamento de Cultura da Municipalidade de São Paulo.

3. Na carta a MA de [São Paulo, nov. 1939?], o poeta refere-se à criação de Balada da colina e dos poemas do conjunto "Quiséra amar-te, mas não tenho tempo". (Ref.: série Correspondência Mário de Andrade - sub-série Correspondência passiva; n 163)

\section{Estudo genético:}

1. Balada da colina; Soneto biografico; Madrigal indecoroso; Rio-Santo apresentam 2 versões. A versão do ms acima classificado, a primeira enviada a MA, foi considerada A pela pesquisa. A análise documentária MA - MOE, 18, mostra neste catálogo a segunda versão, B, encaminhada a MA. Soneto biografico teve o título substituído na versão B por Manifesto inacabado; Madrigal indecoroso tornou-se Madrigal tôsco.

2. O estabelecimento da seqüência na escritura de Madrigal indecoroso, versão A, para Madrigal tôsco, versão B, apoiou-se no confronto de duas Notas MA vinculadas à modificação feita por FeMA no poema: na versão A, a Nota MA no v. 7 sugere a substituição de "encontro-vos" por "alegro-me"; na versão B está incorporada a substituição proposta e a Nota MA: "milhor".

3. Balada da colina e Soneto biografico possuem 2 etapas na escritura: a-a $a_{1}$ :

a: autógrafo completo;

$\mathrm{a}_{1}$ : rasuras a tinta preta.

4. Madrigal indecoroso e Rio-Santo mostram 1 etapa na escritura. 


\section{MA - MOE, 18}

ALMEIDA, Fernando Mendes (Fernando Henriques Mendes de Almeida, 1909-1968)

18. Poemas da sacada; poesia (MAm)

[São Paulo], 1939

Datiloscrito, cópia carbono azul; papel branco timbrado da Municipalidade de São Paulo; 7 folhas; 32,7 x $22 \mathrm{~cm}$; vincos; sinais de fungo; furos de grampeador; f. 8: furo na margem esquerda e rasgamento na margem superior; escrita no verso; rasuras a máquina e a tinta preta; f. 1: capa: com carimbo roxo no anverso e no verso: "Fernando Mendes de Almeida", data, título e autoria a tinta preta: "1939 | Poemas da sacada | por | Fernando Mendes de | Almeida" e bilhete de FeMA a MA; fólios numerados pela pesquisa: (1)-8. Notas MA.

Bilhete na capa do ms:

[São Paulo, post. 24 nov. 1939], assinado: "Fernando", forma de tratamento: "Caro Mario"; autógrafo a lápis preto; escrita no anverso e no verso: “[...] envio-lhe estes poemas. Parece que $\mid$ careço de estriquinina nas tetas $\mid$ poéticas. Em todo o $\mid$ caso, acho milhor o $1^{\circ}$ exemplo 'Balada da colina'".

(Ref. cruzada: série Correspondência Mário de Andrade - sub-série Correspondência passiva; MA-C-CPL, n' 162 )

O conjunto de ms apresenta os títulos:

Balada da colina:

Notas MA a lápis preto: f. 2: correção e sugestão de substituição.

Manifesto do inacabado:

Nota MA a lápis preto: sugestão de substituição.

Madrigal tôsco:

Nota MA: a lápis preto: comentário ao v. 6: "milhor".

Rio - Santo, Nas ondas do tedio, Capitulos de historia interior, Óde:

Nota MA a lápis preto: correção.

No sossego isolito do pensamento...

Notas da pesquisa:

1. Ms na vertente Mário de Andrade mentor.

2. Os títulos no ms pertencem ao projeto de FeMA, o livro Poemas da sacada. Na carta de FeMA a MA que, em 26 de janeiro de1940, acompanha o ms dos poemas "Ceu e terra parados,", "Ternura de andar de ramo em ramo" e "O ceu está de barba. Banhou-se todo o vale." encontra-se a explicação para o título Poemas da sacada. (V. MA-MOE, 19, nota 2).

3. Em 1940 FeMA envia a MA outros ms que fazem parte do projetado livro Poemas da sacada (V. MA - MOE, 19). 
4. Em carta a MA, [São Paulo, nov. 1939?], FeMA menciona a criação de Balada da Colina, poema que acompanhou o conjunto de ms acima registrado. (Ref.: série Correspondência Mário de Andrade - sub-série Correspondência passiva; MA-C-CPL, $\left.\mathrm{n}^{\mathrm{o}} 163\right)$

Estudo genético:

1. As versões dos textos estão classificadas conforme aparecem no arquivo MA.

2. Os poemas Nas ondas do tedio, Capitulos de historia interior, Óde; No sossego insolito do pensamento... apresentam-se em uma única versão, A.

3. Os poemas Balada da colina, Manifesto do inacabado, Madrigal tôsco, Rio - Santo apresentam duas versões. O ms acima registrado traz a segunda versão, B, enviada a MA. (V. análise documentária, MA - MOE, 17, da versão anterior, A). Manifesto inacabado e Madrigal tôsco têm na versão A os títulos Soneto biografico e Madrigal indecoroso, respectivamente. Há entre ambas versões.

4. O estabelecimento da seqüência na escritura de Madrigal indecoroso, da versão A, para Madrigal tôsco, versão B, apoiou-se no confronto de duas Notas MA vinculadas à modificação feita por FeMA no poema: na versão A, a Nota MA, no v. 7, sugere a substituição de "encontro-vos" por "alegro-me"; na versão B está incorporada a substituição proposta e a Nota MA considera: "milhor".

5. Nas ondas do tedio mostra 2 etapas na escrita: $\mathrm{a}-\mathrm{a}_{1}$ :

a: datiloscrito completo;

$\mathrm{a}_{1}$ : rasuras a máquina.

6. Capitulos de historia interior, Óde e No sossego isolito do pensamento... mostram 3 etapas na escrita: $a-a_{1}-a_{2}$ :

a: datiloscrito completo;

$\mathrm{a}_{1}$ : rasuras a máquina;

$\mathrm{a}_{2:}$ rasuras a tinta preta.

7. Rio - Santo mostra 2 etapas na escrita: $\mathrm{b}-\mathrm{b}_{1}$ :

b: datiloscrito completo;

$\mathrm{b}_{1}$ : rasuras a máquina.

8. Balada da colina; Manifesto do inacabado; Madrigal tôsco mostram 3 etapas na escrita: $b-b_{1}-b_{2}$ :

b: datiloscrito completo;

$\mathrm{b}_{1:}$ rasuras a máquina;

$\mathrm{b}_{2:}$ rasuras a tinta preta.

\section{MA - MOE, 19}

ALMEIDA, Fernando Mendes (Fernando Henriques Mendes de Almeida, 1909-1968)

19. "Ceu e terra parados,"; "Ternura de andar de ramo em ramo"; "O ceu está de barba. Banhou-se todo o vale."; poesia (MAm)

São Paulo, 26 fev. 1940

Poemas enviados por FeMA a MA no corpo da carta datada de "S.P. 26/2/40"; assinatura a lápis preto: "Fernão"; forma de tratamento: "Mario-Raul,"; datiloscrito original, fita azul; papel branco timbrado da Municipalidade de São Paulo, filigrana; 1 
folha; 31,5/31,9 x $22 \mathrm{~cm}$; vincos; sinais de fungo; escrita no verso; rasuras a máquina; fólio numerado pela pesquisa: (1)

(Ref. cruzada: Correspondência Mário de Andrade - sub-série Correspondência passiva; MA-C- CPMVA, nº 167)

Notas da pesquisa:

1. Ms na vertente Mário de Andrade mentor.

2. Na carta que inclui o ms está a razão do título: "Quando o trabalho desafogar um bocado, mandarei poemas: 'Os da sacada', assim chamados | porque vão sendo feitos na repartição, antes da horinha do café de uma hora da tarde. | Eu queria mandar tudo já, porém, o Saia está para ir ver a gente em casa e, por isso, | levei os manuscritos para a Vila Mariana. O poema inicial começa assim:". A sacada frequentada pertencia ao Departamento de Cultura que funcionava na casa que fora da Marquesa de Santos, no centro de São Paulo. O poeta morava na Vila Mariana, bairro de São Paulo.

3. Poemas da sacada foram enviados a MA em duas séries, em 1939 e 1940 (V. MAMOE, 18 e MA-MOE, 20).

\section{Estudo genético:}

1. A classificação contempla os ms no arquivo MA.

2. "O ceu está de barba. Banhou-se todo o vale" apresenta-se em uma única versão A.

3. "Ceu e terra parados" apresenta 2 versões, enviadas separadamente a MA. A acima registrada, A, foi encaminhada primeiramente; a segunda está no conjunto de 1940 de Poemas da sacada (V. análise documentária da versão B, MA - MOE, 20). A única variante entre elas é o acréscimo do título Ceu e terra parados... na versão B.

4. "Ternura de andar de ramo em ramo", versão A, foi incorporado a Miniaturas talvez, que se encontra no conjunto de Poemas da sacada de 1940 (V. MA - MOE, 20).

5. A versão A dos três poemas mostra 1 etapa na escritura.

\section{MA - MOE, 20}

ALMEIDA, Fernando Mendes (Fernando Henriques Mendes de Almeida, 1909-1968)

20. Poemas da sacada; poesia (MAm)

[São Paulo], 1940

Datiloscrito, cópia carbono azul: f. 2-6; autógrafo a lápis preto: f. 6; autógrafo a tinta preta: f. 6-10; papel branco timbrado da Municipalidade de São Paulo, filigrana; 10 folhas; 32,5 x $22 \mathrm{~cm}$; furo de grampeador; vincos; sinais de fungo; escrita no verso; $\mathrm{f}$. 1: capa com data e assinatura em datiloscrito e : "Poemas da sacada | 1940 | Fernando Mendes de Almeida." e bilhete de FeMA a MA; rasuras a máquina, a tinta preta e a tinta preta; poemas numerados pelo escritor: 1-4, 6-8; folhas numeradas pelo escritor: 19; fólios numerados pela pesquisa: (1)-(10). Notas MA.

Bilhete: assinado: "F"; forma de tratamento: "Mario."; autógrafo a tinta preta; escrita no verso. 
O conjunto de ms apresenta os títulos:

Dona Infanta

Ceu e terra parados...:

Nota MA a lápis vermelho: sinal na margem esquerda: "X".

\section{Especial}

Miniaturas talvez:

Nota MA a lápis azul: f. 2: grifo em palavra na estrofe 11, v. 1: "tochas", e comentário a respeito: "Pesado como | imagem".

Evocação de Pandora e Forde:

"A daninha herva que cultivo"

"Olhas. Tão claro e puro":

Notas MA a lápis azul: f. 1-2: sugestão de substituição.

"Por uma janela, bem que não me lembre":

Nota MA a lápis azul na f. 1:grifo destacando o v. 9, palavras circundadas e comentário.

Notas da pesquisa:

1. Ms na vertente Mário de Andrade mentor.

2. No bilhete, FeMA escreve: "Mario, | Vão mais êstes e um | retratinho de Angela | Maria. | Abraços meus | e da Nair | F.”. Na série Fotografias do Arquivo Mário de Andrade, no IEB-USP, está o instantâneo da filha mais velha do poeta.

3. FeMA enviou a MA duas séries de Poemas da sacada. Os acima registrados fazem parte da segunda série; a primeira foi encaminhada em 1939 (V. MA - MOE, 18).

4. Na carta de FeMA a MA, em 26 de fevereiro de 1940, está o relato da criação dos Poemas da sacada: "Quando o trabalho desafogar um bocado, mandarei poemas: 'Os da sacada', assim chamados | porque vão sendo feitos na repartição, antes da horinha do café de uma hora da tarde. | Eu queria mandar tudo já, porém, o Saia está para ir ver a gente em casa e, por isso, | levei os manuscritos para a Vila Mariana". No corpo da carta encontram-se os poemas "Ceu e terra parados,"; "Ternura de andar de ramo em ramo"; " "O ceu está de barba. Banhou-se todo o vale.", com análise documentária neste catálogo: MA-MOE, 19. (Ref. da carta: série Correspondência Mário de Andrade - subsérie Correspondência passiva; MA-C- CPMVA, $\mathrm{n}^{\circ}$ 167)

5. Em carta a MA, de São Paulo, 13 de março de 1940, FeMA responde os comentários do amigo sobre "Os poemas da sacada" (Ref.: Correspondência Mário de Andrade - subsérie Correspondência passiva; MA-C-CPL, nº 168). 
Estudo genético:

1. As versões dos textos estão classificadas conforme aparecem no arquivo MA.

2. Ceu e terra parados... apresenta 2 versões; a primeira, A, foi enviada a MA em 26 de fevereiro de 1940 (V. MA-MOE, 19). A única variante entre elas é o acréscimo de título na versão $B$. A versão B mostra 2 etapas na escritura: $b-b_{1}$ :

b: datiloscrito completo;

$\mathrm{b}_{1}$ : rasuras a máquina.

3. Os demais poemas apresentam-se em uma única versão, A.

4. "Por uma janela, bem que não me lembre" mostra 1 etapa na escritura.

5. Miniaturas talvez e Evocação de Pandora e Forde mostram 2 etapas na escritura: a-a ${ }_{1}$ : a: datiloscrito completo;

$\mathrm{a}_{1}$ : rasuras a máquina.

6. "Olhas. Tão claro e puro" mostra 2 etapas na escritura: a-a $a_{1}$ :

a: datiloscrito completo;

$\mathrm{a}_{1}$ : rasuras a a lápis.

7. Dona Infanta e Especial mostra 3 etapas na escritura a-a $a_{1}-a_{2}$ :

a: datiloscrito completo;

$\mathrm{a}_{1}$ : rasuras a máquina;

$\mathrm{a}_{2}$ : rasuras a tinta preta.

8. "A daninha herva que cultivo" mostra 4 etapas na escritura: $a-a_{1}-a_{2}-a_{3}$ :

a: datiloscrito completo;

$\mathrm{a}_{1}$ : rasuras a máquina;

$\mathrm{a}_{2}$ : autógrafo a lápis preto;

$\mathrm{a}_{3}$ : autógrafo a tinta preta.

9. Miniaturas talvez incorporou como estrofe o poema "Ternura de andar de ramo em ramo", enviado a MA em 26 de fevereiro de 1940 (V. análise documentária de "Ternura de andar de ramo em ramo", MA - MOE, 19).

\section{MA - MOE, 21}

ALMEIDA, Francisco Martins de

21. Escrava que não é Isaura; crítica (MAm)

Belo Horizonte, [jun. 1925 ?]

Datiloscrito, cópia carbono roxo; papel branco; 3 folhas; 32,9 x 22/22,2 cm; margem esquerda irregular; vincos; sinais de fungos; escrita no anverso; folhas numeradas a tinta preta: $1-3$; f. 3 : local e assinatura em autógrafo a tinta preta: "Bello Horizonte | Martins de Almeida"; rasuras a máquina, a tinta preta e a tinta azul; fólios numerados pela pesquisa: (1)-(3).

Notas da pesquisa:

1. Ms na vertente Mário de Andrade mentor.

2. Data do ms atestada com base na carta que FrMA enviou a MA em [jun. 1925], acompanhada do artigo sobre o livro do destinatário, A escrava que não é Isaura, recém publicado. A carta refere-se a outra cópia do artigo remetida à Revista do Brasil, 
do Rio de Janeiro. (Série Correspondência Mário de Andrade - sub-série Correspondência passiva; MA-C-CPL, $n^{\circ} 183$ )

3. Escrevendo a MA, de Belo Horizonte, em 2 de julho de 1925, FrMA constata sua impossibilidade de repetir o artigo na Revista, periódico modernista de Belo Horizonte: "Não publiquei o artigo | que escrevi sobre o | seu livro porque a nossa | secção não comportava | aquella explanação e | o nosso camarada E. | Moura já tinha dado | uma noticia.". (Série Correspondência Mário de Andrade - sub-série Correspondência passiva; MA-C-CPL, ${ }^{\circ} 184$ )

4. O primeiro encontro de FrMA com MA ocorreu em abril de 1924, quando Martins de Almeida, Pedro Nava, Emílio Moura e Carlos Drummond de Andrade foram até o Grande Hotel de Belo Horizonte para ali conhecer Mário de Andrade. Ocorria naquele momento a famosa "Viagem de descoberta do Brasil", quando os modernistas de São Paulo Mário de Andrade, Oswald de Andrade e Tarsila do Amaral, com sua mecenas Olívia Guedes Penteado e o genro dela, Gofredo da Silva Teles, percorreram as cidades históricas de Minas Gerais acompanhando o poeta da vanguarda francesa Blaise Cendrars.

\section{Estudo genético:}

1. No arquivo MA o texto apresenta-se em uma única versão, A, o datiloscrito em cópia carbono que mostra 4 etapas na escritura: $a-a_{1}-a_{2}-a_{3}$

a: datiloscrito completo;

$\mathrm{a}_{1}$ : rasuras a máquina;

$\mathrm{a}_{2}-\mathrm{a}_{3}$ : rasuras a tinta preta e a tinta azul, sem possibilidade de se definir a ordem dessas duas etapas

\section{MA - MOE, 22}

\section{ALMEIDA, Francisco Martins de}

22. Desabafo; Impressão; Na procuradoria geral; poesia (MAm)

[Belo Horizonte, 1926]

Autógrafo a tinta preta; papel branco; 3 folhas; 32,1 x 21,7/ $22 \mathrm{~cm}$; vincos; sinais de fungo; f. 1: rasgamentos e sinais de amassado na margem superior, rasgamento na margem esquerda e tinta borrada; escrita no anverso; rasuras a tinta preta; f. 3: dedicatória: "Ao promotor de justiça Ribeiro Couto"; fólios numerados pela pesquisa: (1)-(3). Nota MA

\section{Desabafo:}

Nota MA a lápis preto: f. 1 no verso: "Martins de Almeida".

Notas da pesquisa:

1. Ms na vertente Mário de Andrade mentor.

2. Local e data do ms atestados com base na carta de FrMA a MA, de Belo Horizonte, 10 de outubro de 1926: "Estou meti-| do numa porção de | servicinhos e envol- |vido em cavações | com o governo. Promo- |vi até banquetes | oficiais, o que deu lo- | gar a um poema | que lhe envio. Ma- |rio, eu acho que não | sou poeta. Ha coisa | de um mez e 
pou- |co senti necessida- |de de fazer versos | e poetei. São as mi- |nhas primeiras produções poéticas. A | que eu levo um | pouco a sério é | Desabafo que apezar | de seu caráter circunstan | cial me parece ter mais | poesia. | Me esculhambe a vontade." (Série Correspondência Mário de Andrade - sub-série Correspondência passiva; MA-C-CPL, $\left.\mathrm{n}^{\mathrm{o}} 198\right)$

3. O primeiro encontro de FrMA com MA ocorreu em abril de 1924 (V. MA-MOE, 21, nota 4$)$.

4. A leitura da correspondência trocada entre o escritor mineiro e MA, indica que, além dos poemas acima classificados e do artigo Escrava que não é Isaura (MA - MOE, 21), vieram outros textos de FrMA que não mais se encontram no Arquivo Mário de Andrade.

Estudo genético:

1. O ms apresenta-se em uma única versão, A, que mostra 2 etapas na escritura: a-a $a_{1}$ : a: autógrafo completo;

$\mathrm{a}_{1}$ : rasuras a tinta preta.

MA - MOE, 23

[ALMEIDA, Renato] (1895-1981)

23. "Quase tudo que se fes na época colonial foi de carater religioso"; ensaio musicológico (MAd)

[Rio de Janeiro, ant. 1942]

Autógrafo a tinta preta; papel branco, pautado, margens em linhas verticais vermelhas, timbrado: "SECRETARIA DE ESTADO DAS RELAÇÕES EXTERIORES", logotipo, filigrana: "MINISTERIO DAS RELAÇÕES EXTERIORES; 1 folha; $32,5 \mathrm{x}$ $22,3 \mathrm{~cm}$; vincos; sinais de fungos; furos para arquivamento; escrita no anverso e no verso; rasuras a tinta preta; fólio numerado pela pesquisa: (1). Nota $\mathrm{T}$ a lápis preto: $\mathrm{B} / \mathrm{II} / \mathrm{e} / 4$.

Notas da pesquisa:

1. Ms na vertente Mário de Andrade no diálogo interpares.

2. Autoria atestada com base na comparação entre: a) caligrafia de ReA neste ms e nas cartas a MA; b) o texto deste ms e o texto nas obras de ALMEIDA, Renato. História da música brasileira. Rio de Janeiro, F Briguiet, 1926 e História da música brasileira. $2^{\mathrm{a}}$ ed., correta e aumentada. Rio de Janeiro, F. Briguiet, 1942. Como o texto do ms não está na $1^{\mathrm{a}}$ edição, e sim na $2^{\mathrm{a}}$, com variantes, pode-se atestar a data como anterior a 1942, e o ms como fragmento de uma versão.

3. Na biblioteca MA há um exemplar da $1^{\mathrm{a}}$ edição, com anotações de leitura de MA, e dois exemplares da $2^{a}$ edição, um deles em tiragem especial, com a dedicatória na folha de ante-rosto: "Mário, você sabe quanto | the devo êste livro, | Renato Almeida | Rio, 25 fev. 42."; o outro exemplar apresenta anotações MA a lápis preto.

4. A Nota T no ms foi feita pela equipe de pesquisadores que, coordenada pelo Prof. Dr. Antonio Cândido de Mello e Souza, realizou o tombamento da biblioteca e o registro da marginalia de MA, entre 1964 a 1968. A nota identifica o livro na biblioteca MA. (V.: 
LOPEZ, Telê Ancona. "A biblioteca de Mário de Andrade : seara e celeiro da criação". In: Zular, Roberto, org. Criação em processo: ensaios de crítica genética. São Paulo, Iluminuras, 2002, p. 45-72)

Estudo genético:

1. No arquivo MA o texto apresenta-se em uma única versão, $A$, fragmento de esboço de versão; mostra 2 etapas na escritura: $\mathrm{a}-\mathrm{a}_{1}$ :

a: autógrafo completo;

$\mathrm{a}_{1}$ : rasuras a tinta preta.

2. A versão A, confrontada com trecho do capítulo VII, "A música no Brasil do século XVI ao século XVIII", p. 296-297, da versão B, isto é, a da $2^{\mathrm{a}}$ ed. de História da música brasileira (Rio de Janeiro, F. Briguiet, 1942) mostra variantes.

\section{MA - MOE, 24}

ALMEIDA, Tácito de (1899-1940)

24. Desenho; O abraço...; Pobreza; Serenidade; Sourcier; poesia (MAd)

[São Paulo, ant. 1923]

Datiloscrito, cópia carbono roxo; papel verde, filigrana: "old holyoke bond"; 5 folhas; 28,2 x 21,6 cm; vinco; sinais de fungo; escrita no anverso; fólios numerados pela pesquisa: (1)-(5).

Notas da pesquisa:

1. Ms na vertente Mário de Andrade no diálogo interpares.

2. A obra poética de TA, com exceção dos poemas publicados em Klaxon sobre o pseudônimo Carlos Alberto de Araújo, permaneceu inédita até a edição póstuma: Túnel e poesias modernistas - 1922/23. Estabelecimento do texto e estudo "Tácito tempo de passagem" de Telê Ancona Lopez. São Paulo, Art Editora, 1987. A preparação desse livro utilizou exclusivamente os ms do arquivo de TA.

3. A data do ms foi atestada com base no estudo citado. Segundo a preparadora da edição, TA deteve sua produção poética em 1923. Publicou, em 1922, na revista do modernismo paulista, Klaxon, os poemas "Tempestade" (n' 2, 15 jun. 1922), "A mesma tempestade" (n 4, 15 ago. 1922), "Salvar" (n' 6, 15 out. 1922) e "Paz universal" ( ${ }^{\circ}$ 8/9, dez. 1922/jan. 1923).

4. Desenho e Sourcier estão em Túnel e poesias modernistas - 1922/23 (ed. cit.).

Estudo genético:

1. No arquivo MA os poemas apresentam-se em uma única versão, A, o datiloscrito em cópia carbono que mostra 1 etapa na escritura. 


\section{MA - MOE, 25}

ALMEIDA, Tácito de (1899-1940)

25. Alegria; "Eu desprezo a minha vida!"; Combate; Dirigiveis; Incendio universal; Insomnia; Kermesse; Luz!; Novo mundo; São Paulo; poesia (MAd)

[São Paulo, ant. 1923]

Datiloscrito original, fita preta e vermelha; papel branco, papel branco, filigrana: "Brazil bond": f. 1, 3-11; 13 folhas; f. 1, 3-11: 33,2 x 21,6/21,7 cm, f. 2, 12-13: 25,2 x 20,6 cm; vinco; sinais de fungo; f. 1: rasgamentos na borda esquerda e 1 furo; f. 8-9: estrofes numeradas pelo escritor: "I", "II"; f. 11: manchas de tinta no verso; escrita no anverso; rasura a tinta preta; fólios numerados pela pesquisa: (1)-(1) (3). Notas MA.

Alegria:

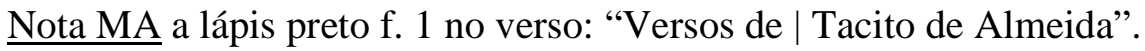

"Eu desprezo a minha vida!":

Nota MA a lápis vermelho: f. 2: marcação na margem esquerda: "X".

Notas da pesquisa:

1. Ms na vertente Mário de Andrade no diálogo interpares.

2. Data atestada com base estudo de Telê Ancona Lopez citado (V. MA-MOE, 24, notas 2-3).

3. Todos os poemas do ms acima registrado estão publicados em Túnel e poesias modernistas - 1922/23 (ed. cit.).

\section{Estudo genético:}

1. No arquivo MA os textos apresentam-se em uma única versão, A, passada a limpo no datiloscrito que mostra nos poemas Alegria, "Eu desprezo a minha vida!", Combate, Dirigiveis, Kermesse e Novo mundo 1 etapa na escritura, e nos poemas Incendio universal, Insomnia, Luz! e São Paulo 2 etapas na escritura: a-a $\mathrm{a}_{1}$ :

a: datiloscrito completo;

$\mathrm{a}_{1}$ : rasuras a tinta preta.

\section{MA - MOE, 26}

ALMEIDA, Tácito de (1899-1940)

26. As tardes brancas; poesia (MAd)

[São Paulo, ant. 1923]

Datiloscrito, cópia carbono azul; papel branco; 2 folhas; 27,9 x $22,1 \mathrm{~cm}$; f. 1: rasgamentos na borda direita, f. 2: rasgamentos nas bordas superior, inferior e direita; vincos; sinais de fungo; escrita no anverso; assinatura a tinta preta: "Tacito de Almeida"; rasuras a máquina; fólios numerados pela pesquisa: (1)-(2). Nota TA em datiloscrito na f. 2: "(Do livro "A planta flexivel")". 
Notas da pesquisa:

1. Ms na vertente Mário de Andrade no diálogo interpares.

2. Data atestada com base estudo de Telê Ancona Lopez citado (V. MA-MOE, 24, notas 2-3).

3. O poema As tardes brancas foi publicado em Túnel e poesias modernistas - 1922/23 (ed. cit.).

4. A Nota TA indica que o poema pertence ao livro inédito A planta flexível.

\section{Estudo genético:}

1. O ms apresenta-se em uma única versão, A, que mostra 2 etapas na escritura: a-a $\mathrm{a}_{1}$ : a: datiloscrito completo;

$\mathrm{a}_{1}$ : rasuras a máquina.

\section{MA - MOE, 27}

\section{ALPHONSUS, João (1901-1944)}

27. União 15 de novembro; poesia (MAm)

Belo Horizonte, 1 dez. 1926

Datiloscrito, cópia carbono azul; papel branco, bordas esquerda e inferior irregulares; 1 folha; 22,7 x 16,3 cm; sinais de fungo; vincos; rasgamento na borda esquerda; escrita no anverso; data, local e assinatura a tinta preta: "1-12-926 | João Alphonsus"; dedicatória em autógrafo a tinta preta: "(pro Carlos Drumond)"; rasuras a máquina e a tinta preta; fólio numerado pela pesquisa: (1). Nota JAlp a tinta preta na margem esquerda: "(Desculpe. Copiada afobadamente)".

Notas da pesquisa:

1. Ms na vertente Mário de Andrade mentor.

2. Na carta a MA de Belo Horizonte, em 7 de dezembro de 1926, JAlp escreveu: "Poesia propria- | mente dita quanto pior melhor. Os meus piores versos metrificados têm encon- | trado tantos admiradores que é mesmo um desgosto.[...] Faço vesos por- | que sinto precisão disso e embora ás vezes escrevo prosa, minha ambição | maior é ser poeta, poetando 'como quem vive' sem crear methodos previos in- $\mid$ tenções lyricas prestabelecidas nem nada. Confesso aqui pra V. que meus ver- $\mid$ sos mesmo quando reconheço elles muito ruins me botam contente e lépido. | Ao contrário de outros poetas raramente rasgo elles e guardo-os não pra pu- | blicar mas pra reler de vez em quando como pedaços tem horas que detesta- | veis de mim mesmo. V. conclua o que quizer mas eu era assim e hoje es- | tou assim. Frutos talvez duma incultura bem regularzinha" (Ref.: série Correspondência Mário de Andrade - sub-série Correspondência passiva; MA-C- CPL, $\mathrm{n}^{\circ}$ 372). 
Estudo genético:

1. No arquivo MA os poemas apresentam-se em uma única versão, A, datiloscrito em cópia carbono que mostra 3 etapas na escritura: $a-a_{1}-a_{2}$ :

a: datiloscrito completo;

$\mathrm{a}_{1}$ : rasuras a máquina;

$\mathrm{a}_{2}$ : rasuras a tinta preta.

\section{MA - MOE, 28-30}

ALVARENGA, Oneida (Oneida Paolielo Alvarenga 1911-1984)

28. Cantiga; poesia (MAm)

[Varginha, jun. 1932]

Autógrafo a tinta preta; papel almaço, branco, pautado; 2 folhas; $32,8 \times 22 \mathrm{~cm}$; sinais de fungo; vincos; escrita no anverso; fólios numerados pela pesquisa: (1)-(2).

Notas MA: f. 1: a lápis preto: comentários: geral: "Falta crescendo. | Pelo meio da serie devia | vir um poema exaltadis- | simo, cheio de gritos.", "Idea otima", à primeira estrofe: "otimo", à segunda estrofe: "ruim"; a lápis vermelho: grifos em palavras.

29. "Queimada pelo sol, desvairada"; "Amor novo da vida"; "Comecei a entender o amor da vida,"; "Tombos, decepções"; "Doçura"; "Somos feitos"; "Andrajosa, ulcerada, miseravel?"; "Vento que corropia"; poesia (MAm)

[Varginha, jun. 1932];

Autógrafo a tinta preta; papel almaço, branco, pautado, 8 folhas; 32,8 × $22 \mathrm{~cm}$; sinais de fungo; vincos; escrita no anverso; poemas numerados pela escritora: "I"-"VIII"; fólios numerados pela pesquisa: (1)-8)

"Queimada pelo sol, desvairada":

Nota MA a lápis preto na margem superior: comentário: "Elogio da Vida | (é horrivel. | 'A menina boba' 'A menina louca' | 'Potranca' não ter medo | das palavras fortemente objeti- | vas. São as que mais dão a | sensação viva. E pro | poema, o titulo tem | que ser vivas".

"Amor novo da vida":

Notas MA a lápis preto: comentários e sugestões de substituição.

"Comecei a entender o amor da vida,":

Nota MA a lápis preto: à margem esquerda: sugestão de substituição, embaixo do poema: "(aqui o poema VIII)".

"Tombos, decepções":

Notas MA a lápis preto: comentários e sugestões de substituição.

"Doçura":

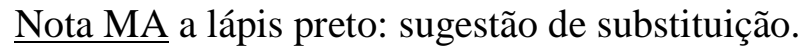


"Andrajosa, ulcerada, miseravel?":

Nota MA a lápis preto na margem esquerda: comentário ao v. 9 ("estatelada no ar"): "ruim".

"Vento que corropia":

Notas MA a lápis preto: sugestões de substituição na ordem dos poemas, comentários e sugestões de substituição.

30. "Havia só"; "Voltei cansada"; poesia (MAm)

[Varginha, jun. 1932]

Autógrafo a tinta preta; papel almaço, branco, pautado; 3 folhas; $32,8 \times 22 \mathrm{~cm}$; sinais de fungo; vincos; escrita no anverso; poemas numerado pela escritora: "I"-"II"; fólios numerados pela pesquisa: (1)-(3). Notas MA.

"Voltei cansada":

Notas MA a lápis na margem esquerda: comentário e sugestão de substituição.

Notas da pesquisa:

1. Ms na vertente Mário de Andrade mentor.

2. Em fevereiro de1931, OA mudou-se de Varginha (MG) para São Paulo, com a finalidade de estudar piano, em aulas particulares com MA, indicado por quatro amigas, ex-alunas dele; matriculou-se também no Conservatório Dramático e Musical de São Paulo. Em junho de 1932, em uma visita, a mãe de OA mostrou a MA poemas da filha, escritos na adolescência. $O$ professor, que já percebera o grande interesse dela pela literatura, passou a incentivar-lhe a criação poética, ao mesmo tempo que lhe ofereceu orientação intelectual, indicando-lhe leituras de História da Arte, Filosofia, Literatura e Música.

3. OA lembra o início da orientação intelectual e dos exercícios poéticos: "Nas férias de junho de 1932, fui a Varginha com a obrigação aceita de escrever a Mário um relatório semanal dos meus estudos escritos. Destes, a tarefa principal era criar uma série de poemas curtos do tipo formal dos 'Poemas da Amiga' e 'da Negra', que estão no Remate de Males. Meus poemas começaram com a série 'Menina Boba', assim batizada por Mário e que veio a dar o nome a meu único livro de versos publicado". (ANDRADE, Mário de. Mário de Andrade - Oneyda Alvarenga: cartas. Oneyda Alvarenga org. São Paulo, Duas Cidades, 1983, p. 22, nota 3)

4. Local e a data dos ms atestados de acordo com as informações em duas das cartas que a OA enviou de Varginha a MA, em 19 de junho 1932 e $1^{\circ}$ de julho 1932, quando escrevia atendendo solicitação de MA. Na primeira, relata o início da criação dos poemas no ms: "[...] comecei a sua série de poemas sintéticos, que está mas é saindo uma série de asneiras concentradas. Vou levando-a, entretanto, para diante, visto que o senhor me deu pleno direito de fazer tolices à minha vontade. Mandá-la-ei logo que esteja terminada." (Mário de Andrade - Oneyda Alvarenga: cartas. ed. cit., p. 21). Na segunda carta se lê: "Cá estão os versos escritos até agora. Esses não são para o senhor achar graça: são para chorar de desânimo. Pensei em levá-los, em vez de os mandar, para lhe poupar uma resposta longa, que lhe roubaria tempo. Mas matutei bem, e resolvi que iriam assim mesmo, antes que os rasgasse ou queimasse. Naturalmente que o senhor não vai fazer cerimônias comigo; não se amole em comentar minhas bobagens. 
[...] Os versos estão sem batismo. Aquela série de oito jóias vale para mim como um Elogio da vida (que pernoticismo! Os outros dois acho que vão ficar pagãos)." (Mário de Andrade - Oneyda Alvarenga: cartas. ed. cit., p. 27-29)

5. MA rejeita o título Elogio da Vida, dado pela autora à série de oito poemas: "Eu mesma tinha consciência da bobeira do título, como está na minha carta de 1-VII-1932. Como Mário desaprovasse o título, isso me deixou numa absoluta incapacidade de batizar poemas. Só após a morte do amigo ousei criar os títulos: o que antes eu achava incapacidade, era um enorme sentimento de inferioridade. Mas eu não era a única a recorrer aos batismos dele: Manuel Bandeira pedia nomes para o 'Libertinagem', embora acabasse por recusar as sugestões." (Mário de Andrade - Oneyda Alvarenga: cartas. ed. cit., p. 35, nota 5.)

6. As observações de MA sobre Cantiga, o conjunto dos oito poemas e o conjunto dos dois poemas subseqüentes estão na carta por ele dirigida a OA, em 10 jul. 1932 (Mário de Andrade - Oneyda Alvarenga: cartas. ed. cit., p. 31-35). Mário utilizou os comentários marginais, que apôs aos ms, como notas prévias para a carta. OA ao organizar, em 1983, a correpondência recíproca, detém-se neste trecho da missiva de MA: "Porque os seus versos me deram uma alegria enorme. Foi enorme o progresso que você fez, até eu me ria lendo os versos de agora, achando graça na desinvoltura que você ganhou de sopetão, apenas por ter encontrado o caminho das fontes do lirismo.", assim faz para nos trazer, em seguinte nota de rodapé este eclarecimento: "No ponto marcado por esta nota começam as epistolares lições de poética que recebi de Mário, nascidas de versos meus. § Acentuo que entre os muitos ensinos contidos nas cartas que Mário me escreveu, os de poética são importantes, por revelarem o seu modo de trabalhar a matéria lírica: não só a fuga ao banal, a busca da expressão exata e da concisão, mas o segredo maior de todo poeta forte: 'Lembre sempre de ver as coisas por todos os lados'." (Mário de Andrade - Oneyda Alvarenga: cartas. ed. cit., p. 35, nota 3)

7. Os poemas "Queimada pelo sol, desvairada"; "Amor novo da vida"; "Comecei a entender o amor da vida,"; "Tombos, decepções"; "Doçura"; "Andrajosa, ulcerada, miseravel?"; "Vento que corropia"; "Havia só"; "Voltei cansada" estão em ALVARENGA, Oneyda. A Menina Boba. São Paulo, Empresa Gráfica da "Revista dos Tribunais", 1938.

Estudo genético:

1. No arquivo MA os poemas apresentam-se em uma única versão, A, passada a limpo, o autógrafo que mostra uma etapa na escritura

2. Os poemas Cantiga, "Queimada pelo sol, desvairada", "Amor novo da vida", "Comecei a entender o amor da vida,", "Tombos, decepções", "Doçura", "Andrajosa, ulcerada, miseravel?", "Vento que corropia", "Havia só", "Voltei cansada", serão reapresentados a MA em outra versão, B, no caderno A Menina Boba (V. MA-MOE, 31).

3. A versão $A$ foi confrontada com a versão $C$, a do único livro de poesia publicado por Oneyda Alvarenga, A Menina Boba (ed. cit.).

4. Na versão C, os poemas "Amor novo da vida", "Comecei a entender o amor da vida,", "Tombos, decepções", "Doçura", "Andrajosa, ulcerada, miseravel?", "Vento que corropia", "Voltei cansada" apresentam variantes em relação à versão A, resultado da aceitação das Notas MA.

5. O confronto das versões ao lado da análise da correspondência, evidencia uma espécie de co-autoria entre MA e OA nos poemas. 


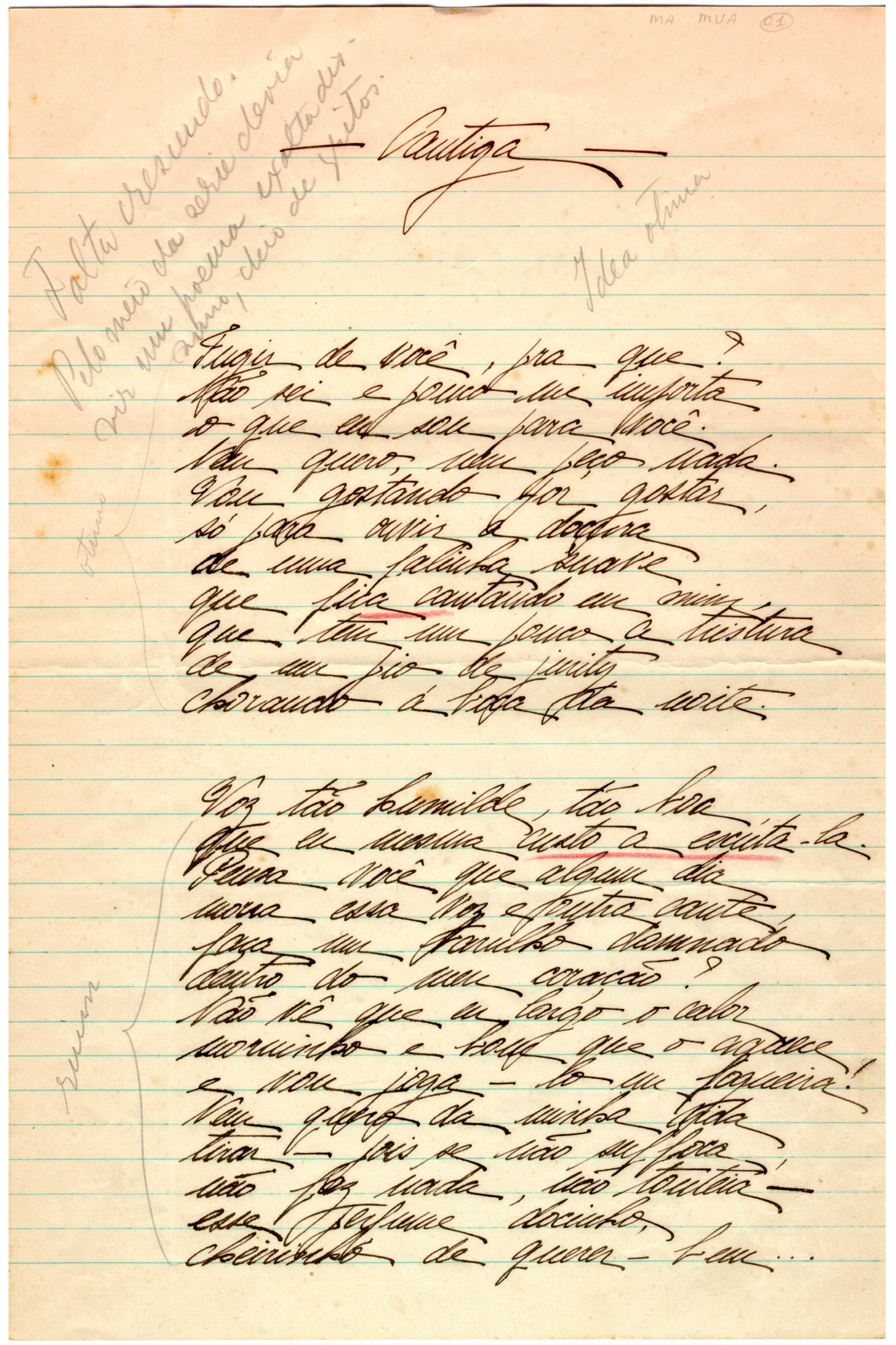


Glogio da Vida

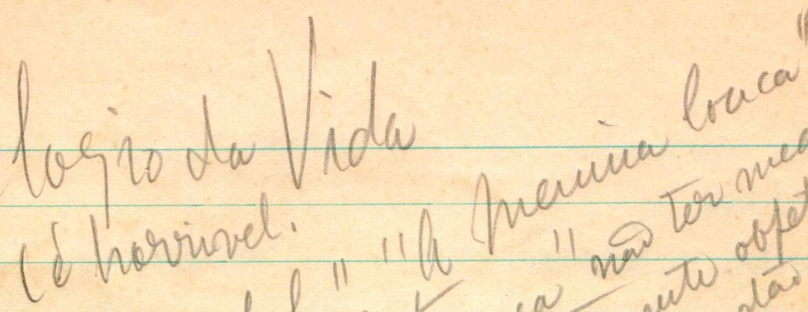

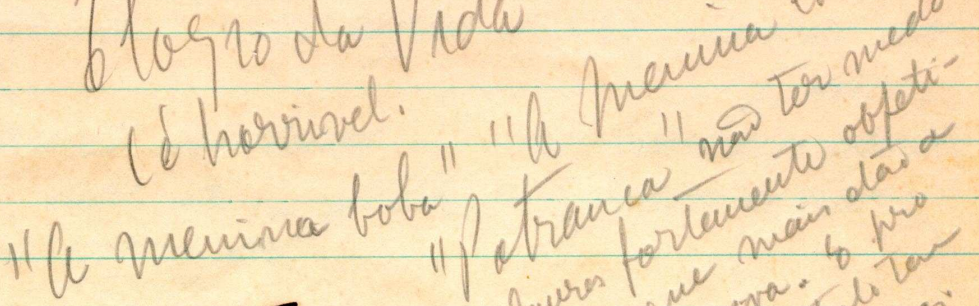

$$
\text { I }
$$

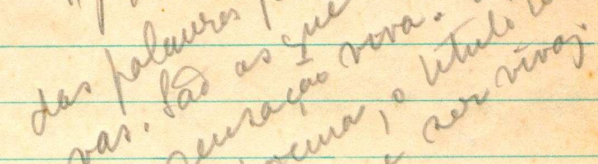

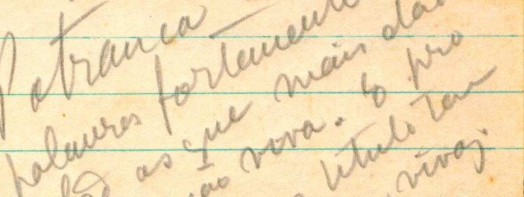
queiuada feb nol, davicinada

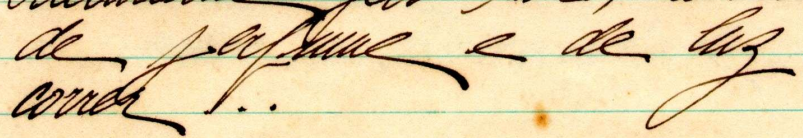

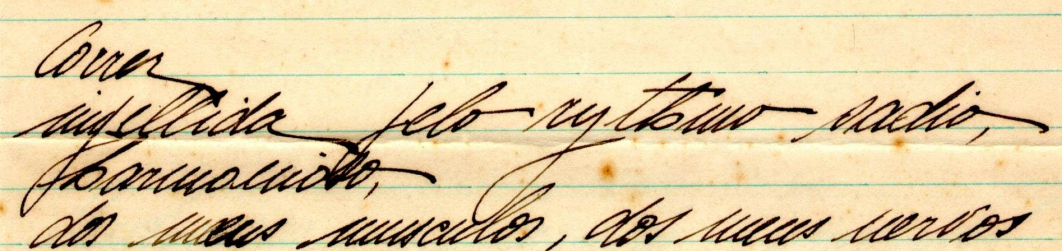
de driate auves...

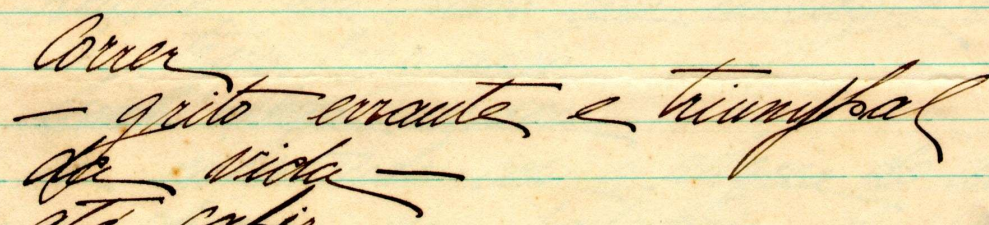

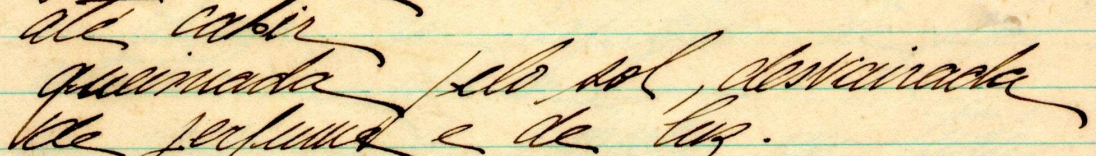
def ferfunde de toy.

$$
\text { II }
$$

Cluov uoto da tick

61 


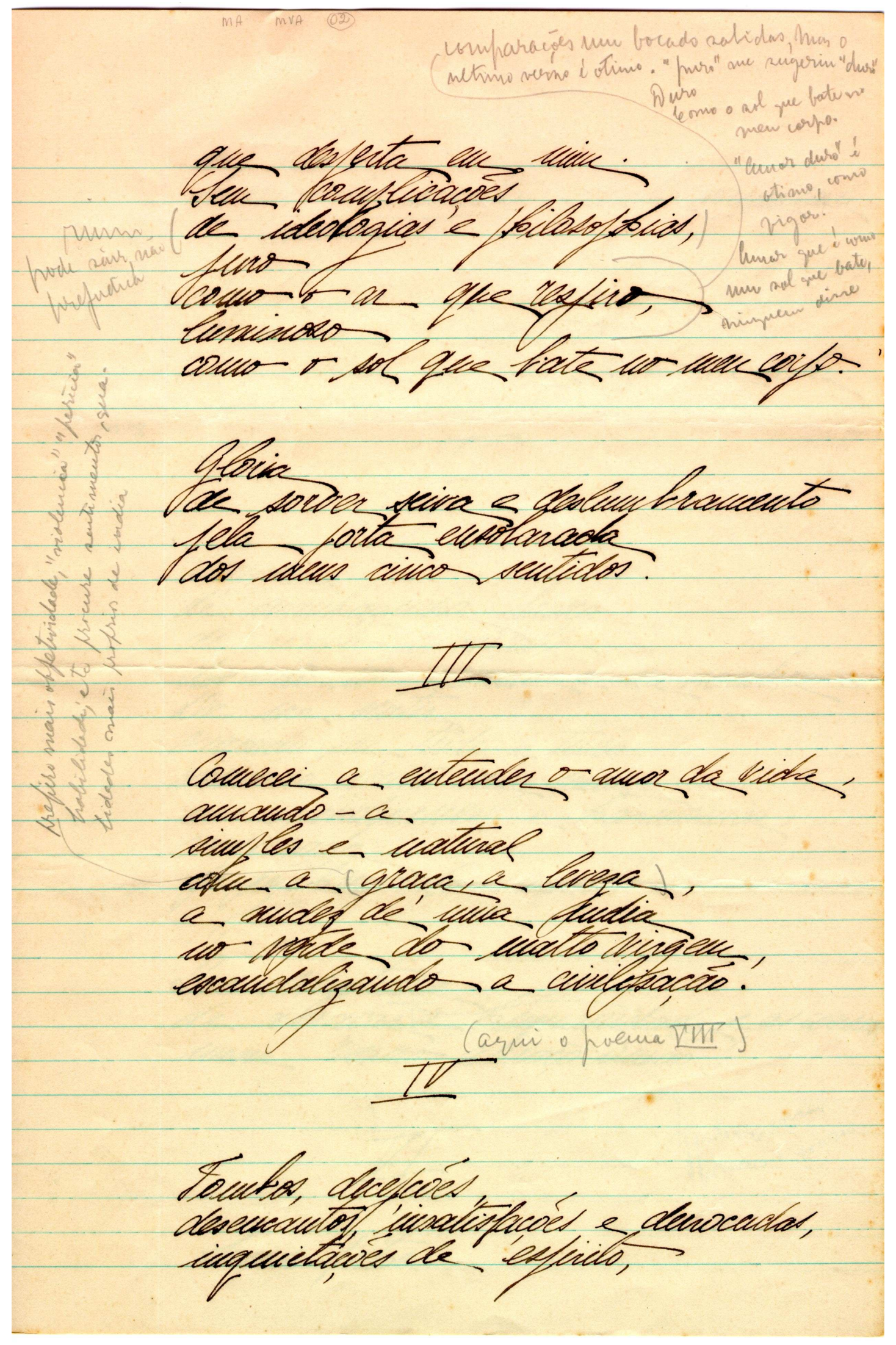




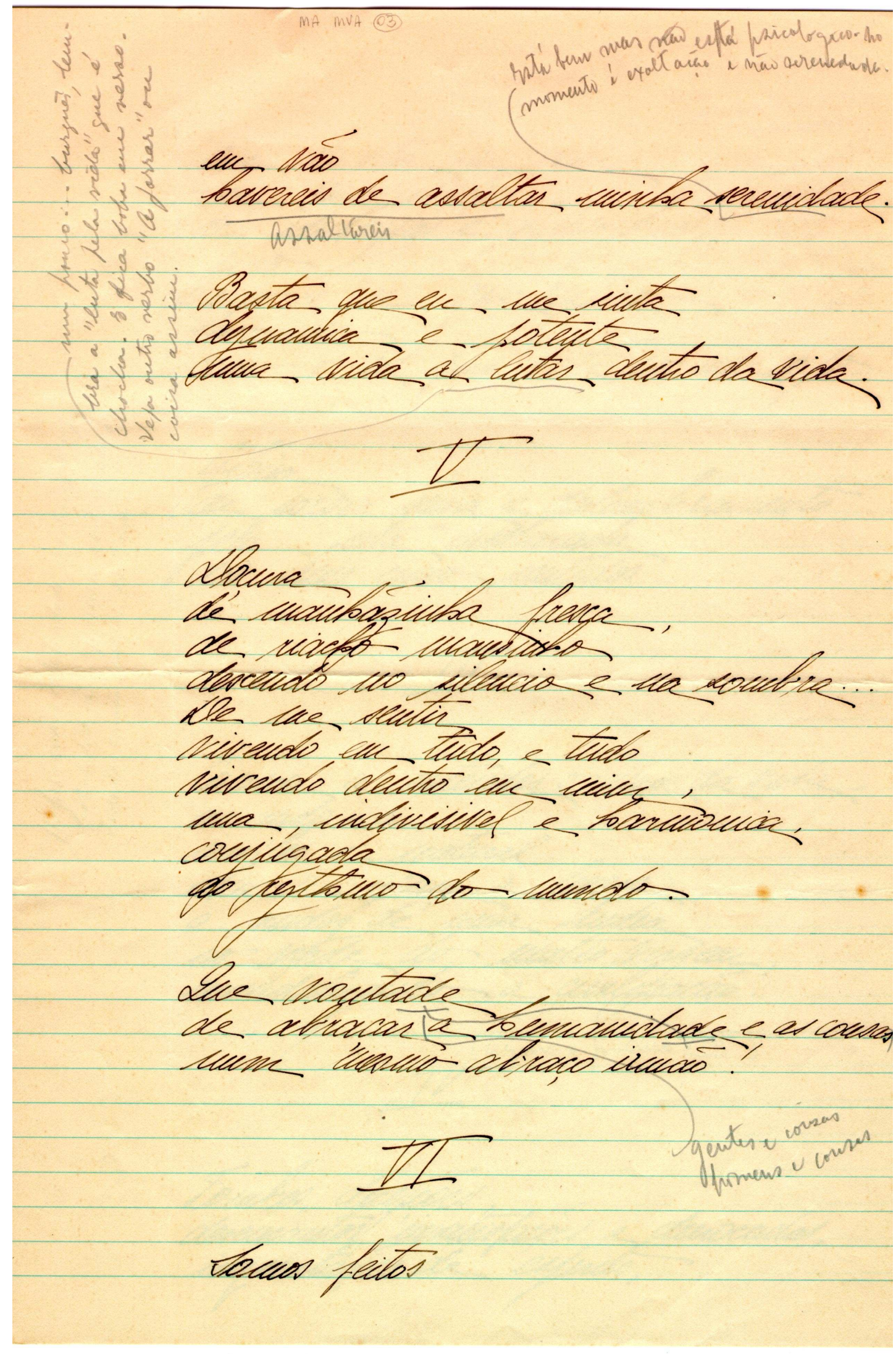


MA - MOE, 31

ALVARENGA, Oneida (Oneida Paolielo Alvarenga 1911-1984)

\section{A Menina Boba; poesia (MAm)}

[Varginha / São Paulo?], 1932-1934

Autógrafo a tinta preta, conjunto de poemas reunido em caderno de capa dura em papel artesanal, estampa floral vermelha; 22,9 × $15,9 \mathrm{~cm}$; timbre no verso da capa: "TYPOGRAPHIA SIQUEIRA"; lombada de percalux marrom; fólios numerados pela pesquisa: (1), (1) (1) (4); miolo: autógrafo a tinta preta e a tinta azul; papel branco, pautado: f. $2-101 ; 102$ folhas; 22,9 x $15,5 \mathrm{~cm}$; f. 1 : furo na borda superior à direita; manchas de tinta; escrita no anverso: f. 2-59, escrita no verso: f. 3, 15, 18, 20, 22, 25, 28, 30, 33, 35, 39, 46, 53, 54, 55; f. 60-102 em branco; f. 2: etiqueta de indicação da localização do ms na biblioteca MA: "C/I/d/19", título e data em autógrafo a tinta preta: "A Menina Boba | 1932 - 1933"; recorte de jornal, colado na parte esquerda inferior da folha, com a resenha sobre a poesia de OA: BORBA, Glicério. "Vida". Estado de Minas, Belo Horizonte, [6 fev. 1935]; 14,6 x 6,7/7,1 cm; sinais de fungo. Nota OA: título do periódico: datiloscrito, fita azul: " 'Estado de Minas' de 6"; data: a tinta preta: "6-II35". Poemas sem título, a maioria numerada pela escritora em algarismos romanos; fólios numerados pela pesquisa: (2)-(1) (1) (3).

Notas MA a lápis preto: f. 28 (verso): sugestão de substituição, f. 31 (anverso): comentário.

Folhas avulsas no final do volume; a f. 1 colada na última folha do caderno: autógrafo a tinta preta; papel branco12 folhas; f. 1: 10,7/10,8 x 19,7 cm, f. 2-7, 9-12: 10,8 x 19,7 $\mathrm{cm}$, f. 8: 10,9 x 19,7 cm; borda esquerda picotada; sinais de fungo; marcas de grampo; f. 1 (anverso), 7 (verso), 8 (anverso): ferrugem de clipe; f. 1 ferrugem de grampo na margem esquerda; f. 12 colada na f. 1 do caderno; escrita no anverso; poesias numeradas pela escritora: I-VII (f. 1-7), I-V (f. 8-12); fólios numerados pela pesquisa: (1) (1) (5)- (1) (1) (6).

Notas MA a lápis preto: f. 2-3: sugestão de substituição, f. 8-9: sugestão de substituição e comentários.

Os poemas, no caderno, estão agrupados em séries, estas com a data da criação; trazem título as séries f. 2: "A Menina Boba | 1932-1933": f. 3-18: poemas "Queimada pelo sol, desvairada", "Amor novo da vida", "Comecei a entender o amor da vida", "Vento que corropia", "Nunca sinto inveja de ninguem que róla no pó", "Ando com os olhos desvairados de céo", "Pensamento de que os meus braços quentes", "Vontade de me diluir, de me fluidificar", "Tombos, decepções,", "Doçura", "Me embasbaco deante de uma flor,", "Transformar esta inutil virgindade", "Olho os meus braços brancos", "Andrajosa, ulcerada, miseravel?", "Voltei cansada", "Carrégo o ultimo raio de sol dentro de mim."; f. 19: "26-VI-1932": f. 20: poema "Fugir de você, pra que?"; f. 21: "11-IX-1932": f. 22-23: poema "Esta seria a cantiga"; f. 24: "Maio de 1933.": f. 25-26: poema "Nem nunca que um dia assim"; f. 27: "7-II-1933.": f. 28: poema "Depois do sol veio a chuva,"; f. 29: "15-VII-1932.": f. 30-31: poema "Você não póde ser na minha vida"; f. 32: "Manhã e Revoluções. | 1-IX-1932.": f. 33: poema "Só eu sinto, decerto,"; f. 34: "Outubro de 1932.": f. 35-39: poemas "Eu queria cahir na tua vida", "Teus 
hombros attráem minha cabeça", "Eu vou partir.", "Tenho medo...", "Ha tantas vozes que me chamam..."; f. 40: "9-XI-1932.": f. 41-44: poemas "Não te posso beijar com a violencia", "Ter que renunciar quando eu apalpo em mim", "Amordaça o grito estridente da tua mocidade", "Deixe que eu beba o teu amor apenas"; f. 45: "10-XI1932.": f. 46-47: poema "Hontem tentaram me amolar não sei porque."; f. 48: "A Menina Exhausta. | (Maio de) 1933-1934.": f. 49-59: poemas "Eu te esperei na hora silenciosa...", "Acho que a minha janela há noite", "Meu corpo se alonga sob teus dedos.", "Havia só", "A distancia tinha falas estranhas...", "Vieste enrolado no perfume dos manacás" (data na margem inferior: "29-IX-1933"), "Eu agora não queria ser eu.", "És como um socego de fim de tarde." (data na margem inferior: "29-IX-1933"), "Gósto das coisas mansas," (data na margem inferior: "29-IX-1933"), "Me debruço na noite." (data na margem inferior: 16-XI-1933), "O vento levanta de leve a cortina.", "Se eu fosse um fróco de paina", "Ha serenidades largas em roda de mim.", "Inquietude impregnante da sombra...".

Os poemas nas folhas avulsas não apresentam título: o incipt de cada um: "Só tu ès o consolo e a quietude.", "No meio da noite minha ternura cairía sobre ti", "Ai! Repouso largo das tardes abertas,", "A sombra está procurando o meu coração.", "Tens a essencia das coisas serenas e fortes nos teus dedos.", "Sei que o vento fresco anda correndo lá por fóra.", "Me livras do mundo e das coisas,", "Segui sozinha e esqueci para trás a minha alma.", "Ha vidas longinquas passando na minha vida.", "As gentes estranhas caminham no escuro,", "O sol clareia as sendas tormentosas.", "Todas as coisas poderiam cessar um instante".

\section{Notas da pesquisa:}

1. Ms na vertente Mário de Andrade mentor.

2. O local foi atestado pela análise da correspondência trocada entre MA e OA. Até a mudança definitiva para São Paulo, no final de 1935, com o objetivo de assumir o cargo de diretora da Discoteca Pública a convite de MA, então diretor do Departamento de Cultura da Municipalidade de São Paulo, OA escrevia tanto na capital paulista como em Varginha, sua terra natal.

3. OA enviou o recorte de jornal a MA acompanhando a carta de 7 de fevereiro de 1935 , onde se lê: "parece que em Minas Gerais estão recebendo de braços abertos a sua discípula: meu irmão Ney encontrou por acaso essa crônica que aqui vai no Estado de Minas de ontem. Lhe mando porque sei que o senhor também fica contente" (Mário de Andrade - Oneyda Alvarenga: cartas. ed. cit., p. 82).

4. Para incentivar a jovem escritora a cultivar uma certa disciplina em seu trabalho, o conselho de MA foi manter um caderno para passar a limpo os poemas, caderno que devia ser a ele enviado com regularidade. Os poemas eram ali transcritos em ordem cronológica da redação, conforme se depreende da correspondência do mestre com a discípula. No entanto, no ms no caderno, a cópia de AO não seguiu a ordem cronológica da criação. Na carta a OA, São Paulo, 2 jan. 1933, MA trata de sua leitura: "Li, reli os seus versos, gostei de alguns, outros me interessaram bem menos, andei tomando umas notas itinerantes, no seu caderno mesmo, e que você aqui lerá." (Mário de Andrade - Oneyda Alvarenga: cartas. ed. cit., p. 38), o que não coincide com as duas notas MA presentes no ms em questão. 
5. A etiqueta colada na segunda folha indica que o caderno de OA entrou para a biblioteca de MA, separada dos ms dos demais escritores, não classificados.

6. A Menina Boba, o único livro de poesia de Oneida Alvarenga saiu em 1938 ( São Paulo, Empresa Gráfica da "Revista dos Tribunais"); reúne os textos "Queimada pelo sol, desvairada", "Amor novo da vida", "Comecei a entender o amor da vida", "Vento que corropia", "Nunca sinto inveja de ninguem que róla no pó", "Ando com os olhos desvairados de céo", "Pensamento de que os meus braços quentes", "Vontade de me diluir, de me fluidificar", "Tombos, decepções,", "Doçura", "Me embasbaco deante de uma flor,", "Transformar esta inutil virgindade", "Olho os meus braços brancos", "Andrajosa, ulcerada, miseravel?", "Voltei cansada", "Carrégo o ultimo raio de sol dentro de mim.", "Depois do sol veio a chuva,", "Você não póde ser na minha vida", "Teus hombros attráem minha cabeça", "Eu vou partir.", "Tenho medo...", "Ha tantas vozes que me chamam...", "Hontem tentaram me amolar não sei porque.", "Eu te esperei na hora silenciosa...", "Acho que a minha janela há noite", "Meu corpo se alonga sob teus dedos.", "Havia só", "A distancia tinha falas estranhas...", "Vieste enrolado no perfume dos manacás", "Eu agora não queria ser eu.", "És como um socego de fim de tarde.", "Gósto das coisas mansas,", "O vento levanta de leve a cortina.", "Se eu fosse um fróco de paina", "Ha serenidades largas em roda de mim.", "Inquietude impregnante da sombra...".

7. Os poemas nas folhas soltas permaneceram inéditos.

8. Em 28 de maio de 1939, MA, crítico do Diário de Notícias do Rio de Janeiro, em sua coluna Vida Literária, focaliza o livro de OA Menina Boba em "As três faces do eu". O artigo, além de analisar o livro, aborda a poesia de Fernando Mendes de Almeida, em Carrussel fantasma e a de Rossini Camargo Guarnieri, em Porto inseguro, obras de publicação recente. (Documento no Arquivo Fernando Mendes de Almeida, série Recortes de periódicos, álbum 2, f.10, IEB-USP). Em carta de 30 maio 1939, OA agradece a MA o artigo: "fiquei completamente derretida com a sua crônica de domingo. Acho que nunca sorri tanto na minha vida, custei a fechar a boca. Gosto igual só experimentei uma vez, e me veio de você mesmo: foi quando os meus primeiros versos, aqueles que mamãe me fez mostrar-lhe, mereceram a sua atenção." (Mário de Andrade - Oneyda Alvarenga: cartas. ed. cit., p. 186).

9. Há dois exemplares de A Menina Boba na biblioteca MA. No primeiro, muits dos comentários valem como notas prévias da parcela sobre AO no artigo "As três faces do eu" (Op. cit.). No segundo exemplar, no qual as folhas dos cadernos não foram abertas pela espátula de MA, a folha de ante-rosto traz a dedicatória: "Mario | com a minha mais per- | feita amizade e minha imensa | gratidão, guarde este livro | que é seu. | Oneyda. | 18-V-1938”.

\section{Estudo genético:}

1. Os poemas do caderno: "Queimada pelo sol, desvairada", "Amor novo da vida", "Comecei a entender o amor da vida,", "Vento que corropia", "Tombos, decepções", "Doçura", "Fugir de você, pra que?", "Andrajosa, ulcerada, miseravel?", "Havia só", "Voltei cansada" mostram-se em versão B. A versão A dos poemas fora encaminhada para MA, em jun. 1932 (V. MA-MOE, 30).

2. Os demais poemas do caderno e das folhas avulsas apresentam-se em versão A.

3. "Nunca sinto inveja de ninguem que róla no pó", "Ando com os olhos desvairados de céo", "Pensamento de que os meus braços quentes", "Vontade de me diluir, de me 
fluidificar", "Me embasbaco deante de uma flor,", "Transformar esta inutil virgindade", "Olho os meus braços brancos", "Voltei cansada", "Carrégo o ultimo raio de sol dentro de mim.", "Esta seria a cantiga", "Nem nunca que um dia assim", "Depois do sol veio a chuva,", "Você não póde ser na minha vida", "Só eu sinto, decerto,", "Eu queria cahir na tua vida", "Teus hombros attráem minha cabeça", "Eu vou partir.", "Tenho medo...", "Ha tantas vozes que me chamam...", "Não te posso beijar com a violencia", "Ter que renunciar quando eu apalpo em mim", "Amordaça o grito estridente da tua mocidade", "Deixe que eu beba o teu amor apenas", "Hontem tentaram me amolar não sei porque.", "Eu te esperei na hora silenciosa...", "Acho que a minha janela há noite", "Meu corpo se alonga sob teus dedos.", "Havia só", "A distancia tinha falas estranhas...", "O vento levanta de leve a cortina.", "Se eu fosse um fróco de paina", "Ha serenidades largas em roda de mim.", "Inquietude impregnante da sombra..." mostra uma etapa na escritura: autógrafo a tinta preta.

4. "Gósto das coisas mansas,", mostra 1 etapa na escritura: autógrafo a tinta azul.

5. "Vieste enrolado no perfume dos manacás", "És como um socego de fim de tarde.", "Gósto das coisas mansas," possui 2 etapas na escritura: a-a

a: autógrafo a tinta azul;

$\mathrm{a}_{1}$ : autógrafo a tinta preta.

6. "Eu agora não queria ser eu.", exibe 3 etapas na escritura: $a_{-} a_{1}-a_{2}$ :

a: autógrafo a tinta preta;

$\mathrm{a}_{1}$ : autógrafo a tinta azul;

$\mathrm{a}_{2}$ : autógrafo a tinta preta.

7. Os poemas em versão B mostram 1 etapa na escritura: autógrafo a tinta preta.

8. Os poemas das folhas soltas mostram 1 etapa na escritura.

9. Versão B de "Amor novo da vida", "Comecei a entender o amor da vida,", "Vento que corropia", "Tombos, decepções", "Doçura", "Andrajosa, ulcerada, miseravel?", "Havia só", "Voltei cansada", com variantes em relação à versão A. Foram acatadas em B, as sugestões das Notas MA da versão A.

10. As versões A e B no caderno foram confrontadas com a versão C: A Menina Boba (ed. cit.).

11. A versão $C$ apresenta variantes em relação à versão $A$ e aos seguintes poemas da versão B: "Amor novo da vida que desperta em mim", "Tombos, decepções", "Doçura", "Andrajosa, ulcerada, miseravel?".

12. O confronto das versões ao lado da análise da correspondência, evidencia uma espécie de co-autoria entre MA e AO. 
II

Cuma navo da cida

- que desferta cur Uism.

- souvo or ar que veffic, duno- sol que hate wo. neu coyp.
cour o sol que

MA MVA (05)

Glovia

porrn seiva e destumstranumb fela forta ensolonades

68 
III

Comesei a cuteuth o caver da bida sumandes - a untural,

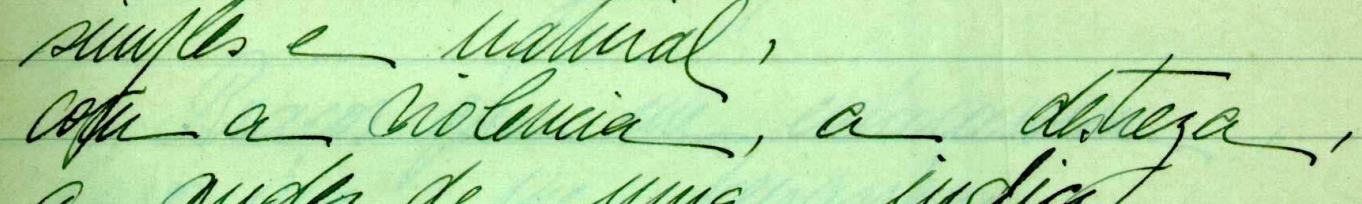
a audes de luma india seadelatygando a cintligacais.

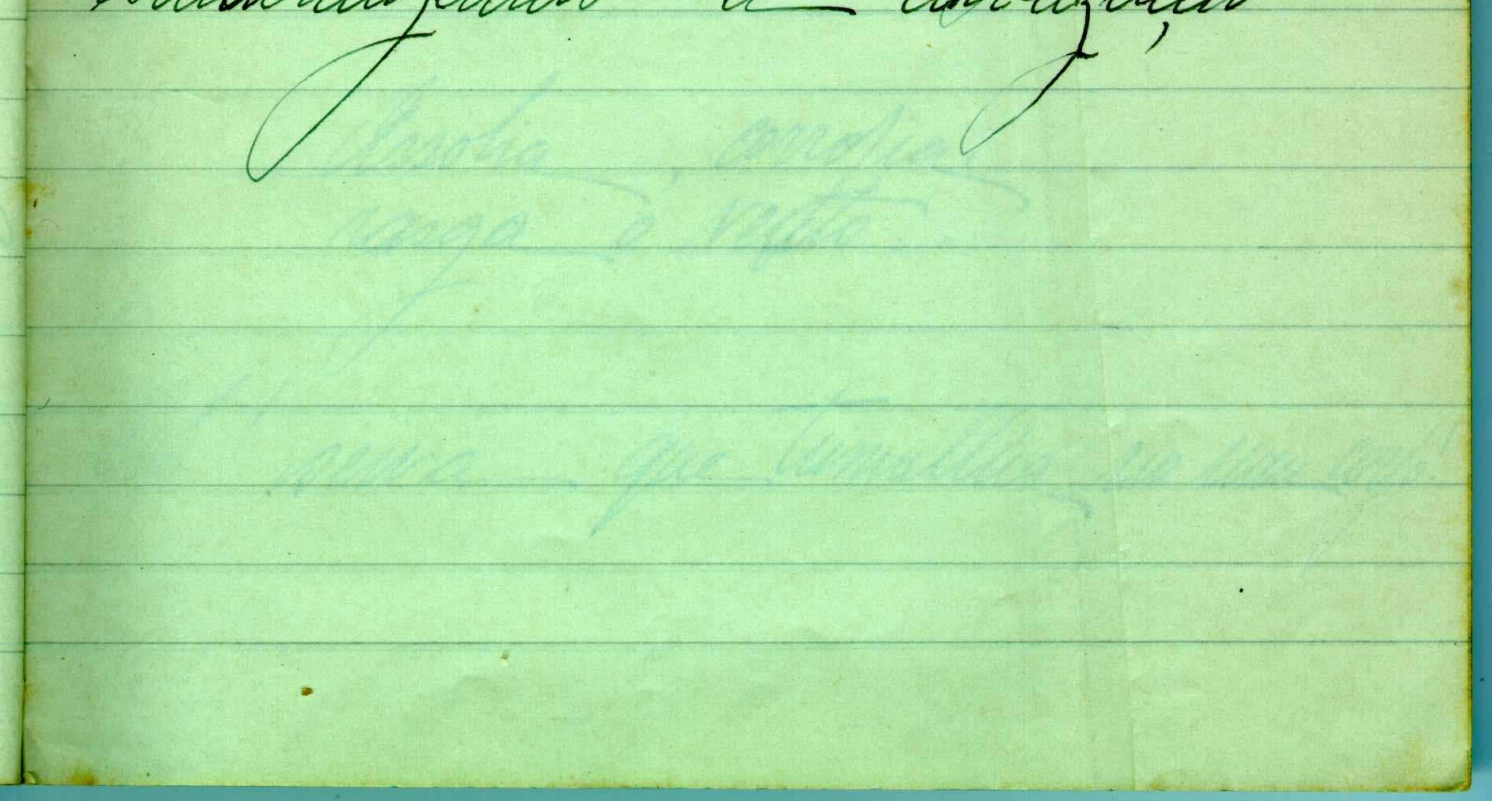

69 


\section{MA - MOE, 32}

ALVARENGA, Oneida (Oneida Paolielo Alvarenga 1911-1984)

32. "Oh! noite pasmada como um olho cego!"; "Desnorteamento sem fim da escuridão..."; "As rodas de um trem esmagaram um minuto o silêncio."; "Me arrastam no espaço sem luzes!"; "Minha alma se feriu nas pontas agudissimas da sombra.": poesia (MAm) [Varginha / São Paulo, ant. 1938?]

Datiloscrito, cópia carbono azul; papel branco, filigrana; 5 folhas; 13,3/ 13,4 x 20,8 $\mathrm{cm}$, com variações em mm; borda inferior irregular; vinco; f. 3 , 5: sinais de fungo; escrita no anverso; poemas numerados pela pesquisa: "I"-"V"; rasuras a máquina e a tinta preta; fólios numerados pela pesquisa: (1)-(5).

\section{Notas da pesquisa:}

1. Ms na vertente Mário de Andrade mentor.

2. Data atestada pelo ano de edição do livro de Oneida Alvarenga A Menina Boba. (São Paulo, Empresa Gráfica da "Revista dos Tribunais", 1938), no qual os poemas estão publicados, o que revela envio anterior a 1938.

3. Local atestado com base na correspondência trocada entre MA e OA.

\section{Estudo genético:}

1. O ms apresenta-se em uma única versão, A.

"Oh! noite pasmada como um olho cego!" mostra 1 etapa na escritura.

2. "Desnorteamento sem fim da escuridão...", "As rodas de um trem esmagaram um minuto o silêncio.", "Me arrastam no espaço sem luzes!" mostram duas etapa na escritura: $a-a_{1}$ :

a: datiloscrito completo;

$\mathrm{a}_{1}$ : rasuras a máquina.

3. "Minha alma se feriu nas pontas agudissimas da sombra." mostra 2 etapas na escritura: $\mathrm{a}-\mathrm{a}_{1}$ :

a: datiloscrito completo;

$\mathrm{a}_{1}$ : rasura a tinta preta.

4. Versão A confrontada com a versão B, em A Menina Boba (ed. cit.).

5. Somente a versão A de "Ôh! Noite pasmada como um olho cégo!" e de "As rodas de um trem esmagaram um minuto o silêncio." apresentam variantes em relação à versão B.

\section{MA - MOE, 33}

ALVARENGA, Oneida (Oneida Paolielo Alvarenga 1911-1984)

33. "Todas as bocas da treva gritam nêste instante"; "Volte a hora do amor, a hora humilde,"; "Me arrasto pela noite sem repouso,"; poesia (MAm)

[São Paulo], 24 abr.-26 jun. 1939

Datiloscrito, cópia carbono preto; papel branco; 3 folhas; f. 1-2: 22 x 14,5 cm, f. 3: 22 x 14,0 cm; f. 1-2: borda esquerda irregular; f. 3: bordas direita e esquerda irregulares; 
vincos; sinais de fungo; f. 2: marca de ferrugem; escrita no anverso; datas: f. 1-2: "24IV-1939”, f. 3: "26-VI-1939”; fólios numerados pela pesquisa: (1)-(3). Notas MA.

"Todas as bocas da treva gritam nêste instante":

Nota MA a lápis preto: "Oneida".

"Volte a hora do amor, a hora humilde,":

Notas MA a lápis preto: "Oneida" e grifo no último verso.

"Me arrasto pela noite sem repouso,":

Nota MA a lápis preto: "Oneida".

Notas da pesquisa:

1. Ms na vertente Mário de Andrade mentor.

2. Local atestado pela análise da correspondência trocada entre MA e OA. Até a mudança definitiva para São Paulo, no final de 1935, com o objetivo de assumir o cargo de diretora da Discoteca Pública a convite de MA, então diretor do Departamento de Cultura da Municipalidade de São Paulo, OA passou a se dedicar ao estudo de música popular e ao folclore. Continuou a escrever poemas.

3. Na carta a OA, datada: Rio de Janeiro, 25 de julho de 1939, MA analisou os poemas no ms. Na carta de OA, de São Paulo, 6 de setembro de 1939 está a resposta. (ANDRADE, Mário de. Op. cit., p. 191-196).

Estudo genético:

1. No arquivo MA os textos apresentam-se em uma única versão, A, no datiloscrito, cópia carbono que que mostra 1 etapa na escritura.

\section{MA - MOE, 34}

ANDRADE, Carlos Augusto de (1855-1917)

34. [A mão da caridade]; teatro (MAc)

[São Paulo], s/ data

Autógrafo a tinta preta; caderno sem capa; papel branco, f. 2 a 99 pautadas; 100 folhas; 22,0 x 16,9 cm; f. 91 solta; f. $1-9$ presas ao caderno apenas por uma das costuras; f. 1 : vinco no canto inferior direito e canto superior direito rasgado; f. 1, 27, 91: rasgamento na borda direita; f. 22: vinco vertical, f. 29, 31, 69: vinco no canto superior direito; sinais de fungo; f. 22, 47, 94: escrita no anverso, f. 4, 8-20, 23-46, 49-93: escrita no anverso e no verso; f. 4: etiqueta com a localização na biblioteca MA: "E/I/d/63"; rasuras a tinta preta e a lápis preto; fólios numerados pela pesquisa: (1)-(1) (0)(0). Ms acondicionado em envelope de cartolina branca feito a mão; 23,0 x 18,5 cm.

\section{Notas da pesquisa:}

1. Ms na vertente Mário de Andrade colecionador.

2. Carlos Augusto de Andrade é pai de MA. O texto antecede 15 de fevereiro de 1917, quando faleceu o autor. 
3. O gosto de MA por colecionar livros e manuscritos foi herdado do pai, conforme se pode depreender de cartas de Pio Lourenço Correa dirigidas a MA.

Estudo genético:

1. O ms apresenta-se em uma única versão, A, que mostra 3 etapas na escritura: $a-a_{1}-a_{2}$ : a: autógrafo completo;

$\mathrm{a}_{1}$ : rasuras a tinta preta;

$\mathrm{a}_{2}$ : rasuras a lápis preto.

MA - MOE, 35

ANDRADE, Carlos Augusto de (1855-1917)

35. "É certo? A teus pés prostrado"; poesia (MAc)

[São Paulo], s/ data

Autógrafo a tinta preta; papel branco, pautado, filigrana; 1 folha; 16,3/ 16,4 x 21,3/

$21,9 \mathrm{~cm}$; rasgamentos na borda esquerda; vinco; sinais de fungos; escrita no anverso; desenho a lápis preto no verso; fólio numerado pela pesquisa: (1).

Notas da pesquisa:

1. Ms na vertente Mário de Andrade colecionador. Trata-se, na verdade do colecionador vinculado tanto à produção literária como à memória familiar, pois Carlos Augusto de Andrade, pai de Mário, escreveu poesia e peças de teatro.

2. V. MA-MOE, 34, notas 2-3.

Estudo genético:

1. No arquivo MA o ms apresenta-se em uma única versão, A, o autógrafo que mostra 1 etapa na escritura.

MA - MOE, 36

ANDRADE, Carlos Drummond de (1902-1987)

36. Não foi mais do que isso; Religião; Comedia; poesia (MAm)

[Belo Horizonte, 24 nov. 1924]

Datiloscrito, cópia carbono roxo; título em datiloscrito original, fita vermelha; papel branco; 4 folhas; 22,2 x 16/16,2 cm, com variação em mm; vinco; sinais de fungo; f. 3-4: ferrugem de clipe; manchas de carbono; escrita no anverso; f. 4: numerada pelo escritor: "-2-"; visto do escritor a tinta preta: "CDA"; rasuras a tinta preta; fólios numerados pela pesquisa: (1)-(4). Nota CDA a tinta preta: f. 4: comentário.

Notas da pesquisa:

1. Ms na vertente Mário de Andrade mentor.

2. Data e local atestados com base na correspondência trocada entre MA a CDA. Em 22 de novembro de 1924, CDA enviou poemas a MA, sem mencionar quantidade e títulos. 
A resposta de MA refere-se à devolução dos ms e, ao analisar os poemas, cita Religião. Em 30 de dezembro de 1924 CDA informa o amigo: "Devolvo-lhe quase todos os versos: cortei apenas os que me pareciam mais ordinários. Seguem ainda uns que você não conhece, embora não sejam os últimos" (FROTA, Lilia Coelho org. Carlos \& Mário: Correspondência completa entre Carlos Drummond de Andrade e Mário de Andrade. Rio de Janeiro, Bem-te-vi, 2003) O conjunto de ms Não foi mais do que isso, Religião e Comedia, possivelmente, faziam parte desse conjunto de ms devolvido a MA.

\section{Estudo genético:}

1. No arquivo MA os ms apresentam-se em uma única versão, A, o datiloscrito na cópia que mostra, em Religião, 1 etapa na escritura e, em Não foi mais do que isso e Comedia, 2 etapas na escritura: a- $\mathrm{a}_{1}$ :

$\mathrm{a}_{1}$ : datiloscrito completo;

$\mathrm{a}_{1}$ : rasuras a tinta preta.

\section{MA - MOE, 37}

ANDRADE, Carlos Drummond de (1902-1987)

\section{Antonío Conselheiro; poesia (MA)}

[Belo Horizonte], 1925

Datiloscrito original, fita vermelha; papel verde, pautado; 5 folhas; $27,1 \times 20,7 / 20,9$ cm; vincos; f. 2: rasgamento na margem esquerda, f. 3, 5: rasgamento na margem inferior; sinais de fungo; marca de clipe; folhas numeradas pelo escritor: "II"-"V"; escrita no anverso; rasuras: f. 1: a máquina e a tinta azul, f. 2: a máquina e a tinta azul, f. 3: a tinta azul e preta e a lápis preto, f. 4 a máquina e a tinta azul, f. 5: a tinta preta; f. 5: data e assinatura a tinta azul: "1925 | Carlos Drummond"; fólios numerados pela pesquisa: (1)-(5).

Nota MA a lápis vermelho: f. 2: traço vertical na margem esquerda do verso 29: "Parece que havia um raio... Seccou!".

\section{Notas da pesquisa:}

1. Ms na vertente Mário de Andrade mentor.

2. CDA e MA se encontraram pela primeira vez em abril de 1924, por ocasião da "Viagem de descoberta do Brasil", quando os modernistas de São Paulo Mário de Andrade, Oswald de Andrade e Tarsila do Amaral, com sua mecenas Olívia Guedes Penteado e o genro dela Gofredo da Silva Teles percorreram as cidades históricas de Minas Gerais acompanhando o poeta da vanguarda francesa Blaise Cendrars. Um grupo de jovens escritores mineiros formado por Martins de Almeida, Pedro Nava, Emílio Moura e Carlos Drummond de Andrade foi até o Grande Hotel de Belo Horizonte para ali conhecer Mário. Naquele momento, Drummond, então um jovem poeta, tomou Mário por mentor. Em poucos anos a situação seria superada, CDA se tornou poeta à altura de um diálogo com o autor de Paulicéia desvairada.

3. CDA endereçou a MA o ms de Antonio Conselheiro junto com carta de março de 1925, onde está: "Com a leitura fresca de Os sertões, era meu desejo fazer um poema - ora, 
imagine! - sobre o místico sertanejo Antônio Conselheiro. Comecei mesmo esse trabalho, que a preguiça e o desânimo vieram interromper, provavelmente de vez. Já perdi o surto lírico. Aliás, a obra era dura; confesso que não tenho outros materiais senão o livro de Euclides. E depois, Euclides dramatizou tanto o caso, que nada resta a fazer. Estou convencido que Os sertões é uma grande epopéia. Meu trabalho, pois, seria pretensioso e vão. Em todo caso, como gosto de seu julgamento, mando-lhe o que já fiz. Não sei que demônio interior me segreda haver nesses versos influência de você. É possível e, se confesso a possibilidade dessa influência, não é para the prestar vassalagem intelectual, que você repeliria e eu não saberia prestar. Se houve, foi inconsciente, eis aí. [...] Seja franco ainda uma vez comigo, e diga-me se devo ou não rasgar esses versos." (FROTA, Lilia Coelho org. Carlos \& Mário: Correspondência completa entre Carlos Drummond de Andrade e Mário de Andrade. Ed. cit., p. 109)

4. A resposta de MA chegou a CDA na missiva de São Paulo, [ant. 20 maio 1925], que analisa Antonio Conselheiro e comenta o poema Música, provavelmente recebido na mesma ocasião. O poema, que não encontrado no Arquivo do escritor, mereceu as observações: "'Música é uma gostosura. Você carece mudar aquele "nos passos que era preciso correr' clássico demais. E bote 'meus cuidados avoaram que nem borboletas'. Talvez 'cuidados' seja palavra que você possa mudar por outra mens lugar-comum poético. Mas pode ficar assim." (ANDRADE, Carlos Drummond de e ANDRADE, Mário de. Op. cit., p. 114-115). Há, na série Manuscritos de outros escritores, uma versão posterior de Música, com Notas MA. (V. MA - MOE, 39).

5. A resposta de CDA a MA, em 20 de maio de 1925, volta ao assunto do poema: "Discordo de você quando acha o assunto do meu 'Antonio Conselheiro' 'muito tema demais' [...]. Pus de lado o 'Conselheiro', mas continuo a cismar que ele podia dar alguma coisa". (FROTA, Lilia Coelho org. Carlos \& Mário: Correspondência completa entre Carlos Drummond de Andrade e Mário de Andrade. Ed. cit., p. 121).

6. Antonio Conselheiro permaneceu inédito em livro.

7. Antes de Antonio Conselheiro, CDA havia enviado a MA um conjunto de poemas cujos títulos não cita, junto com a carta de 22 de novembro de 1924. MA analisa os poemas Política, Construção, Religião, Nota social, Sentimental, Orozimbo, Nomeio do caminho talvez devolvidos a CDA em resposta não datada (V. MA-MOE, 36, nota 2).

Estudo genético:

1. No arquivo MA o ms apresenta-se em uma única versão, A, passada a limpo no datiloscrito que mostra 4 etapas na escritura: $a-a_{1}-a_{2}-a_{3}$ :

a: datiloscrito completo;

$\mathrm{a}_{1}, \mathrm{a}_{2}, \mathrm{a}_{3}$ : rasuras a tinta preta, a tinta azul e a lápis, sem possibilidade de se identificar a ordem dessas etapas.

MA - MOE, 38

ANDRADE, Carlos Drummond de (1902-1987)

38. Jardim da praça da Liberdade; poesia (MAd) [Belo Horizonte, ant. maio 1926 ?] 
Autógrafo a tinta azul; papel branco, filigrana: "Linen Bank"; papel dobrado ao meio formando 2 folhas; 20,6 x 13,9 cm; vincos; rasgamento no vinco; sinais de fungo; escrita no anverso; rasuras a tinta azul; f. 2: assinatura: "Carlos Drummond"; fólios numerados pela pesquisa: (1)-(2).

Notas da pesquisa:

1. Ms na vertente Mário de Andradeno diálogo interpares.

2. Data e local atestados com base no caderno de poesias Minha terra tem Palmeiras que CDA enviou a MA, passado a limpo em maio de 1926, que guarda versão de Jardim da praça da Liberdade posterior à do ms acima classificado (V. MA-MOE, 39).

3. Publicado em Alguma poesia (Belo Horizonte, Edições Pindorama, 1930).

4. Sobre Alguma poesia, MA escreveu na Revista Nova, n 1 , São Paulo, em 1931, o artigo "A poesia em 1930," no qual focaliza os livros recém-publicados Libertinagem, de Manuel Bandeira, Pássaro Cego, de Augusto Frederico Scmidt e Poemas, de Murilo Mendes. "A poesia em 1930" saiu na coletânea de ensaios de MA, Aspectos da literatura brasileira (Rio de Janeiro, Americ - Edit., 1943).

\section{Estudo genético:}

1. No arquivo MA o ms apresenta-se em versão A, passada a limpo no autógrafo que mostra 2 etapas na escritura: $a-a_{1}$ :

a: autógrafo completo;

$\mathrm{a}_{1}$ : rasuras a tinta azul.

2. O poema Jardim da praça da Liberdade apresenta uma versão posterior, B, no arquivo MA (V. MA-MOE, 39).

3. A versão A confrontada com as versões B e C, esta no livro Alguma poesia (ed. cit.) mostra variantes.

\section{MA - MOE, 39}

ANDRADE, Carlos Drummond de (1902-1987)

39. Minha terra tem Palmeiras; poesia (MAm)

Itabira, maio 1926

Caderno tipo brochura "caderflex"; capa verde escuro; perda de celulose na lombada; 22,6 x 15,4 cm; mancha de tinta preta no verso da capa; vinco transversal na quartacapa; cantos e bordas desgastados; miolo: textos em autógrafo a tinta preta; papel branco, pautado: f. 2-50; 51 folhas; 22,6 x 15,4 cm; sinais de fungo; f. 9-10: soltas; entre f. 16 - 17: sinal de folha arrancada; manchas de tinta; f. 25: rasgamento na borda superior à direita; f. 49: rasgamento na borda inferior à esquerda; f. 35: furo na margem esquerda; f. 35-36: páginas numeradas pelo escritor: 1, 3, 2: corrigindo lapso na sequiência da redação do poema; escrita no anverso e no verso; f. 2: dedicatória, local e data: "Ao querido Mario | esta lembrança do | Carlos | Itabira, 926"; f. 24: título de série de poemas, dedicatória, local e data: "Minha Terra tem palmeiras | a Mario de Andrade | oferece | Carlos Drummond | Itabira, maio 926"; f. 50: local e data: "Itabira | 31 maio | 1926"; poemas com dedicatória: Música: verso da f. 36: "A Pedro Nava", Sabará: f. 43: "A Anibal Machado"; rasuras a tinta preta; fólios numerados pela 
pesquisa: (1)-(5) (3). Notas CDA a tinta preta: indicação dos poemas publicados, f. 43: sobre o homenageado na dedicatória: "(1) A pessôa mais inteligente que nasceu $\mid \mathrm{em}$ Sabará"; f. 7: sinal de palavra apagada: "Publicado". Ms acondicionado em espécie de envelope, feito com papel branco, tipo cartolina; $18 \times 24,5 \mathrm{~cm}$.

Notas MA a lápis preto: comentários e sugestões de substituições; a lápis vermelho: sinal de " $\mathrm{x}$ " destacando poemas.

O ms apresenta os títulos:

Convite, A beleza da vida na alegria da manhã, Sensual, Quasi-noturno em voz baixa, Ainda um noturno, Ninguem sabe..., Biblioteca, A mulher do elevador, Primavera nas folhinhas e nos jardins, Cromo-litografia, Vê como a agua sussurra, Na tarde cheia de doçura, Como si eu fôsse um poeta resignado, Boneca de pano, Uma lámpada brilha, Matinal, Doçura da hora, Gravado numa parede, Longe do asfalto, O momento feliz, A noie com uma lua que não é séria, Canção do grego desencantado, Oferenda, Sentimental, Hai-Kais urbanos, Espelho túnica e agua, Historia de duas mãos, Sertão melancólico, Destino só. Minha terra tem palmeiras: Lanterna mágica: Belo Horizonte, S. João del Rei, Caeté, Itabira, Ouro Preto, Nova Friburgo, Rio de Janeiro, S. Salvador, Sisma das secretarias, Nota social, Política, Construção, Capital do Estado, Raizes e caramujos, Daguerreotipo, Paizagem burgueza, Cromo, No meio do caminho, Orozimbo, Bucólica no caminho do Pontal, Música, Coração numeroso, Igreja, Tennis, Cantiga de viuvo, Dentista, Eu protesto, Sabará, Explicação, Infancia, Familia, Cidadesinha qualquer, Jardim da praça da Liberdade, Confissão, Poesia do poeta, Epigrama pra Emílio Moura.

\section{Notas da pesquisa:}

1. Ms na vertente Mário de Andrade mentor.

2. O ms foi solicitado por MA a CDA na época em que este, recém-casado, recémformado em Farmácia e desempregado, voltara a morar em Itabira. Diante da hipótese de CDA abandonar a poesia, MA escreve, de São Paulo, em 8 de maio de 1926: "Você falou que eu não me espantasse se um dia você rasgasse o seu caderno de versos. Isso você não tem o direito de fazer e seria covardia. Você pode ficar pratiquíssimo na vida se quiser porém não tem o direito de rasgar o que já não é mais só seu, que mostrou pros amigos e eles gostaram. Antes de mais nada eu estava mesmo com um pedido a fazer pra você e agora você tem tempo e pode cumpri-lo. Eu quero uma cópia de todos os seus versos pra mim. Quero e exijo, é claro. Você vai principiar a copiá-los e vai me mandar isso o mais depressa possível. Pode ter certeza que serei da máxima correção, não publicarei nada sem licença de você, mostrarei só pros que puderem compreender você e na verdade serão só meus. Em compensação hei de mandar pra você as minhas últimas coisas que vão fazer você ficar tiririca comigo" (FROTA, Lilia Coelho org. Carlos \& Mário: Correspondência completa entre Carlos Drummond de Andrade e Mário de Andrade. Ed. cit., p. 215).

3. O diálogo sobre os poemas no ms prossegue ao longo de cartas trocadas entre MA e CDA: em 8 de junho de 1926, MA comunica o recebimento do caderno Minha terra tem Palmeiras e a necessidade sua de comentar versos vindos em carta; em $1^{\circ}$ de agosto de 1926, MA analisa praticamente um a todos poemas do caderno; em 20 de agosto de 1926, CDA acusa a chegada dos comentários de MA; em 31 de agosto de 1926, CDA analisa os comentários de MA (FROTA, Lilia Coelho org. Carlos \& Mário: 
Correspondência completa entre Carlos Drummond de Andrade e Mário de Andrade. Ed. cit.).

4. A carta de 8 de maio de 1926 marca bem as relações de MA mentor de CDA: Mário pede que o poeta mineiro continue a lhe remeter textos; logo abrirá com ele o diálogo interpares que mantinha com Manuel Bandeira.

5. Sentimental, lanterna mágica, Nota social, Política, Construção, No meio do caminho, Música, Coração numeroso, Igreja, Cantiga de viúvo, Sabará, Explicação, Infância, Família, Cidadezinha qualquer, Jardim da Praça da Liberdade e Epigrama pra Emílio Moura foram publicados em Alguma poesia (ed. cit.). Os demais poemas permaneceram inéditos.

6. CDA já havia encaminhado para MA os ms de Política, Construção, Nota social, Sentimental, Orozimbo, Nomeio do caminho, Música, ausentes do arquivo MA.

7. MA escreveu o artigo "A poesia em 1930" sobre o livro de CDA Alguma poesia (V. MA-MOE, 38, nota 4).

Estudo genético:

1. No arquivo MA o poema Jardim da praça da Liberdade apresenta-se nesta versão B, pois uma versão anterior foi enviada a MA (V. MA-MOE, 38). A versão A de Jardim da praça da Liberdade mostra 2 etapas na escritura: a-a $a_{1}$ :

a: autógrafo completo;

$\mathrm{a}_{1}$ : rasura a tinta preta.

2. Os demais poemas apresentam-se em uma única versão, A, que mostra em Convite, Sensual, Biblioteca, A mulher do elevador, Primavera nas folhinhas e nos jardins, Na tarde cheia de doçura, Como si eu fôsse um poeta resignado, Gravado numa parede, Oferenda, Hai-kais urbanos, Espelho técnica e água, sertão melancólico, Destino só, Nota social, Política, Construção, Raizes e caramujos, Cromo, Orozimbo, Coração numeroso, Eu protesto, Explicação, Infancia, Familia, Confissão, Poesia do poeta, Epigrama pra Emilio Moura 2 etapas na escritura: a-a $a_{1}$, e no restante dos poemas 1 etapa na escritura:

a: autógrafo completo;

$\mathrm{a}_{1}$ : rasuras a tinta preta.

3. A versão B de Jardim da praça da Liberdade confrontada com a versão A no ms e com a versão C no livro Alguma poesia (ed. cit.). Há poucas variantes entre elas.

4. Versão A dos poemas no ms confrontada com a versão B em Alguma poesia (ed. cit.), apresentando poucas variantes.

\section{MA - MOE, 40}

ANDRADE, Carlos Drummond de (1902-1987)

40. Elegia do rei de Sião: poesia (MAe)

[Belo Horizonte, post. 07 nov. 1926]

Autógrafo a tinta preta; papel verde, pautado; 1 folha; 27,3 x 21,1 cm; vincos; pequenos rasgamentos nas bordas; sinais de fungo; ferrugem de clipe; escrita no verso; rasuras a tinta preta; assinatura a tinta preta: "C."; fólio numerado pela pesquisa: (1).

Nota MA a lápis preto no verso: "Drummond". 


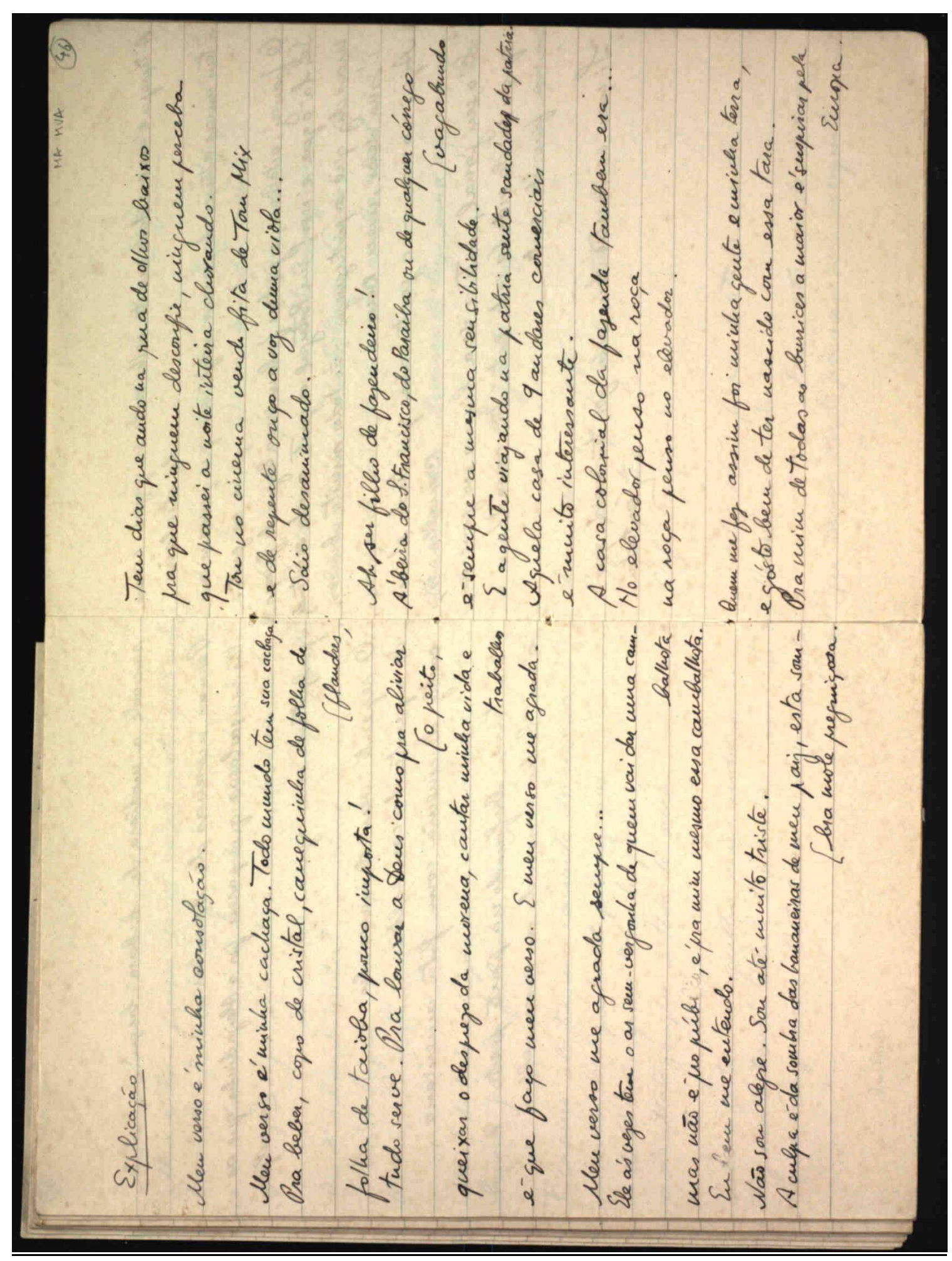


A Enopa e'una cidade muito velka onde so'fajen caso do diculeivo

e tem unas atrijes de pernas seljetivas que passam a perua ua gente.

6 francy, oitaliano, ojuden falam mua lingua de farraps. Seilaroque e' isso! Eue Portugal a gente airida se entende, uas dij que on portuguejes sāo todos nuito burros. I'sinadeles, wer beus.

Agui ao menos a gente rabe que tùdo e'una caualla so', lis sen jornal, wete a sua lingua no governo, queixa da vida (a vida está tar care!) ino fin da cest.

Ji men verso vad den certo for ter ouvido que Feutorton. 
Notas da pesquisa:

1. Ms na vertente Mário de Andrade no diálogo interpares.

1. Data atestada com base na carta de CDA a MA, de Belo Horizonte em 7 de novembro de 1926, na qual o remetente menciona a elaboração de poema sobre o rei do Sião.

2. Publicado em Alguma Poesia (ed. cit.).

Estudo genético:

1. No arquivo MA o ms apresenta-se em uma única versão, A, que mostra 2 etapas na escritura: $a-a_{1}$ :

a: autógrafo completo;

$a_{1}$ : rasuras a tinta preta.

2. A versão A confrontada com a versão B em Alguma Poesia (ed. cit.) mostra poucas variantes.

\section{MA - MOE, 41}

ANDRADE, Carlos Drummond de (1902-1987)

41. O medo; Visão 944; Nos áureos tempos; Assalto; Nova canção do exílio; Equivoco; Edificio São Borja; Idade madura; Cidade prevista; Indicações; poesia (MAd)

[Rio de Janeiro, ant. 1945]

Datiloscrito, cópia carbono preto; papel cor-de-rosa; 18 folhas; 29,5 x 21,9, com variações em mm na altura; vincos; sinais de fungo; furo de grampeador; f. 1, 9: furo; f. 1: ferrugem de grampo; f. 2-9, 11, 13-14: manchas de carbono; f. 3-5: rasgamentos nas bordas; f. 8: rasgamentos na borda esquerda; f. 6: mancha de tinta preta; escrita no anverso; f. 1: dedicatória: "A Antônio Cândido" e citação: "Porque há para tôdos nós um problema | sério... Este problema é o do medo." An | tonio Cândido ('Plataforma de uma gera | ção').”; f. 9: dedicatória: “A Josué Montello"; f. 2-3 numeradas pelo escritor: "2"-“3"; f. 12 numerada a lápis vermelho: "2"; f. 3: rasura a tinta preta; (1(1) (8).

Notas da pesquisa:

1. Ms na vertente Mário de Andrade no diálogo interpares.

2. Data atestada com base no ano de publicação de Rosa do povo e o no da morte de MA.

3. Poemas publicados em Rosa do povo (Rio de Janeiro, Jose Olympio, 1945); circulavam em cópias carbono ou mimeografadas durante os últimos anos da ditadura do Estado Novo.

\section{Estudo genético}

1. No arquivo MA o ms apresenta-se em uma única versão, A, o datiloscrito em cópia carbono que mostra nos poemas $O$ medo, Nos áureos tempos, Assalto, Nova canção do exílio, Equivoco, Edificio São Borja, Idade madura, Cidade prevista, Indicações 1 etapa na escritura, e no poema Visão 944, 2 etapas na escritura: a-a $a_{1}$ :

a: datiloscrito completo;

$\mathrm{a}_{1}$ : rasura a tinta preta. 
2. A versão A confrontada com a versão B no livro Rosa do povo (ed. cit.), apresenta variantes nos poemas $O$ medo, Visão 944, Nos áureos tempos, Assalto, Equivoco, Edificio São Borja, Idade madura, Cidade prevista, Indicações.

MA - MOE, 42

ANDRADE, Carlos Drummond de (1902-1987)

42. Os últimos dias; poesia (MAd)

[Rio de Janeiro, ant. 1945]

Datiloscrito original, fita azul; papel branco; 2 folhas; 31,6 x 21,5 cm; vincos; sinais de fungo; ferrugem de clipe; escrita no anverso; rasuras a tinta preta; assinatura a máquina: "CARLOS DRUMMOND DE ANDRADE"; fólios numerados pela pesquisa: (1)-(2).

Notas de pesquisa:

1. Ms na vertente Mário de Andrade no diálogo interpares.

2. Data atestada com base no ano de publicação de Rosa do povo e o no da morte de MA.

3. Poemas publicados em Rosa do povo (ed. cit.).

Estudo genético:

1. No arquivo MA o ms apresenta-se em uma única versão, A, a cópia no datiloscrito que mostra 2 etapas na escritura: $a-a_{1}$ :

a: datiloscrito completo;

$\mathrm{a}_{1}$ : rasuras a tinta preta

2. A versão A confrontada com a versão B no livro Rosa do povo (ed. cit.). Há variantes.

MA - MOE, 43

ARANHA, Luís (Luís Aranha Pereira 1901-1987)

43. Drogaria de ether e de sombra; poesia (MAd)

São Paulo, 1921

Datiloscrito, cópia carbono azul: f. 1, 18, 20, carbono preto: f. 2-17, 19, 20; papel branco, filigrana: f. 1-17,19, 20; 20 folhas; f. 1: 21,6 x 16,5 cm, com variações em mm; vincos; f. 20: furo; f. 1-2, 19-20: marcas de ferrugem na margem superior; f. 1-3, 8, 10: riscos a lápis preto; folhas numeradas pelo escritor a máquina: 1-7, 9-20, a lápis: 8; escrita no anverso; f. 20: assinatura e data a máquina: "Luis Aranha | S. Paulo - 1921"; rasuras a máquina; fólios numerados pela pesquisa: (1)-(2) (1).

Notas MA: a lápis vermelho destacando estrofes e versos.

Notas da pesquisa:

1. Ms na vertente Mário de Andrade no diálogo interpares.

2. "Drogaria de éter e de sombra" integra Cocktails (São Paulo, Brasiliense, 1984) edição póstuma; estabelecimento do texto e notas de Nelson Ascher e Rui Moreira Leite. O 
livro reuniu todos os poemas nos ms conservados por MA e os publicados na revista do modernismo Klaxon, 1922-1923.

3. Sobre a poesia de Luís Aranha, MA escreveu o ensaio "Luís Aranha ou a poesia preparatoriana" (Revista Nova, $\mathrm{n}^{\circ}$ 7, São Paulo, 1932), também publicado em Aspectos da literatura brasileira (Rio de Janeiro, Americ= Edit., 1943). No ms do ensaio, composto de notas prévias, MA escreve à p. 53: "No primeiro em data dos seus três poemas longos, a Drogaria de Éter e de Sombra, escrito em fins de 1921, são numerosos os traços dessa poesia corretiva".

Estudo genético:

1. No arquivo MA o ms apresenta-se em uma única versão, A, o datiloscrito na cópia que mostra 2 etapas na escritura: a- $a_{1}$ :

a: datiloscrito completo;

$\mathrm{a}_{1}$ : rasuras a máquina

2. As observações MA a lápis preto no ms são notas prévias para o artigo "Luiz Aranha ou a poesia preparatoriana" (ed. cit.): indicação de trechos a serem citados e o lembrete, à folha 4, referente ao verso "Incendio na minha Biblioteca de Alexandrinos!...": "notar curiosa associação da Biblioteca de Alexan- | dria com Alexandrinos".

\section{MA - MOE, 44}

ARANHA, Luís (Luís Aranha Pereira 1901-1987)

44. Poema Pythagoras: poesia (MAd)

[São Paulo], 1922

Datiloscrito, cópia carbono azul; papel branco, pautado, filigrana: "Linho Paulista Superior"; 6 folhas; 27,6 x 21,2 cm; vincos; sinais de fungo; f. 6: marca de ferrugem; folha numerada a lápis preto: 1 ; folhas numeradas pelo escritor: a máquina 2-6; escrita no anverso; f. 6: autoria e data a máquina: "LUIS ARANHA | 1922"; rasuras a máquina; fólios numerados pela pesquisa: (1)-(6).

Notas MA a lápis vermelho: traços verticais à margem esquerda destacando trechos; a lápis preto: f. 4-5: sugestões de substituição; grifo em "quadro negro" no v. 8 da 2 a estrofe.

Notas da pesquisa:

1. Ms na vertente Mário de Andrade no diálogo interpares.

2. "Poema Pythagoras" integra Cocktails (ed. cit.): V. MA-MOE, 43, nota 2.

3. Sobre a poesia de Luís Aranha, MA escreveu o ensaio "Luís Aranha ou a poesia preparatoriana". V. MA-MOE, 43, nota 3.

\section{Estudo genético:}

1. No arquivo MA o ms apresenta-se em uma única versão, $\mathrm{A}$, o datiloscrito na cópia que mostra 2 etapas na escritura: a- $a_{1}$ :

a: datiloscrito completo;

$\mathrm{a}_{1}$ : rasuras a máquina. 


\section{MA - MOE, 45}

ARANHA, Luís (Luís Aranha Pereira 1901-1987)

45. Poema giratorio: poesia (MAd)

São Paulo, 1922

Datiloscrito original, fita preta; papel branco, filigrana: "Royal Bucks Vellum"; 21 folhas; 21,5/ 21,6 x 16,5 cm, com variações em mm; vincos; sinais de fungo; f. 1, 2021: ferrugem de clipe; folhas numeradas a máquina pelo escritor: 1-17, 19; escrita no anverso; f. 20: local e data: "S. Paulo 1922"; rasuras a máquina e a tinta preta (f. 13); fólios numerados pela pesquisa: (1)-(2) (1). F. 1: capa: autógrafo a tinta preta, autoria, título e data: "Luis Aranha", "Poema Giratorio", "1922". Nota de terceiros a lápis preto: "Alex Ferreira [?] | [?] Rodrigo Freitas".

Notas MA: a lápis vermelho: traços destacando trechos; a lápis preto: correções, sugestões de substituição.

Notas da pesquisa:

1. Ms na vertente Mário de Andrade no diálogo interpares.

2. "Poema giratório" integra Cocktails (ed. cit.) : V. MA-MOE, 43.

3. Sobre a poesia de Luís Aranha, MA escreveu o ensaio "Luís Aranha ou a poesia preparatoriana". V. MA-MOE, 43, nota 3.

Estudo genético:

1. No arquivo MA o ms apresenta-se em uma única versão, $\mathrm{A}$, o datiloscrito que mostra 3 etapas na escritura: $a-a_{1}-a_{2}$ :

a: datiloscrito completo;

$\mathrm{a}_{1}$ : rasuras a máquina

$\mathrm{a}_{2}$ : rasura a tinta preta.

MA - MOE, 46

ARANHA, Luís (Luís Aranha Pereira 1901-1987)

46. Cocktail; Telegramma; Minha amada; Poema pneumatico; poesia (MAd)

[São Paulo, 1922]

Datiloscrito, cópia carbono azul; papel branco, filigrana: "Royal Bucks Vellum"; 7 folhas; 22 x 16,5 cm: f. 2-6, 14,5/ 14,7 x 16,5 cm: f. 7; sinais de fungo; letras borradas; f. 3-6: furo e ferrugem de grampo; f. 3: ferrugem de clipe; escrita no anverso; f. 6: parte inferior retirada suprimindo anotações a lápis; rasuras a máquina e a lápis preto; fólios numerados pela pesquisa: (1)-(6). Notas MA. F. 1: Esboço de capa para projeto do livro Cocktail no verso da capa do programa da Semana de Arte Moderna de 1922 com desenho de Di Cavalcanti; papel branco, tipo cartolina, dobrado ao meio; 2 folhas; 25,3 $\mathrm{x} 16,5 \mathrm{~cm}$; sinais de fungo; vincos.

Notas MA: f. 1: "Poemas de Luís Aranha | (várias épocas)"; f. 2: "Aconselho-te a dormir sobre o livro - REFLEXÃO". 


\section{Cocktail:}

Notas MA a lápis preto: comentários e sugestão de substituição.

\section{Telegramma:}

Notas MA a lápis preto: comentários; destacamos: "Notavel pela via- | gem feita na cabe- | ça ao entrar no posto | telegrafico".

\section{Minha amada:}

Notas MA a lápis preto: comentários e observação na margem superior: "(citar sem as correções a | lapis)".

\section{Poema pneumatico; poesia (MAm)}

Notas MA: f. 2: a lápis vermelho: traço vertical na margem esquerda destacando trecho e a lápis preto comentário sobre o v. 14 da $3^{\mathrm{a}}$ estrofe e sugestão de substituição.

\section{Notas da pesquisa:}

1. Ms na vertente Mário de Andrade no diálogo interpares.

2. Data atestada com base no artigo de MA "Luiz Aranha ou a poesia preparatoriana" (Revista Nova, ed. cit.), também publicado em Aspectos da literatura brasileira (ed. cit.). MA cita alguns poemas dos ms de LA e relata: "Enfim já no acabar desse ano de 1922, o poeta me aparecia com um livro a que, pelos cacoetes da época, dera o nome de Cocktails". Pode-se deduzir que se trata do conjunto de ms acima classificado.

3. O ms do ensaio "Luiz Aranha ou a poesia preparatoriana", no Arquivo Mário de Andrade, no IEB-USP, guarda na f. 12 a anotação de MA referente à nota que ele traçara no ms de LA: "Citar o grifo | em vermelho do Poema Pneu- | matico, pra mostrar a perfeita | elasticidade lirica com que | o poeta se move dentro da | associação. Nesse trecho | há associações sonoras (qua- | rani guaraná), associações | de imagens visuais (vitrina $=\mid$ palco), associações de ideas $\mid($ palco $=$ prima-dona - guaraní - fôrma indomita), ainda associa- $\mid$ ções jornalescas (vitrine represen- $\mid$ tando quarto de cama = drama | de adulterio)."

4. A análise da capa mostra que o poeta, após fevereiro de 1922, ao entregar os ms a MA, no interior de uma capa do programa da Semana de Arte Moderna, acontecimento daquele mês e daquele ano, criou na parte inferior um vinco de proteção para os fólios. MA, após a leitura crítica dos textos de LA, fez o seu esboço de capa para o futuro livro no verso da capa que continha os ms recebidos, ignorando o vinco da margem inferior.

5. Os poemas integram Cocktails (ed. cit.): V. MA-MOE, 43, nota 2.

\section{Estudo genético:}

1. O ms apresenta-se em uma única versão, A, que mostra em Minha amada 1 etapa na escritura e nos demais poemas 2 etapas na escritura: $a-a_{1}$ : a: datiloscrito completo; $\mathrm{a}_{1}$ : rasuras a máquina.

2. A observação MA no poema Minha Amada, "(citar sem as correções a lapis)", é nota prévia para o artigo "Luiz Aranha ou a poesia preparatoriana" (ed. cit.) (V. MA-MOE, 43 , nota 3$)$. 
TELEGRAMMA

Vin telegraphar

Devo partir

O telegrapho bate

Na estação

Dentro das grades do elevador o empregado é prisioneiro Nanobras na sua cella

\section{$S \underset{163}{P} R$}

A campainha manda um som tremido

E o chefe saccode a bandeirola

Api to

Os ferros gritos

Choque de vagões

Locomotiva koloch

Na ponte lindo manto de pelies

Tu não morreste por ter tocado o zaimph de Tanit como 8alasmbô

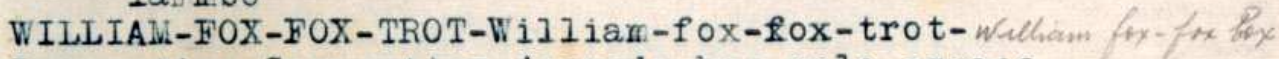

Locomotiva Carpentier jogando box pelo espaço

Só dás uppercuts

Com tuas luvas de ferro

As carpainhas das estações rarcam os rounds

Teu ring é o mundo

Xuixixixixixx

Soffro a vaia da locomotiva como no Theatro Municipal

Diz-se impropriamente que sou futurista

Impressões

Erros da geometria euclydeana

Os trilhos não são parallelas e se encontram antes do infinito

$\mathrm{Na}$ porteira todos esperam

Lavadeira a mulher de Atlas suspende o mundo áș costas

(Pede-se trazer o dinheiro certo para facilitar o troco 2 )

Vim telegraphar

Parto pelo ultino trem

Espere-re na estação (1)

Luis Aranha

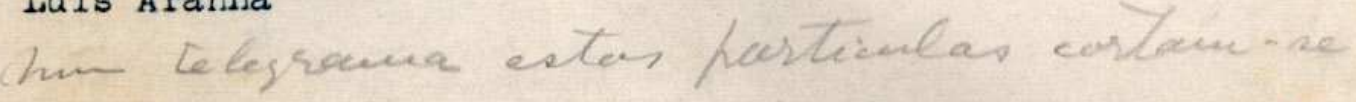
(2) Aio diverio écito na ha träco. 


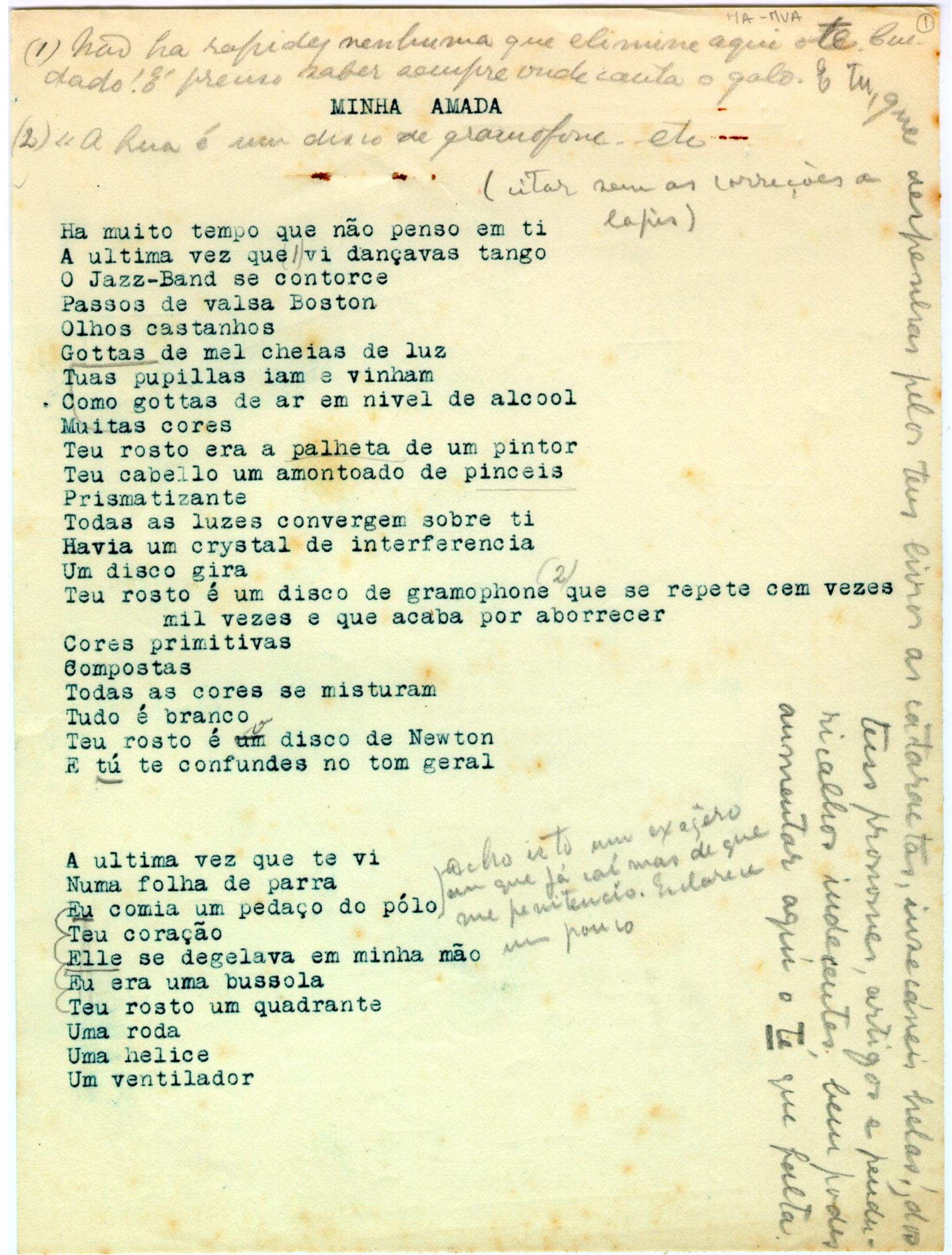


Fui um discobolo

Meu disco.

Agora tú és a lua

De tempo em tempo desäpareces

Sumiste

Não estás aqui

Nem em parte alguma

E como não te amo mais

Vou incluir este poema no meu livro cockTAILS

imilactao de beudrard, autes mimetienco. Trauxportarte tia presonabiade para decto ola. perconali dade de beadrar - o que i un apiso

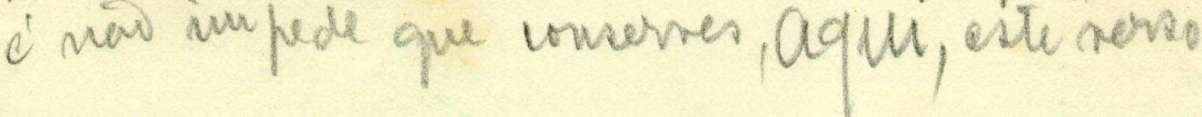




\section{MA - MOE, 47-61}

ARANHA, Luís (Luís Aranha Pereira 1901-1987)

47. $O$ vento; poesia (MAd)

[São Paulo, 1921-1922]

Datiloscrito, cópia carbono preto; papel branco, filigrana: "Royal Bucks Vellum"; 1 folha; 32,9 x 21,6 cm; margem superior: amassados; vincos; sinais de fungo; escrita no anverso; rasuras a máquina e a tinta preta; fólio numerado pela pesquisa: (1).

Notas MA: a lápis vermelho: traço vertical à margem esquerda destacando todo o poema; a lápis preto: observação e número na margem superior à direita: "12".

48. Os amores do vento; poesia (MAd)

[São Paulo, 1921-1922]

Datiloscrito, cópia carbono preto; papel branco, filigrana: "Royal Bucks Vellum"; 1 folha; 21,6 x $13 \mathrm{~cm}$; borda superior: 1 rasgamento; sinais de fungo; escrita no anverso; fólio numerado pela pesquisa: (1).

Notas MA a lápis preto: sugestão de acréscimo de vírgulas e número na margem superior à direita: “3”.

49. Tico-tico; poesia (MAd)

[São Paulo, 1921-1922]

Datiloscrito, cópia carbono preto; papel branco, filigrana: "Royal Bucks Vellum"; 1 folha; 11,3 x 11,9 cm; vincos; sinais de fungo; escrita no anverso; rasura a máquina; fólio numerado pela pesquisa: (1).

Nota MA a lápis preto: número na margem superior, à direita: "4".

50. Nocturno; poesia (MAd)

[São Paulo, 1921-1922]

Datiloscrito, cópia carbono preto; papel branco, filigrana: "Royal Bucks Vellum"; 1 folha; 19,3/ 19,4 x 15,3/ 15,4 cm; sinais de fungo; escrita no anverso; fólio numerado pela pesquisa: (1).

Notas MA: a lápis vermelho: traço vertical à margem esquerda destacando a $4^{\mathrm{a}}$ estrofe; a lápis preto: sugestões de substituição, número na margem superior, à direita: "5 A", e comentário.

51. Canção das nevôas; poesia (MAd)

[São Paulo, 1921-1922]

Datiloscrito, cópia carbono preto; papel branco, filigrana: "Royal Bucks Vellum"; 1 folha; 21,1 x 14,8/ 14,9 cm; vinco; sinais de fungo; escrita no anverso; fólio numerado pela pesquisa: (1).

Nota MA a lápis preto: número na margem superior, à direita: "5". 
52. Vagalume; poesia (MAd)

[São Paulo, 1921-1922]

Datiloscrito, cópia carbono preto; papel branco, filigrana: "Royal Bucks Vellum"; 1 folha; 21,6 x 13,3/ 13,4 cm; sinais de fungo; escrita no anverso; fólio numerado pela pesquisa: (1).

Nota MA a lápis preto: número na margem superior à direita: "6".

53. Estellario; poesia (MAd)

[São Paulo, 1921-1922]

Datiloscrito, cópia carbono preto; papel branco, filigrana: "Royal Bucks Vellum"; 1 folha; 21,6 x 13,1 cm; sinais de fungo; mancha de carbono ao lado do título; escrita no anverso; fólio numerado pela pesquisa: (1).

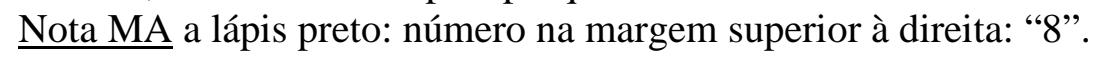

54. Epigramma á lúa; poesia (MAd)

[São Paulo, 1921-1922]

Datiloscrito, cópia carbono preto; papel branco, filigrana: "Royal Bucks Vellum"; 1 folha; 21,6 x 13,6/ 13,8 cm; vinco; sinais de fungo; escrita no anverso; fólio numerado pela pesquisa: (1).

55. Passeio; poesia (MAd)

[São Paulo, 1921-1922]

Datiloscrito, cópia carbono preto; papel branco, filigrana: "Royal Bucks Vellum"; 1 folha; 21,5/ 21,6 x $14 \mathrm{~cm}$; vinco; sinais de fungo; escrita no anverso; rasura a máquina; fólio numerado pela pesquisa: (1).

56. Canção de um louco; poesia (MAd)

[São Paulo, 1921-1922]

Impresso; 1 folha; recorte de revista; 12,4/ 12,5 x 9,6/ 10,1 cm; bordas esquerda, superior e direita irregulares; sinais de fungo; margem inefrior direita: autoria: "Luis Aranha"; fólio numerado pela pesquisa: (1).

Notas MA a lápis preto: número na margem superior à esquerda: “2”, e sugestões de substituição.

57. Vigilia; poesia (MAd)

[São Paulo, 1921-1922]

Datiloscrito, cópia carbono preto; papel branco, filigrana: "Royal Bucks Vellum"; 1

folha; 32,9 x 21,6 cm; vincos; sinais de fungo; escrita no anverso; rasura a tinta preta; fólio numerado pela pesquisa: (1).

Nota MA a lápis preto: número na margem superior à direita: "1", e comentário sobre o v. 1 da $3^{\text {a }}$ estrofe (“A pendula do relogio"): "Do que seria sinão do relogio?". 
58. As patas dos cavallos; poesia (MAd)

[São Paulo, 1921-1922]

Datiloscrito, cópia carbono preto; papel branco, filigrana: "Royal Bucks Vellum"; 1 folha; 15,4 x 16,4 cm; vincos; sinais de fungo; escrita no anverso; fólio numerado pela pesquisa: (1).

Notas MA a lápis preto: sugestão de substituição e número colocado na margem superior à direita: "9".

59. $O$ trem; poesia (MAd)

[São Paulo, 1921-1922]

Datiloscrito, cópia carbono preto; papel branco, filigrana: "Royal Bucks Vellum"; 1 folha; 26,9/ 27,1 x 16/ 16,2 cm; vinco; parte superior amassada; 1 furo; sinais de fungo; escrita no anverso; rasuras a máquina; fólio numerado pela pesquisa: (1).

Nota MA: a lápis vermelho: traço vertical à margem esquerda destacando trecho; a lápis preto: número na margem superior à direita: "10".

60. O tunnel; poesia (MAd)

[São Paulo, 1921-1922]

Datiloscrito, cópia carbono preto; papel branco, filigrana: "Royal Bucks Vellum"; 1 folha; 32,9 x 22,1 cm; borda esquerda irregular; vinco; sinais de fungo; escrita no anverso; rasura a máquina; fólio numerado pela pesquisa: (1).

Notas MA: a lápis vermelho: traço vertical à margem esquerda destacando as duas últimas estrofes; a lápis preto: número na margem superior à esquerda: "11", e sugestão de supressão de uma das duas epígrafes e comentário à palavra "wagons" no v. 3 da $4^{\text {a }}$ estrofe: "Porque não vagões? Tens medo?".

61. A ponte; poesia (MAd)

[São Paulo, 1921-1922]

Datiloscrito, cópia carbono preto; papel branco, filigrana: "Royal Bucks Vellum"; 1 folha; 32,9 x 22,1 cm; vinco; sinais de fungo; escrita no anverso; rasuras a máquina; fólio numerado pela pesquisa: (1).

Notas MA a lápis preto: número na margem superior à direita: "12", e sugestões de substituição, entre elas a que se refere a "Eil-o" no v. 8 da 5 a estrofe: "Este <<ei-lo〉> é horrivel, didatico".

Notas da pesquisa:

1. Ms na vertente Mário de Andrade no diálogo interpares.

2. A data 1921-1922 foi atestada com base em informação no artigo de MA "Luiz Aranha ou a poesia preparatoriana" (ed. cit.): "Com Luís Aranha se deu um fenômeno comuníssimo: mandou a arte à fava e se fez burguês mansinho. [...] Faz justo dez anos que emudeceu". O artigo foi escrito em 1931.

3. Os poemas integram Cocktails (ed. cit.): V. MA-MOE, 43, nota 2.

4. A numeração nas Notas MA pode ser compreendida como uma sugestão para a seqüência dos poemas no momento da publicação. 
Estudo genético:

1. No arquivo MA os ms apresentam-se em uma única versão, A, o datiloscrito em cópia carbono.

2. Minha amada, As patas dos cavallos, Os amores do vento, Nocturno, Canção das nevôas, Vagalume, Estellario, Epigramma á lúa, Canção de um louco mostram 1 etapa na escritura.

3. Cocktail, Poema pneumatico, O trem, O tunnel, A ponte, Tico-tico, Passeio mostram 2 etapas na escritura: $a-a_{1}$ :

a: datiloscrito completo;

$\mathrm{a}_{1}$ : rasuras a máquina.

4. Vigilia mostra 2 etapas na escritura: $\mathrm{a}-\mathrm{a}_{1}$ :

a: datiloscrito completo;

$\mathrm{a}_{1}$ : rasura a tinta preta.

5. Telegramma mostra 3 etapas na escritura: $\mathrm{a}-\mathrm{a}_{1}-\mathrm{a}_{2}$ :

a: datiloscrito completo;

$\mathrm{a}_{1}$ : rasuras a máquina;

$\mathrm{a}_{2}$ : rasuras a lápis preto.

6. O vento mostra 3 etapas na escritura: $\mathrm{a}-\mathrm{a}_{1}-\mathrm{a}_{2}$ :

a: datiloscrito completo;

$\mathrm{a}_{1}$ : rasuras a máquina;

$\mathrm{a}_{2}$ : rasuras a tinta preta.

7. Há Notas MA que valem como notas prévias para o artigo "Luiz Aranha ou a poesia preparatoriana" (ed. cit.). (V. MA-MOE, 43, nota 3).

\section{MA - MOE, 62}

\section{AUTO, José}

62. Aspiração; Canção de marinheiro morto; Music hall; Planicie; Poema de amor; Poema; Poema em 2 planos; Recordação do descanso noturno; poesia (MAm)

S/ local, s/ data

Datiloscrito, cópia carbono roxo; papel branco; 7 folhas; $21,3 \times 14,0$; vincos; sinais de fungo; letras borradas; f. 2: mancha de tinta azul na borda esquerda; f. 4: mancha de tinta azul na borda inferior à esquerda; escrita no anverso; assinatura a máquina: "José Auto.”; fólios numerados pela pesquisa: (1)-(7).

Nota da pesquisa:

1. Ms na vertente Mário de Andrade mentor.

\section{Estudo genético:}

1. No arquivo MA o ms apresenta-se em uma única versão, A, o datiloscrito, cópia, carbono.

2. Aspiração, Music hall, Poema em 2 planos, Recordação do descanso noturno mostram 1 etapa na escritura. 
3. Planicie e Poema de amor mostram 2 etapas na escrituras: $\mathrm{a}-\mathrm{a}_{1}$ :

a: datiloscrito completo;

a: rasura a máquina.

4. Canção de marinheiro morto e Poema mostram 2 etapas na escritura: a- $\mathrm{a}_{1}$ :

a: datiloscrito completo;

$\mathrm{a}_{1}$ : rasuras a tinta preta.

\section{MA - MOE, 63}

BANDEIRA, Manuel (Manuel Carneiro de Sousa Bandeira Filho 1886-1968)

63. Soneto; poesia (MAd)

[Mosela, Petrópolis, ant. 7 de mar. de 1923]

Autógrafo a tinta preta; papel branco, pautado; 1 folha; 32,2 x 22,8 cm; rasgamentos na borda direita, rasgamento dividindo a folha em duas partes; vincos; sinais de fungo; escrita no anverso; rasura a tinta preta; fólio numerado pela pesquisa: (1).

Notas da pesquisa:

1. Ms na vertente Mário de Andrade no diálogo interpares.

2. Data e local atestados pela carta de MB a MA de Mosela, 7 de março de [1923]. O remetente comenta a criação do livro $O$ ritmo dissoluto e o envio de Soneto: "Tenho feito aqui algumas coisas, a que quero dar o título de $O$ ritmo dissoluto. Mas vai saindo aos pouquinhos, como rolha podre. Veja esta impressão de melancolia e spleen a que por calculada sacanagem chamei 'SONETO' (o soneto não é uma composição de 2 quartetos e 2 tercetos, rimado o $1^{\circ}, 4^{\circ}, 5^{\circ}$ e $8^{\circ}$ versos, etc., etc. O essencial no soneto é um certo equilíbrio de estrofes, e eu fiz o meu poema, sentindo-o como um soneto e distribuindo convenientemente para realizar as massas rítmicas)" (Correspondência Mário de Andrade \& Manuel Bandeira. Marcos Antonio de Moraes (org.). 2.ed. São Paulo, Edusp/IEB, 2001, p, 86)

3. Soneto integra $O$ ritmo dissoluto em Poesias (Rio de Janeiro, Ed. da Revista de Língua Portuguesa, 1924). Poesias escolhidas (Rio de Janeiro, Civilização Brasileira, 1937) traz o poema com o título "Noturno de Mosela".

4. Sobre Poesias (ed. cit.) MA escreveu "Manuel Bandeira" na Revista do Brasil, em novembro de 1924.

Estudo genético:

1. O ms apresenta-se em uma única versão, A, que mostra 2 etapas na escritura: $a-a_{1}$ : a: autógrafo completo;

$\mathrm{a}_{1}$ : rasura a tinta preta.

2. Versão A confrontada com a versão B, em $O$ ritmo dissoluto (ed. cit.), mostra variantes. O confronto feito por Telê Ancona Lopez está na coletânea por ela coordenada, Manuel Bandeira: verso e reverso. São Paulo, TA Queiroz/FAPESP, 1987, p. 160-163. 


\section{MA - MOE, 64}

BANDEIRA, Manuel (Manuel Carneiro de Sousa Bandeira Filho 1886-1968)

64. Na Rua do Sabão; poesia (MAd)

[Petrópolis, ant. 31 maio 1923]

Autógrafo a tinta preta; papel branco; 3 folhas; $26,2 \times 20,5 \mathrm{~cm}$; rasgamentos nas bordas; vincos; sinais de fungo; escrita no anverso; f. 1: risco a lápis vermelho; folhas numeradas pelo escritor: 2-3; f. 3: assinatura: "Manuel Bandeira"; f. 1: rasura a tinta preta; fólios numerados pela pesquisa: (1)-(3).

\section{Notas da pesquisa:}

1. Ms na vertente Mário de Andrade no diálogo interpares.

2. A carta a MB, de São Paulo, 7 de junho [de 1923], mostra que naquela data MA tinha em mãos o ms: "Esqueci de dizer do teu poema 'Os meninos carvoeiros' que só a 'Rua do sabão' o ultrapassa" (Correspondência Mário de Andrade \& Manuel Bandeira, ed. cit., p. 96). Não havendo menção ao envio ou recebimento do ms ao longo da correspondência trocada entre ambos, o local e a data foram atestados com base nesta missiva.

3. Na Rua do Sabão integra $O$ ritmo dissoluto em Poesias (ed. cit.)

4. Sobre Poesias MA escreveu "Manuel Bandeira" na Revista do Brasil, em novembro de 1924.

Estudo genético:

1. O ms apresenta-se em uma única versão, $A$, que mostra 2 etapas na escritura: $a-a_{1}$ : a: autógrafo completo;

$\mathrm{a}_{1}$ : rasura a tinta preta.

2. Versão A confrontada com a versão B, em Poesias (ed. cit.) mostra variantes. O confronto feito por Telê Ancona Lopez está na coletânea por ela coordenada: Manuel Bandeira: verso e reverso. São Paulo, TA Queiroz/FAPESP, 1987, p. 136-141.

\section{MA - MOE, 65-66}

BANDEIRA, Manuel (Manuel Carneiro de Sousa Bandeira Filho 1886-1968)

65. Sob o céu todo estrelado; poesia (MAd)

[Petrópolis, ant. 31 maio 1923]

Autógrafo a tinta preta; papel branco, timbrado em relevo: "ARIESPHINX", filigrana; 1 folha; 28,1/28,2 x 21,1/21,2 cm; vincos; sinais de fungo; escrita no anverso; rasura a tinta preta; fólio numerado pela pesquisa: (1).

66. Os meninos carvoeiros; poesia (MAd)

[Petrópolis, ant. 31 maio 1923]

Autógrafo a tinta preta; papel branco, timbrado em relevo: "ARIESPHINX"; 1 folha; 26,2 x 20,5/20,6 cm; rasgamento na borda superior à direita; vincos; sinais de fungo; escrita no anverso; fólio numerado pela pesquisa: (1). 
Notas da pesquisa:

1. Ms na vertente Mário de Andrade no diálogo interpares.

2. Data e local atestados com base nas cartas trocadas entre MA e MB. Na primeira datada de Petrópolis, em 31 [de maio de 1923], MB trata do enviou de ms a MA: "Mando-te duas coisas minhas com um grande abraço"; a resposta de MA, em 7 de junho [de 1923], acusa o recebimento de Sob o céu todo estrelado e Os meninos carvoeiros: "'Sob o céu todo estrelado...' Fiquei indeciso: devia sorrir? Ironia? Se assim, tem um chiste, direi doce, delicioso. É isso. Compreendi teu poema? E a alusão a outro amigo? Mas por quê? Dize-me que foi ironia sem maldade. Pesar-me-ia que fosses perverso com alguém que te estima [...] Esqueci de dizer do teu poema 'Os meninos carvoeiros' que só a 'Rua do sabão' o ultrapassa. É UMA DELÍCIA" (Correspondência Mário de Andrade \& Manuel Bandeira, ed. cit., p. 95-96).

3. O diálogo sobre a criação de Os meninos carvoeiros estendeu-se na correspondência dos dois poetas. É o que revela a missiva de MB, em 27 de julho de 1923: "Acabo de receber a tua carta de 25 . Vejo que se perdeu a minha carta anterior, [...] Na mesma carta fazia-te uma consulta sobre o vocábulo chouteira que empreguei nos 'Meninos carvoeiros'. Não existe Chouteira no sentido de chicote. Chouteira é andadura de cavalo; e também andaço. Teria surgido no meu subconsciente por corruptela de açouteira? Que devo fazer? Ponho açouteira ou peia?" (Correspondência Mário de Andrade \& Manuel Bandeira. Ed. cit., p. 97)

4. Em 5 [de agosto de 1923] MA responde: "Agora para acabar, tua pergunta. 'E vão tocando os animais com uma chouteira enorme'. Primeiro: ainda não consegui descobrir se escreveste chouteira ou chouteria. As duas vezes que caligrafaste a palavra fizeste-o de tal forma que por mim não pude resolver da colocação do erre. Entendi o verso doutra forma, que os meninos tocavam os animais e que estes caminhavam num chouto pesado. Vejo agora que a tal palavra queria significar o açoite de que os meninos se serviam. Acho que deves substituir o termo. Ninguém poderá jamais compreender tua intenção, pois além de inventares um termo, dás-lhe um sentido que as fontes não autorizam. Sê tradicional. Hoje estou nisto. Vê minha crônica no número de agosto da Revista do Brasil. Vê mais o trecho da Escrava que sairá no número de setembro da América Brasileira. Verás nela o que penso sobre o tradicionalismo e sobre o hermeticismo. Sei muito bem a repugnância que nos dá, a nós - poetas de nós, qualquer concessão feita aos outros. E essa concessão é necessária, entretanto. É preciso acabar com esse individualismo orgulhoso que faz de nós deuses e não homens. Hoje sou muito humilde. Meu maior desejo é ser homem entre os homens. Transfundir-me. Amalgamar-me. Ser entendido. Sobretudo isso. QUERO SER ENTENDIDO. Porque se é verdade que Deus me deu alguma coisa de superior, é um desejo que os outros beneficiem dessa coisa. Não me atrai a volúpia de ser só. Aceito o que me dão e dou-me em troca" (Correspondência Mário de Andrade \& Manuel Bandeira, ed. cit., p. 101). A este trecho da carta, soma-se a nota de MB explicando como resolvera a questão da escolha do termo apropriado: "Emendei para 'relho"” (idem, ibdem, nota 51).

5. Sob o céu todo estrelado e Os meninos carvoeiros integram $O$ ritmo dissoluto, em Poesias (ed. cit.).

6. Sobre Poesias (ed. cit.) MA escreveu "Manuel Bandeira" na Revista do Brasil, em novembro de 1924.

7. A respeito da elaboração de $O$ ritmo dissoluto: V. MA-MOE, 63, nota 2. 
Estudo genético:

1. Os ms apresentam-se em uma única versão, A.

2. Sob o céu todo estrelado mostra 2 etapas na escritura: $\mathrm{a}-\mathrm{a}_{1}$ : a: autógrafo completo; $\mathrm{a}_{1}$ : rasura a tinta preta.

3. Os meninos carvoeiros mostra 1 etapa na escritura.

4. Versão A confrontada com a versão B em Poesias (ed. cit.). existe variantes em $O s$ meninos carvoeiros apresentam variantes. As duas versões de Sob o céu todo estrelado não apresentam variantes. O confronto feito por Telê Ancona Lopez está na coletânea por ela coordenada: Manuel Bandeira: verso e reverso. São Paulo, TA Queiroz/FAPESP, 1987, p. 132-135, 157-159.

\section{MA-MOE, 67}

BANDEIRA, Manuel (Manuel Carneiro de Sousa Bandeira Filho 1886-1968)

67. Camelots; poesia (MAd)

Rio de Janeiro, 2 dez. [1924]

Ms no corpo do fragmento de carta de MB a MA; datada: "Rio, 2 dez."; assinada: "M"; autógrafo a tinta preta; papel branco, 3 folhas (aparas de jornal); 22,6/22,8 x 8,9/9,1 cm; rasgamentos: f. 1: canto direito inferior, f. 3: borda esquerda; vinco; sinais de fungo; escrita no anverso; folhas numeradas pelo escritor: 5-7; fólios numerados pela pesquisa: (1)-(3).

Notas MA: a lápis vermelho: f. 2: grifo no verso: "chi que engraçado!"; a lápis preto: f. 3: acréscimo de vírgula no v. 9, após a palavra "meu filho".

(Ref. cruzada: série Correspondência Mário de Andrade - sub-série Correspondência passiva; MA-C-CPL, no 985).

Notas da pesquisa:

1. Ms na vertente Mário de Andrade no diálogo interpares.

2. Para criar Camelots MB inspirou-se em "Cenas de crianças", poma de MA que recebera junto da carta, de São Paulo em 31 de outubro de 1924: "Aqui vão Primeiro andar e 'Cenas da crianças'. Estas foram escritas como férias à Paulicéia no mês seguinte do da escritura primeira e tumultuária desta. Não lhes dou a mínima importância e nunca as publicarei creio" (Correspondência Mário de Andrade \& Manuel Bandeira, ed. cit., p. 142). MA não o publicou nem preservou o ms.

3. Na carta datada do Rio de Janeiro, 2 de dezembro de [1924], na qual MB enviou a MA Camelots, está o relato: "Tinha feito uns versos, onde descubro que há uma coisa sua. Naturalmente me ficou da leitura que você fez dos 'Kinderszenen' em casa do Ronald. § Como você não pretende publicar as "Cenas', venho pedir-lhe licença para o plágio" (Correspondência Mário de Andrade \& Manuel Bandeira, ed. cit., p. 158), Na mesma carta está a pergunta: "Me dá aquele 'chi que engraçado'?", certamente pedindo um verso de "Cenas de crianças" para Camelots. Em atenção a esse pedido, MA grifou no ms, a lápis vermelho, o referido verso. Esta carta e sua resposta convalidam o diálogo da criação na correspondência MA \& MB. Na resposta de MA, em [16 de dezembro de 1924] se lê: “- O 'Chi que engraçado!' afinal de contas não é meu, Manuel. Toda a 
gente diz isso no Brasil. Eu já em vários artigos empreguei o que engraçado, mesmo no sobre ti sai um 'Engraçado!', estou me lembrando. 'Camelôs' é uma delícia. Conserva o 'Chi, que engraçado' que é de toda a gente." (Correspondência Mário de Andrade \& Manuel Bandeira, ed. cit., p. 161). Sobre o emprego do verso, MB alega: "Em meu poema 'Camelôs' empreguei a expressão 'Chi, que engraçado!' e ela me pareceu no momento demasiado coisa do Mário. Quis suprimi-la e consultei o amigo. As razões me convenceram, conservei." (Correspondência Mário de Andrade \& Manuel Bandeira. Ed. cit., nota 135). Conservou em parte, pois na $1^{\text {a }}$ edição de Libertinagem (Rio de Janeiro, Paulo, Pongetti\& C.), em 1930, o v. 6 de Camelots é: "A perereca verde que de repente dá um pulo que engraçado" (p.15).

4. Há dois exemplares de Libertinagem na biblioteca MA. O primeiro com Notas MA a lápis selecionando alguns poemas; o segundo, com as folhas dos cadernos não separadas pela espátula de MA, guarda na folha de ante-rosto a dedicatória: "Ao querido Mario, I of. | Manuel | 1930". Assim acontece porque MA bibliófilo costumava guradar intactos os exemplarescom dedicatória, adquirindo ou reavendo um segundo exemplar no qual exercia sua leitura de crítico, anotando a lápis. Quando souberam disso, vários autores passaram a lhe oferecer dois exemplares das obras.

5. A crônica de MA: "Puro, sem mistura", Diário Nacional, 22 jun. 1930, trata de Libertinagem e Alguma poesia de Carlos Drummond de Andrade.

Estudo genético:

1. O ms apresenta-se em uma única versão, A, que mostra 1 etapa na escritura.

2. Versão A confrontada com a versão B em Libertinagem (ed. cit.). Há variantes.

3. O confronto das versões A e B ao lado da análise da correspondência evidencia a participação de MA na criação de MB, ocorrida no diálogo epistolar.

\section{MA-MOE, 68}

BANDEIRA, Manuel (Manuel Carneiro de Sousa Bandeira Filho 1886-1968)

68. Não sei dançar; Pensão familiar; Mulheres; poesia (MAd)

[Rio de Janeiro, 17 de abril de 1925]

Autógrafo a tinta preta; papel branco, filigrana; 1 folha; 33,1 x $21 \mathrm{~cm}$; vincos; sinais de fungo; escrita no anverso e no verso; fólio numerado pela pesquisa: (1).

Notas da pesquisa:

1. Ms na vertente Mário de Andrade no diálogo interpares.

2. Data atestada com base na correspondência trocada entre MA e MB. Na carta do Rio de Janeiro, 16 [de abril de 1925], MB explica não ter copiado ainda os poemas que prometera a MA. Em 17 de abril de 1925, nova missiva relata o envio de poemas, sem explicitar os títulos. A resposta de MA, em 18 de abril de 1925, comenta os poemas recebidos: "Li só uma vez os poemas de você. primeirra impressão deu plena, 8, pra 'Mulheres' e 'Pensão familiar', e distinção com louvor pro 'Não sei dançar'. Porém não digo que as notas fiquem essas. Deixe eu ler num dia mais meu e vai carta." (Correspondência Mário de Andrade \& Manuel Bandeira, ed. cit., p. 199-202).

3. Os três poemas foram publicados em Libertinagem (ed. cit.). 
6

eara do Rovalf. Coun. Voce na' metenre vublicar as scenas, veule. feosithe licenia bara o vajio. juegue vocé mes. mo de forde der.

Camelots

Cebencoado sepa o camelot sie vende brniquediubs de tostá. - que verde balóescithos de

- macaquinho que Trepa helo copueno - cachorsinbo ve bate 0) homensinhor que Jagak

A perereca verde que de refente da' un pulo, chi que engrapado!

2 as conctinhar-triteino que tamai, s-

97 
ereverà conc aljuma!

Alegria don calparas... Uns fram fulos cotovelo:

- O cavaltheir. Chega en casa e oj: men ficho, vai buscar un feda. eo de bounana hara in acender. cigasso. naturahnente o menino penaral: Pafai'esta' malu...

Outrn, critaon, têu a hugiua atadia.

Toin, poin, Jabem nexer nor cordéi com upuele timo vigémo de demiurgos de inutilidades.

$\varepsilon$ ensiatam no tumulto ras ruas os nitos hervicos da menimice.

I dai aos bomens sue frassom preocupraios on triites una liçás de rifancia.

the dä aquele "chi que engracaso?

Qias.

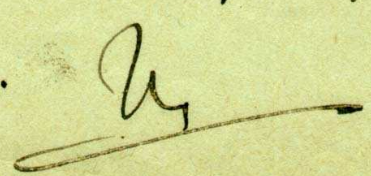

98 
4. Há dois exemplares de Libertinagem na biblioteca MA. O primeiro traz Notas MA a lápis selecionando poemas; o segundo, com as folhas dos cadernos não separadas pela espátula de MA, guarda na folha de ante-rosto a dedicatória: "Ao querido Mario, | of. | Manuel | 1930". Assim acontece porque MA bibliófilo costumava guradar intactos os exemplarescom dedicatória, adquirindo ou reavendo um segundo exemplar no qual exercia sua leitura de crítico, anotando a lápis. Quando souberam disso, vários autores passaram a lhe oferecer dois exemplares das obras.

5. Em 22 de junho de 1930 o Diário Nacional publicou a crônica de MA "Puro, sem mistura", que focaliza Libertinagem ao lado de Alguma poesia de Carlos Drummond de Andrade.

\section{Estudo genético:}

1. O ms apresenta-se em uma única versão, A, que mostra 1 etapa na escritura.

2. Versão A confrontada com a versão B, Libertinagem (ed. cit.), mostra variantes.

\section{MA - MOE, 69}

BANDEIRA, Manuel (Manuel Carneiro de Sousa Bandeira Filho 1886-1968)

69. Evocação do Recife; poesia (MAd)

Rio de Janeiro, 13 jul. 1925

Datiloscrito cópia, carbono preto; papel branco, filigrana; 2 folhas; 33,1 x $21,5 \mathrm{~cm}$; bordas esquerdas irregulares; vincos; sinais de fungo; escrita no anverso; f. 2: assinatura a tinta preta: "M.", local e data a máquina: "Rio, 13 de Julho de 1925"; rasuras a máquina e a tinta preta; fólios numerados pela pesquisa: (1)-(2).

Notas da pesquisa:

1. Ms na vertente Mário de Andrade no diálogo interpares.

2. Na carta escrita em Recife, 21 de julho de 1925 , MB relata a MA a criação do poema Evocação do Recife: "Eu andei fazendo uma 'Evocação do Recife' para o álbum comemorativo do centenário do Diário de Pernambuco. A pedido do Gilberto Freire que é um rapaz inteligentíssimo de lá. Você conhece-o? Mandou a ele a Escrava?" (Correspondência Mário de Andrade \& Manuel Bandeira, ed. cit., p. 220).

3. A resposta de MA, São Paulo, em 26 [de julho] de 1925, mostra interesse em conhecer Evocação do Recife: "Que diabo! ainda não chegou a máquina de você? Senão eu pedia pra você comprar papel carbono e tirar da 'Evocação do Recife', uma pra mim. Não conheço o Gilberto Freire e acho que não mandei meu livro pra ele". (Correspondência Mário de Andrade \& Manuel Bandeira, ed. cit., p. 221)

4. Em 3 de agosto [de 1925], o ms acompanha a carta escrita no Rio de Janeiro, na qual se lê: "Vai a 'Evocação do Recife'. Embora, já a tenha mandado, gostaria de ter comentário seu" (Correspondência Mário de Andrade \& Manuel Bandeira, ed. cit., p. 225). O pedido de opinião a MA é reiterado na missiva seguinte, também vinda do Rio em 19 de agosto [de 1925]: "Quando você puder, comente a 'Evocação'. Comentários assim, mesmo quando não alterem o pensamento da gente, aproveitam sempre: são verdadeiras experiências psicológicas [...], isto é, experiências em que a gente conhece 
bem o excitante e quer conhecer a reação do paciente" (Correspondência Mário de Andrade \& Manuel Bandeira. Ed. cit., p. 228).

5. MB recebeu comentários de MA sobre Evocação do Recife, em cartas de 22 de agosto de 1925 e [ant. 13 setembro de 1925]. Na última está: "Releio a 'Evocação'. É como tudo que você está fazendo nestes últimos tempos e que conheço. Uma delícia silenciosa. O que eu mais quero da sua poesia, tanto é certo que a gente mais quer o que não tem, é a extraordinária impressão de força e calma que dá.". (Correspondência Mário de Andrade \& Manuel Bandeira. Ed. cit., p. 232). Na mesma carta está a crítica ao poema "Quando minha irmã morreu" no ms que MA recebera de MB em, [post. 22 de agosto de 1925] (V. MA - MOE, 70).

6. Evocação do Recife foi publicado em Libertinagem (ed. cit.).

7. Há dois exemplares de Libertinagem na biblioteca MA. O primeiro com Notas MA a lápis selecionando alguns poemas; o segundo, com as folhas dos cadernos não separadas pela espátula de MA, guarda na folha de ante-rosto a dedicatória: "Ao querido Mario, | of. | Manuel | 1930". Assim acontece porque MA bibliófilo costumava guradar intactos os exemplarescom dedicatória, adquirindo ou reavendo um segundo exemplar no qual exercia sua leitura de crítico, anotando a lápis. Quando souberam disso, vários autores passaram a lhe oferecer dois exemplares das obras.

8. Em 22 de junho de 1930 o Diário Nacional publicou a crônica de MA "Puro, sem mistura", que focaliza Libertinagem ao lado de Alguma poesia de Carlos Drummond de Andrade.

Estudo genético:

1. O ms apresenta-se em uma única versão, A,que mostra 3 etapas na escritura: $a-a_{1}-a_{2}$ : a: datiloscrito completo;

$\mathrm{a}_{1}$ : rasuras a máquina;

$\mathrm{a}_{2}$ : rasura a tinta preta.

2. A versão A foi confrontada com a versão B em Libertinagem (ed. cit.), exibe variantes.

\section{MA - MOE, 70}

BANDEIRA, Manuel (Manuel Carneiro de Sousa Bandeira Filho 1886-1968)

70. "Quando minha irmã morreu"; poesia (MAd)

[Rio de Janeiro, post. 22 de agosto de 1925]

Ms no corpo da carta de MB a MA; [Rio de Janeiro, post. 22 de agosto de 1925]; assinada: "M. ."; forma de tratamento: "Mario -"; autógrafo a tinta preta; papel jornal; 1 folha (apara de jornal); 38,5/38,8 x 14,2/14,3 cm; rasgamentos nas bordas direita e esquerda; vincos; sinais de fungo; escrita no anverso; fólio numerado pela pesquisa: (1). Nota MA a lápis preto: v. 3: grifo em "para ao pé" e traço puxando a anotação na margem superior: "Paraopeba".

Notas da pesquisa:

1. Ms na vertente Mário de Andrade no diálogo interpares. 
2. Na carta, abaixo do poema, está a pergunta de MB a MA: "Como devo chamar isso? Você que andou em quartéis - como se chama o ato das sentinelas que se rendem?" (Correspondência Mário de Andrade \& Manuel Bandeira, ed. cit., p. 230).

3. A resposta de MA, de [São Paulo, ant. 13 de setembro de 1925] diz: "'Quando minha irmã morreu'. Outra delícia silenciosa. Só não gosto daquele 'para o pé' que você botou, talvez pra evitar a repetição de 'para junto' que vem dois versos depois. 'Para o pé' é horrível. Deve de ser lusitanismo. É feio em si e lembra paraopeba. Mude isso, porém cuidado em não perder agudo 'mim' acabando o verso. O grande achado inconsciente me parece dessa poesia está em que todos os versos, menos um, acabam em agudo. Acabam de supetão, a gente fica diante de um silêncio de abismo separando nitidamente um verso do outro. Estupendo." (Correspondência Mário de Andrade \& Manuel Bandeira, ed. cit., p. 232). Em carta do Rio de Janeiro, 13 de setembro de [1925], MB volta ao assunto: "O 'para ao pé' foi um pis-aller. Gosto de 'ao pé'. Acho tão juntinho! É popular que acha de ‘veio ficar ao pé de mim'? E o título? 'Sentinela rendida? Responda" (Correspondência Mário de Andrade \& Manuel Bandeira, ed. cit., p. 237).

4. MB, em carta a MA, de 19 de setembro de [1925], informa: "O meu poeminha sai no Globo de $2^{\mathrm{a}}$ feira. Chamei-o "O Anjo da Guarda". O Villa-Lobos me tinha feito a mesma advertência que você fez agora sobre a palavra 'rendida'" (Correspondência Mário de Andrade \& Manuel Bandeira. Ed. cit., p. 242).

5. "Quando minha irmã morreu" está em Libertinagem (ed. cit.) com o título "O anjo da guarda".

6. Há dois exemplares de Libertinagem na biblioteca MA. O primeiro traz Notas MA a lápis selecionando poemas; o segundo, com as folhas dos cadernos não separadas pela espátula de MA, guarda na folha de ante-rosto a dedicatória: "Ao querido Mario, | of. | Manuel | 1930". Assim acontece porque MA bibliófilo costumava guradar intactos os exemplarescom dedicatória, adquirindo ou reavendo um segundo exemplar no qual exercia sua leitura de crítico, anotando a lápis. Quando souberam disso, vários autores passaram a lhe oferecer dois exemplares das obras.

7. Em 22 de junho de 1930 o Diário Nacional publicou a crônica de MA "Puro, sem mistura", que focaliza Libertinagem ao lado de Alguma poesia de Carlos Drummond de Andrade.

8. Villa-Lobos musicou o poema "O Anjo da guarda". Em carta de $1^{\circ}$ de maio de [1926] MB encaminhou a MA uma cópia da partitura e o ms do poema Cordão de Dante Milano: "Com esta lhe mando sob registro uma cópia da música que o Villa escreveu prao 'Anjo da Guarda'. [...] O Villa musicou também a poesia do Dante. [...] Pra você conhecê-lo melhor, mando-lhe o 'Cordão' (devolva-me, não tenho cópia)" (Correspondência Mário de Andrade \& Manuel Bandeira, ed. cit., p. 288). V. análise documentária de Cordão, MA-MOE, 220.

Estudo genético:

1. O ms apresenta-se em uma única versão, A, que mostra 1 etapa na escritura.

2. Versão A confrontada com a versão B, em Libertinagem (ed. cit.). Há variantes.

3. O confronto feito por Telê Ancona Lopez está na coletânea por ela coordenada: Manuel Bandeira: verso e reverso. São Paulo, TA Queiroz/FAPESP, 1987, p. 164-168. 
Quando mitha miñ̃ morren - Denia ter biclo assin -

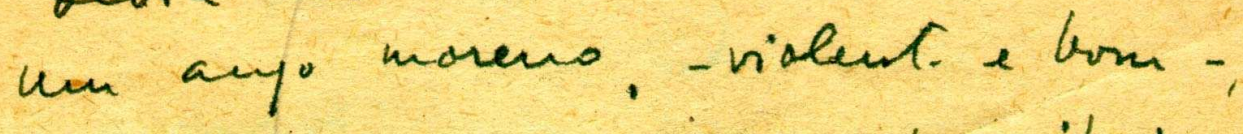
bran'lei.

veir tara as fé de cimin.

- men anjo da jwaria sarrin E volton rara fueto do Seuche...

lilario

como devo hamear sio!

voce pre auton en praste: comes te chanta o acto in sentinelas be se ver. ene?

"Liania" i estuenb_trculpe, man prants josto dieito ton conas ion epcentivo. I as

102 


\section{MA-MOE, 71}

BANDEIRA, Manuel (Manuel Carneiro de Sousa Bandeira Filho 1886-1968)

71. O Paulo; poesia (MAd)

[Rio de Janeiro, 1925 ou 1927]

Datiloscrito, cópia, carbono preto; papel tipo jornal; 1 folha; 28,0 x 21,5/21,6 cm; rasgamentos borda direita; vincos; sinais de fungo; escrita no anverso; assinatura a máquina: "Manuel Bandeira"; rasura a máquina; fólio numerado pela pesquisa: (1).

Notas da pesquisa:

1. Ms na vertente Mário de Andrade no diálogo interpares.

2. O poema em que MB parodia o prórpio poema "O cacto", celebra a presença de Paulo Ribeiro de Magalhães no Rio.

3. Telê Ancona Lopez (org.). Manuel Bandeira: verso e reverso. São Paulo, TA Queiroz/FAPESP, 1987, p. 175.

\section{Estudo genético:}

1. O ms apresenta-se em uma única versão, $A$, que mostra 2 etapas na escritura: $a-a_{1}$ : a: datiloscrito completo;

$\mathrm{a}_{1}$ : rasura a máquina.

\section{MA-MOE, 72}

BANDEIRA, Manuel (Manuel Carneiro de Sousa Bandeira Filho 1886-1968)

72. Madrigal monóstico em ritmo inumeravel; poesia (MAd)

[Rio de Janeiro, ant. 19 mar. 1926]

Autógrafo a tinta preta; papel branco dobrado ao meio formando 2 folhas; $20,1 \mathrm{x}$ 15,4/15,5 cm; vinco; sinais de fungo; f. 1: escrita no anverso, f. 2: em branco; assinatura: "Manuel Bandeira"; fólios numerados pela pesquisa: (1)-(2).

Notas da pesquisa:

1. Ms na vertente Mário de Andrade no diálogo interpares.

2. Data e local atestados com base na carta de MA a MB, de São Paulo, 19 de março de 1926, que traz o comentário: "E gostei sobretudo do tal 'Madrigal monóstico' que Germaninha me trouxe do Rio" (Correspondência Mário de Andrade \& Manuel Bandeira, ed. cit., p. 278).

3. Na carta a MA, do Rio de Janeiro em 23 de março de [1926], MB reclama: "Não gostei que o Dante tivesse dado o meu madrigal pra Germaninha. Isso me aporrinhou. Agora o mal está feito. Acabei uma carta assim. Depois vi que era um poema e mandei pro Dante com o título de 'Madrigal monóstico em ritmo inumerável'. Por caçoada. Mas aquilo deve se chamar 'Madrigal tão engraçadinho', não acha? Gosto muito dele porque recorda o meu porquinho da Índia, deslumbramento inesquecível da minha infância.". Em seguida, MB transcreve o poema que mais tarde, em Libertinagem (ed. cit.), levará 
o título "Porquinho da Índia" (Correspondência Mário de Andrade \& Manuel Bandeira. ed. cit., p. 280).

4. Madrigal monóstico em ritmo inumeravel foi publicado em Libertinagem (ed. cit.) com o título "Madrigal tão engraçadinho".

5. Há dois exemplares de Libertinagem na biblioteca MA. O primeiro traz Notas MA a lápis selecionando poemas; o segundo, com as folhas dos cadernos não separadas pela espátula de MA, guarda na folha de ante-rosto a dedicatória: "Ao querido Mario, | of. | Manuel | 1930". Assim acontece porque MA bibliófilo costumava guradar intactos os exemplarescom dedicatória, adquirindo ou reavendo um segundo exemplar no qual exercia sua leitura de crítico, anotando a lápis. Quando souberam disso, vários autores passaram a lhe oferecer dois exemplares das obras.

6. Em 22 de junho de 1930 o Diário Nacional publicou a crônica de MA "Puro, sem mistura", que focaliza Libertinagem ao lado de Alguma poesia de Carlos Drummond de Andrade.

Estudo genético:

1. O ms apresenta-se em uma única versão, A, que mostra 1 etapa na escritura.

2. Versão A confrontada com aversão B, em Libertinagem (ed. cit.), mostra variantes. $\mathrm{O}$ confronto feito por Telê Ancona Lopez está na coletânea por ela coordenada: Manuel Bandeira: verso e reverso. São Paulo, TA Queiroz/FAPESP, 1987, p. 169-171.

\section{MA-MOE, 73}

BANDEIRA, Manuel (Manuel Carneiro de Sousa Bandeira Filho 1886-1968)

73. Cunhatã ; poesia (MAd)

[Rio de janeiro, 09 abr. 1927]

Datiloscrito, cópia carbono preto; papel jornal; 1 folha; 27,1 x 20,9 cm; vincos; rasgamentos: na borda superior à esquerda e na borda esquerda; sinais de fungo; escrita no anverso; rasuras a tinta preta; assinatura a máquina: "Manuel Bandeira"; fólio numerado pela pesquisa: (1).

Notas da pesquisa:

1. Ms na vertente Mário de Andrade no diálogo interpares.

2. Data e local atestados com base na carta de MB a MA, Rio de Janeiro, 9 de abril de [1927]: "O 'Lundu está delicioso. Te pago mal com esta 'Cunhatãzinha', pela qual me apaixonei a bordo. Ela também se apaixonou por mim e vinha me fazer carinhos, festinhas no rosto e esfregava a cabeça no meu pescoço. Um amor que eu gostaria de adotar. Diga se você sentiu a menina" (Correspondência Mário de Andrade \& Manuel Bandeira. ed. cit., p. 343).

3. "Cunhatã" foi publicado em Libertinagem (ed. cit.).

4. Na carta a MA, do Rio de Janeiro em 23 de março de [1926], MB reclama: "Não gostei que o Dante tivesse dado o meu madrigal pra Germaninha. Isso me aporrinhou. Agora o mal está feito. Acabei uma carta assim. Depois vi que era um poema e mandei pro Dante com o título de 'Madrigal monóstico em ritmo inumerável'. Por caçoada. Mas aquilo deve se chamar 'Madrigal tão engraçadinho', não acha? Gosto muito dele porque 
recorda o meu porquinho da Índia, deslumbramento inesquecível da minha infância.". Em seguida, MB transcreve o poema que mais tarde, em Libertinagem (ed. cit.), levará o título "Porquinho da Índia" (Correspondência Mário de Andrade \& Manuel Bandeira. ed. cit., p. 280).

5. Há dois exemplares de Libertinagem na biblioteca MA. O primeiro traz Notas MA a lápis selecionando poemas; o segundo, com as folhas dos cadernos não separadas pela espátula de MA, guarda na folha de ante-rosto a dedicatória: "Ao querido Mario, | of. | Manuel | 1930". Assim acontece porque MA bibliófilo costumava guradar intactos os exemplarescom dedicatória, adquirindo ou reavendo um segundo exemplar no qual exercia sua leitura de crítico, anotando a lápis. Quando souberam disso, vários autores passaram a lhe oferecer dois exemplares das obras.

6. Em 22 de junho de 1930 o Diário Nacional publicou a crônica de MA "Puro, sem mistura", que focaliza Libertinagem ao lado de Alguma poesia de Carlos Drummond de Andrade.

Estudo genético:

1. O ms apresenta-se em uma única versão, A, que mostra 2 etapas na escritura: $a-a_{1}$ : a: datiloscrito completo;

$a_{1}$ : rasura a tinta preta.

2. Versão A confrontada com a versão B, em Libertinagem (ed. cit.). exibe variantes.

\section{MA - MOE, 74}

BANDEIRA, Manuel (Manuel Carneiro de Sousa Bandeira Filho 1886-1968)

74. Profundamente; A lagarta listada; poesia (MAd)

Rio de Janeiro, 22 ago. 1927

Poemas enviados por MB a MA no corpo da carta datada: "Rio, 22 agosto 1927"; assinada: "Manu."; forma de tratamento: "Mario."; autógrafo a tinta preta; papel branco, filigrana: "Selected bond"; 2 folhas; 26,9/27,1 x 20,8 cm; rasgamentos nas bordas; vincos; sinais de fungo; f. 1: escrita no anverso e no verso, f. 2: escrita no anverso; rasura a tinta preta; fólios numerados pela pesquisa: (1)-(2).

(Ref. cruzada: série Correspondência Mário de Andrade - sub-série Correspondência passiva; MA-C-CPMVA, $\mathrm{n}^{\circ}$ 1071)

Notas da pesquisa:

1. Ms na vertente Mário de Andrade no diálogo interpares.

2. Na carta de 22 de agosto de 1927, MB menciona apenas o poema A lagarta listada: "Ah! Fiz também este poeminha que ficará inédito" (Correspondência Mário de Andrade \& Manuel Bandeira, ed. cit., p. 349).

3. A resposta de MA vem em 30 de agosto de 1927: "Agora o da 'Teresa' [em referência à Lagarta listada] está mesmo uma obra-prima, é um colosso e gozei como ninguém mais não. [...] Não vá pensar não que de certo eu não gostei destes dois últimos poemas que você me mandou e é por dó que estou falando serem bons, não. Eu sou incapaz de dó pra com você porque primeiramente você não carece dele e em segundo é meu amigo. Gostei deveras e então da 'Teresa' como já falei acho sublime, só vendo como o 
último verso me tem andado na cabeça ecoando. Foi o verso que eu deveria ter falado pra Maria, deveria não, devo, agora que depois que ela me sentiu livre a diaba faz cada uma pra mim tão bonitinha e sorri quebrando a boca numa aberturinha que seria mesmo paisagem do céu. Maria, você é engraçada, Maria, você parece louca. Mas não sofro mais, já se foi o tempo." (Correspondência Mário de Andrade \& Manuel Bandeira. Ed. cit., p. 349-350).

4. MB encaminhou a MA nova versão de Lagarta listada, com o título Namorados (V. MA - MOE, 77).

5. Há referência a Profundamente na carta de MB a MA, do Rio de Janeiro, 3 de setembro de 1927: "Sim, Mário! é uma bruta felicidade essa de a gente poder fazer versos. Aquele 'Profundamente' fez a minha consolação durante bem uns quinze dias. Se Deus me desse uma coisa dessas de 15 em quinze dias eu aceitaria sem tanta amargura o meu destino". (Correspondência Mário de Andrade \& Manuel Bandeira. Ed. cit., p. 353)

6. Os poemas Profundamente; A lagarta listada, este com o título Namorados foram publicados em: Libertinagem (Rio de Janeiro, Paulo, Pongetti\& C., 1930).

7. Há dois exemplares de Libertinagem na biblioteca MA. O primeiro traz Notas MA a lápis selecionando poemas; o segundo, com as folhas dos cadernos não separadas pela espátula de MA, guarda na folha de ante-rosto a dedicatória: "Ao querido Mario, | of. | Manuel | 1930”. Assim acontece porque MA bibliófilo costumava guradar intactos os exemplarescom dedicatória, adquirindo ou reavendo um segundo exemplar no qual exercia sua leitura de crítico, anotando a lápis. Quando souberam disso, vários autores passaram a lhe oferecer dois exemplares das obras.

8. Em 22 de junho de 1930 o Diário Nacional publicou a crônica de MA "Puro, sem mistura", que focaliza Libertinagem ao lado de Alguma poesia de Carlos Drummond de Andrade.

\section{Estudo genético:}

1. O ms apresenta-se em uma única versão, A, que mostra, em Profundamente, 1 etapa na escritura e, em Lagarta listada, 2 etapas na escritura: a-a ${ }_{1}$ :

a: autógrafo completo

$\mathrm{a}_{2}$ : rasura a tinta preta.

2. Namorados é a segunda versão, B, de Lagarta listada; e apresenta variantes em relação à versão $\mathrm{A}$ (V. MA - MOE, 77).

3. A versão A de Profundamente foi confrontada com a versão B em Libertinagem (ed. cit.); mostra variantes.

4. A versão A de Lagarta listada foi confrontada com a versão C em Libertinagem (ed. cit.), e apresenta variantes.

5. O confronto feito por Telê Ancona Lopez está na coletânea coordenada pela mesma: Manuel Bandeira: verso e reverso. São Paulo, TA Queiroz/FAPESP, 1987, p. 142-150. 


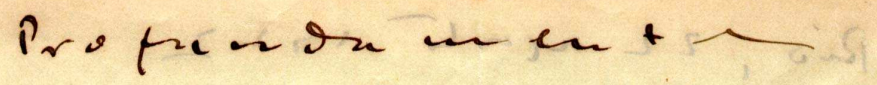

arands outean adermecs.

ma noite de S. poat

Harra alegrai e rumer luzes de Bengala Eutronos de koubas sios

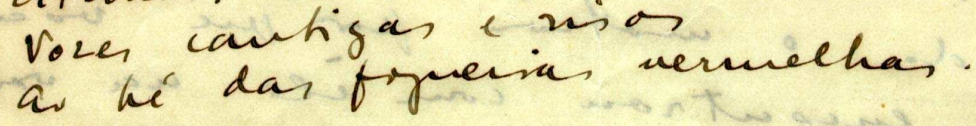

hi uneir da noite desperts. hai oni main vozes neen rios afinas balois Pasivara enantè silencion anente apenos de wer en pands - unide de sun tande Cortara onilence: corvo un tunel.

oudeletavam 1 we hai pones Dancavara

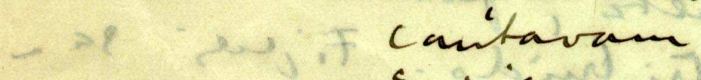

a. Fédar forgenas vermelhar?

Sitaram toin daraniveds utavam toin deitars darnesid Profucios acmenti

Auande en tiula bas and vai or ofine da fata de s. 70as rofue dorm:

the nai once main as vores daquele tenfe.

107 
Mintre awó men avi

Totorion Rasiges

Tomasia, Rosa

oude ation trin, íle?

Qutio torn dormind.

Gitai todon deitain

parmindo

irofunda mente.

ar fir temben she poenine ver ficara mies to

Lajanta listava-

Teren anisa ná me hallites coms sen

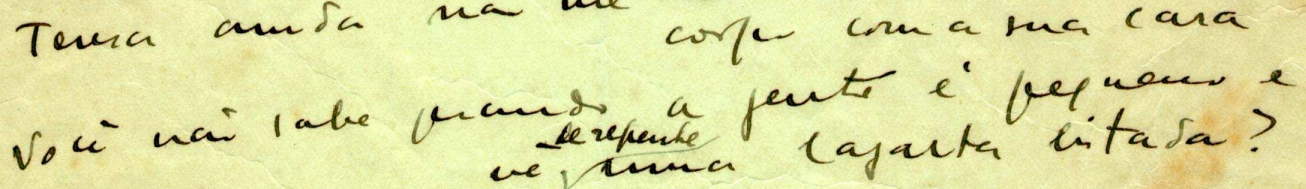

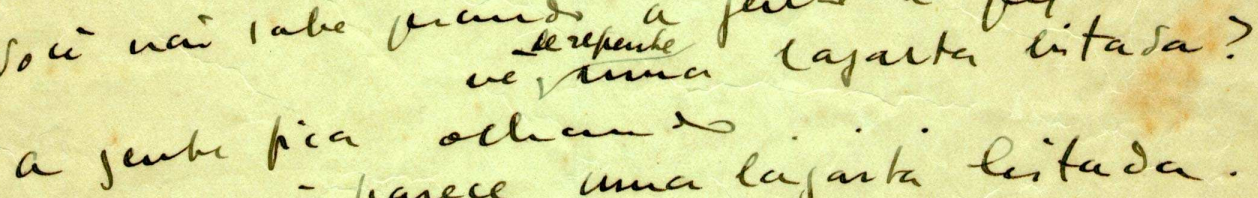
Terna voci farece una lajarta bitada.

Tena wa éenpracara vocé frarece lonca!

108 


\section{MA - MOE, 75}

BANDEIRA, Manuel (Manuel Carneiro de Sousa Bandeira Filho 1886-1968)

75. Vou-me embora pra Pasárgada ou Rondó do Aporrinhado; poesia (MAd)

[Rio de janeiro, post. 3 set. 1927]

Autógrafo a tinta preta; papel branco; 2 folhas; 27,6 x 21,3 cm; vincos; sinais de fungo; escrita no anverso; fólios numerados pela pesquisa: (1)-(2).

Notas da pesquisa:

1. Ms na vertente Mário de Andrade no diálogo interpares.

2. Data e local atestados com base na carta de MB a MA, Rio de Janeiro, 3 de setembro de 1927, na qual comenta a criação do poema Vou-me embora pra Pasárgada: "Ando com uns projetos de redondilha para um poema aporrinhado cujo estribilho é 'Vou-me embora pra Pasárgada' mas não tomou jeito de sair até hoje. Pasárgada é uma antiga cidade persa, você naturalmente sabe. Claro que não é vontade de ir pra Pérsia. Pasárgada é a coisa estapafúrdia pra onde um aporrinhado sente gana de ir" (Correspondência Mário de Andrade \& Manuel Bandeira. Ed. cit., p. 353).

3. MA, em 4 de outubro de 1927: "Vou-me embora pra Pasárgada' carece sair como refrão dum poema, seja em redondilha, seja livre. Que venha quando puder" (Correspondência Mário de Andrade \& Manuel Bandeira. Ed. cit., p. 356).

4. "Vou-me embora pra Pasárgada" foi publicado em Libertinagem (ed. cit.).

5. Há dois exemplares de Libertinagem na biblioteca MA. O primeiro traz Notas MA a lápis selecionando poemas; o segundo, com as folhas dos cadernos não separadas pela espátula de MA, guarda na folha de ante-rosto a dedicatória: "Ao querido Mario, | of. | Manuel | 1930". Assim acontece porque MA bibliófilo costumava guradar intactos os exemplarescom dedicatória, adquirindo ou reavendo um segundo exemplar no qual exercia sua leitura de crítico, anotando a lápis. Quando souberam disso, vários autores passaram a lhe oferecer dois exemplares das obras.

6. Em 22 de junho de 1930 o Diário Nacional publicou a crônica de MA "Puro, sem mistura", que focaliza Libertinagem ao lado de Alguma poesia de Carlos Drummond de Andrade.

Estudo genético:

1. O ms apresenta-se em uma única versão, A, que mostra 1 etapa na escritura.

2. Versão A confrontada com a versão B em Libertinagem (ed. cit.), mostra poucas variantes. O confronto feito por Telê Ancona Lopez está na coletânea por ela coordenada: Manuel Bandeira: verso e reverso. São Paulo, TA Queiroz/FAPESP, 1987, p. 151-155. 


\section{MA - MOE, 76}

BANDEIRA, Manuel (Manuel Carneiro de Sousa Bandeira Filho 1886-1968)

76. Dindinha-lua; poesia (MAd)

[Rio de Janeiro, ant. 11 jul. 1928]

Autógrafo a tinta preta; papel tipo jornal; 1 folha; 25,5/25,7 x 18,2/18,4 cm; borda superior picotada com rasgamentos; rasgamento no canto inferior à esquerda; vincos; sinais de fungo; escrita no anverso; assinatura: “ㅆ..", fólio numerado pela pesquisa: (1).

Notas da pesquisa:

1. Ms na vertente Mário de Andrade no diálogo interpares.

2. Data atestada com base na carta de MA a MB, São Paulo, 11 de julho de 1928, pela qual se compreende que o ms já se achava nas mãos do escritor paulista: "estava pra escrever pra você dizendo que o poeminha da 'Dindinha Lua' vale ouro. Agora ontem saiu a carta de você pra Antropófaga e isso espertou inda mais a vontade. 'Dindinha Lua' vale ouro e ri uma dia inteiro. Você nas suas safadezas às vezes é tão humano que até vinga os outros. Dentro da sensibilidade doce do poeminha tem uma sátira danada pros que estão reduzindo a pó-de-traque tanta trabalhadeira séria e elevada, sobretudo a minha neste caso particular. Me senti bem vingado da Lua estar mandando à p... ..., os que estão abusando e ridicularizando uma coisa que pra mim é tão séria. Por isso o poema valeu inda mais que se valesse só pela poesia dele que já é enorme". (Correspondência Mário de Andrade \& Manuel Bandeira, ed. cit., p. 395)

3. Dindinha-lua recebeu publicação póstuma em LOPEZ, Telê Ancona, org. Manuel Bandeira: verso e reverso. São Paulo, T. A. Queiroz, 1987, p. 172-174.

Estudo genético:

1. O ms apresenta-se em uma única versão, A, que mostra 1 etapa na escritura.

\section{MA - MOE, 77}

BANDEIRA, Manuel (Manuel Carneiro de Sousa Bandeira Filho 1886-1968)

77. Namorados; poesia (MAd)

[Rio de Janeiro, ant. 29 jul. 1928]

Autógrafo a tinta preta; papel branco; 1 folha; 27,0 x 21,3 cm; vincos; sinais de fungo; escrita no anverso; assinatura: "MB"; fólio numerado pela pesquisa: (1).

Notas da pesquisa:

1. Ms na vertente Mário de Andrade no diálogo interpares.

2. Data e local atestados com base na carta de MA a MB, de São Paulo, 29 jul. 1928, na qual o remetente acusa o seu recebimento do ms: "escrevo só por causa dos 'Namorados' sobre o qual você pede opinião. [...] 'Namorados' está baita. Mas é outro poema. Ficam dois poemas um formidável inédito enquanto não possa ser publicado e outro que vai ser conhecido e gostado. É ótimo e é das coisas mais Manuel-Bandeira 
deste mundo." (Correspondência Mário de Andrade \& Manuel Bandeira. Ed. cit., p. 398)

3. Versão anterior de Namorados foi enviada a MA com o título Lagarta listada (V. MA MOE, 74).

4. Namorados está em Libertinagem (Rio de Janeiro, ed. cit.).

5. Há dois exemplares de Libertinagem na biblioteca MA. O primeiro traz Notas MA a lápis selecionando poemas; o segundo, com as folhas dos cadernos não separadas pela espátula de MA, guarda na folha de ante-rosto a dedicatória: "Ao querido Mario, | of. | Manuel | 1930". Assim acontece porque MA bibliófilo costumava guradar intactos os exemplarescom dedicatória, adquirindo ou reavendo um segundo exemplar no qual exercia sua leitura de crítico, anotando a lápis. Quando souberam disso, vários autores passaram a lhe oferecer dois exemplares das obras.

6. Em 22 de junho de 1930 o Diário Nacional publicou a crônica de MA "Puro, sem mistura", que focaliza Libertinagem ao lado de Alguma poesia de Carlos Drummond de Andrade.

Estudo genético:

1. O ms apresenta-se na versão B e mostra 1 etapa na escritura. A análise documentária da versão A, quando o texto tem o título de Lagarta listada, está neste catálogo: MAMOE, 73.

2. A versão B foi confrontada com a versão C, em Libertinagem, ed. cit. Há variantes.

3. O confronto feito por Telê Ancona Lopez está na coletânea por ela coordenada: Manuel Bandeira: verso e reverso. São Paulo, TA Queiroz/FAPESP, 1987, p. 142-150.

\section{MA-MOE, 78}

BANDEIRA, Manuel (Manuel Carneiro de Sousa Bandeira Filho 1886-1968)

78. [P] urificar-se; tradução (MAd)

[Rio de Janeiro ou Petrópolis ?], 1929

Datiloscrito, cópia carbono preto; papel branco; 1 folha; 27,3/27,6 x 21,7 cm; rasgamentos na borda direita; vincos; sinais de fungo; escrita no anverso; fólio numerado pela pesquisa: (1). Nota MB a tinta preta: "Pedro Leandro Ypuche Tradução de |Manuel Bandeira". Nota T a lápis preto no verso: "2209 | H. fazer".

Nota MA a lápis preto: “Rumbo Desnudo’ |A. Monteverde e Cia 1928 | Uruguai | 1929”.

Notas da pesquisa:

1. Ms na vertente Mário de Andrade no diálogo interpares.

2. Pedro Leandro Ypuche (1889-1976) foi poeta e contista uruguaio; teve publicado os livros: Engarces, Alas nuevas, Tierra honda, Júbilo y miedo.

Estudo genético:

1. O ms apresenta-se em uma única versão, A, que mostra 1 etapa na escritura. 


$$
\text { NAMORATPOS }
$$

- vapar chepon-re para punto da unca e Jisine:

- Autoria, arirda nó corsejir me habituar com o sea corfe, crm a jua cara.

A moca othor de lado e esperon.

- Vocé viá sabe juando a gente écrianca e de repente ve una lagasta listrada?

A noca de lembrava:

- A gente fiea vthando...

A meninice brincern de movo nor othen dela. - rapar prossegrim, coren muita docerra:

- Antoria, vocé parece una lagarta bitrada. A inoca arregalou or othen, fer relamacón.

Orapar concluin:

- Antovia, vócé è engracata! Vocé parece lonca.

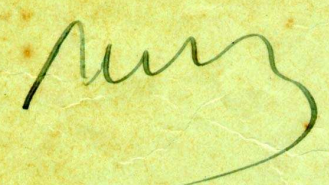

112 


\section{MA-MOE, 79}

BANDEIRA, Manuel (Manuel Carneiro de Sousa Bandeira Filho 1886-1968)

79. A Virgem Maria; poesia (MAd)

[Rio de Janeiro, ant. 1930]

Autógrafo a tinta preta; papel branco, filigrana; 1 folha; 28,0/28,2 x 21,4 cm; vincos; sinais de fungo; escrita no anverso; fólio numerado pela pesquisa: (1).

Notas da pesquisa:

1. Ms na vertente Mário de Andrade no diálogo interpares.

2. Data atestada com base na data em que o poema no ms foi publicado: Libertinagem (ed. cit.).

3. Há dois exemplares de Libertinagem na biblioteca MA. O primeiro traz Notas MA a lápis selecionando poemas; o segundo, com as folhas dos cadernos não separadas pela espátula de MA, guarda na folha de ante-rosto a dedicatória: "Ao querido Mario, | of. | Manuel | 1930". Assim acontece porque MA bibliófilo costumava guradar intactos os exemplarescom dedicatória, adquirindo ou reavendo um segundo exemplar no qual exercia sua leitura de crítico, anotando a lápis. Quando souberam disso, vários autores passaram a lhe oferecer dois exemplares das obras.

4. Em 22 de junho de 1930 o Diário Nacional publicou a crônica de MA "Puro, sem mistura", que focaliza Libertinagem ao lado de Alguma poesia de Carlos Drummond de Andrade.

Estudo genético:

1. O ms apresenta-se em uma única versão, A, que mostra 1 etapa na escritura.

2. Versão A confrontada com a versão B em Libertinagem, mostra variantes.

\section{MA-MOE, 80}

BANDEIRA, Manuel (Manuel Carneiro de Sousa Bandeira Filho 1886-1968)

80. Oração a Terezinha do menino Jesus; poesia (MAd)

[Rio de Janeiro, ant. 1930]

Autógrafo a tinta preta; papel branco, filigrana; 2 folhas; 28,0/28,2 x 21,4 cm; vincos; sinais de fungo; escrita no anverso; f. 2: assinatura: "Manuel Bandeira"; fólios numerados pela pesquisa: (1)-(2).

Notas da pesquisa:

1. Ms na vertente Mário de Andrade no diálogo interpares.

2. Data atestada com base na data em que o poema no $\mathrm{ms}$ foi publicado em Libertinagem (ed. cit.).

3. Há dois exemplares de Libertinagem na biblioteca MA. O primeiro traz Notas MA a lápis selecionando poemas; o segundo, com as folhas dos cadernos não separadas pela espátula de MA, guarda na folha de ante-rosto a dedicatória: "Ao querido Mario, | of. | Manuel | 1930”. Assim acontece porque MA bibliófilo costumava guradar intactos os 
exemplarescom dedicatória, adquirindo ou reavendo um segundo exemplar no qual exercia sua leitura de crítico, anotando a lápis. Quando souberam disso, vários autores passaram a lhe oferecer dois exemplares das obras.

4. Em 22 de junho de 1930 o Diário Nacional publicou a crônica de MA "Puro, sem mistura", que focaliza Libertinagem ao lado de Alguma poesia de Carlos Drummond de Andrade.

Estudo genético:

1. O ms apresenta-se em uma única versão, A, que mostra 1 etapa na escritura.

2. Versão A confrontada com a versão B em Libertinagem (ed. cit.), mostra variantes.

\section{MA-MOE, 81}

BANDEIRA, Manuel (Manuel Carneiro de Sousa Bandeira Filho 1886-1968)

81. Estrela da Manhã; poesia (MAd)

[Rio de Janeiro, ant. 26 jul. 1930]

Datiloscrito, cópia carbono preto; papel branco; 1 folha; 27,5 x 21,6 cm; vincos; sinais de fungo; escrita no anverso; assinatura a máquina: "Manuel Bandeira."; fólio numerado pela pesquisa: (1).

Notas da pesquisa:

1. Ms na vertente Mário de Andrade no diálogo interpares.

2. Data e local atestados com base na carta de MB a MA, do Rio de Janeiro,b em 26 de julho de 1930, se lê: "O poema 'Estrela da Manhã' sairá nas Novidades Literárias do Schmidt com ilustração do Cícero. Fiz leves alterações. Em vez de 'Procurem nos mictórios nas latas de lixo...' | pus | 'Procurem nos becos nos cais, nos boeiros da City...' | Suprimi o senador gagá. E mais adiante: | '... comerei terra e direi coisas de uma ternura tão nova | Que tu desfalecerás! | Procurem por toda parte E o final". (Correspondência Mário de Andrade \& Manuel Bandeira, ed. cit., p. 454). No arquivo MA encontram-se as duas versões mencionadas por MB nesta carta.

3. Poema publicado em Estrela da Manhã (Rio de Janeiro, Editora do Autor, 1936).

4. Há dois exemplares de Estrela da Manhã na biblioteca de MA: um deles com os cadernos não abertos pela espátula do presenteado e a dedicatória: "A Mario, | com a velha amizade | Manuel | 1937". O outro exemplar tem um cartão de visita de MB com a dedicatória: "ex. do / Mario". Assim acontece porque MA bibliófilo costumava guradar intactos os exemplarescom dedicatória, adquirindo ou reavendo um segundo exemplar no qual exercia sua leitura de crítico, anotando a lápis. Quando souberam disso, vários autores passaram a lhe oferecer dois exemplares das obras.

\section{Estudo genético:}

1. Estrela da Manhã apresenta-se em 2 versões. A acima registrada foi considerada versão A pois não possui ainda as substituições mencionadas por MB na carta de 26 de julho de 1930 (v. nota da pesquisa: 2). A versão B, com as substituições mencionadas na carta, está neste catálogo: MA-MOE, 82.

2. Versão mostra 1 etapa na escritura. 
3. Versão A confrontada com a versão B, no ms, e com a versão C em Estrela da Manhã (ed. cit.). Há variantes nas três versões.

\section{MA-MOE, 82}

BANDEIRA, Manuel (Manuel Carneiro de Sousa Bandeira Filho 1886-1968)

82. Estrela da Manhã; poesia (MAd)

[Rio de Janeiro, ant. 26 jul. 1930]

Datiloscrito, cópia carbono preto; papel branco; 1 folha; 27,5 x 21,6 cm; rasgamentos na borda direita; vincos; sinais de fungo; manchas de carbono; escrita no anverso; assinatura a máquina: "Manuel Bandeira"; fólio numerado pela pesquisa: (1).

\section{Notas da pesquisa:}

1. Ms na vertente Mário de Andrade no diálogo interpares.

2. Data e local atestados com base na carta de MB a MA, do Rio de Janeiro em 26 de julho de 1930 (V. MA-MOE, 81, nota 2).

3. Poema publicado em Estrela da Manhã (ed. cit.).

4. Há dois exemplares de Estrela da Manhã na biblioteca de MA: um deles com os cadernos não abertos pela espátula do presenteado e a dedicatória: "A Mario, | com a velha amizade | Manuel | 1937". O outro exemplar tem um cartão de visita de MB com a dedicatória: "ex. do / Mario". Assim acontece porque MA bibliófilo costumava guradar intactos os exemplarescom dedicatória, adquirindo ou reavendo um segundo exemplar no qual exercia sua leitura de crítico, anotando a lápis. Quando souberam disso, vários autores passaram a lhe oferecer dois exemplares das obras.

Estudo genético:

1. Estrela da Manhã apresenta-se em 2 versões. A acima registrada foi considerada versão B. V. análise documentária da versão A em MA-MOE, 81.

2. Versão B confrontada com a versão A, no ms, e com a versão C em Estrela da Manhã (ed. cit.). Há variantes entre as três versões.

\section{MA-MOE, 83}

BANDEIRA, Manuel (Manuel Carneiro de Sousa Bandeira Filho 1886-1968)

83. Oração a Nossa Senhora da Boa Morte; poesia (MAd)

[Rio de Janeiro, ant. 1936]

Datiloscrito, cópia carbono preto; papel branco; 1 folha; 27,5 x 21,6 cm; canto inferior direito e borda esquerda: amassados; vincos; sinais de fungo; manchas de carbono; escrita no anveso; assinatura a máquina: "Manuel Bandeira."; rasuras a tinta preta; fólio numerado pela pesquisa: (1). 
Notas da pesquisa:

1. Ms na vertente Mário de Andrade no diálogo interpares.

2. Data atestada com base na data em que o poema no ms foi publicado: Estrela da Manhã (ed. cit.)

3. Há dois exemplares de Estrela da Manhã na biblioteca de MA: um deles com os cadernos não abertos pela espátula do presenteado e a dedicatória: "A Mario, | com a velha amizade | Manuel | 1937". O outro exemplar tem um cartão de visita de MB com a dedicatória: "ex. do / Mario". Assim acontece porque MA bibliófilo costumava guradar intactos os exemplarescom dedicatória, adquirindo ou reavendo um segundo exemplar no qual exercia sua leitura de crítico, anotando a lápis. Quando souberam disso, vários autores passaram a lhe oferecer dois exemplares das obras.

Estudo genético:

1. O ms apresenta-se em uma única versão, $A$, que mostra 2 etapas na escritura: $a-a_{1}$ : a: datiloscrito; $\mathrm{a}_{1}$ : rasuras a tinta preta.

2. Versão A confrontada com a versão B, em Estrela da Manhã, (ed. cit.), mostra variantes.

\section{MA-MOE, 84}

BANDEIRA, Manuel (Manuel Carneiro de Sousa Bandeira Filho 1886-1968)

84. “'O sr. Gustavo Barroso é uma inteligência voltada”; verbete (MAd)

[Rio de Janeiro ou Petrópolis?] s/ data

Autógrafo a tinta preta; papel branco; 1 folha; 26,2 x 20,5/20,6 cm; rasgamento na borda direita inferior; vincos; sinais de fungo; escrita no anverso e no verso; rasura a tinta preta; fólio numerado pela pesquisa: (1). Nota MB no final do texto: "(da 'Revista Imaginária)".

Notas da pesquisa:

1. Ms na vertente Mário de Andrade no diálogo interpares.

2. Em carta de MB a MA, do Rio de Janeiro, em 2 de abril de [1925], há uma referência a Gustavo Barroso Dodt, na época diretor da revista Fon-fon.

Estudo genético:

1. O ms apresenta-se em uma única versão, $A$, que mostra 2 etapas na escritura: $a-a_{1}$ : a: autógrafo completo; $\mathrm{a}_{1}$ : rasura a tinta preta. 


\section{MA-MOE, 85}

BANDEIRA, Manuel (Manuel Carneiro de Sousa Bandeira Filho 1886-1968)

85. O mangue; ensaio (MAd)

[Rio de Janeiro ou Petrópolis?], s/ data

Datiloscrito, cópia caborno preto: f. 1-3, caborno azul: f. 2; papel branco, filigrana: "Chanceller"; 3 folhas; 28,0 x 21,6 cm: f. 1, 28,1 x 22,0 cm: f. 2-3; f. 2: rasgamentos nas bordas direita e esquerda e nos cantos direito: inferior e superior; fólio 3: rasgamentos na borda direita; vinco; f. 1-2: sinais de fungo; manchas de carbono; folhas numeradas pelo escritor: $2-3$; escrita no anverso; f. 1: assinatura a máquina em baixo do título: "Manuel Bandeira"; rasuras a máquina; fólios numerados pela pesquisa: (1)-(3).

\section{Notas da pesquisa:}

1. Ms na vertente Mário de Andrade no diálogo interpares.

2. O texto no ms foi publicado em: SEGALL, Lasar. Mangue. Texto de Jorge de Lima, Mário de Andrade, Manuel Bandeira. Rio de Janeiro, Philobiblion, 1977. Mário de Andrade guardou dois exemplares do livro em sua biblioteca.

\section{Estudo genético:}

1. O ms apresenta-se em uma única versão $A$, que mostra 2 etapas na escritura: $a-a_{1}$ : a: datiloscrito completo; $\mathrm{a}_{1}$ : rasura a máquina.

2. Versão A confrontada com a versão B em Mangue (ed. cit.), exibe poucas variantes.

\section{MA-MOE, 86}

\section{BATINI, Tito}

86. - E agora, que fazer?; romance (MAc)

[São Paulo], maio 1938 - set. 1939

Datiloscrito: cópia carbono preto e azul, e original fita vermelha; papel branco, verde, rosa; f. 1: capa improvisada em pasta cinza recortada com pedaço de cartolina beje colada no verso; 330 folhas; as medidas das folhas variam entre 12,5/15,5 x 21,9 cm e $32,5 \times 22,0 \mathrm{~cm}$; furos para arquivamento; bordas amassadas; tiras de papel beje coladas no anverso com números a lápis indicando os capítulos, no verso para unir folhas recortadas; escrita no anverso; folhas numeradas pelo escritor a lápis preto e a máquina; rasuras a máquina, a lápis tinta, a lápis preto, a lápis vermelho e a lápis azul; fólios numerados pela pesquisa: (1)-(3) (3) (0). Notas TB a lápis preto: f. 1: título e data do início e do término na redação do ms: “- E agora, | que fazer? | Maio 1938 | Setembro 1939"; f. 2: "paginar os capitu- | los seguidamente | capa em cartolina | tinta forte | envernizar a capa". 
Notas da pesquisa:

1. Ms na vertente Mário de Andrade colecionador.

2. Na série Correspondência Mário de Andrade, no IEB-USP, não há carta que comprove o envio do ms.

3. Romance publicado em 1941: - E agora, que fazer? (Rio de Janeiro/ São Paulo, Editora Civilização Brasileira, 1941)

4. Sobre o livro - E agora, que fazer?, MA publicou o artigo "Tito Batini”" em sua seção "Vida literária" no Diário de Notícias, do Rio de Janeiro em 18 de junho de 1942. Texto publicado em Vida Literária. Pesquisa, estabelecimento de texto, introdução e notas de Sonia Sachs, São Paulo, HUCITEC, 1993, p. 247-250.

Estudo genético:

1. O ms apresenta-se em uma única versão, A, que mostra diferentes etapas na escritura a serem tratadas de forma detida em trabalho específico.

\section{MA - MOE, 87}

BOPP, Raul (1898-1984)

87. Caratatêua; poesia (MAd)

[Rio de Janeiro ?, ant. 1932]

Autógrafo a tinta preta; papel branco, filigrana; 1 folha; $34,0 \times 22,4 / 22,5 \mathrm{~cm}$; bordas irregulares; sinais de fungo; vincos; escrita no anverso; visto do escritor na margem inferior; fólio numerado pela pesquisa: (1).

Nota MA a lápis preto: verso: "Raul Bopp".

Notas da pesquisa:

1. Ms na vertente Mário de Andrade no diálogo interpares.

2. Caratatêua foi publicado pela primeira vez no Almanaque Globo, n. 11, Porto Alegre, 1927, e integra Urucungo (Rio de Janeiro, Ariel Editora Ltda. [1932]). Data atestada com base no ano de publicação do livro.

3. MA preservou em sua biblioteca um exemplar de Urucungo, no qual deixou notas de leitura a lápis preto.

4. Na edição Poesia completa (Rio de Janeiro/ São Paulo, José Olympio/ Edusp, 1998), o organizador Augusto Massi elucida alguns pontos sobre a elaboração de Urucungo: "Cobra Norato e Urucungo foram escritos graças à farta coleta de materiais realizada durante sua permanência no Norte e no Nordeste. [...] Urucungo incorporou uma ampla gama de ritmos e expressões afro-brasileiras devido a sua passagem pelo Recife, onde conviveu com José Lins do Rego e Luís da Câmara Cascudo" (p. 15); "Urucungo foi publicado em 1932, com capa de Santa Rosa, por força dos amigos Luiz Vergara, Manlio Giudice, Jorge Amado, Danton Coelho e Carlos Echenique. Nunca mais foi reeditado na íntegra. Ao longo dos anos, sucessivas antologias desfiguraram a estrutura original da obra, na qual a questão dos negros, pela primeira vez, adotava uma perspectiva histórica radical. Urucungo começa com Pai-João recordando o Congo e termina com registros quase fotográficos do negro "livre" vivendo nas favelas." (p. 221). 
Estudo genético:

1. O ms apresenta-se em uma única versão, A, que mostra 1 etapa na escritura.

2. Versão A confrontada com a versão B Urucungo (ed. cit.) mostra variantes.

\section{MA - MOE, 88}

BOPP, Raul (1898-1984)

88. Cidade selvagem; Mãe febre; Marabaxo (Dansa de negro); Milu; Negro; Pae-João; poesia (MAd)

[Rio de Janeiro ?, ant. 1932]

Datiloscrito original, fita azul, fita vermelha: f. 1; títulos em autógrafo a tinta preta; pepel beje; 6 folhas; 32,9 x 22,2 cm; rasgamentos na borda direita; rasgamentos na borda inferior; sinais de fungo; vinco; escrita no anverso; rasuras a máquina, a tinta preta e a lápis preto; visto do escritor a tinta preta na margem inferior; fólios numerados pela pesquisa: (1)-(6).

Nota MA a lápis preto: verso da f. 2: "Raul Bopp".

Notas da pesquisa:

1. Ms na vertente Mário de Andrade no diálogo interpares.

2. Marabaxo, Negro e Pae-João foram publicados em Urucungo (ed. cit.), 1932. Data atestada com base no ano de publicação do livro.

3. Milu, Cidade selvagem e Mãe febre permaneceram inéditos até a edição póstuma: BOPP, Raul. Poesia completa. Augusto Massi (org.). Rio de Janeiro/ São Paulo, José Olympio/ Edusp, 1998)

4. MA preservou em sua biblioteca um exemplar de Urucungo, no qual deixou notas a lápis preto.

Estudo genético:

1. O ms apresenta-se em uma única versão, A.

2. Cidade selvagem mostra 4 etapas na escritura: $\mathrm{a}-\mathrm{a}_{1}-\mathrm{a}_{2}-\mathrm{a}_{3}$ :

a: datiloscrito e fita azul;

$\mathrm{a}_{1}$ : datiloscrito em fita vermelha;

$\mathrm{a}_{2}-\mathrm{a}_{3}$ : rasuras a tinta preta e a lápis preto, sem possibilidade de se identificar a ordem dessas etapas.

3. Mãe febre, Marabaxo (Dansa de negro), Milu; Negro e Pae-João mostram 2 etapas na escritura: $\mathrm{a}-\mathrm{a}_{1}$ :

a: datiloscrito completo;

$\mathrm{a}_{1}$ : rasuras e notas a tinta preta.

4. A versão A dos poemas Marabaxo, Negro e Pae-João foi confrontada com a versão B Urucungo (ed. cit.). Há variantes. 


\section{MA - MOE, 89}

\section{BRISOLA, Ciro (Cyro Monteiro Brisolla)}

89. A volta do filho pródigo; "Como é longa a viagem a áspero o caminho,"; Canto da trigésima desesperação; Noturno das correntes da vida; $O$ negro no espaço; Rondó sôbre um tema de Sérgio Milliet; Seresta I; Seresta II; Seresta III; "Abrir as portas azuis do pensamento"; "Não fujo dessa voz que envolve todo o mar"; poesia (MAm) [São Paulo], s/ data

Datiloscrito original, fita preta: f. 1-10; datiloscrito, cópia carbono preto: f. 11; papel branco; 1 folha; f. 1-2: 32,6 x 21,9, f. 3-5: 32,7 x 22,7 cm, com variações em mm; f. 7: vinco no canto superior esquerdo; manchas de acidez; escrita no anverso; rasuras a tinta a preta e a máquina; fólios numerados pela pesquisa: (1)-(1) (1). Notas MA.

A volta do filho pródigo:

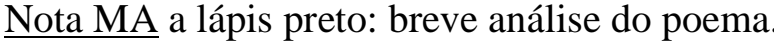

"Como é longa a viagem a áspero o caminho,":

Notas MA: a lápis preto: breve análise do poema e correções a tinta preta: "não revisto".

Canto da trigésima desesperação:

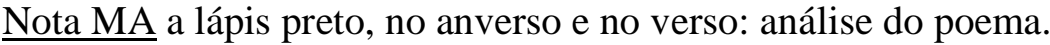

Noturno das correntes da vida:

Nota MA a lápis preto: breve análise do poema.

O negro no espaço:

Notas MA a lápis preto: sugestão de substituição e breve análise do poema.

Rondó sôbre um tema de Sérgio Milliet:

Notas MA a lápis preto: sugestões de substituição, correções, anotação na margem esquerda: "Ciro gosta" e comentário ao poema.

Seresta I:

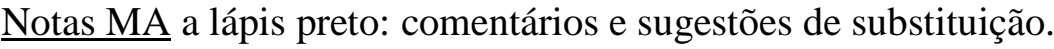

Seresta II:

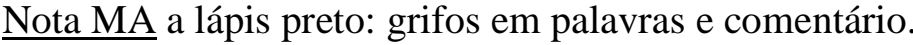

\section{Seresta III}

Nota MA a lápis preto: breve análise do poema e anotação na margem esquerda: "Ciro gosta”.

"Abrir as portas azuis do pensamento":

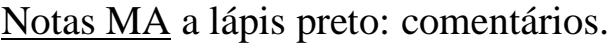


"Não fujo dessa voz que envolve todo o mar":

Notas MA a lápis preto: sugestões de substituição e breve análise do poema.

Notas da pesquisa

1. Ms na vertente Mário de Andrade mentor.

2. Na série Correspondência de Mário de Andrade, no IEB-USP, existe uma única carta de CB a MA, datada de Sãso Paulo, 2 de junho de 1940 sem menção do envio dos poemas.

3. MA dedicou a CB o ensaio "Atualidade de Chopin" que faz parte da coletânea ANDRADE, Mário. O baile das quatro artes. São Paulo, Livraria Martins, 1963.

\section{Estudo genético:}

1. O ms apresenta-se em uma única versão, A, que mostra nos poemas Canto da trigésima desesperação, O negro no espaço, Seresta III, "Não fujo dessa voz que envolve todo o mar" 1 etapa na escritura, e nos poemas A volta do filho pródigo, "Como é longa a viagem a áspero o caminho,", Noturno das correntes da vida, Rondó sôbre um tema de Sérgio Milliet, Seresta I, Seresta II, "Abrir as portas azuis do pensamento" 2 etapas na escritura: $a-a_{1}$ :

a: datilografado completo;

$\mathrm{a}_{1}$ : rasuras a tinta preta.

\section{MA - MOE, 90}

BRITO, Mário da Silva (1916-)

90. Louvação de um polígrafo paulista; crítica (MAc)

[São Paulo, ant. 27 abr 1943]

Datiloscrito original, fitas preta e vermelha; papel branco, filigrana: "Royal Typsi Industria Brasileira"; 3 folhas; 27,6 x 21,8 cm; vincos; f. 3: sinais de fungo; furo de grampo na margem superior; f. 1: ferrugem de grampo na margem inferior; escrita no anverso; folhas numeradas pelo escritor: 2-3; f. 1: assinatura a máquina: "Mário da Silva Brito."; rasuras a máquina e a tinta azul; fólios numerados pela pesquisa: (1)-(3).

Notas da pesquisa:

1. O ms enquadra-se na vertente Mário de Andrade colecionador.

2. MSB enviou o ms a MA junto da carta de São Paulo, 27 de abril de 1943, na qual esclarece o envio do ms: sanar erros ocorridos na publicação em revista cujo título não declina (Ref.: série Correspondência Mário de Andrade - sub-série Correspondência passiva, MA-C-CPL, $\mathrm{n}^{\circ} 1512$ ).

3. Pela carta de 17 de março de 1944, sabe-se que MSB remeteu a MA 3 "rimances", com o pedido de opinião. Esse ms não se acha atualmente no Arquivo MA. (Ref.: série Correspondência Mário de Andrade - sub-série Correspondência passiva, MA-C-CPL, $n^{\circ} 1513$ ) 
Estudo genético:

1. O ms apresenta-se em uma única versão, A, que mostra 2 etapas na escritura: a-a $a_{1}$ : a: datiloscrito completo;

$\mathrm{a}_{1}$ : rasuras a tinta azul.

MA - MOE, 91

CAMPELO, Samuel (Samuel Carneiro Rodrigues Campelo 1889-1939)

91. Pastoril de minha terra; poesia (MAm)

Recife, [ant. 1939]

Datiloscrito original, fita preta; papel branco; 3 folhas; $32,7 \times 21,9 / 22,0 \mathrm{~cm}$; f. 3 : rasgamento na borda direita; vincos; sinais de fungo; escrita no anverso; folhas numeradas pelo escritor: $2-3$; f. 3 : assinatura a tinta preta, local e assinatura a máquina: "Recife. | Samuel Campêlo.”; rasuras a máquina e a tinta preta; fólios numerados pela pesquisa: (1)-(3).

Notas de pesquisa:

1. Ms na vertente Mário de Andrade mentor.

2. Data atestada com base no ano da morte do escritor.

3. Nas cartas SC a MA, na série Correspondência Mário de Andrade, no IEB-USP, há menção ao envio de textos de crítica e de teatro, mas nada sobre o poema no ms.

Estudo genético:

1. O ms apresenta-se em única versão, $A$, que mostra 3 etapas na escritura: $a-a_{1}-a_{2}$ : a: datiloscrito completo;

$\mathrm{a}_{1}$ : rasuras a máquina;

$\mathrm{a}_{2}$ : rasura a tinta preta.

MA - MOE, 92

CAMPOS, Eduardo (Manuel Eduardo Pinheiro Campos 1923-?)

92. No Morro do Moinho morre um menino...; conto (MAm)

Fortaleza, 20 set. 1943

Datiloscrito, cópia carbono roxo; papel rosa; 3 folhas; 27,2/ 27,3 x 20,5 cm; vincos; sinais de fungo; f. 2: 2 furos pequenos; f. 2-3: manchas de carbono; escrita no anverso; f. 1: dedicatórias: "A MÁRIO DE ANDRADE" e "A Mario de Andrade", quase apagada, f. 3: local, data e assinatura a tinta azul ilegível: "Fortaleza, 20/9/43"; rasuras: f. 1-2: a máquina, f. 2: a tinta azul.

Notas MA: a lápis vermelho: f. 1: grifo na oração "que se lhe escapava"; a lápis azul: numeração das folhas: I-III. 
Notas da pesquisa:

1. Ms na vertente Mário de Andrade mentor.

2. No morro do moinho morre um menino... permaneceu inédito.

3. Na carta datada de Fortaleza, 27 de setembro de 1943, EC menciona ter enviado a MA o ms de um conto cujo título não acusa mas que é, provavelmente, o ms acima registrado: "Sei que você continúa doente. | Não vou exigir que me responda, com brevidade. Quando se julgar | completamente bom, cousa que não custará, poderá dizer sua opi | nião a respeito desse conto que segue anexo para você". (Ref.: série Correspondência Mário de Andrade - sub-série Correspondência passiva; MA-C-CPL, $\left.\mathrm{n}^{\circ} 1597\right)$

Estudo genético:

1. O ms apresenta-se em uma única versão, $A$, que mostra 3 etapas na escritura: $a-a_{1}-a_{2}$ :

a: datiloscrito completo;

$\mathrm{a}_{1}$ : rasuras a máquina;

$\mathrm{a}_{2}$ : rasura a tinta azul.

\section{MA - MOE, 93}

CARDOSO, Lúcio (Joaquim Lúcio Cardoso Filho 1913-1968)

93. A luz no sub-solo; romance (MAc)

[Rio de Janeiro, post. 1936]

Autógrafo a lápis preto, a tinta azul, a tinta preta e a lápis tinta; datiloscrito original, fita preta; papel branco, pautado: f. 1-66, 70-75, 81-82, 84-146, filigrana; 146 folhas; $\mathrm{f}$. 1-81, 83-146: 33 x $22 \mathrm{~cm}$, com variações em mm; f. 82: 19,6/ 20,2 x 14,5 cm; bordas irregulares, amassadas e com rasgamentos; borda esquerda recortada; f. 2: bordas superior e inferior recortadas; f. 106: rasgamento na parte inferior da folha; f. 110,111: rasgamento na borda superior; vincos; sinais de fungo; f. 50, 77: mancha de tinta azul; f. 1, 23, 39, 67-69, 75-83, 91, 93, 105-106: escrita no anverso; f. 2-22, 24-38, 40-66, 70-74, 84-90, 92, 94-104, 107-146: escrita no anverso e no verso; f. 18, 28: desenhos a lápis preto no verso; f. 1: folha de rosto com autoria, título e assinaturas: "Lucio Cardoso | A luz no | sub-solo", "JLuna"; f. 69 assinatura e título em autógrafo a tinta preta: "(A LUZ NO | SUB-SOLO)", "Lucio Cardoso"; rasuras a lápis preto, a tinta azul, a lápis azul, a máquina e a tinta preta. Notas LC a lápis preto: f. 40, 50, 66 no verso, 76, 90, 105: lembretes para reorganizar a distribuição do texto e observações a respeito da narrativa, 91-92: sinal de X, a tinta azul: f. 89 no verso: "parar aqui".

Notas da pesquisa:

1. O ms enquadra-se na vertente Mário de Andrade colecionador.

2. O ms não apresenta o capítulo I.

3. Data atestada com base no ano da edição de $A$ luz no sub-solo pela Livraria José Olimpio Editora (Rio de Janeiro, 1936). O ms mostra o trabalho do escritor na elaboração do romance, sem passar a limpo para ser lido por MA. Antes da publicação, foi oferecido a ele para a salvaguarda por isso não se configura a vertente Mário de Andrade mentor. 
4. Há dois exemplares do livro de LC na biblioteca MA: um deles com as folhas fechadas e a dedicatória: "Ao| Mario de Andrade, | com a admiração do | Lucio Cardoso.”; o outro em duplicata sem dedicatória nem anotações de MA.

Estudo genético:

1. O ms apresenta-se em uma única versão, A, que mostra diferentes etapas na escritura a serem tratadas de forma detida em trabalho específico.

\section{MA - MOE, 94}

\section{CARNEIRO, Cecílio José (1911-1970)}

94. A fogueira; romance (MAc)

[São Paulo] 11 maio 1939 a 2 jul 1940

Ms apresenta-se em 4 cadernos:

$1^{\circ}$ caderno: capa dura revestida de papel mármore verde; lombada em tecido preto; $24,5 \times 17,0 \mathrm{~cm}$; manchas e riscos de tinta preta; nota CJC a tinta preta no canto superior esquerdo: numeração do caderno: " 1 "; verso da capa: carimbo: "PAPELARIA E TYPOGRAPHIA | ANDREOTTI", dedicatória do escritor a MA em autógrafo a tinta preta: "A Mario de Andrade | homenagem de admiração e | simpatia | S. Paulo, maio 1943 | Cecilio J Carneiro"; miolo: autógrafo a tinta preta; papel branco, pautado: f. 2101; bordas estampadas de vermelho; 102 folhas; 23,4 x 15,9 cm; sinais de fungo; $\mathrm{f}$. 28: margem inferior: impressões digitais; f. 39: mancha de tinta vermelha; f. 101-102: canto superior esquerdo: mancha de tinta preta; f. 1: folha de rosto com as indicações: "Cecílio J. Carneiro | A Fogueira | Romance", "Caderno $\underline{1^{\circ}}$ | (1 a 100)"; escrita no anverso; rasuras a tinta preta; rasuras que se estendem até o verso; fólios numerados pela pesquisa: (1)-(1) (1) (5). Notas CJC: f. 1: a lápis: frase rasurada e contas; f. 2: a tinta preta: "11-5-39" [indicando o início da escrita do ms] e "Início da Revisão: 15-4-40"; f. 55: no verso a lápis preto: contas.

2 caderno: capa dura revestida de papel mármore verde; lombada em tecido marrom; $24,5 \times 17,0 \mathrm{~cm}$; Nota CJC a tinta preta no canto superior esquerdo: numeração do caderno: "2"; verso da capa: carimbo: "PAPELARIA E TYPOGRAPHIA | ANDREOTTI"; miolo: autógrafo a tinta preta; papel branco, pautado: f. 2-101; bordas: estampas vermelhas; 102 folhas; 23,4 x $15,9 \mathrm{~cm}$; sinais de fungo; escrita no anverso; rasuras a tinta preta; rasuras que se estendem para o verso; fólios numerados pela pesquisa: (1) (1) (6)- (2) (1) (9). Notas CJC: f. 1: "Caderno 2 $2^{\circ}$ (100 a 200)", f. 71 no verso: "A FOGUEIRA | Romance", f. 71 no verso: conta.

30 caderno: capa dura revestida com papel mármore preto e branco; lombada em percalina vermelha; $23,5 \times 16,0 \mathrm{~cm}$; Nota CJC a tinta preta no canto superior esquerdo: numeração do caderno: " $\underline{3}$ ”; verso da capa: selo da "PAPELARIA E TYPOGRAPHYA CASA ALPHA Ltd."; miolo: autógrafo a tinta preta; papel branco; pautado: f. 2-201; bordas: estampas azuis; 202 folhas; 22,7 x 15,6 cm; sinais de fungo; f. 33 no verso: mancha de tinta preta com marca de digital; f. 198-199 no verso: manchas de tinta preta; escrita no anverso; rasuras a tinta preta; rasuras que se estendem até o verso; fólios numerados pela pesquisa: (2) (1) (1)-(4) (1) (3). Notas CJC: f. 1: a tinta preta: " $\underline{\text { o }}$ caderno | 200 a 400"; f. 26: no verso esboços de desenho; f. 65 no verso: lista de 
assuntos tratados no romance; f. 68 no verso: data: "1912"; f. 115 no verso: data: "1920", nomes e respectivas idades; f. 163 no verso: "A FOGUEIRA"; f. 189 no verso: pontilhados a tinta preta.

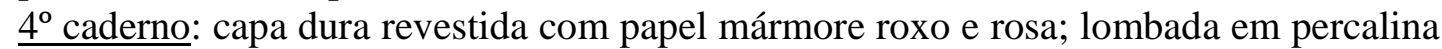
vermelha; 23,9 x 16,3 cm; nota CJC a tinta preta no canto superior esquerdo: numeração do caderno: "4"; verso da capa: selo da "PAPELARIA UNIVERSO"; miolo: autógrafo a tinta preta; papel branco; pautado: f. 2-101; bordas: estampas vermelhas; 102 folhas; $22,9 \times 15,5 \mathrm{~cm}$; sinais de fungo; f. 1: rasgamento na borda direita; f. 14 (no verso), 17, 26 (verso), 53: mancha de tinta; escrita no anverso; rasuras a tinta preta; rasuras que se estendem até o verso; fólios numerados pela pesquisa: (4) (1) (4)-(5) (1) (1). Notas CJC: f. 1: a tinta preta: “4 $4^{\circ}$ caderno | 400 a 500", "A FOGUEIRA | -Romance-", f. 51 no verso: desenho com a palavra "rio"; f. 96: "Fim |12-4-40 Fim da revisão: Noite de 2/7/40".

\section{Notas da pesquisa:}

1. Ms na vertente Mário de Andrade colecionador.

2. Há um exemplar de A fogueira (Rio de Janeiro, Jose Olympio, 1942) na biblioteca MA com a dedicatória: "Ao insigne ensaísta e poeta | brasileiro Mario Andrade, | com admiração e simpatia | oferece | Cecílio J. Carneiro | São Paulo, Fev. 1942.

3. O livro A fogueira foi traduzido na Inglaterra e nos Estados Unidos.

Estudo genético:

1. O ms apresenta-se em uma única versão, A, que mostra 2 etapas na escritura: a-a $a_{1}$ : a: autógrafo completo;

$\mathrm{a}_{1}$ : rasuras a tinta preta.

2. Versão A confrontada com a versão B, A fogueira (ed. cit.) mostra variantes.

\section{MA - MOE, 95}

CARVALHO, Ronald (1893-1935)

95. Estela para o corpo de uma mulher virgem; Humanidade; poesia (MAd)

[Rio de Janeiro], fev. 1923

Autógrafo a tinta preta; papel branco, filigrana; 1 folha; 27,7 x 21,9 cm; borda direita recortada; vincos; sinais de fungo; escrita no verso que se lê em datiloscrito a tinta preta exposição de problemas burocráticos de Associação cujo nome não é mencionado; rasuras a lápis preto; fólio numerado pela pesquisa: (1).

Notas da pesquisa:

1. Ms na vertente Mário de Andrade no diálogo interpares.

2. Local atestado com base nas cartas de RC a MA,datadas de 1923, todas são do Rio de Janeiro.

3. Entre 1923 e 1924, RC encaminhou a MA poemas que pretendia inserir no livro Jogos pueris, porém não há menção de títulos nas cartas trocadas entre eles.

4. O poema Estela para o corpo de uma mulher virgem está em Jogos pueris (ilustrado por Nicola Garo (pseudônimo de Nicolai Abracheff), impresso nas oficinas de Pimenta 
de Mello e Cia., tiragem com 40 exemplares especiais, assinados e numerados pelo autor, Rio de Janeiro, 1926).

5. O poema Humanidade não faz parte de Jogos pueris (ed. cit.).

6. Conforme o colofão, o exemplar na biblioteca de MA pertence à tiragem especial de 40 exemplares fora do mercado, em papel fabriciano pintado a mão por Nicola de Garo, numerados e rubricados a tinta preta pelo poeta: "Ronald de Carvalho | XXII | Mário de Andrade".

7. Uma edição fac-similar do livro foi realizada pela Imprensa Oficial do Estado e distribuída com o n 1 e 2 da revista D. O. Leitura, n. 1 e 2, janeiro/fevereiro de 2002.

Estudo genético:

1. O ms apresenta-se em uma única versão, A, que mostra 2 etapas na escritura: a-a : $_{1}$ a: autógrafo completo;

$\mathrm{a}_{1}$ : rasuras a lápis preto.

2. Versão A de Estela para o corpo de uma mulher virgem confrontada com a versão B, em Jogos pueris (ed. cit.); mostra variantes, entre elas a subscrição do título para "Inscrição para o corpo de uma mulher virgem".

\section{MA - MOE, 96}

CARVALHO, Ronald (1893-1935)

96. Antrhopomorphismo; Natureza morta; poesia (MAd)

[Rio de Janeiro, ant. 1926]

Datiloscrito, cópia carbono preto; títulos em datiloscrito original, fita vermelha; papel branco, filigrana; 27,0 x 20,5 cm; 2 folhas; vincos; sinais de fungo; escrita no anverso; autoria: "RONALD DE CARVALHO"; rasuras a máquina; fólios numerados pela pesquisa: (1)-(2). Nota RC a máquina: f. 1: margem inferior: "JOGOS PUERIS".

Notas da pesquisa:

1. Ms na vertente Mário de Andrade no diálogo interpares.

2. Data atestada com base no ano de publicação de Jogos pueris, 1926, (ilustrado por Nicola Garo - pseudônimo de Nicolai Abracheff - , impresso nas oficinas de Pimenta de Mello e Cia., com tiragem limitada de 40 exemplares, assinados e numerados pelo autor, Rio de Janeiro, 1926) onde está o poema Antrhopomorphismo.

3. Natureza morta não faz parte de Jogos pueris (ed. cit.).

4. Entre 1923 e 1924, RC encaminhou a MA poemas que fariam parte do livro Jogos pueris. A correspondência trocada entre os dois escritores atesta os envios, mas não há menção a título dos poemas.

5. Conforme o colofão, o exemplar na biblioteca de MA pertence à tiragem especial de 40 exemplares fora do mercado, em papel fabriciano pintado a mão por Nicola de Garo, numerados e rubricados a tinta preta pelo poeta: "Ronald de Carvalho | XXII | Mário de Andrade".

6. Uma edição fac-similar do livro foi realizada pela Imprensa Oficial do Estado e distribuída com o no 1 e 2 da revista D. O. Leitura, n. 1 e 2, janeiro/fevereiro de 2002. 
Estudo genético:

1. O ms apresenta-se em uma única versão, A, que mostra 2 etapas na escritura: a-a $a_{1}$ : a: datiloscrito completo; $\mathrm{a}_{1}$ : rasuras a máquina.

2. Versão A de Antrhopomorphismo foi confrontada com a versão B em Jogos pueris (ed. cit.). Há variantes.

\section{MA - MOE, 97}

\section{CARVALHO, Ronald (1893-1935)}

97. "Brincam as crianças na tarde quieta"; poesia (MAd)

[Rio de Janeiro, ant. 1926]

Datiloscrito original, fita preta; papel branco, filigrana; 1 folha; 32,8/32,9 x 22,4 cm; rasgamento na borda direita; vincos; sinais de fungo; escrita no anverso; assinatura a máquina: "Ronald de Carvalho"; rasura a máquina; fólio numerado pela pesquisa: (1).

\section{Notas da pesquisa:}

1. Ms na vertente Mário de Andrade no diálogo interpares.

2. Data atestada com base no ano de publicação de Jogos pueris, 1926, (ilustrado por Nicola Garo - pseudônimo de Nicolai Abracheff - , impresso nas oficinas de Pimenta de Mello e Cia., com tiragem limitada de 40 exemplares, assinados e numerados pelo autor, Rio de Janeiro, 1926) onde está "Brincam as crianças na tarde quieta".

3. Entre 1923 e 1924, RC encaminhou a MA poemas que pretendia inserir no livro Jogos pueris. A correspondência trocada entre os dois escritores atesta os envios, mas não há menção de título dos poemas.

4. Conforme o colofão, o exemplar na biblioteca de MA pertence à tiragem especial de 40 exemplares fora do mercado, em papel fabriciano pintado a mão por Nicola de Garo, numerados e rubricados a tinta preta pelo poeta: "Ronald de Carvalho | XXII | Mário de Andrade".

5. Uma edição fac-similar do livro foi realizada pela Imprensa Oficial do Estado e distribuída com o $\mathrm{n}^{\circ} 1$ e 2 da revista D. O. Leitura, n. 1 e 2, janeiro/fevereiro de 2002.

\section{Estudo genético:}

1. O ms apresenta-se em uma única versão, $A$, que mostra 2 etapas na escritura: $a-a_{1}$ : a: datiloscrito completo;

$\mathrm{a}_{1}$ : rasura a máquina.

2. Versão A confrontada com a versão B em Jogos pueris (ed. cit.), mostra variantes. 
MA - MOE, 98

CASCUDO, Luis da Câmara (1898-1986)

98. "Tarde morrendo em vermelho"; "Tardinha, tardinha"; "O chão é secco e vermelho, é vermelho"; poesia (MAm)

[Sertão do RN, 4 set. 1925]

Ms no corpo da carta de LCC a MA; datada: "4/IX/25"; assinada: "Luis da Camara Cascudo"; forma de tratamento: "Mario de Andrade"; autógrafo a tinta preta; papel branco, pautado, borda esquerda picotada; 1 folha; 33,0 x 11,0/ $11,2 \mathrm{~cm}$, com variação em $\mathrm{mm}$ na lagura; vincos; sinais de fungo; f. 3: rasgamento; poemas numerados por LCC a lápis azul: 1-3; escrita no anverso; f. 3: assinatura: a tinta preta: "Luis da Camara Cascudo"; rasuras a tinta preta; fólios numerados pela pesquisa: (1)(3).

(Ref. cruzada: série Correspondência Mário de Andrade - sub-série Correspondência passiva; MA-C-CPMVA, $\mathrm{n}^{\circ}$ 1783)

Notas da pesquisa:

1. Ms na vertente Mário de Andrade mentor.

2. Na carta de 4 de setembro de 1925 não consta local e deixa claro que LCC não estava em Natal, onde vivia: "Perdoe V. o papel. Estou no meio de vaqueiros |e cantadores. Não ha luz eletrica. [...] Depois d'amanã voltarei para | Natal”. A mesma missiva solicita a MA: "Mando três poemas para V. Leia-os, rasgue-os, publi | que-os. Como quizer. Chamei-os 1, 2 e 3. Se gostar | dê-lhos nome pela impressão que obtiver. São | absolutamente [?], authenticos, fiéis. | São seus".

3. A poesia LCC não saiu em livro.

Estudo genético:

1. O ms apresenta-se em uma única versão, A, que mostra 2 etapas na escritura: a-a $\mathrm{a}_{1}$ : a: autógrafo completo;

$\mathrm{a}_{1}$ : rasuras a tinta preta.

MA - MOE, 99

CASCUDO, Luis da Câmara (1898-1986)

99. Shimmy; poesia (MAm)

[Natal, ant. 25 maio 1926 ?]

Autógrafo a tinta preta; papel branco, pautado no anverso, filigrana; 1 folha; 27,5/

27,6 x 21,6/ 21,7 cm; vincos; sinais de fungo; escrita no anverso; dedicatória: "Ao

Mario de Andrade"; assinatura: "Luis da Camara Cascudo"; rasuras a tinta preta; fólio numerado pela pesquisa: (1). 
Notas da pesquisa:

1. Ms na vertente Mário de Andrade mentor.

2. LCC pode ter encaminhado o ms a MA junto da carta de [Natal] em 25 de maio de 1926, na qual está: "Jorge [Fernandes] viajou pro Sertão. [...] Incluí um retrato delle [Jorge Fernandes], versos e um | poeminha meu". (Ref.: série Correspondência Mário de Andrade - sub-série Correspondência passiva; MA-C-CPL, $\mathrm{n}^{\circ}$ 1790)

3. LCC enviou a MA alguns poemas do poeta rio-grandense do norte Jorge Fernandes. V. MA-MOE, 121, notas 2-3.

\section{Estudo genético:}

1. Ms apresenta-se em uma única versão, A, que mostra 2 etapas na escritura: $a-a_{1}$ : a: autógrafo completo; $\mathrm{a}_{1}$ : rasuras a tinta preta.

MA - MOE, 100

CASCUDO, Luis da Câmara (1898-1986)

100. "Não gosto de Sertão verde"; poesia (MAm)

[Natal ? ant. 6 jul. 1926]

Autógrafo a tinta preta; papel branco, pautado, borda esquerda picotada; 1 folha; 33 , 0 x 10,9/ 11,2 cm; vincos; sinais de fungo; escrita no anverso; visto do escritor; assinatura: "Luis da Camara Cascudo."; rasuras a tinta preta; fólio numerado pela pesquisa: (3). Nota LCC a tinta preta: "Prá Manuel Bandeira| é este".

Notas da pesquisa:

1. Ms na vertente Mário de Andrade mentor.

2. Local atestado com base na carta de LCC a MA, de Natal, em 25 de maio de 1926, pela qual se sabe que próximo ao dia 6 de julho o escritor se achava em Natal, onde morava (Ref.: série Correspondência Mário de Andrade - sub-série Correspondência passiva; MA-C-CPL, $n^{\circ}$ 1790).

3. Data atestada com base na publicação de "Não gosto de Sertão verde.", dedicado a Manuel Bandeira, na revista Terra Roxa, n 6, em São Paulo, 6 de julho de 1926.

4. Em 22 de julho de 1926 MA escreve a LCC e explica indiretamente a presença do ms em seu arquivo: "sim: recebi versos cartas revistas, recebi e li tudo, adorei tanto o Não Gosto de Sertão Verde que roubei êle por minha conta e já que você não quis mandar nada pra Terra Roxa dei o poema pros redatores que por sinal se entusiasmaram também. Aconselho apenas a escrever aquelas palavras escorre lento e a outra que não me lembro agora, naturalmente em horizontal".

5. Em carta a MA, datada do Rio de Janeiro, 25 de agosto de 1926, Manuel Bandeira manifesta-se sobre a homenagem: "[...] qual é o endereço do Luís da C. Cascudo? Quero oferecer o meu livro a ele. Li o poema da Terra Roxa e gostei muito" (Correspondência Mário de Andrade \& Manuel Bandeira. Ed. cit., p. 304).

6. A poesia de LCC não saiu em livro. 
Estudo genético:

1. O ms apresenta-se em uma única versão, A, que mostra 2 etapas na escritura: a-a $a_{1}$ : a: autógrafo completo;

$\mathrm{a}_{1}$ : rasuras a tinta preta.

MA - MOE, 101

CASCUDO, Luis da Câmara (1898-1986)

101. Crendices e tradições; pesquisa de folclore (MAd)

[Natal ?] s/ data

Autógrafo a tinta preta; papel branco, pautado, borda esquerda picotada; 1 folha; 32,8 x 10,9/11,0 cm; vincos; sinais de fungo; escrita no anverso; rasuras a tinta preta; fólio numerado pela pesquisa: (1). Nota LCC: "Os titulos sublinhados são | estudos da crendice colletivamente. As lettras marcam os | capitulos especiais. As crendices e tradições abrangem de Pernam- | buco ao Ceará, especialmente e caracteristicamente | o neu Estado. Ha muita novidade. O signal * | avisa os trabalhos terminados.”.

Notas da pesquisa:

1. Ms na vertente Mário de Andrade no diálogo interpares.

2. O ms traz uma relação de assuntos ligados ao folclore brasileiro pesquisados por LCC.

Estudo genético:

1. O ms apresenta-se em uma única versão, $A$, que mostra 2 etapas na escritura: a-a $a_{1}$ : a: autógrafo completo;

$\mathrm{a}_{1}$ : rasuras a tinta preta.

\section{MA - MOE, 102-111}

CASTRO, Arlindo de

102. Exaltação à imprensa; poesia (MAm)

[Guaxupé, MG, entre 1938-1941]

Datiloscrito original fita preta; papel branco, filigrana; 1 folha; 19,1/ 19,7 x 21,5 cm; parte inferior da folha recortada; vincos; sinais de fungo; escrita no anverso; rasuras a tinta roxa; fólio numerado pela pesquisa: (2). Nota AC a tinta azul no verso: "de | 1938 | 1939 | 1940 | 1941 | Guaxupé”.

Notas MA a lápis preto: "Metrificação frouxa", "Não basta".

103. $O$ charco; poesia (MAm)

[Guaxupé, MG], 1940

Datiloscrito original fita preta; papel branco; 1 folha; 26,1 x 20,2/ 20,3 cm; vincos; sinais de fungo; manchas de tinta azul; escrita no anverso; assinatura a tinta azul: "Arlindo Castro"; rasuras a máquina, a tinta azul e a tinta roxa; fólio numerado pela 
pesquisa: (3). Notas AC a tinta azul na margem superior: "Em 1940", no verso: relação de nomes.

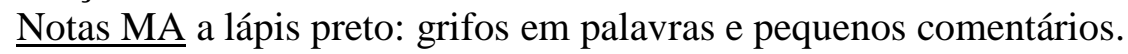

104. Prece; poesia (MAm)

[Guaxupé, MG], 1940

Datiloscrito original fita preta; papel branco, pautado; 1 folha; 25,6 x 20,4 cm; vincos; sinais de fungo; escrita no verso; assinatura a tinta azul: "Arlindo Castro"; rasuras a máquina; fólio numerado pela pesquisa: (4). Nota $\mathrm{AC}$ a tinta azul na margem superior: "Em 1940".

105. Atavismo terrestre; poesia (MAm)

[São Paulo, ant. mar. 1943]

Datiloscrito cópia carbono roxo; papel branco; 1 folha; 26,1 x 20,3/ 20,4 cm; vincos; sinais de fungo; manchas de carbono; escrita no anverso; rasuras a máquina e a tinta azul; fólio numerado pela pesquisa: (5).

106. $O$ carro de bois; poesia (MAm)

[São Paulo, ant. mar. 1943]

Datiloscrito cópia, carbono roxo; papel branco; 1 folha; 26,2 x 20,3/ 20,4 cm; vincos; sinais de fungo; manchas de carbono; escrita no anverso; rasuras a máquina e a tinta preta; fólio numerado pela pesquisa: (6).

Notas MA a lápis preto: grifos destacando trechos e comentário: "Francamente péssimo!”.

107. Pêso morto; poesia (MAm)

[São Paulo, ant. mar. 1943]

Datiloscrito cópia carbono roxo; papel branco; 1 folha; 26,2 x 20,3/ 20,4 cm; vincos; sinais de fungo; manchas de carbono; escrita no anverso; rasuras a máquina e a tinta preta; fólio numerado pela pesquisa: 7 .

108. Brincando de fazer poesia; poesia (MAm)

[São Paulo, ant. mar. 1943]

Datiloscrito cópia carbono roxo; papel branco; 1 folha; 26,2 x 20,3/ 20,4 cm; vincos; sinais de fungo; manchas de carbono; escrita no anverso; rasuras a máquina e a tinta preta; fólio numerado pela pesquisa: 7 .

109. Sinos de Belem; poesia (MAm)

[São Paulo, ant. mar. 1943]

Datiloscrito cópia carbono roxo; papel branco; 1 folha; 26,2 x 20,3/ 20,4 cm; vincos; sinais de fungo; manchas de carbono; manchas de tinta azul; escrita no anverso; rasuras a máquina, a tinta preta e azul; fólio numerado pela pesquisa: (8).

110. Ter mãe; poesia (MAm)

São Paulo, 1943

Datiloscrito cópia carbono roxo; papel branco; 1 folha; 26,2 x 20,3/ 20,4 cm; vincos; sinais de fungo; manchas de carbono; escrita no anverso; rasuras a máquina, a tinta 
preta e azul; fólio numerado pela pesquisa: (9). Nota AC a tinta azul: margem superior: "no 1", no verso: "de | 1943 | São Paulo".

111. Preto-ponte; poesia (MAm)

[São Paulo, 1943]

Datiloscrito cópia, carbono roxo; papel branco; 2 folhas; 26,2 x 20,3/ 20,4 cm; vincos; sinais de fungo; manchas de carbono; escrita no anverso; folhas numeradas pelo escritor: 1-2; assinatura a tinta azul: "Arlindo de Castro"; f. 1-2: rasuras a máquina, f. 2: rasuras a tinta azul; fólios numerados pela pesquisa: (1) (1)-(1) (1). Notas AC: a máquina na f. 2: "( Do livro em preparo-MARAVALHAS)", a tinta azul na margem superior: " $n$ ' 2 ".

Nota MA a lápis na f. 2: grifo na palavra "MARAVALHAS".

\section{Anexos:}

1) Carta AC a MA; datada: "São Paulo - março - 43"; assinada: "Arlindo de Castro"; forma de tratamento: "Snr Mario"; autógrafo a tinta azul; papel branco, pautado no anverso; 1 folha; 25,6 x 20,3/20,4 cm; vincos; sinais de fungo; escrita no anverso; fólio numerado pela pesquisa: (1). PS na margem esquerda.

(Ref. cruzada: série Correspondência Mário de Andrade - sub-série Correspondência passiva; MA-C-CPMVA, $\mathrm{n}^{\circ}$ 1899)

2) Envelope branco para acondicionamento dos $\mathrm{ms} ; 12,1 \times 13,0 / 15,2 \mathrm{~cm}$; borda esquerda rasgada; sinais de fungo; fólio numerado pela pesquisa: (1) (2). Notas AC a tinta preta: "Modernismo | Experimental | de 1942 a 43. | Arlindo de Castro". Nota MA a lápis preto: comentário sobre a poesia de Arlindo de Castro.

Notas da pesquisa:

1. Ms na vertente Mário de Andrade mentor.

2. Local e data de Atavismo terrestre, O carro de bois, Brincando de fazer poesia e Sinos de Belem atestados com base na carta de AC a MA, de São Paulo, em março de 1943, acima citada.

3. Local e data de Preto-ponte atestados com base na data no ms de Ter mãe. Ambos os ms se apresentam no mesmo tipo de papel e de escrita, e estão numerados pelo escritor: "no 1 " e "no 2 "

4. Na única carta de CA que se encontra na série Correspondência Mário de Andrade, no IEB-USP, datada de São Paulo, março de 1943, o remetente escreve: "Confórme falamos, mando-lhe | meus "versos" que, (se me permi- | te) não são propriamente uma | diarreia-lírica, uma delinquencia- | literária. [...] Assim sendo, aguardo seu valioso | parecer a respeito deles".

Estudo genético:

1. Os ms apresentam-se em uma única versão, A.

2. Prece mostra 2 etapas na escritura: $\mathrm{a}-\mathrm{a}_{1}$ :

a: datiloscrito completo;

$\mathrm{a}_{1}$ :rasuras a máquina.

3. Exaltação à imprensa mostra 2 etapas na escritura: a-a $a_{1}$ :

a: datiloscrito completo;

$\mathrm{a}_{1}$ : rasuras a tinta roxa. 
4. O charco mostra 4 etapas na escritura: $\mathrm{a}_{-}-\mathrm{a}_{1}-\mathrm{a}_{2}-\mathrm{a}_{3}$ :

a: datiloscrito completo;

$\mathrm{a}_{1}$ : rasuras a máquina;

$\mathrm{a}_{2} ;$ rasuras a tinta azul;

$\mathrm{a}_{3}$ : rasuras a tinta roxa.

5. Atavismo terrestre e Preto-ponte mostram 3 etapas na escritura: $\mathrm{a}_{-} \mathrm{a}_{1}-\mathrm{a}_{2}$ :

a: datiloscrito completo;

$\mathrm{a}_{1}$ : rasuras a máquina;

$\mathrm{a}_{2}$ : rasuras a tinta azul.

6. O carro de bois, Pêso morto e Brincando de fazer poesia mostram 3 etapas na escritura: $\mathrm{a}-\mathrm{a}_{1}-\mathrm{a}_{2}$ :

a: datiloscrito completo;

$\mathrm{a}_{1}$ : rasuras a máquina;

$\mathrm{a}_{2}$ : rasuras a tinta preta.

7. Sinos de Belem e Ter mãe mostram 4 etapas na escritura: $\mathrm{a}-\mathrm{a}_{1}-\mathrm{a}_{2}-\mathrm{a}_{3}$ :

a: datiloscrito completo;

$\mathrm{a}_{1}$ : rasuras a máquina;

$a_{2}-a_{3}$ : rasuras a tinta azul e preta, sem possibilidade de identificar a ordem das etapas.

8. É possível que o comentário MA no envelope, fólio 12, seja uma nota prévia para carta endereçada a AC.

\section{MA - MOE, 112}

CASTRO, Moacyr Weneck de (1915-)

112. A revolução praieira; ensaio (MAm) / (MAc)

[Rio de Janeiro, ant. 13 nov. 1941]

Autógrafo a lápis preto; datiloscrito original fita preta e vermelha; papel branco, pautado: f. 10-18; 18 folhas; f. 1: 21,9/22,0 x 16,3/16,6 cm, f. 2-3, 5-8: 27,6 x 21,3 cm, f. 4: $24,5 / 26,5$ x 21,8/21,9 cm, f. 9: $21,7 / 22,0$ x 21,2 cm, f. $10-18: 23,1 \mathrm{x}$ 15,5/16,0 com variações em mm; f. 1: rasgamentos nas bordas; f. 4: borda inferior rasgada; f. 10-11: borda direita irregular; f. 12-18: borda esquerda irregular; sinais de fungo; escrita no anverso; f. 2-3, 5-9: parte do texto da peça teatral Rio, de Carlos Lacerda; rasuras a lápis; fólios numerados pela pesquisa: (1)-(1) (8).

Nota MA a tinta preta: f. 1: "Parte dos originais de | 'O Rio' | de Carlos Lacerda | (nas costas da mesmo vem | parte dos originas de | 'A Revolução Praieira' | de | Moacir Werneck de Castro)".

Notas da pesquisa:

1. Ms nas veretentes Mário de Andrade mentor e Mário de Andrade colecionador.

2. Local e data atestados com base na carta Carlos Lacerda a MA, do Rio de Janeiro, 13 de novembro de 1941: "Tenho agora remexido melhormente em papéis desencontrados, desarrumados nesses | encontrões que se vai tomando na vida. Por isso mesmo, tenho conseguido encontrar | os originais de 'O Rio', que você certa vez pediu tanto por carinho quanto por mania. | Mando agora, junto com esta carta, algumas paginas, atrás das quais - ou na frente das | quais, não me lembro mais - o Moacir escreveu outros 
originais, os do estudo dele | sobre a Praieira. Assim, fica valorizado o original do ' $O$ Rio'... O resto mandarei | assim que encontrar, e será dentro de poucos dias”. (Ref.: série Correspondência Mário de Andrade - sub-série Correspondência passiva; MA-CCPL, $n^{\circ} 3850$ )

3. V. análise documentária do ms Rio, de Carlos Lacerda, MA-MOE, 187.

Estudo genético:

1. O ms apresenta-se em uma única versão, A, que mostra 2 etapas na escritura: a-a $a_{1}$ : a: datiloscrito completo;

$\mathrm{a}_{1}$ : rasuras a lápis preto.

\section{MA - MOE, 113}

CASTRO, Moacyr Werneck de (1915-)

113. O poeta Mario de Andrade; ensaio (MAm)

[Rio de Janeiro, 1941]

Datiloscrito, cópia carbono azul; papel branco; 6 folhas; 31,8 x 21,9 cm; vincos; sinais de fungo; f. 6: furos e pequenos ragamentos nas bordas; escrita no anverso; folhas numeradas pelo escritor: 1-6; f. 6: assinatura MWC a tinta preta; rasuras: a máquina e a tinta preta; fólios numerados pela pesquisa: (1)-(6).

Notas da pesquisa:

1. Ms na vertente Mário de Andrade mentor.

2. Data atestada com base na publicação de Poesias, São Paulo, Livraria Martins Editora, 1941, referida no ms: "Agora, [...], Mário de | Andrade, um dos cheges mais representativos do movmento, reune em volume | o principal de sua contribuição poética, desde a | Paulicéia Desvairada"'.

Estudo genético:

1. O ms apresenta-se em uma única versão, A, que mostra 3 etapas na escritura: $a-a_{1}-a_{2}$ : a: datiloscrito completo;

$\mathrm{a}_{1}$ : rasuras a máquina; $\mathrm{a}_{2}$ : rasuras a tinta preta.

\section{MA - MOE, 114}

\section{CHIARINI, João (1919-?)}

114. Batuque; Resto de África; Negro Véio; Ventre da terra; Rússia; poesia (MAm)

[Piracicaba, SP, ant. 31 ago. 1943]

Datiloscrito, cópia carbono azul, carbono preto, cópia carbono roxo; datiloscrito original fita preta; papel seda, rosa e branco; f. 1, 8: pasta de cartolina verde acondicionando as folhas com os poemas; 6 folhas unidas por 3 grampos enferrujados e coladas na pasta; 31,1 x 21, $3 \mathrm{~cm}$; vincos no canto superior direito; sinais de fungo; 
f. 2: manchas de tinta vermelha na margem esquerda e ferrugem de grampo no verso; f. 6: mancha de tinta vermelha; f. 4, 6-7: manchas de carbono; f. 6-7: 2 furos na margem inferior à esquerda; escrita no anverso; abaixo dos títulos; assinatura a máquina: "JoãoChiarini" e assinaturas a tinta preta e vermelha; rasuras a máquina, a tinta preta e vermelha; fólios numerados pela pesquisa: (1)-(8).

Notas da pesquisa:

1. Ms na vertente Mário de Andrade mentor.

2. Local e data atestados com base na carta de JC a MA, de Piracicaba, 31 de agosto de 1943, onde se lê: "Junto remeto-lhe | umas poesias. Desejaria a e muito agrade- | cerei sí você pudesse opinar sôbre elas. | 'Batuque' eu fixei como | êle o é aquí. Brevemente lhe remeterei | 'Gesto do Divino'. Outra poesia”. A mesma missiva convalida o papel de MA correspondente: "eu tinha certeza de que | a sua resposta vinha. Não porque a Cecilia | Meireles já se referiu uma vez ao cui- | dado que você tem com a correspondên- | cia-epistolar".

3. JC encaminhou a MA outra versão de Rússia junto da carta datada de Piracicaba em 20 de setembro de 1943, na qual agradece os comentários feitos por MA aos poemas do ms acima registrado (V. MA-MOE, 115).

4. Os poemas ficaram inéditos, ao que se sabe.

\section{Estudo genético:}

1. Batuque, Resto de África, Negro Véio e Ventre da terra apresentam-se em uma única versão, A. Rússia apresenta-se em 2 versões, sendo a acima registrada considerada A pela pesquisa. Há variantes entre ambas versões (V. análise documentária da versão B, MA-MOE, 115).

2. Negro Véio mostra 2 etapas na escritura: $\mathrm{a}-\mathrm{a}_{1}$ :

a: datiloscrito completo;

$\mathrm{a}_{1}$ : rasuras a tinta vermelha.

3. Resto de África, Ventre da terra e Rússia mostra 3 etapas na escritura: a-a $\mathrm{a}_{1}-\mathrm{a}_{2}$ :

a: datiloscrito completo;

$\mathrm{a}_{1}$ : rasuras a máquina;

$\mathrm{a}_{2}$ : rasura a tinta vermelha.

4. Batuque mostra 4 etapas na escritura: $\mathrm{a}-\mathrm{a}_{1}-\mathrm{a}_{2}-\mathrm{a}_{3}$ :

a: datiloscrito completo;

$\mathrm{a}_{1}$ : rasuras a máquina;

$\mathrm{a}_{2}-\mathrm{a}_{3}$ : rasuras a tinta preta e a tinta vermelha.

\section{MA - MOE, 115}

\section{CHIARINI, João (1919-?)}

115. Rússia; poesia (MAm)

[Piracicaba, SP, ant. 20 set. 1943]

Datiloscrito, cópia carbono preto; papel seda, branco; 1 folha; 32,5/32,8 x 21,9 cm; 3 furos no canto superior esquerdo; 2 rasgamentos na margem esquerda; vincos; sinais de fungo; escrita no anverso; assinatura a máquina: "João Chiarini”; rasuras a máquina, a 
lápis, a tinta vermelha e tira de papel com dois versos datilografados substituindo os três últimos versos do poema; fólio numerado pela pesquisa: (1).

Notas da pesquisa:

1. Ms na vertente Mário de Andrade mentor.

2. Local e data atestados com base na carta de JC a MA, datada de Piracicaba, 20 de setembro de 1943. O remetente agradece e comenta a opinião de MA sobre os poemas enviados em 31 de agosto de 1943 e encaminha nova versão de Rússia: "agradeço a sua opi- | nião sôbre meus versos. Concor- | do com as suas observações ple- | namente. Menos com uma: 'fomen- | to' em 'poesia' póde ser. Nos vive- $\mid$ mos uma época industrial. Ane- | xo-lhe nova copia do 'Russia' | e com o uso das suas notifi- | cações".

3. Sobre a versão anterior do poema Rússia encaminhada a MA, V. MA-MOE, 114.

4. O poema permaneceu inédito, pelo que se sabe.

Estudo genético:

1. O ms é segunda versão do poema enviada a MA, pela pesquisa considerada $B$, e que mostra 4 etapas na escritura: $a-a_{1}-a_{2}-a_{3}$ :

a: datiloscrito completo;

$\mathrm{a}_{1}$ : rasuras a máquina;

$a_{2}-a_{3}$ : rasuras a tinta vermelha e a lápis preto.

2. Há variantes entre as versões A e B.

\section{MA - MOE, 116}

DAMANTE, Francisco (1895-1927)

116. Vontade de casar; folclore (MAc)

[Perdões], s/ data

Autógrafo a tinta preta; papel branco e pautado, timbrado: ““'O ESTADO DE S. PAULO" | Redação"; 3 tiras de papel coladas com fita adesiva e cola formando 1 folha; 48,1/48,2 x 10,7/11,8 cm; rasgamentos nas bordas; vincos; sinais de fungo; escrita no anverso; autoria no final de cantiga intitulada Coitada: "Antonio Alexandrino"; rasuras: a tinta preta; fólio numerado pela pesquisa: (1). Nota FD na margem direita: " 8 ".

Nota MA a lápis preto: o título "Vontade de casar".

\section{Notas da pesquisa:}

1. Ms na vertente colecionador.

2. Local atestado com base na carta de FD a MA, de Perdões em maio de 1920, junto junto da qual o remetente envia outras cantigas de roda recolhidas na mesma cidade. (Ref.: série Correspondência Mário de Andrade - sub-série Correspondência passiva; MA-C-CPMMA, n 2413) 
Estudo genético:

1. O ms apresenta-se em uma única versão, A, que mostra 2 etapas na escritura: a-a $a_{1}$ : a: autógrafo completo;

$\mathrm{a}_{1}$ : rasuras a tinta preta.

\section{MA - MOE, 117}

DEL PICCHIA, Menotti (Paulo Menotti Del Picchia 1892-1988)

117. Lôa do embarque; poesia (MAd)

[São Paulo], s/ data

Datiloscrito original; fita preta; papel branco, timbrado: "União Jornalística Brasileira"; 28,7 x 21,9; vincos; sinais de amassado; sinais de fungo; ferrugem de clipe na borda esquerda do verso; escrita no anverso; assinatura a tinta preta: "Menotti del Picchia"; rasuras a máquina e a tinta preta; fólio numerado pela pesquisa: (2). Notas MA a lápis preto: colchete na margem esquerda da $2^{\mathrm{a}}$ estrofe.

Notas da pesquisa:

1. Ms na vertente Mário de Andrade no diálogo interpares.

2. Entre as cartas de MDP, na série Correspondência Mário de Andrade no IEB-USP, há algumas apenas uma, de [São Paulo], s/ data, que menciona envio de poema, sem explicitar título, possivelmente o ms acima registrado: "Como estou velho para fazer poesia, | da musa encarquilhada sahiu o que ahi vae". (Ref.: série Correspondência Mário de Andrade - sub-série Correspondência passiva; MA-C-CPL, nº 2434)

Estudo genético:

1. O ms apresenta-se em uma única versão, A, que mostra 3 etapas na escritura: $a-a_{1}-a_{2}$ : a: datiloscrito completo;

$\mathrm{a}_{1}$ : rasuras a máquina;

$\mathrm{a}_{2}$ : rasuras a tinta preta.

\section{MA - MOE, 118}

DUARTE, Paulo (Paulo Alfeu Junqueira Monteiro Duarte 1899-1984)

118. "Brasileiros, boa noite."; conferência (MAc)

Nova Iorque, 5 fev. 1942

Datiloscrito, cópia carbono preto; papel seda, branco; 5 folhas; 28,1/ 21,2 x 21,8 cm; vincos; sinais de fungo; furos de grampo; manchas de carbono; f. 1: rasgamento na borda esquerda; vinco nos cantos inferior e superior esquerdo; escrita no anverso; f. 1: local e data: "New York, 5.2.42"; rasuras a máquina e a tinta preta. Nota PD a tinta preta na margem superior da f. 1: "Mr. Mario de Andrade | Rua Lopes Chaves, 546 | S. Paulo (Brasil)".

Nota MA a lápis preto na margem superior da f. 1: "Paulo Duarte | lido na N.B.C.". 
Notas da pesquisa:

1. Ms na vertente Mário de Andrade colecionador.

2. O ms traz fala radiofônica de Paulo Duarte na National Broadcasting Corporation (NBC), em Nova Iorque, focalizando o livro Poesias de Mário de Andrade (São Paulo, Livraria Martins Editora, 1941).

3. Paulo Duarte foi exilado por duas vezes, em 1932, por ocasião da Revolução Constitucionalista, e em 1938, pelo Estado Novo da ditadura Vargas. O último exílio, vivido nos Estados Unidos, em Nova Iorque, durou 9 anos. Em 1942, o jornalista mantinha na rádio NBC um programa semanal sobre livros brasileiros.

4. Na carta a MA, de 7 de março de 1942, PD focaliza o ms: "Hontem, a NBC deve ter enviado a você uma copia da minha cronica sobre o seu livro. Pela carta ao Rubens você já sabe que estou fazendo uma palestra semanal sobre livros brasileiros. Realizei umas oito e a ultima foi sobre o seu livro" (DUARTE, Paulo. Mário de Andrade por ele mesmo. São Paulo, Edart, 1971, p. 223).

\section{Estudo genético:}

1. O ms apresnta-se em uma única versão, $A$, que mostra 3 etapas na escritura: $a_{-} a_{1}-a_{2}$ : a: datiloscrito completo;

$\mathrm{a}_{1}$ : rasuras a máquina;

$\mathrm{a}_{2}$ : rasuras a tinta preta.

\section{MA - MOE, 119}

ERISMANN, Georgina de Mello

119. Inclemencia; Rêde; Camponeza; Sanfona; poesia (MAm)

S/ local, s/ data

Datiloscrito, cópia carbono azul; papel branco, filigrana; 4 folhas; 26,9 x $21,1 \mathrm{~cm}$; f. 1 2: borda inferior amassada com pequenos rasgamentos; f. 3-4: marcas de amassado; f. 3: 1 furo no centro do papel; f. 4: pequeno rasgamento na borda esquerda; vincos; sinais de fungo; manchas de carbono; escrita no anverso; assinatura a máquina no final do poema: "GEORGINA DE MELLO ERISMANN"; rasura a tinta preta a máquina e a lápis preto; fólios numerados pela pesquisa: (1)-(4).

\section{Inclemencia:}

Nota MA a lápis vermelho: numeração da folha: “2”.

Rêde:

Nota MA a lápis vermelho: numeração da folha: "8".

\section{Camponeza:}

Nota MA a lápis vermelho: numeração da folha: "10".

\section{Sanfona:}

Nota MA a lápis vermelho: numeração da folha: 11 . 
Notas da pesquisa:

1. Ms na vertente Mário de Andrade mentor.

2. Na série Correspondência Mário de Andrade no IEB-USP não há cartas de GME que comprovem o envio do ms. Há apenas um cartão-postal datado de Feira de Santana, 4 de janeiro de 1937. (Ref.: série Correspondência Mário de Andrade - sub-série Correspondência passiva; MA-C-CP, $\mathrm{n}^{\circ} 2586$ )

Estudo genético:

1. O ms apresenta-se em uma única versão, A.

2. Rêde e Camponeza mostram 1 etapa na escritura.

3. Inclemencia mostra 2 etapas na escritura: $\mathrm{a}_{-} \mathrm{a}_{1}$ :

a: datiloscrito completo;

$\mathrm{a}_{1}$ : rasura a tinta preta.

4. Sanfona mostra 3 etapas na escritura: $\mathrm{a}-\mathrm{a}_{1}-\mathrm{a}_{2}$ :

a: datiloscrito completo;

$\mathrm{a}_{1}$ : rasura a máquina;

$\mathrm{a}_{2}$ : rasuras a lápis preto.

\section{MA - MOE, 120}

FARIA, Otavio de (1908-1980)

120. Fronteiras da santidade (Pascal e Léon Blay); ensaio (MAc)

Rio de Janeiro, out. 1938

Autógrafo a tinta azul: f. 1-78, 190-232; autógrafo a tinta preta: f. 77, 79-189; papel branco, pautado no anverso, filigrana; 232 folhas; $23,3 \times 15,9 \mathrm{~cm}$, com variações de $\mathrm{mm}$; sinais de fungo; f. 7: rasgamentos na borda direita; f. 103: 2 vincos no canto inferior esquerdo; f. 143, 231: 1 furo na borda inferior; f. 192: rasgamento na borda inferior; f. 198, 208, 213, 215, 217, 219-220, 227-228, 230-232: mancha de tinta azul no verso; escrita no anverso; local e data: f. 6: "Rio, Outubro - 1938."; folhas numeradas pelo escritor; rasuras a tinta azul, a tinta preta e, f. 226: a lápis preto; fólios numerados pela pesquisa: (1)-(2) (3) (2).

\section{Anexos:}

1) Bilhete: datado: "Rio - 22-9-40"; s/ assinatura, s/ forma de tratamento; cartão de visita; impresso: "OCTAVIO DE FARIA"; autógrafo a tinta azul; cartão branco, 5,6 x 9,2 cm; escrita no anverso; fólio numerado pela pesquisa: (1). Texto: "com os mais sinceros agra- | decimentos pela idéa tão | amavel, | oferece cordialmente".

2) Envelope branco forrado de papel de seda verde; indicação de destinatário e portador em autógrafo a tinta azul: " $\mathrm{Ex}^{\mathrm{mo}} \mathrm{Sn}^{\mathrm{r}} \mid$ Mario de Andrade |- p.e.f. do $\mathrm{Sn}^{\mathrm{r}}$ Vinicius de Moraes"; fólio numerado pela pesquisa: (2).

Notas da pesquisa:

1. Ms na vertente Mário de Andrade colecionador.

2. A disposição gráfica no $\mathrm{ms}$ assemelha-se à de um livro. 
3. O ensaio foi publicado como livro, com exemplar a MA presente na biblioteca do escritor: FARIA, Otávio de Fronteiras da santidade São Paulo, "Cadernos da Hora Presente"/ SEP, 1940. Traz a dedicatória: "a Mario de Andrade, | sincera homenagem de | Octavio de Faria | Rio - Abril de 1940.”. Na aba esquerda, está entre os trechos da crítica sobre a obra reproduzidos, um assinado Mário de Andrade. O exemplar não oferece notas da leitura de MA.

4. O bilhete que acompanha o ms é o único documento relativo a OF na sub-série Correspondência Passiva da série Correspondência. Na Correspondência ativa, na mesma série, encontra-se cópia de carta que MA endereçou em 5 de novembro de 1937 comentando Mundos mortos (José Olympio, 1937) do escritor carioca. Foi publicada por Marcos Antonio de Moraes na Revista do IEB, n. 36, São Paulo, 1994, p. 184-189.

Estudo genético:

1. O ms apresenta-se em uma única versão, A, que mostra 4 etapas na escritura: $a-a_{1}-a_{2}-a_{3}$ : a: autógrafo completo;

$\mathrm{a}_{1}$ : autógrafo a tinta azul;

$\mathrm{a}_{2}$ : autógrafo a tinta preta;

$\mathrm{a}_{3}$ : rasura a lápis preto.

2. Versão A confrontada com a versão B: Fronteiras da santidade (ed. cit.). Há variações entre ambas versões.

\section{MA - MOE, 121}

FERNANDES, Jorge (1887-1957)

121. Relogio...; Rondo das rendas...; poesia (MAm)

[Natal], 20 maio 1926

Datiloscrito, cópia carbono roxo; papel branco; 1 folha; 26,9 x 20,6 cm; vincos; sinais de fungo; escrita no anverso; data e assinatura a tinta preta: "20/5/26", "Jorge Fernandes"; rasuras a máquina e a tinta preta; fólio numerado pela pesquisa: (1). $\underline{\text { Notas JF e Notas de Luís da Câmara Cascudo. }}$

Relogio...:

Nota JF a máquina: “(Pensamento Liberto | da Cella No 14 (Soneto)". Notas de Luís da Câmara Cascudo a tinta preta: substituição de palavra na Nota JF: "(Pensamento Liberte enviado [...]" e observação para MA ao lado esquerdo da Nota JF: " Nome | do | livro. | (Quer?)".

Rondo das rendas....:

NotaJF a máquina: “(Pensamento Evadido | da Cella N 14 (Soneto)”. Notas de Luís da Câmara Cascudo a tinta preta na margem inferior: glossário esclarecendo a MA o significado de três palavras do poema. 
Notas da pesquisa:

1. Ms na vertente Mário de Andrade mentor.

2. Os poemas no ms foram provavelmente encaminhados a MA por Luís da Câmara Cascudo junto da carta, de [Natal], 25 de maio de 1925, na qual se lê: "Jorge viajou pro Sertão. [...] Incluí um retrato delle, versos e um | poeminha meu". (Ref.: série Correspondência Mário de Andrade - sub-série Correspondência passiva; MA-C-CPL, $\left.\mathrm{n}^{\circ} 1790\right)$

3. Câmara Cascudo já havia enviado poemas de JF a MA, conforme se observa na carta de Natal, 9 de março de 1925: "[...] Jorge Fernandes existe. É homem re- | traido, altivo, amigo de três ou quatro [...]. Remetto alguns poemas delle publi- | cados n'A imprensa". (Ref.: série Correspondência Mário de Andrade - sub-série Correspondência passiva; MA-C-CPL, $n^{\circ} 1774$ )

4. Relogio... foi publicado em Livro de poemas. Natal, Tipografia da Imprensa de Natal, 1927.

5. Rondo das rendas... permaneceu inédito, ao que se sabe.

6. Na biblioteca MA há um exemplar de Livro de poemas (ed. cit.), com Notas MA a lápis preto e a dedicatória: "Ao meu grande | Mario o meu | livro todo errado | 14-3-928".

7. Sobre Livro de poemas MA escreveu em 12 de janeiro de 1929, para o Diário Nacional na coluna assinada "Mário de Andrade". O mesmo texto encontra-se em Turista Aprendiz de Mário de Andrade (São Paulo, Livraria Duas Cidades/ Secretaria da Cultura, Ciência e Tecnologia, 1976), nas anotações do dia 19 de dezembro.

Estudo genético:

1. O ms apresenta-se em uma única versão, A, que mostra em Rondo das rendas... 2 etapas na escritura: $a-a_{1}$, e em Relogio... 3 etapas na escritura: $a_{-} a_{1}-a_{2}$ :

a: datiloscrito completo;

$\mathrm{a}_{1}$ : rasuras a máquina;

$\mathrm{a}_{2}$ : rasura a tinta preta.

2. Versão A de Relógio confrontada com a versão B em Livro de poemas (ed. cit.),mostra variantes.

\section{MA - MOE, 122-123}

FERNANDES, Jorge (1887-1957)

122. Poemas das serras; poesia (MAm)

Natal/RN, [ant. 1 jul. 1926]

Datiloscrito, cópia carbono roxo; papel branco; 1 folha; 26,9 x 20,6/ 20,9 cm; vincos; sinais de fungo; manchas de carbono; escrita no anverso; poema numerado pelo escritor: "I"; assinatura do escritor e local a tinta preta: "Jorge Fernandes | Natal"; rasuras a máquina e a tinta preta; fólio numerado pela pesquisa: (1).

Notas MA a lápis preto: correções. 
123. "Casa dos mocós... das saramantas..."; poesia (MAm)

[Natal/RN, ant. 1 jul. 1926]

Datiloscrito, cópia carbono roxo; papel branco; 1 folha; 13,5/ 13,6 x 20,5; borda inferior recortada; vincos; sinais de fungo; manchas de carbono; escrita no anverso; poema numerado pelo escritor: "III"; fólio numerado pela pesquisa: (1).

Notas da pesquisa:

1. Ms na vertente Mário de Andrade mentor.

2. Data atestada com base na carta de JF a MA, de Natal, 1 de julho de 1926, na qual se lê: "Vão ahi algumas impressões que juntei entre serras | do meu Estado" (Ref.: série Correspondência Mário de Andrade - sub-série Correspondência passiva; MA-C-CPL, $\mathrm{n}^{\mathrm{o}}$ 2698).

3. Poemas das serras foi publicado Livro de poemas (Natal, Tipografia da Imprensa de Natal, 1927), com o título "Poemas das serras I".

4. V. MA-MOE, 121, notas 2-3,6-7.

Estudo genético:

1. O ms apresenta-se em uma única versão, A, que mostra 2 etapas na escritura: $a-a_{1}$ : a: datiloscrito completo; $\mathrm{a}_{1}$ : rasuras a tinta preta.

2. Versão A confrontada com a versão B em Livro de poemas (ed. cit.), exibe variantes entre ambas versões.

\section{MA - MOE, 124-126}

FERNANDES, Jorge (1887-1957)

124. Canção ao sol; poesia (MAm)

[Natal, ant. 26 ago. 1926]

Datiloscrito, cópia carbono roxo; papel branco, pautado no anverso; 1 folha; 27,2/ 27,3 x $21 \mathrm{~cm}$; vincos; sinais de fungo; manchas de carbono; marcas de clipe na margem superior; ferrugem de clipe no verso; escrita no anverso; assinatura a tinta preta: "Jorge Fernandes"; fólio numerado pela pesquisa: (1).

125. Nordestinas (Avoetes); poesia (MAm)

[Natal, ant. 26 ago. 1926]

Datiloscrito, cópia carbono roxo; papel branco, pautado no anverso; 1 folha; 27,2/ 27,3 x $21 \mathrm{~cm}$; vincos; sinais de fungo; manchas de carbono; marcas de clipe na margem superior; escrita no anverso; rasuras a máquina e a tinta preta; assinatura a tinta preta: "Jorge Fernandes"; fólio numerado pela pesquisa: (1).

Notas MA: a lápis preto: correção a acentos agudo e circunflexo em "pra" e "pro": "prá" no lugar de "pra" e "pro" no lugar de "prô". 
126. Nordestinas II; poesia (MAm)

[Natal, ant. 26 ago. 1926]

Datiloscrito, cópia carbono roxo; papel branco, pautado no anverso; 1 folha; 27,2/ $27,3 \times 21 \mathrm{~cm}$; vincos; sinais de fungo; manchas de carbono; marca de clipe na margem superior; ferrugem de clipe no verso; escrita no anverso; rasuras a máquina e a tinta preta; assinatura a tinta preta: "Jorge Fernandes"; fólio numerado pela pesquisa: (1).

Notas da pesquisa:

1. Ms na vertente Mário de Andrade mentor.

2. Local e data atestados com base na carta de JF a MA, de Natal em 26 de agosto de 1926, na qual está: "Como V. tem me pedido sempre lhe envio | alguns dos meus desconxavados poemas. Junto mais alguns poemas e | espero merecer a sua apreciação muito valiosa pra mim. CANÇÃO AO | SOL não sei se lhe impressionará [...]. NORDESTINA é a mão ferida nas queimas do Cardeiro pra matar a fome do gado [...]"(Ref.: série Correspondência Mário de Andrade - sub-série Correspondência passiva; MA-CCPL, no 2699)

3. Canção ao sol permaneceu inédito, possivelmente.

4. Nordestinas (Avoetes) e Nordestinas II foram publicados, com o título "Avoêtes..." e "Mão nordestina" em Livro de poemas. (ed. cit.) (V. MA-MOE, 121, notas 2-3,6-7).

Estudo genético:

1. O ms apresenta-se em uma única versão, A, que mostra em Canção ao sol 1 etapa na escritura e, em Nordestinas, Nordestinas II, 2 etapas na escritura: a-a $a_{1}$ : a: datiloscrito completo; $\mathrm{a}_{1}$ : rasuras e a tinta preta.

2. Versão A confrontada com a versão B em Livro de poemas (ed. cit.), mostra variantes entre ambas versões.

\section{MA - MOE, 127}

\section{FERNANDES, Jorge (1887-1957)}

127. "Primeira chama de vida - rubro sangue..."; poesia (MAm)

[Natal, 1926 ?]

Datiloscrito cópia, carbono roxo; papel branco; 1 folha; 26,9 x 20,6/ 20,9 cm; vincos; sinais de fungo; marca de clipe na borda superior à esquerda; mancha de carbono; escrita no anverso; dedicatória: "Ao primeiro soldado brasileiro | morto em combate defendendo o | Brasil:"; assinatura a tinta preta: "Jorge Fernandes"; rasura a máquina; fólio numerado pela pesquisa: (1).

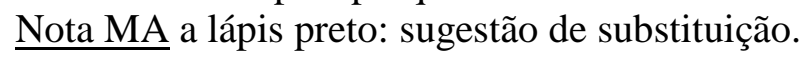

Notas da pesquisa:

1. Ms na vertente Mário de Andrade mentor.

2. O poema permaneceu inédito, ao que se sabe. 
3. Os ms de JF chegavam a MA junto de cartas do próprio escritor e de Luís da Câmara Cascudo, as quais, na maioria das vezes, não mencionavam os títulos dos poemas enviados, o que impediu a pesquisa de datar com segurança. (V. MA-MOE, 121, notas 2-3,6-7).

Estudo genético:

1. O ms apresenta-se em uma única versão, $A$, que mostra 2 etapas na escritura: $a-a_{1}$ :

a: datiloscrito completo;

$\mathrm{a}_{1}$ : rasura a máquina.

\section{MA - MOE, 128}

FERNANDES, Jorge (1887-1957)

128. Sertão; poesia (MAm)

[Natal, 1926 ?]

Datiloscrito, cópia carbono roxo; título em autógrafo a tinta preta; papel branco, pautado no anverso; 1 folha; 27,2/ 27,3 x $21 \mathrm{~cm}$; borda superior irregular; vincos; sinais de fungo; manchas de carbono; marcas de amassado; escrita no anverso; rasuras a máquina; fólio numerado pela pesquisa: (1).

Notas Luís da Câmara Cascudo em autógrafo a tinta preta: Título: "Sertão"; correção na grafia de palavras e indicação de autoria na margem inferior: "Jorge" e palavra riscada na margem superior: "stss".

Notas da pesquisa:

1. Ms na vertente Mário de Andrade mentor.

2. O poema permaneceu inédito, provavelmente.

3. V. MA-MOE, 127 , nota 3.

Estudo genético:

1. O ms apresenta em uma única versão, $A$, que mostra 3 etapas na escritura: $a-a_{1}-a_{2}$ :

a: datiloscrito completo;

$\mathrm{a}_{1}$ : rasuras a máquina;

$\mathrm{a}_{2}$ : correções por Câmara Cascudo.

\section{MA-MOE, 129}

FERREIRA, Ascenso (Ascenso Carneiro Gonçalves Ferreira 1895-1965)

129. A cabra cabriola; A casa-grande de Megahype; Branquinha; Graf Zeppelin; Martello; Martello; Mula de padre; Mysticismo n" 2; Nordeste; Noturno; O "Verde"; poesia (MAd)

[Recife, ant. 1939]

Autógrafo a tinta preta; papel branco, pautado; 12 folhas; 33,0 x 21,9/22,2 cm, com variações em mm na largura; borda esquerda recortada; vincos; sinais de fungo; f. 1, 
11: furo; f. 5-6: canto superior esquerdo: recortado; f. 5-6: rasgamentos na margem superior à esquerda; f. 7-10, 12: 2 furos; f. 10: última palavra do poema borrada; escrita no anverso e no verso; rasuras: a tinta preta; fólios numerados pela pesquisa: (1)-(1) (2). Notas MA.

A casa-grande de Megahype:

Notas MA na margem superior: a lápis vermelho: sinal de "x", a lápis preto: "escolhido".

\section{Branquinha:}

Dedicatória: "Pra Manuel Bandeira"; páginas numeradas: a lápis preto: 2-3.

Notas MA: a lápis vermelho: pequeno círculo; a lápis preto: "escolhido".

Graf Zeppelin:

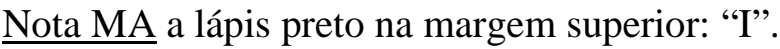

Martello (f. 7):

Notas MA na margem superior: a lápis vermelho: pequeno círculo e sinal de " $x$ ", a lápis preto: 3 sinais de "x" e observação: "escolhido".

Noturno:

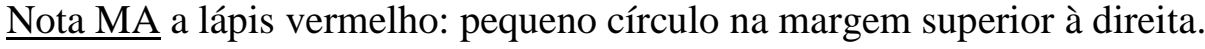

$O$ "Verde":

Nota MA na margem superior: a lápis preto: 3 sinais de " $x$ " e observação: "escolhido", a lápis vermelho: sinal de "x".

Notas da pesquisa:

1. Ms na vertente Mário de Andrade no diálogo interpares.

2. Local e data dos poemas A cabra cabriola, A casa-grande de Megahype, Branquinha, Graf Zeppelin, Mula de padre, Mysticismo no 2, Nordeste, Noturno e O "Verde" atestados com base no ano da publicação deles em Canna Caianna (Recife, Empreza Diario da Manhã, 1939), obra com exemplar na biblioteca de MA com a dedicatória: "A Manoel Bandeira | e | Mário de Andrade | Ascenso Ferreira | Recife, 20-9-939".

3. Em carta de $1^{\circ}$ de maio de 1928 , AF pede a MA opinião sobre os poemas Mula do padre e Trem de Alagoas. Não foi possível atestar se o escritor se refere ao mesmo poema enviado no ms acima registrado. (Ref. cruzada: série Correspondência Mário de Andrade - sub-série Correspondência passiva; MA-C-CPL, $\mathrm{n}^{\circ}$ 2900).

4. Sobre o trabalho do poeta pernambucano, MA publicou o artigo "Ritmo novo", no Diário Nacional de São Paulo, em 1927.

Estudo genético:

1. Martello apresenta-se em 3 versões: A, B e C. As versões A, Martello (f. 6), e B, Martello (f. 7), estão acima registradas. A análise documentária da versão C está neste catálogo: MA-MOE, 130. Há variantes entre as 3 versões. 
2. A versão A Martello mostra 2 etapas na escritura: a-a : $^{2}$

a: autógrafo completo;

$\mathrm{a}_{1}$ : rasuras a tinta preta.

3. A versão B Martello mostra 2 etapas na escritura: $b-b_{1}$ :

b: autógrafo completo;

$\mathrm{b}_{1}$ : rasuras a tinta preta.

4. Os demais poemas apresentam-se em uma única versão, A.

5. A cabra cabriola, A casa-grande de Megahype, Graf Zeppelin, Martello, Mula de padre, Mysticismo $n^{\circ}$ 2, Nordeste, Noturno, $O$ "Verde" mostram 1 etapa na escritura.

6. Branquinha mostra 2 etapas na escritura: $\mathrm{a}-\mathrm{a}_{1}$ :

a: autógrafo completo;

$\mathrm{a}_{1}$ : rasuras a tinta preta.

7. Versão A de A cabra cabriola; A casa-grande de Megahype; Branquinha; Graf Zeppelin; Mula de padre; Mysticismo $n^{o}$ 2; Nordeste; Noturno; O "Verde" confrontada com a versão B em Canna Caianna (ed. cit.). Há variantes entre as versões.

8. Versão A e B de Martello com variantes em relação a versão C

\section{MA-MOE, 130}

FERREIRA, Ascenso (1895-1965)

130. Martello; poesia (MAd)

[Recife], s/ data

Autógrafo a tinta preta; papel branco, pautado; 1 folha; $33,1 \times 21,8 / 22,1 \mathrm{~cm}$; borda esquerda recortada; vincos; sinais de fungo; escrita no anverso e no verso; assinatura: "Ascenso"; rasuras a tinta preta; fólio numerado pela pesquisa: (1).

Notas da pesquisa:

1. Ms na vertente Mário de Andrade no diálogo interpares.

2. O poema permaneceu inédito, ao que se pode avaliar.

\section{Estudo genético}

1. Martello apresenta-se em 3 versões: A, B e C. A versão C está acima registrada. A análise documentária das versões A e B está neste catálogo: MA-MOE, 129. Há variantes entre as 3 versões.

2. A versão $\mathrm{C}$ de Martello mostra 2 etapas na escritura: $\mathrm{c}-\mathrm{c}_{1}$ :

c: autógrafo completo;

$\mathrm{c}_{1}$ : rasuras a tinta preta.

3. Há variantes que mostram o texto mais distante da versão impressa, por isso foi considerada versão A. 


\section{MA-MOE, 131}

FERREIRA, Ascenso (1895-1965)

131. Mulata Sarará; poesia (MAd)

[Recife], s/ data

Datiloscrito, cópia carbono roxo; papel beje; 2 folhas; f. 1: 26,8/ 27,5 x 20,6/20,8 cm, f. 2: $27,4 / 26,7$ x 20,5/20,8 cm; bordas esquerda e direita recortadas; vinco; sinais de fungo; f. 1-2: 2 rasgamentos na borda esquerda; escrita no anverso; f. 2 numerada pelo escritor: 2; rasuras a máquina; fólios numerados pela pesquisa: (1)-(2).

Notas da pesquisa:

1. Ms na vertente Mário de Andrade no diálogo interpares.

2. Poema publicado em Canna Caianna (ed. cit.) (V. MA-MOE, 129, notas 2, 4).

\section{Estudo genético}

1. O ms apresenta-se em uma única versão A, que mostra 2 etapa na escritura: a-a $a_{1}$ : a: datiloscrito completo; $\mathrm{a}_{1}$ : rasuras a máquina.

2. Versão A confrontada com a versão B, em Canna Caianna (ed. cit), apresenta poucas variantes.

\section{MA-MOE, 132}

FERREIRA, Ascenso (1895-1965)

132. Historia de Trancoso; poesia (MAd)

[Recife], s/ data

Datiloscrito original, fita preta; papel branco, filigrana "VENCEDOR EXTRA STRONG"; 1 folha; 25,0/ 32,6 cm; parte inferior do papel à esquerda recortada; vincos, sinais de fungo; escrita no anverso; rasuras a tinta preta; fólio numerado pela pesquisa: (1). Nota AF: “- Impressões de uma pessoa | que não-conhecende (que) encontrou pela $\mid 1^{\mathrm{a}}$ vez e a noite, um moto- | clite | Que tal?- | Ascenso".

Notas da pesquisa:

1. Ms na vertente Mário de Andrade no diálogo interpares.

2. O poema permaneceu inédito.

\section{Estudo genético}

1. O ms apresenta-se em uma única versão $A$, que mostra 2 etapas na escritura: a-a $a_{1}$ a: datiloscrito completo;

$\mathrm{a}_{1}$ : rasuras a tinta preta. 
MA-MOE, 133

FERREIRA, Ascenso (1895-1965)

133. Os engenhos de minha terra; poesia (MAd)

[Recife], s/ data

Datiloscrito original, fita preta; título em autógrafo a tinta preta; papel branco; 1 folha; 32,9 x 21,7/ 22,1 cm; borda esquerda recortada; vincos; sinais de fungo; furo na margem superior esquerda; mancha de carbono roxo; escrita no anverso e no verso; rasuras a tinta preta; fólio numerado pela pesquisa: (1).

Notas da pesquisa:

1. Ms na vertente Mário de Andrade no diálogo interpares.

2. Poema publicado em Canna Caianna (ed. cit.) (V. MA-MOE, 129, notas 2, 4).

Estudo genético:

1. Ms apresenta-se em uma única versão $A$, que mostra 2 etapas na escritura: a-a $a_{1}$ : a: datiloscrito completo;

$\mathrm{a}_{1}$ : rasuras a tinta preta,

2. Versão A confrontada com a versão B, em Canna Caianna (ed. cit), exibe variantes.

\section{MA-MOE, 134}

FERREIRA, Ascenso (1895-1965)

134. Camelots; poesia (MAd)

[Recife], s/ data

Datiloscrito original, fita preta; papel branco; 1 folha; 29,5/ 29,9 x 21,8 cm; vincos; sinais de fungo; escrita no anverso; assinatura: a tinta preta: "Ascenso Ferreira"; rasuras a máquina e a tinta preta; fólio numerado pela pesquisa: (1). Nota AF a máquina: "Nota: Deixa de fazer parte do livro Catimbó por não ter feição abso- | lutamente local, isto é, bazileira. | O livro "Catimbó" é um livro de estillisação de motivos populares | brazileiros, e, mui particularmente, do Nordeste. |O autor".

Nota MA a lápis preto no verso: "Ascenço | Ferreira".

Notas da pesquisa:

1. Ms na vertente Mário de Andrade no diálogo interpares.

2. O poema permaneceu inédito em livro, ao que se pode inferir.

\section{Estudo genético}

1. O ms apresenta-se em uma única versão $A$, que mostra 3 etapas na escritura: $a-a_{1}-a_{2}$ : a: datiloscrito completo;

$\mathrm{a}_{1}$ : rasuras a máquina;

$a_{2}$ : rasuras a tinta preta. 


\section{MA-MOE, 135}

FERREIRA, Ascenso (1895-1965)

135. Pagamento; poesia (MAd)

[Recife], s/ data

Datiloscrito, cópia carbono preto; papel branco; 2 folhas; f. 1: 32,3/ 30,3 x 21,9/ 19,7 cm, f. $2: 32,2$ x 22,0; f. 1: canto superior esquerdo rasgado; f. 2: canto superior esquerdo com resto de cola onde estava grudada a f. 1 ; manchas de tinta; f. 1: escrita no anverso e no verso, f. 2: escrita no anverso; f. 2: página numerada pelo escritor: 3; rasuras a máquina e a tinta preta; fólios numerados pelapesquisa: (1)-(2). Nota AF a tinta preta na f. 2: "Como Voce vê a machina está uma desgra- | ça! Prefiro escrever a mão.”.

Nota MA a lápis preto na f. 1: comentário: "Trocar o $\langle\langle$ eu $\rangle>$ do penultimo | verso. | Não incluir o documento | popular."

Notas da pesquisa:

1. Ms na vertente Mário de Andrade no diálogo interpares.

2. O poema permaneceu inédito em livro, ao que se pode inferir.

\section{Estudo genético}

1. O ms apresenta-se em uma única versão $A$, que mostra 3 etapas na escritura: $a-a_{1}-a_{2}$ : a: autógrafo completo;

$\mathrm{a}_{1}$ : rasuras a máquina;

$\mathrm{a}_{2}$ : rasuras a tinta preta.

\section{MA - MOE, 136}

\section{FERREIRA, Stella Gris}

136. Bolo de farofa; Bolo de massa enxombrada; Bolo de rolo; Bolo brazileiro; Bolo de macacheira; Bolo de milho; Bolo gordo; Brôa de côco; Bolo 13 de maio; Pé de moleque; Bolo de sinhá Fulô; Bolo de massa enxonmbrada; Bolo de mãe Benta; Bolo de sinhá Chiquinha; Broinhass de milho; Pudim de noiva; Sopa de frade; Doce de amor; Suspiros de amor; Bolinhos legalistas; Quem come gosta; Não chega; Bolo de S. João; Pudim de macaxeira; Engorda marido; Bolo de inhame; Amarra marido; Bolinhos do céo; Bolinho sem vergonha; Bolo Guararapes; Biscoitos de manteiga; Baba de moça; Lingua de moça; Pudim de tapioca; Pudim de D. Luiza; Bom bucado de côco; Beijos de cabocla; receitas de culinária (MAc)

[Recife, ant. 24 set. 1930]

Autógrafo a tinta preta; papel branco; 15 folhas; f. 1-12, 14-15: 15,3/ 15,5 x 21,9 cm, com variações em mm, f. 13: 10,7/ 15,5 x 22,0 cm; f. 1-6, 8-12, 14-15: borda inferior recortada; f. 7, 13: bordas superior e inferior recortadas; f. 14: risco de tinta preta no verso; sinais de fungo; escrita no anverso e no verso; f. 1-15: furos para arquivamento; rasura a tinta preta; fólios numerados pela pesquisa: (1)-(1) (5).

Nota MA a lápis preto: f. 2: "Escolher as | mais interes- | santes". 
Broinhas de milho:

Nota SGF a tinta preta: f. 7: "Gostosissimas!...".

Biscoitos de manteiga:

Nota SGF a tinta preta: f. 13"saboros!...".

Bom bucado de côco:

Nota SGF a tinta preta: "Gostosos.".

Anexos:

1) Bilhete de SGF a MA; [Recife, ant. 24 set. 1930]; assinado: "Stella"; forma de tratamento: "Mario"; autógrafo a tinta preta; papel beje, pautado; 1 folha; 11,6/ $12,4 \times 21,9 / 22,0 \mathrm{~cm}$; folha rasgada em três pedaços; borda inferior rasgada; sinais de fungo; escrita no anverso; fólio numerado pela pesquisa: (1. Conteúdo: "Vão receitas de bôlo. Não sei se ellas estão | bem explicadas. Alguma que você não coseguir | comprehender mande dizer. Não pense que isso | me aborrece; aqui estou arranjando outras, e | tambem de comidas. Pode me escrever $\mid$ tantas vezes queira e pedindo o que você sonhar".

2) Envelope: destinatário: "Sr. | Mario de Andrade"; remetente: "Stella Gris"; carimbo dapostagem: "Recife" 24 set. 1930; autógrafo a tinta preta; papel pardo; 15,3 x 23,7/ 23,9 cm; 2 selos; 3 carimbos do correio; borda direita rasgada; cartão colado com identificação do documento na biblioteca MA: "B/ VI/ e-op. 26/ 145"; fólio numerado pela pesquisa: (1).

Notas MA: a lápis roxo no anverso e no verso: "Receitas".

Notas da pesquisa:

1. Ms na vertente Mário de Andrade colecionador.

2. Local e data atestados com base no carimbo do Correios no envelope.

3. No Fichário Analítico da série Manuscritos Mário de Andrade, no arquivo do escritor, estão outras receitas recolhidas por ele. Sobre o assunto, Flávia Camargo Toni escreveu "Doces para uma festa de 110 anos", na revista D. O. Leitura, n. 10, ano 21, São Paulo, Imprensa Oficial do Estado, out. 2003.

Estudo genético:

1. O ms apresenta-se em uma única versão, A, que mostra nas receitas Bolo de farofa, Bolo brazileiro, Bolo de milho, Bolo 13 de maio, Pé de moleque, Broinhas de milho, Pudim de noiva, Não chega, Bolinho sem vergonha, Bolo Guararapes, Lingua de moça, Pudim de tapioca, Bom bucado de côco 1 etapa na escrita, e nas demais receitas 2 etapas na escritura: $\mathrm{a}-\mathrm{a}_{1}$ :

a: autógrafo completo;

$\mathrm{a}_{1}$ : rasuras a tinta preta. 
MA - MOE, 137

\section{FERREIRA, Stella Gris}

137. Historia de Maria Borralheira; folclore (MAc)

[Recife, post. fev. 1935]

Autógrafo a tinta azul; papel branco, pautado no anverso; 6 folhas; 26,3/ 26,4 x 17,9/ $18,2 \mathrm{~cm}$, com variação em mm na largura; f. 1-5: borda esquerda recortada; f. 6: borda esquerda picotada; vincos; sinais de fungo; f. 1: furo na borda direita; f. 3: manchada de tinta azul no verso; escrita no anverso; folhas numeradas pela escritora: II-VI; rasuras a tinta azul; fólios numerados pela pesquisa: (1)-(6).

Nota MA a lápis preto: f. 1: "(Versão pernambucana do | Recife. Contada por Stella | Gris Ferreira em 1935, tal | como a escutou na infância) | MA.".

\section{Notas da pesquisa:}

1. Ms na vertente Mário de Andrade colecionador.

2. Data e local atestados com base na carta de SGF a MA, de [Recife, posterior a fevereiro de 1935], na qual se lê: "Vae a historia de Maria Borralheira | tal qual me contavam quando eu era pequena. | Não lhe escrevi e não mandei logo que | você pediu porque você nem calculas | os meus atropelos. [...] Estou morta | de sonno, terminei a Maria | Borralheira, já dormindo por | cima do papel. São 10 horas | da noite, [...]". (Ref.: série Correspondência Mário de Andrade - sub-série Correspondência passiva; MA-C-CPL, $\left.n^{\circ} 3005\right)$

Estudo genético:

1. O ms apresenta-se em uma única versão, $A$, que mostra 2 etapas na escritura: a-a $a_{1}$ : a: autógrafo completo;

$\mathrm{a}_{1}$ : rasuras a tinta azul.

\section{MA - MOE, 138}

FIGUEIREDO, Guilherme (Guilherme de Oliveira Figueiredo 1915-1997)

138. Trinta anos sem paisagem; romance (MAm)

[Rio de Janeiro, ant. jun. 1939]

Datiloscrito original fita preta; autógrafo a tinta preta; cartolina verde: f. 1; papel branco: f. 2-140, timbrado: "PROCURADORIA JUDICIAL DO MUNICIPIO": f. 3$38,40-41,52-58,62-70,83-90,94-96,104-105,112-115,121-125,131-140$, margens verticais azuis: f. 3-60, 62-69, 81-110, 112-140; f. 1: carimbo no verso: "CASA ROSENHAIN | Rua São Bento, 385 - S. PAULO" e marcação a lápis do preço do caderno: " $\$ 600 " ; ~ 140$ folhas; f. 1: 30,9 x 22,0/ 22,5 cm, f. 2: 30,3/ 30,4 x 18,8/ 19,4 cm, f. 3-140: 32,2 x 21,9 cm, com variações em mm; f. 1: cantos superior e inferior direito arredondados, borda esquerda recortada e sinais de amassado; f. 2: rasgamentos nas bordas; f, 6, 18, 58: furo da borda inferior à direita; f. 27: rasgamento na margem superior à direita; f. 61: rasgamentos na borda esquerda; pequenos rasgamentos nas bordas; vincos; sinais de fungo; escrita no verso; f. 13, 67: 
escrita no anverso e no verso; f. 1: capa: com autoria a lápis preto: "Guilherme | Figueiredo", título a lápis vermelho: "TRINTA ANOS | SEM PAISAGEM", e a tinta preta: "CIRANDA, CIRANDINHA..."; rasuras a máquina, a tinta preta: no anverso e no verso, e a lápis preto; folhas numeradas pelo escritor a lápis preto: 1-138; fólios numerados pela pesquisa: (1)-(1) (4) (1). Notas GF: a tinta preta; f. 93: "(ver o caderno)". Notas MA a lápis azul: destaque para frases e parágrafos, traços e cruzes na margem esquerda salientando trechos e sugestões de substituição.

\section{Notas da pesquisa:}

1. Ms na vertente Mário de Andrade mentor.

2. Na biblioteca de MA estão dois exemplares do livro Trinta anos sem paisagem, publicado em 1939 (Rio de Janeiro, Livraria José Olympio Editora). Ambos possuem dedicatória de GF. Com base na primeira dedicatória, foi atestada a data do ms desse romance: "Ah! Mario de An- | drade! Insulta-me, | mas acredita na | minha admiração. | de | Guilherme | Rio, junho, 39.”; o exemplar em questão recebeu notas de leitura a lápis preto, Notas MA. No segundo exemplar está a dedicatória: "Para o Mario de | Andrade, com um | abraço e a reinci- | dência de | Guuilherme | Rio, 1941"; o volume acompanhou a carta de GF a MA, do Rio de Janeiro, 13 de dezembro de 1941, na qual se lê: "Estou te escrevendo na maior encabulação deste mundo. No minuto em que | recebi as "Poesias", me lembrei que o teu secretario me escreveu, há tempos, pe- | dindo um miserável exemplar do "30 anos", que até hoje eu não enviei - mas que es- | tará aí no mesmo instante em que esta chegar. Que verginha!". (Ref.: série Correspondência Mário de Andrade - sub-série Correspondência passiva; MA-C-CPL, $\mathrm{n}^{\circ}$ 3038). Como se sabe, MA bibliófilo preferia não escrever nas margens (nem separar os cadernos com espátula) dos livros que recebia com dedicatória. Adquiria um segundo exemplar para, nele trabalhar à vontade. Por essa razão, em sua biblioteca há muitos livros de seus correspondentes em duplicata.

3. Na série Correspondência Mário de Andrade, no IEB-USP, não há carta de GF que comprove o envio do ms.

4. O ms não foi passado a limpo com a finalidade de ser entregue a MA; as rasuras mostram o escritor no momento da elaboração do texto. $\mathrm{O}$ ms pode ter sido enviado a MA depois da publicação do livro, como fizera, por exemplo, Antonio de Alcantara Machado com o seu Brás, Bexiga e Barra Funda (V. MA-MOE, 202).

5. Em carta do Rio de Janeiro em 3 de agosto de 1939 GF escreveu a MA: "Caro mestre: | Primeiramente, os meus agradecimentos pe- | la atenção que deu ao '30 anos sem paisagem', alta | prova de sua generosidade. [...] Seguirei a risca suas observações, pode crer." (Ref.: série Correspondência Mário de Andrade - sub-série Correspondência passiva; MA-C-CPL, $\mathrm{n}^{\mathbf{0}}$ 3031).

\section{Estudo genético:}

1. O ms apresenta-se em uma única versão, A, que mostra 4 etapas na escritura: $a-a_{1}-a_{2}-a_{3}$ : a: datiloscrito completo;

$\mathrm{a}_{1}$ : rasuras a máquina;

$\mathrm{a}_{2}-\mathrm{a}_{3}$ : rasuras a tinta preta e a lápis preto, sem possibilidade de identificar a ordem dessas etapas.

2. Versão A confrontada com a versão B: Trinta anos sem paisagem (ed. cit.), mostra variantes. 
MA - MOE, 139

FIGUEIREDO, Guilherme (Guilherme de Oliveira Figueiredo 1915-1997)

139. [Rondinella]; conto (MAm)

[Rio de Janeiro, ant. out. 1943]

Autógrafo a tinta preta; papel beje; 35 folhas; 37,9 x 14,7 cm; vincos; sinais de fungo; f. 12: rasgamento diagonal do canto inferior esquerdo; f. 21: rasgamentos na borda superior; f. 24: rasgamento na parte central da folha; f. 26: rasgamento na borda direita; folhas numeradas pelo escritor: 2-9; escrita no anverso; f. 32: escrita no anverso e no verso; rasuras a tinta preta; fólios numerados pela pesquisa: (1)-(3) (5).

Notas da pesquisa:

1. Ms enquadra-se na vertente Mário de Andrade mentor.

2. Título atestado pelo confronto do $\mathrm{ms}$ com o livro Rondinella e outras histórias, (Empresa Gráfica O Cruzeiro S. A. Rio de Janeiro, 1943).

3. Data e local atestados com base na edição e na dedicatória do exemplar de Rondinella e outras histórias, anotado a lápis, que MA preservou em sua biblioteca: "Mario. | Só hoje tivemos noticia | de que foi mesmo no dia | 9. Nem mesmo telegrama, | uma vergonha... E apro- | veitamos o pretexto para | lhe inflingir Rondinella, | com coração de amizade | de Alba e | Guilherme. | Rio - outubro - 1943”.

Estudo genético:

1. Há 2 versões de Rondinella no arquivo MA. A acima registrada foi considerada pela pesquisa versão A. (V. análise documentária da versão B: MA-MOE, 140).

2. A versão A mostra 2 etapas na escritura: $a-a_{1}$ : a: autógrafo completo; $\mathrm{a}_{1}$ : rasuras a tinta preta.

3. Versão A confrontada com as versões B e C, Rondinella e outras histórias (ed. cit.). Há variantes entre as três versões.

\section{MA - MOE, 140}

FIGUEIREDO, Guilherme (Guilherme de Oliveira Figueiredo 1915-1997)

140. [Rondinella]; conto (MAm)

[Rio de Janeiro, ant. out. 1943]

Datiloscrito, cópia carbono preto: f. 1-12, 19-36, cópia carbono azul: f. 13-18, 37-39; autógrafo a tinta preta: f. 40-51; papel beje: f. 1-36, 40-51; papel verde: f. 37-39; 51 folhas; f. 1-2, 4-36: 37,8/ 37,9 x 14,9 cm; f. 3: 35,1 x 14,9 cm, f. 37-39: 38,2/ 38,5 x 14,8/ 14,9 cm; f. 40-51: 37,7 x 15,0/ 15,1 cm, com variações em mm; f. 37-39: borda inferior recortada; vincos; sinais de fungo; pequenos rasgamentos nas bordas; f. 28 : rasgamento na borda superior à esquerda; f. 46: canto superior direito rasgado; f. 50: rasgamento no canto inferior; perfurações de inseto; f. 1-4, 27: tira de papel colada no verso para sanar rasgamento; folhas numeradas pelo escritor: a máquina: f. 2-39, a 
tinta preta: f. 40-51; f. 6: 2 desenhos a lápis preto no verso; escrita no anverso; rasuras a máquina, a tinta preta e a lápis preto; fólios numerados pela pesquisa: (1)-(5) (1).

Notas da pesquisa:

1. Ms na vertente Mário de Andrade mentor.

2. Título atestado pelo confronto do $\mathrm{ms}$ com o livro Rondinella e outras histórias, Empresa Gráfica "O Cruzeiro" S. A. Rio de Janeiro, 1943.

3. Data e local atestados com base na edição e na dedicatória do exemplar de Rondinella e outras histórias, anotado a lápis, que MA preservou em sua biblioteca: "Mario. | Só hoje tivemos noticia | de que foi mesmo no dia | 9. Nem mesmo telegrama, | uma vergonha... E apro- | veitamos o pretexto para | lhe inflingir Rondinella, | com coração de amizade | de Alba e | Guilherme. | Rio - outubro - 1943”.

Estudo genético:

1. Há 2 versões de Rondinella no arquivo MA. Esta foi considerada B pela pesquisa (V. análise documentária da versão A: MA - MOE, 139).

2. A versão B mostra 6 etapas na escritura: $a-a_{1}-a_{2}-a_{3}-a_{4}-a_{5}$ :

a-a $a_{1}$ : datiloscrito cópia carbono preto e caborno azul, alternadamente;

$\mathrm{a}_{2}$ : rasuras a máquina;

$\mathrm{a}_{3}$ : autógrafo a tinta preta;

$\mathrm{a}_{4}$ : rasuras a tinta preta;

as: rasura a lápis.

3. Versão B confrontada com as versões A e C, em Rondinella e outras histórias (ed. cit.). Há variantes entre as três versões.

\section{MA - MOE, 141}

FIGUEIREDO, Guilherme (Guilherme de Oliveira Figueiredo 1915-1997)

141. Lady Godiva; teatro (MAm)

[Rio de Janeiro, ant. 3 fev. 1944]

Datiloscrito, cópia carbono preto; papel seda, branco, filigrana: f. 16-19, 23, 27-31: "SOBERANO - 500"; 34 folhas; 33,1 x 21,7/ 21,8 cm; sinais de fungo; furos para arquivamento; f. 1: 3 rasgamentos na borda esquerda e ferrugem de clipe na borda superior à esquerda; manchas de carbono; sinais de amassado; folhas numeradas pelo escritor a máquina: 2-33; escrita no anverso; rasuras a lápis e a máquina: em datiloscrito, cópia carbono preto e original, fita preta; f. 1: folha de rosto com título, autoria e epígrafe: "LADY GODIVA | dois atos de | Guilherme Figueiredo | 'Iseut, amie, et vous, Tristan, c'est | votre mort que vous avez bue.' Joseph | Bédier, Tristan et Iseut"; fólios numerados pela pesquisa: (1)-(3) (4).

Notas da pesquisa:

1. Ms na vertente Mário de Andrade mentor.

2. O ms foi encaminhado a MA junto de carta datada do Rio de Janeiro, 3 de fevereiro de 1944, na qual se lê: "Mário: | Estou lhe mandando 'Lady Godiva', | para voc e ler, se 
tiver tempo". (Ref.: série Correspondência Mário de Andrade - sub-série Correspondência passiva; MA-C-CPL, $\mathrm{n}^{\circ}$ 3051)

3. Lady Godiva foi, em 1948, a primeira peça teatral de GF representada, tendo Procópio Ferreira como principal intérprete masculino.

Estudo genético:

1. O ms apresenta-se em uma única versão, A, que mostra 4 etapas na escrituras: $a_{-} a_{1}-a_{2}{ }^{-}$ $\mathrm{a}_{3}$ :

a: datiloscrito completo;

$\mathrm{a}_{1}$ : rasuras a máquina em cópia carbono;

$\mathrm{a}_{3}-\mathrm{a}_{3}$ : rasuras a máquina em datiloscrito original e a lápis, sem possibilidade de identificar a ordem dessas etapas.

MA - MOE, 142

FIGUEIRÓ (Wilson Augusto Figueiredo)

142. A Bailarina; A proveta; Aproximação e súbito afastamento; Assobio em três tempos para a lua; Balanço 1944; Canção-autópsia; Cântico para Maria da Abadia; Cinco poemas para Noel Rosa; Composição para swing; Domingo da datilógrafa; Equilíbrio; Insônia da pensão alegre; Limite noturno; Close-up de uma segundafeira; Máquina portátil; Metabolismo às 7 horas; O escravo; Os complexos; Poema ("Preso aos acontecimentos sem orígem"); Poema número um; Antecipação da espôsa; Lamento fixo; O naufrágio entre jornais; Poema ("Há um pântano de metal fundido"); Rosa; Um corpo sob o jornal; poesia (MAm)

[Belo Horizonte, ant. 16 out. 1944]

Datiloscrito original, fita preta; papel branco, filigrana: f. 1-2,4-9, 11, 14, 19-29, 31$35,37-40,42$; 42 folhas; 32,9 x 22,0 cm, com variações em mm; f. 1-9, 11-14, 19-35, 37-42: irregularidades nas bordas; sinais de fungo; f. 24: pequeno rasgamento na borda inferior à esquerda; f. 30: pequeno rasgamento na margem superior; f. 38: pequenos rasgamentos na borda direita; f. 40: rasgamentos borda inferior e 1 furo; $\mathrm{f}$. 41: 1 furo na borda inferior; escrita no anverso; rasuras: a máquina e a tinta preta; fólio numerado pela pesquisa: (1).

Assobio em três tempos para a lua:

Dedicatória: "para Francisco Iglésias".

Metabolismo às 7 horas:

Dedicatória: "para Carlos Castelo Branco".

Os complexos:

Dedicatória: "para Otto Lara Resende". 
Notas da pesquisa:

1. Ms na vertente Mário de Andrade mentor.

2. Data e local atestados com base na carta de FI a MA, de Belo Horizonte em 16 de outubro de 1944, na qual Figueiró agradece a leitura do crítico: "Gostei, e imensamente, de suas anotações. | Os únicos cortes que tenho sofrido até hoje que me animaram a continuar. Com quase tudo | concordo. [...] É duro, Mário, mas se você ficou chateado perdoe o Figueiró. | Somente você poderia dar a palavra definitiva sobre meu versos e meus vin- $\mid$ te anos, indecisos mais que indecentes. [...] Breve seguirão mais alguns [versos], os que passaram a | existir depois que você saiu. [...] Se você permitir | e aceitar, a série 'close-ups de uma segunda-feira' será o- | ferecida a você". (Ref.: série Correspondência Mário de Andrade - sub-série Correspondência passiva; MA-C-CPL, $\left.n^{\circ} 3069\right)$

3. Os poemas A Bailarina, A proveta, Aproximação e súbito afastamento, Assobio em três tempos para a lua, Balanço 1944, Canção-autópsia, Cinco poemas para Noel Rosa, Composição para swing, Domingo da datológrafa, Equilíbrio, Insônia da pensão alegre, Limite noturno, Close-up de uma segunda-feira, Máquina portátil, Metabolismo às 7 horas, Os complexos, Poema ("Preso aos acontecimentos sem orígem") e Poema número um foram publicados em Mecânica do azul (Belo Horizonte, Editora edifício, 1946).

Estudo genético:

1. O ms apresenta-se em uma única versão, A.

2. A Bailarina; A proveta, Aproximação e súbito afastamento, Assobio em três tempos para a lua, Balanço 1944, Canção-autópsia, Cântico para Maria da Abadia, Cinco poemas para Noel Rosa, Composição para swing, Limite noturno, Metabolismo às 7 horas, Os complexos, Poema ("Preso aos acontecimentos sem orígem"), Poema número um, Antecipação da espôsa mostram 1 etapa na escritura.

3. Domingo da datilógrafa, Equilíbrio, Insônia da pensão alegre, Máquina portátil, $O$ escravo, Lamento fixo, O naufrágio entre jornais, Poema ("Há um pântano de metal fundido"), Um corpo sob o jornal mostram 2 etapas na escritura: a-a

a: datiloscrito completo;

$\mathrm{a}_{2}$ : rasuras a máquina.

4. Close-up de uma segunda-feira mostra 2 etapas na escritura: $\mathrm{a}_{-} \mathrm{a}_{1}$ :

a: datiloscrito completo;

$\mathrm{a}_{1}$ : rasura a tinta preta.

5. Rosa mostra 3 etapas na escritura: $\mathrm{a}-\mathrm{a}_{1}-\mathrm{a}_{2}$ :

a: datiloscrito completo;

$\mathrm{a}_{1}$ : rasura a máquina;

$\mathrm{a}_{2}$ : rasuras a tinta preta.

6. Versão A confrontada com versão B dos poemas: A Bailarina, A proveta (com o título"Quarto de pensão" na versão B), Assobio em três tempos para a lua, Balanço 1944, Canção-autópsia, Cântico para Maria da Abadia (com o título"Cântico" na versão B), Cinco poemas para Noel Rosa, Domingo da datológrafa, Insônia da pensão alegre, Limite noturno, Close-up de uma segunda-feira, Máquina portátil, Metabolismo às 7 horas, $O$ escravo (com o título "Oração para a consciência" na versão B), Os complexos, Poema ("Preso aos acontecimentos sem orígem"), Poema número um mostra variantes. 
MA - MOE, 143

FONSECA, Cleodon

143. Liturgía; O poeta perseguido; Canção do exilado; poesia (MAm)

Recife, [ant. 27 maio 1939]

Datiloscrito, cópia carbono azul; papel branco; 1 folha; 32,5 x 22,1 cm; vincos; sinais de fungo; marca de ferrugem na borda superior à esquerda; letras manchadas; escrita no anverso; autoria e local na margem superior: "Cleodon Fonseca | FACULDADE DE DIREITO | Praça Adolfo Cirne | RECIFE”; rasuras a máquina e a tinta preta; fólio numerado pela pesquisa: (1).

Notas da pesquisa:

1. Ms na vertente Mário de Andrade mentor.

2. Data atestada na carta de CF a MA, de Recife, 27 de maio de 1939, na qual está: "Um conhecido meu, daí do Rio, falou-me no | espirito comunicativo e demicráta do ilustre homem de lêtras. Crendo, | como é certo, ser atendido em uma consulta, pensei, portanto, dirigir-me ao Dr. Mário de Andrade, em quem vejo além de um nome que honra a cultu- | ra nacional, um professor que orienta e que define. [...] Acontece que eu tenho pronto, um livro / de poêmas, sobre os quais já se manifestou a inteligencia grandiosa de | Jorge de Lima. O meu desejo é unicamente este: enviando estes poêmas | pergunto ao ilustre crítico si êles merecem publicação, ou melhor, si | poêmas como estes merecem figurar em um livro". (Ref.: série Correspondência Mário de Andrade sub-série Correspondência passiva; MA-C-CPL, ñ 3108 )

Estudo genético:

1. O ms apresenta-se em uma única versão, A, que mostra 3 etapas na escritura: $a-a_{1}-a_{2}$ : a: datiloscrito completo;

$\mathrm{a}_{1}$ : rasuras a máquina;

$\mathrm{a}_{2}$ : rasuras a tinta preta.

\section{MA - MOE, 144}

\section{FREITAS JÚNIOR, Otávio de}

144. Adalgiza Nery; crítica (MAm)

[Recife, ant. 21 mar. 1940]

Datiloscrito, cópia carbono azul; papel branco; 6 folhas; f. 1-4, 6: 26,1/26,2 x 20,6/20,7 cm, f. 5: 26,1/20,4/20,6; vincos; sinais de fungo; folhas numeradas pelo escritor: 2-6; escrita no anverso; rasuras a máquina; fólios numerados pela pesquisa: (1)-(6).

Notas MA a lápis vermelho: f. 2, 5: trechos sublinhados, sinais de interrogação na margem esquerda, sugestões de substituição e comentários. 
Notas da pesquisa:

1. Ms na vertente Mário de Andrade mentor.

2. Local e data atestados com base na carta de OFJ a MA, de Recife em 21 de março de 1940, na qual se lê: "Hoje lhe mando uma copía do capitulo Adalgisa Nery. Como sempre | quero sua opinião com toda a franqueza". (Ref.: série Correspondência Mário de Andrade - sub-série Correspondência passiva; MA-C-CPL, $n^{\circ}$ 3179)

3. Em 20 de abril de 1940, OFJ responde aos comentários de MA sobre o ensaio: "Acabo de receber sua carta, que me deixou muito satisfeito. Sem- $\mid$ pre esperei de você isto mesmo, esta franqueza, possivelmente um tan- | to rude, mas sobretudo muito amiga. Positivamente você não gostou do | meu 'Adalgisa Nery"'. (Ref.: série Correspondência Mário de Andrade - sub-série Correspondência passiva; MA-C-CPL, no 3180)

4. Na carta do Recife, em 7 de setembro de 1939, OFJ relatara a MA sua intenção de preparar um estudo sobre alguns nomes da poesia brasileira daquele momento: "Tenho estado ocupadissimo com os meus estudos | 'oficiaes'. [...] Por isto pouco tenho avançado no meu | trabalho sobre poesia. | Estou até com vontade de modifical-o. Em | vez de um estudo sobre alguns | poetas novos. Você, Murilo, Adalgisa, Jorge, Manuel Bandeira, Miêta Santiago, Deolindo, | Rossini, Oswald, Juliêta, Vinícius". (Ref.: série Correspondência Mário de Andrade - sub-série Correspondência passiva; MA-C-CPL, $\mathrm{n}^{\mathrm{o}}$ 3175) O primeiro capítulo desse estudo foi remetido a MA (V. MA-MOE, 145).

5. Esse estudo de OFJ permaneceu inédito.

Estudo genético:

1. O ms apresenta-se em uma única versão, A, que mostra 2 etapas na escritura: a-a $a_{1}$ : a: datiloscrito completo;

$\mathrm{a}_{1}$ : rasuras a máquina.

\section{MA - MOE, 145}

\section{FREITAS JÚNIOR, Otávio de}

145. Introdução a um conceito de poesia; crítica (MAm)

[Recife, ant. 20 abril 1940]

Datiloscrito, cópia carbono azul; datiloscrito original, fita vermelha; papel branco; 8 folhas; 27,5 x 20,9 cm; f. 1: canto direito rasgado; f. 3: pequeno rasgamento na borda superior; vinco; sinais de fungo; folhas numeradas pelo escritor: 2-8; escrita no anverso; f. 1: autoria a lápis preto: "OTÁVIO DE FREITAS JR"; rasuras a máquina; fólios numerados pela pesquisa: (1)-8).

Notas MA a lápis vermelho: f. 1-6, 8: traços verticais, pontos de exclamação e de interrogação na margem esquerda destacando trechos; comentários; f. 6: verso sublinhado; f. 8: sugestão de substituição.

Notas da pesquisa:

1. Ms na vertente Mário de Andrade mentor.

2. Data e local atestados com base na carta de OFJ a MA, de Recife em 20 de abril de 1940, na qual se lê: "Estou chateado que você não tenha recebido o primeiro capi- | tulo. Murilo [Miranda] esta semana me escreveu, dizendo que tinha lhe dado o | documento. 
Si isto tivesse acontecido, esclarecería mais minha atitu- | de quanto á poesia . Porque realmente todos os outros capitulo estão | em função do rpimeiro, desde que é no primeiro que dou uma especie de | terminologia que vou usar. Talvez seja mesmo somente isto, o primeiro | capitulo: uma terminologia disfarçada, dos outros". (Ref.: série Correspondência Mário de Andrade - sub-série Correspondência passiva; MA-CCPL, $n^{\circ} 3180$ )

3. OFJ tencionava a publicar um estudo sobre alguns poetas de seu tempo. Enviou a MA dois capítulos: Introdução a um conceito de poesia seria o primeiro, e o segundo intitula-se Adalgiza Nery (V. MA-MOE, 144).

\section{Estudo genético:}

1. O ms apresenta-se em uma única versão, A, que mostra 2 etapas na escritura: a-a $a_{1}$ : a: datiloscrito completo;

$\mathrm{a}_{1}$ : rasuras a máquina.

\section{MA - MOE, 146}

FUSCO, Rosário (1910-1977)

146. Inscrição; poesia (MAm)

[Cataguases], 1925

Datiloscrito original, fita preta; papel branco; 1 folha; 24,2/24,5 x 16,6/16,9 cm; irregularidades nas bordas esquerda, direita e inferior; borda superior picotada vincos; sinais de fungo; escrita no anverso; dedicatória: a máquina: "Pro Henrique"; local, assinatura e nota RF a tinta azul: "1925 | Rosario Fusco. | Acha que vale a pena guardar isso?"; rasuras a tinta azul; fólio numerado pela pesquisa: (1).

Notas da pesquisa:

1. Ms na vertente Mário de Andrade mentor.

2. Nas cartas de RF a MA, na série Correspondência Mário de Andrade, no IEB-USP, encontram-se referências a envio de ms, sem, contudo, mencionar o título.

\section{Estudo genético:}

1. O ms apresenta-se em uma única versão, A, que mostra 2 etapas na escritura: $a-a_{1}$ : a: datiloscrito completo;

$\mathrm{a}_{2}$ : rasuras a tinta azul.

\section{MA - MOE, 147}

FUSCO, Rosário (1910-1977)

147. O poema da minha tristeza; poesia (MAm)

[Cataguases], 1925

Datiloscrito, cópia carbono roxo; papel branco, filigrana; 1 folha; 28,0 x $22,0 \mathrm{~cm}$; rasgamentos na borda direita; vincos; sinais de fungo; manchas de carbono; escrita no 
anverso; data: "1925"; assinatura a tinta azul: "Rosario Fusco"; rasuras a tinta azul; fólio numerado pela pesquisa: (1).

Notas da pesquisa:

1. Ms na vertente Mário de Andrade mentor.

2. O poema da minha tristeza foi publicado em RESENDE, Henrique; FUSCO, Rosário e LOPES, Ascânio. Poemas cronológicos. Cataguazes, Verde Editora, 1928.

3. Na biblioteca de MA está um exemplar do livro com a dedicatória: "Pra você, Mário amigo, | com | a | baita | AMISADE | da | gente | Rosario Fusco | A. Lopes | Henrique de Resende. | Cataguases - Fevo - 928".

4. V. MA-MOE, 146, nota 2, sobre os ms que RF costumava enviar a MA.

Estudo genético:

1. O ms apresenta-se em uma única versão, A, que mostra 2 etapas na escritura: a-a $a_{1}$ : a: datiloscrito completo;

$\mathrm{a}_{1}$ : rasuras a tinta azul.

2. Versão A confrontada com versão B em Poemas cronológicos (ed. cit.), mostra variantes.

\section{MA - MOE, 148}

FUSCO, Rosário (1910-1977)

148. Juiz de Fóra; Desinfectante; Partida; Bello Horizonte; poesia (MAm)

[Cataguases] 4 out. 1927

Poemas no corpo de carta de RF a MA; datada: "4 out. 927"; assinada: "Rosario Fusco"; forma de tratamento: [...] seu Mario."; autógrafo a tinta azul; papel verde, filigrana; 2 folhas; $16,7 \times 12,9 \mathrm{~cm}$; 2 furos para arquivamento; escrita no anverso e no verso; rasuras a tinta azul; fólios numerados pela pesquisa: (1)-(2).

(Ref. cruzada: série Correspondência Mário de Andrade - sub-série Correspondência passiva; MA-C-CPL, n $^{\circ}$ 3225)

Notas da pesquisa:

1. Ms na vertente Mário de Andrade mentor.

2. Na carta RF escreve: "Olha aqui: mando alguns versos novos pra| você. Já mandei elles pro Alcântara tambem. | Não mando os antigos. São cheinhos de | literatura. O Alcântara conhece elles. Pode | perguntar pra elle. [...] Agora os versos:"

Estudo genético:

1. Os poemas Juiz de Fóra, Desinfectante e Bello Horizonte apresentam-se em 2 versões. A pesquisa considerou a versão acima registrada como A. (V. análise documentária da versão B, MA-MOE, 153).

2. Juiz de Fóra, Desinfectante e Partida mostram 1 etapa na escritura, e em Bello Horizonte 2 etapas: a-a $\mathrm{a}_{1}$ :

a: autógrafo completo;

$\mathrm{a}_{1}$ : rasuras a tinta azul. 
MA - MOE, 149

FUSCO, Rosário (1910-1977)

149. Parabola; Chronus; poesia (MAm)

[Cataguases], out. 1927

Autógrafo a tinta preta; duas tiras de papel coladas formando 1 folha; papel branco; 49,9/50,0 x 21,1/12,2 cm; vincos; sinais de fungo; irregularidades na borda superior; escrita no anverso; dedicatória, assinatura e data: "Pra você, Mario | Rosario Fusco. | out. 927"; fólio numerado pela pesquisa: (1). Nota RF a tinta preta na margem inferior: "Insisto (pois agora já é um | desafôro!): quedê a carta? E o livro?".

Nota da pesquisa:

1. Ms na vertente Mário de Andrade mentor.

Estudo genético:

1. O ms apresenta-se em uma única versão, A, que mostra 1 etapa na escritura.

MA - MOE, 150

FUSCO, Rosário (1910-1977)

150. Chroniquêta; poesia (MAm)

[Cataguases], 21 nov. 1927

Autógrafo a tinta azul; papel branco, pautado; 1 folha; 22,7 x 15,3/15,4 cm; borda esquerda recortada; vincos; sinais de fungo; escrita no anverso; margem inferior: bilhete de RF a MA com assinatura: "Rosario Fusco." e data: "21/11/27"; folha numerada pelo escritor: 4; fólio numerado pela pesquisa: (1).

Notas da pesquisa:

1. Ms na vertente Mário de Andrade mentor.

2. Conteúdo do bilhete: "Os outros seguem depois. A macêteação | é um fato, não é Mario - amigo? | Com o coração do seu | Rosario Fusco. | Junto um verso velho de 1925 tambem. | Escreva se gostar. E se não gostar escreva | assim mesmo e me mande elle que não | tenho copia do dito. | 21/11/27". É possível que MA tenha devolvido o ms, cujo título não é acusado neste documento.

Estudo genético:

1. Chroniquêta apresenta-se em duas versões. A versão acima registrada foi considerada A pela pesquisa, e mostra 1 etapa na escritura. (V. análise documentária da versão B, MAMOE, 163). 
MA - MOE, 151

FUSCO, Rosário (1910-1977)

151. Leopoldina; poesia (MAm)

[Cataguases, ant. fev. 1928]

Datiloscrito, cópia carbono roxo; papel branco; 1 folha; 27,7 x 21,4/21,5 cm; rasgamentos nas bordas esquerda e direita; vincos; sinais de fungo; escrita no anverso; assinatura a máquina: "ROSARIO FUSCO"; fólio numerado pela pesquisa: (1). Nota RF em autógrafo a tinta azul na margem inferior à esquerda: "confere". Bilhete de RF a MA no verso: autógrafo a tinta azul e a tinta preta: "Ultima hora | Perdoe o mau geito da teimosia: | a carta já saíu? | E quedê o livro? | Apresentação a sua vontade. | Qualquer coisa que v. fizer só tem | que saír batuta."

Notas da pesquisa:

1. Ms na vertente Mário de Andrade mentor.

2. Local e data atestados com base na dedicatória do exemplar de Poemas cronológicos (ed. cit.) na biblioteca MA: "Pra você, Mário amigo, $\mid$ com $\mid$ a $\mid$ baita $\mid$ AMISADE $\mid$ da $\mid$ gente | Rosario Fusco | A. Lopes | Henrique de Resende. | Cataguases - Fevo - 928”. Leopoldina saiu em Poemas cronológicos (ed. cit.).

3. No dia seguinte do envio de Leopoldina, RF remeteu a MA os poemas Desinfectante, Paisagem $n^{o}$ 2, Juiz-de-fóra, Madrigal, Bahia, Bello Horizonte, Rio de Janeiro, Jornal de interior, Sala de gente pobre (V. MA-MOE, 153).

Estudo genético:

1. O ms apresenta-se em uma única versão, A, que mostra 1 etapa na escritura.

\section{MA - MOE, 152}

FUSCO, Rosário (1910-1977)

152. Serão interior; Vila Terêsa; Festa da bandeira; poesia (MAm)

[Cataguases], 1925-1927

Autógrafo a tinta azul; papel branco, filigrana; 3 folhas; 27,7 x 21,4/21,5 cm; vincos; sinais de fungo; escrita no anverso; fólios numerados pela pesquisa: (1)-(3). Notas RF.

Serão interior:

Data, assinatura e título do livro onde o poema seria publicado: "1925 | Rosario Fusco. | (Poemas cronologicos)".

Vila Terêsa:

Data, assinatura e indicação de livro onde o poema seria publicado o poema: "1926 | Rosario Fusco. | (Poemas cronologicos)". 
Festa da bandeira:

Data, assinatura e indicação de livro onde o poema seria publicado o poema: "1927 | Rosario Fusco. | (Poemas cronologicos)".

Notas da pesquisa:

1. Ms na vertente Mário de Andrade mentor.

2. Serão interior e Vila Terêsa foram publicados em Poemas cronológicos que saiu em 1928 e MA recebeu um exemplar autografado (V. MA-MOE, 151, nota 2).

3. As nota RF indicam a intenção de publicar os poemas no livro Poemas cronológicos (ed. cit.).

4. V. MA-MOE, 146, nota 2, sobre os ms que RF costumava enviar a MA.

Estudo genético:

1. O ms apresenta-se em uma única versão, A, que mostra 1 etapa na escritura.

2. Versão A de Serão interior e Vila Terêsa confrontada com versão B em Poemas cronológicos (ed. cit.), apresenta variantes.

\section{MA - MOE, 153}

FUSCO, Rosário (1910-1977)

153. Desinfectante; Paisagem $n^{o} 2$; Juiz-de-fóra; Madrigal; Bahia; Bello Horizonte; Rio de Janeiro; Jornal de interior; Sala de gente pobre; poesia (MAm)

[Cataguases, ant. fev. 1928]

Autógrafo a tinta preta; papel branco, filigrana; 4 folhas; 27,7/27,8 x 21,4/21,5 cm; rasgamentos nas bordas; f. 3: mancha de carbono roxo; vincos; sinais de fungo; f. 1-2: ferrugem de clipe; f. 3: marca de clipe; f. 4: ferrugem de clipe no verso; poemas numerados pelo escritor: 1-9; escrita no anverso; rasuras a tinta preta e a tinta azul; f. 4: bilhete a MA: "O livro [Poemas cronológicos] conterá dez poemas. Estes que aí vão e mais | o Leopoldina que seguiu hontem pra você".; fólios numerados pela pesquisa: (1)-(4).

Notas da pesquisa:

1. Ms na vertente Mário de Andrade mentor.

2. Local e data atestados com base na dedicatória do exemplar de Poemas cronológicos (ed. cit.) na biblioteca MA: "Pra você, Mário amigo, $\mid$ com $\mid$ a $\mid$ baita $\mid$ AMISADE | da | gente | Rosario Fusco | A. Lopes | Henrique de Resende. | Cataguases - Fevo - 928”, livro que incluiu o poema Sala de gente pobre.

3. No bilhete no ms, RF conta ainda a MA que seguiu conselhos de Alcântara Machado e modificou o final do poema Sala de gente pobre.

4. Sobre o ms de Leopoldina, V. MA-MOE, 151.

Estudo genético:

1. O ms apresenta-se em uma única versão, A.

2. Desinfectante, Paisagem $n^{o}$ 2, Juiz-de-fóra, Rio de Janeiro, Jornal de interior e Sala de gente pobre 1 etapa na escritura. 
3. Madrigal mostra 2 etapas na escritura: $\mathrm{a}_{-} \mathrm{a}_{1}$ :

a: autógrafo completo;

$\mathrm{a}_{1}$ : rasura a tinta azul.

4. Bahia e Bello Horizonte mostram 2 etapas na escritura: $\mathrm{a}_{-} \mathrm{a}_{1}$ :

a: autógrafo completo;

$\mathrm{a}_{1}$ : rasura a tinta preta.

MA - MOE, 154

FUSCO, Rosário (1910-1977)

154. Tricromia; Inocencia; Vesperal; Manhan; Legenda; Poema da rua do porão; Caricia; poesia (MAm)

[Cataguases, ant. fev. 1928]

Datiloscrito original, fita preta; papel branco; 7 folhas; 23,7/24,0 x 16,6 cm, com variações em mm; bordas superior, inferior e direita recortadas; f. 1: canto inferior esquerdo amassado; f. 5: canto inferior direito rasgado e mancha de tinta na margem direita; f. 6: canto superior direito rasgado; vincos; sinais de fungo; escrita no anverso; f. 8: assinatura: autógrafo a tinta azul: "Rosario Fusco."; rasuras a máquina e a tinta azul; fólio numerado pela pesquisa: (2).

Tricromia:

Nota MA a lápis preto no final do poema: "Não existe".

Inocencia:

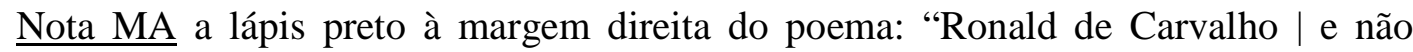
presta".

Vesperal:

Nota MA: a lápis preto no final do poema: "Ronald | e regular".

Manhan:

Nota MA a lápis preto no final do poema: "Nada | não existe".

Legenda:

Folhas numeradas pelo escritor a tinta azul: 1-2.

Notas MA a lápis preto: sugestões de supressão.

Poema da rua do porão:

Dedicatória: "Pro Ascanio"

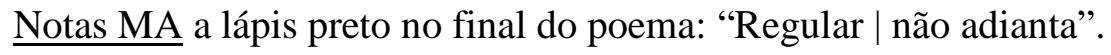

Caricia:

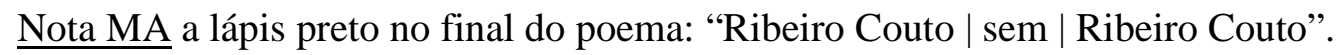


Notas da pesquisa:

1. Ms na vertente Mário de Andrade mentor.

2. Local e data atestados com base na dedicatória do exemplar de Poemas cronológicos (ed. cit.) na biblioteca MA: "Pra você, Mário amigo, $\mid$ com $\mid$ a $\mid$ baita $\mid$ AMISADE | da | gente | Rosario Fusco | A. Lopes | Henrique de Resende. | Cataguases - Fev ${ }^{\circ}-928$ ", livro que inclui Poema da rua do porão.

3. V. MA-MOE, 146, nota 2, sobre os ms que RF costumava enviar a MA.

\section{Estudo genético:}

1. O ms apresenta-se em uma única versão, A, que mostra 3 etapas na escritura: $a-a_{1}-a_{2}$ : a: datiloscrito completo;

$\mathrm{a}_{1}$ : rasuras a máquina; $\mathrm{a}_{2}$ : rasuras a tinta azul.

2. Versão A confrontada com a versão B em poemas cronológicos (ed. cit.), exibe variantes.

\section{MA - MOE, 155}

FUSCO, Rosário (1910-1977)

155. Domingo; poesia (MAm)

[Cataguases, ant. fev. 1928]

Datiloscrito original, fita preta; papel branco; 1 folha; 24,0/24,2 x 20,4/20,5 cm; bordas recortadas; vincos; sinais de fungo; escrita no anverso; rasuras a máquina e a tinta azul; fólio numerado pela pesquisa: (1).

Nota MA a lápis preto: sugestão de substituição e comentário: "Bom".

Notas da pesquisa:

1. Ms na vertente Mário de Andrade mentor.

2. Local e data atestados com base na dedicatória do exemplar de Poemas cronológicos (ed. cit.) na biblioteca MA: "Pra você, Mário amigo, $\mid$ com $\mid$ a $\mid$ baita $\mid$ AMISADE $\mid$ da $\mid$ gente | Rosario Fusco | A. Lopes | Henrique de Resende. | Cataguases - Fev ${ }^{\circ}-928 ”$. neste livro foi publicado o poema no ms.

3. V. MA-MOE, 146, nota 2, sobre os ms que RF costumava enviar a MA.

Estudo genético:

1. O ms apresenta-se em uma única versão, $A$, que mostra 3 etapas na escritura: $a-a_{1}-a_{2}$ : a: datiloscrito completo;

$\mathrm{a}_{1}$ : rasuras a máquina;

$\mathrm{a}_{2}$ : rasuras a tinta azul.

2. Versão A confrontada com versão B em Poemas cronológicos (ed. cit.), apresenta variantes. 
MA - MOE, 156

FUSCO, Rosário (1910-1977)

156. Carta aberta pra Rosa; Ditado da casa caiada; poesia (MAm)

[Cataguases], fev., dez. 1928

Datiloscrito, cópia carbono roxo; papel branco; 2 folhas; 22,6 x $15,4 \mathrm{~cm}$; vincos; sinais de fungo; f. 1: mancha de tinta azul; escrita no anverso; assinaturas: f. 1-2: "Abraços verdes | Rosario", f. 2: "Rosario Fusco."; rasura a tinta azul; fólio numerado pela pesquisa: (2). Notas RF: f. 1: a máquina embaixo do título: "(motivo popular mineiro)". f. 2: bilhete a MA em autógrafo a tinta azul na margem esquerda: "Não vale nada como poesia porém é dum sabor de terra| tipicamente mineiro".

Carta aberta pra Rosa:

Datado: "Dezembro de 1927".

Ditado da casa caiada:

Datado: "Fevereiro de 1928".

Notas da pesquisa:

1. Ms na vertente Mário de Andrade mentor.

2. O poema Carta aberta pra Rosa foi publicado em Fruta de conde (Cataguazes, Verde Editora, 1929), no exemplar de MA estaria a dedicatória: "Ao meu querido Mario com | a promessa de que só cairei | noutra si tiver alguma novidade | pra contar | Fusco | jano de 1929 | Cataguazes".

3. V. MA-MOE, 146, nota 2, sobre os ms que RF costumava enviar a MA.

Estudo genético:

1. O ms apresenta-se em uma única versão, A, que mostra 2 etapas na escritura: a-a ${ }_{1}$ : a: datiloscrito completo;

$\mathrm{a}_{1}$ : rasura a tinta azul.

2. Versão A confrontada com a versão B em Fruta de conde (ed. cit.), exibe variantes.

MA - MOE, 157

FUSCO, Rosário (1910-1977)

157. Desencantação; Rondó do amor escapulido; poesia (MAm)

[Cataguases], fev. / mar. 1928]

Autógrafo a tinta preta; papel branco; 2 folhas; f. 1: 23,9/24,1 x 16,8/17,0 cm, f. 1: 24,2 x 16,6/16,8 cm; irregularidade nas bordas; f. 1: rasgamentos na borda direita; $\mathrm{f}$. 2: rasgamento na bordas direita e esquerda; vincos; sinais de fungo; dois furos para arquivamento; f. 2: mancha de tinta o verso; escrita no anverso; fólios numerados pela pesquisa: (1)-(2). 
Desencantação:

Assinatura e data: "Rosario Fusco. | Fevo 1928".

Rondó do amor escapulido:

Assinatura e data: "Rosario Fusco. | Março de 1928".

Notas da pesquisa:

1. Ms na vertente Mário de Andrade mentor.

2. V. MA-MOE, 146, nota 2, sobre os ms que RF costumava enviar a MA.

Estudo genético:

1. O ms apresenta-se em uma única versão, A, que mostra 1 etapa na escritura.

MA - MOE, 158

FUSCO, Rosário (1910-1977)

158. "O vento palmeia uma valsa no ar!"; Poema; Este verso vai molhado; poesia (MAm) [Cataguases], 16 set. 1928

Datiloscrito, cópia carbono azul; papel branco, filigrana; 4 folhas; 28,4/28,5 x 21,9 cm; borda superior recortada; f. 3: rasgamentos na borda direita; vincos; sinais de fungo; manchas de carbono; folhas numeradas pelo escritor a tinta azul: 1-2; escrita no anverso; f. 2: assinatura a máquina: "Rosario Fusco."; rasuras a máquina; fólios numerados pela pesquisa: (1)-(3). Nota RF. Notas MA; f. 3: bilhetes de RF a MA: a máquina: "Aí vão troços. Fale logo o que acha.", comentários sobre Macunaíma, opinião negativa sobre crônica de T. de A, à qual MA redigiu uma nota à margem inferior: "(Henrique gostou)", observação a respeito de texto que Gastão de Almeida estava a escrever e notícias da revista Verde; a lápis azul à margem esquerda: "Sodade danada de você. deixa de ingratitude / e escreva pelo amor de mim. Meia segue logo"; a lápis vermelho à margem direita: "Verso do para todos | admiravel. Porque não manda | um original assim pra gente, | Mario!".

"O vento palmeia uma valsa no ar!":

Nota RF a tinta azul: f. 2: "esculhambe em regra, conforme promessa. | Corrija o que achar ruím".

Notas MA a lápis preto: correções.

\section{Poema:}

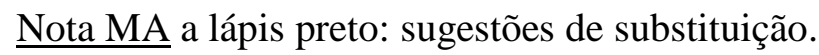

Este verso vai molhado:

Dedicatória: "a Ascanio Lopes".

Notas MA a lápis preto: sugestões de substituição. 
Notas da pesquisa:

1. Ms na vertente Mário de Andrade mentor.

2. Poema foi publicado em Fruta de conde (ed. cit.).

3. MA preservou um exemplar desse livro em sua biblioteca com a dedicatória: "Ao meu querido Mario com | a promessa de que só cairei | noutra si tiver alguma novidade | pra contar | Fusco | jan ${ }^{\circ}$ de 1929 | Cataguazes".

Estudo genético:

1. O ms apresenta-se em uma única versão, A, que mostra 2 etapas na escritura: a-a $a_{1}$ : a: datiloscrito completo; $\mathrm{a}_{1}$ : rasuras a máquina.

2. Versão A de poema confrontada com a versão B em Fruta de conde (ed. cit.), mostra variantes.

MA - MOE, 159

FUSCO, Rosário (1910-1977)

159. "Remate de Males"; crítica (MAm)

Cataguases, 25 dez. 1930

Datiloscrito original, fita azul; papel branco; 3 folhas; f. 1-2: 27,6/27,7 x 22,0/22,1 cm, f. 3: 27,5/27,6 x 21,8/22,2 cm; vincos; sinais de fungo; folhas numeradas pelo escritor: 2-3; escrita no anverso; f. 1: assinatura a máquina: "Rosario Fusco."; f. 3: local e data: "Cataguazes, 25 de dezembro de 1930"; rasuras a máquina e a tinta preta; fólios numerados pela pesquisa: (1)-(3).

Notas da pesquisa:

1. Ms na vertente Mário de Andrade mentor.

2. V. MA-MOE, 146, nota 2, sobre os ms que RF costumava enviar a MA.

Estudo genético:

1. O ms apresenta-se em uma única versão, A, que mostra 3 etapas na escritura: $a-a_{1}-a_{2}$ :

a: datiloscrito completo;

$\mathrm{a}_{1}$ : rasuras a máquina

$\mathrm{a}_{2}$ : rasuras a tinta preta.

MA - MOE, 160

FUSCO, Rosário (1910-1977)

160. Momento vesperal; Quando as fonte emmudecem; Momento; poesia (MAm)

[Cataguases], set., out. 1931

Datiloscrito original, fita azul; papel branco, filigrana: "RUBY-BOND"; 3 folhas; 30,6 x 20,9 cm; f. 1: pequeno rasgamento na margem superior; vincos; sinais de 
fungo; f. 1: manchas de carbono no verso; escrita no anverso; rasuras a máquina e a lápis preto; fólios numerados pela pesquisa: (1)-(3).

Momento vesperal:

Autoria e data na margem inferior: "Rosario Fusco | setembro de 1931".

Quando as fonte emmudecem:

Autoria e data na margem inferior: "Rosario Fusco | setembro de 1931".

Momento:

Autoria e data na margem inferior: "Rosario Fusco | outubro de 1931-".

Notas da pesquisa:

1. Ms na vertente Mário de Andrade mentor.

2. V. MA-MOE, 146, nota 2, sobre os ms que RF costumava enviar a MA.

Estudo genético:

1. O ms apresenta-se em uma única versão, A, que mostra 3 etapas na escritura: $a-a_{1}-a_{2}$ : a: datiloscrito completo;

$\mathrm{a}_{1}$ : rasuras a máquina

$\mathrm{a}_{2}$ : rasuras a lápis.

\section{MA - MOE, 161}

FUSCO, Rosário (1910-1977)

161. Fazenda; poesia (MAm)

[Cataguases], s/ data

Autógrafo a lápis preto; papel branco; 1 folha; 21,9 x $11,7 \mathrm{~cm}$; vincos; sinais de fungo; escrita no anverso; fólio numerado pela pesquisa: (1). Nota RF a lápis: "Fruta de conde".

Notas da pesquisa:

1. Ms na vertente Mário de Andrade mentor.

2. Em Fruta de conde (ed. cit.) há um poema intitulado "Fazenda", de texto diverso ao do ms.

3. Na biblioteca de MA está um exemplar com dedicatória: "Ao meu querido Mario com | a promessa de que só cairei | noutra si tiver alguma novidade | pra contar | Fusco | jano de 1929 | Cataguazes".

4. V. MA-MOE, 146, nota 2, sobre os ms que RF costumava enviar a MA.

Estudo genético:

1. O ms apresenta-se em uma única versão, A, que mostra 1 etapa na escritura. 
MA - MOE, 162

FUSCO, Rosário (1910-1977)

162. Angelus; Chico Feitor; Flôr de samambaia; Foi em oitenta e sete; poesia (MAm)

[Cataguases], s/ data

Datiloscrito original, fita preta; papel branco, carimbo azul: "Rosario Fusco."; 4 folhas; 29,6 x 21,9/22,0 cm; vincos; sinais de fungo; manchas de tinta azul e preta; escrita no anverso; assinatura a tinta preta: "Rosario Fusco"; rasuras a máquina, a tinta preta e azul; fólios numerados pela pesquisa: (1)-(4).

Notas da pesquisa:

1. Ms na vertente Mário de Andrade mentor.

2. V. MA-MOE, 146, nota 2, sobre os ms que RF costumava enviar a MA.

Estudo genético:

1. O ms apresenta-se em uma única versão, A.

2. Flôr de samambaia mostra 1 etapa na escritura.

3. Chico Feitor e Foi em oitenta e sete mostram 2 etapas na escritura: a-a $a_{1}$ : a: datiloscrito completo;

$\mathrm{a}_{1}$ : rasuras a tinta preta.

4. Angelus mostra 3 etapas na escritura: $\mathrm{a}-\mathrm{a}_{1}-\mathrm{a}_{2}$ :

a: datiloscrito completo;

$a_{1}-a_{2}$ : rasuras a tinta preta e azul, sem possibilidade de se identificar a ordem dessas etapas;

5. Foi em oitenta e sete mostra 3 etapas na escritura: $\mathrm{a}-\mathrm{a}_{1}-\mathrm{a}_{2}$ :

a: datiloscrito completo;

$\mathrm{a}_{1}$ : rasuras a máquina;

$\mathrm{a}_{2}$ : rasura a tinta preta.

MA - MOE, 163

FUSCO, Rosário (1910-1977)

163. Elegia; Théoria; Chrôniqueta; Sentimental; Jazz-band; poesia (MAm)

[Cataguases], s/ data

Datiloscrito, cópia carbono roxo; autógrafo a tinta preta; papel branco; 4 folhas; $14,7 / 14,8 \times 11,9 / 12,0 \mathrm{~cm}$; f. 1-2: borda inferior recortada; f. 3-4: borda inferior recortada; sinais de fungo, manchas de carbono; escrita no anverso; assinatura a tinta preta no final de cada poema: "Rosario Fusco."; rasuras a tinta preta; fólios numerados pela pesquisa: (1)-(4). F. 4: bilhete RF a MA: "Quero dedicar um verso pra você. | Escôlha um destes. Se nenhum deles | valer coisa alguma fica, por enquanto, | na bôs vontade...". 
Nota da pesquisa:

1. Ms na vertente Mário de Andrade mentor.

Estudo genético:

1. Chrôniqueta apresenta-se em duas versões. A acima registrada foi considerada pela pesquisa versão $\mathrm{B}$, e mostra 1 etapa na escritura: autógrafo a tinta preta (V. análise documentária da versão A: MA-MOE, 150).

2. Elegia, Théoria, Sentimental, Jazz-band apresentam-se em uma única versão A, que mostra 2 etapas na escritura: a-a ${ }_{1}$ :

a: datiloscrito completo;

$\mathrm{a}_{1}$ : rasuras a tinta preta.

MA - MOE, 164

FUSCO, Rosário (1910-1977)

164. Maria Bonita; poesia (MAm)

[Cataguases], s/ data

Autógrafo a tinta azul; papel branco, carimbo azul: "Rosario Fusco."; 1 folha; 29,4/29,6 x 21,9/22,0 cm; vincos; sinais de fungo; rasgamentos nas bordas superior, direita e esquerda; escrita no anverso; assinatura a tinta azul: "Rosario Fusco."; fólio numerado pela pesquisa: (1).

Notas da pesquisa:

1. Ms na vertente Mário de Andrade mentor.

2. V. MA-MOE, 146, nota 2, sobre os ms que RF costumava enviar a MA.

Estudo genético:

1. O ms apresenta-se em uma única versão, A, que mostra 1 etapa na escritura.

MA - MOE, 165

GUARNIERI, Rossini Camargo (1914-1989)

165. Quaresma; poesia (MAm)

São Paulo, 21 mar. 1937

Datiloscrito, cópia carbono roxo; papel branco, filigrana; 2 folhas; 31,7/31,8 x 21,8 cm; vincos; sinais de fungo; escrita no anverso; f. 1: dedicatória: "Pro Mestre Mario"; f. 2: local e data: "S. Paulo, | 21-março-37" e assinatura a tinta preta: "Rossine Camargo Guarnieri”; rasuras a máquina; fólios numerados pela pesquisa: (1)-(2).

Nota da pesquisa:

1. Ms na vertente Mário de Andrade mentor. 
Estudo genético:

1. No arquivo MA o poema se apresenta-se em uma única versão, $\mathrm{A}$, o datiloscrito em cópia carbono que mostra 2 etapas na escritura: a-a $a_{1}$ :

a: datiloscrito completo;

$\mathrm{a}_{1}$ : rasuras a máquina.

MA - MOE, 166

GUARNIERI, Rossini Camargo (1914-1989)

166. Canto de esperança em louvor de Stalingrado; poesia (MAm)

[São Paulo], 18, fev. 1944

Datiloscrito original fita preta, papel branco, filigrana: "ROYAL TYPSI"; 11 folhas; 32,6 x 22,1 cm; f. 6: rasgamento na borda direita; sinais de fungo; furos de grampeamento na margem direita; manchas da fita da máquina; escrita no anverso; $\mathrm{f}$. 2: folha de rosto com autoria, título e data: "Rossini Camargo Guarnieri | CANTO | DE | ESPERANÇA | EM | LOUVOR | DE | STALINGRADO | poema | 1944"; f. 4: 2 dedicatórias: 1. a máquina: "Este poema é dedicado a todos | aqueles que pereceram lutando | pelo advento da Liberdade e da | Justiça em todas as terras do | mundo.", 2. autógrafo a tinta preta: "A Mario de Andrade - | meu exemplo - com todo | o coração do | Rossine Camargo Guarnieri | 18 - 2 - 44"; f. 1, 11 em branco servindo de capa e quarta-capa do ms; folhas numeradas a lápis preto: 1-8; fólios numerados pela pesquisa: $1-11$.

Notas da pesquisa:

1. Ms na vertente Mário de Andrade mentor.

2. Canto de esperança em louvor de Stalingrado foi publicado em 3 poemas de Rossine Camargo Guarnieri (Rio de Janeiro, Edição do Partido Comunista Brasileiro, 1946).

3. RCG enviou o ms a MA junto da carta de 18 fevereiro de 1944, na qual está "Meu querido Mário: | Eu gostaria muito que | você desse a sua opimião de cri- | tico sobre o meu 'Canto de Esperança | em louvor de Stalingrado"”.

Estudo genético:

1. No arquivo MA o texto se apresenta em uma única versão, A, passada a limpo no datiloscrito original que mostra 1 etapa na escritura.

2. Versão A confrontada com a versão B em 3 poemas de Rossine Camargo Guarnieri (ed. cit.) mostra. 
MA - MOE, 167-168

GUIMARAENS, Alphonsus de (Afonso Henrique da Costa Guimaraens 1870-1921)

167. Factum; poesia (MAc)

[Mariana], 22 [jun.] 1919

Autógrafo a tinta preta; papel branco, pautado no anverso; 1 folha; 26,0 x 20,8 cm; irregularidades na borda superior; rasgamento nas bordas direita e esquerda; vincos; sinais de fungo; escrita no anverso; assinatura e data: "Alphonsus de Guimaraens |22IV-919"; rasura a tinta preta; fólio numerado pela pesquisa: (1).

168. Soneto; poesia (MAc)

[Mariana], 22 [jun.] 1919

Apógrafo MA a tinta azul; papel branco, pautado no anverso; 1 folha; 25,8/25,9 x $20,8 \mathrm{~cm}$; irregularidades na borda superior; pequenos rasgamentos nas bordas esquerda e direita; vincos; sinais de fungo; escrita no anverso; assinatura: autógrafo: "Alphonsus de Guimaraens"; fólio numerado pela pesquisa: (1).

Ms acondicionados em papel almaço branco, s/ pauta; 2 folhas; 33,0 x 21,8 cm; sinais de fungo; f. 1: vinco no canto superior direito; f. 2: marcas de ferrugem e vinco transversal; fólios numerados pela pesquisa: (1)-(2).

$\underline{\text { Nota MA em autógrafo a tinta preta na f. 1: "2 autógrafos | de | Alphonsus de }}$ Guimaraens".

Anexo:

Pauvre lyre; poesia

S/. local, s/. data

Apógrafo MA a tinta azul; papel branco, pautado no anverso; 2 folhas; 25,8/25,9 x $20,9 \mathrm{~cm}$; irregularidades na borda superior; f. 1: rasgamento na borda esquerda; vincos; sinais de fungo; escrita no anverso; indicação de autoria no final do poema: “Alphonsus Guimarães"; fólios numerados pela pesquisa: (3)-(4).

O ms recolhe os sonetos: "Tes lévres sont deux fleurs sublimes et royales," e "Vers le ciel, vers l'azur ma douce âme s'élance".

Notas da pesquisa:

1. Ms na vertente Mário de Andrade colecionador.

2. Data atestada pela pesquisa que corrigiu inversão feita por Alphonsus de Guimaraens quando, ao assinar Factum, grafou "22-IV-919" ao invés de "22-VI-919", pois MA fez sua primeira viagem a Minas Gerais em junho de 1919, durante as férias que usufruia como professor no Conservatório Dramático e Musical de São Paulo. O viajante o comprova em "Alphonsus", crônica publicada na revista paulistana A Cigarra (a. 4, no 117) em $1^{\circ}$ de agosto, 1919 , na qual focaliza seu encontro com o poeta de Dona mística, em Mariana, mas sem referência aos ms. A materialidade dos documentos indica que, em 1919, MA recebeu o autógrafo de Factum e uma cópia do Soneto, por assinada pelo consagrado simbolista. Na mesma ocasião, o visitante teria copiado os dois sonetos de Pauvre lyre. A dádiva se vê confirmada em 10 de março de 1941, na carta a Alphonsus de Guimaraens Filho, na qual Mário comete um lapso envolvendo a mesma viagem a 
Minas: "Há surpresas gostosas como essa, de hoje, de achar dois sonetos de seu Pai, um, o 'Factum' da inteira mão dele e outro, cópia minha, feita na presença dele e que ele autografou. Em ambos os sonetos há pequenas variantes das Obras Completas. [...] Uma coisa me deixou completamente atarantado e vai ser um problema literário de minha vida. Minha primeira viagem a Minas foi em 17 e então fui visitar seu Pai em Mariana. [...] Estive com seu Pai ali pela manhã, mais de uma hora, [...] Pedi pra copiar o 'Vaga em redor de ti...' que ele em seguida se prontificou a autografar. [...] Ora, como me veio parar às mãos esse autógrafo datado de 1919! A tinta é diferente da de 1917 e prova não haver engano de data, embora o papel seja o mesmo. Seria acaso o João Alphonsus que me deu esse autógrafo? É autógrafo porque a assinatura é a mesma do soneto que copiei e mesmo estilo de letra. Pergunte ao João Alphonsus" (ANDRADE, Mário e BANDEIRA, Manuel. Itinerários - Cartas a Alphonsus de Guimaraens Filho. Ed. anotada de Alphonsus de Guimaraens Filho. São Paulo, Duas Cidades, 1974, p. $25-$ 26; no livro está a transcrição da crônica de 1919). A leitura do ms revela que Soneto tem, como primeiro verso, "Vaga em redor de ti...". Trata-se, portanto de traição da memória decorridos 32 anos, omitindo, inclusive a cópia dos sonetos de Pauvre lyre.

3. Em carta de Mariana, em 24 de agosto de 1919, Alphonsus de Guimaraens agradece MA: "Acabo de | ler em um quotidiano de Juiz de Fó- $\mid$ ra, o bello artigo que escreveu sobre | mim e sobre os fugaces instantes de jubilo que | sua visita me proporcionou. | Como v. me prometteu escre- | vel-o pra Cigarra, penso ter sido trans- $\mid$ cripto. Se assim fôr, espero o $\mathrm{n}^{\mathrm{o}}$ da for- $\mid$ mosa revista."

4. O papel e a tinta idênticos, bem como a crônica em A Cigarra, explicam a presença da cópia dos sonetos não mencionada por MA na carta ao filho do poeta. Em "Alphonsus" está: "Deu-me mais versos para ler. Tive nas mãos os alexandrinos da 'Pauvre Lyre', escritos em francês, e onde, numa atmosfera de milagre, revive a doçura de Verlaine, Lamartine e de Musset...".

5. Na biblioteca MA acha-se um exemplar de Pauvre lyre (Ouro Preto, Editora Mineira Paulo Brandão \& Comp, 1921).

Estudo genético:

1. No arquivo MA Factum se apresenta em uma única versão, A, o autógrafo, A, que mostra 2 etapas na escritura: $a-a_{1}$ :

a: autógrafo completo;

$\mathrm{a}_{1}$ : rasura a tinta preta.

2. O estudo netético não se ocupou dos apógrafos.

MA - MOE, 169

GUIMARAENS, Liliana B. V. de

169. Boneca; Cigana; A cigana; Primavera; poesia (MAm)

[Belo Horizonte, ant. maio 1944]

Datiloscrito cópia carbono preto; papel branco; 1 folha; 32,5 x 22,2/22,3 cm; vincos; sinais de fungo; manchas de carbono; escrita no anverso; autoria na margem superior: "Versos de Liliana B. V. Guimaraens"; fólio numerado pela pesquisa: (1). Nota João Alphonsus a tinta preta: "Para o Mario". 
Nota MA a lápis vermelho na margem direita: "O João Alphonsus me pediu escrever | à Liliana".

Notas da pesquisa:

1. Ms na vertente Mário de Andrade mentor.

2. A escritora é a filha do escritor João Alphonsus e de Esmeralda Viana de Guimaraens.

3. Data atestada com base na época da morte de João Alphonsus.

Estudo genético:

1. No arquivo MA o texto se apresenta em uma única versão, A, o datiloscrito que mostra 1 etapa na escritura.

MA - MOE, 170

GUIMARAENS FILHO, Alphonsus de (Alphonsus Henriques de Guimaraens Filho 1918-)

170. Comunhão; Ingênua; Harmonia; Tarde; Poema íntimo; Momento; Pudesse eu me esquecer...; poesia (MAm)

[Belo Horizonte,] jun. 1939, mar. 1940, [ant. 19 ago. 1940]

Datiloscrito original fita preta; papel branco; 3 folhas; 29,2 x 20,0/20,1 cm, com variações em mm; vincos; sinais de fungo; escrita no anverso; f. 3: assinatura a tinta preta no verso: "Alphonsus de Guimaraens Filho"; folhas numeradas pelo escritor: 23; rasuras a máquina e a tinta preta; fólios numerados pela pesquisa: (1)-(3). Notas MA.

\section{Harmonia:}

Notas MA a lápis vermelho: v. 7: grifo na palavra "transcendental" e exclamação na margem direita.

Tarde:

Notas MA: f. 2: a lápis vermelho: v. 11: grifo na palavra "gera"; a lápis preto na margem direita: comentário a respeito da palavra grifada.

Poema íntimo:

Data no final do poema: "(junho de 1939)".

Momento:

Data: "(Março, 40)".

Nota MA a lápis preto na margem direita: comentário ao poema: "ótimo".

Pudesse eu me esquecer...:

Nota MA a lápis vermelho na margem inferior do anverso: "(vire)". 
Notas da pesquisa:

1. Ms na vertente Mário de Andrade mentor.

2. As datas presentes nos poemas dizem respeito à criação; a carta de AGF a MA, de Belo Horizonte, 19 de agosto de 1940, acompanhou os $7 \mathrm{~ms}$ e serviu para datar os documentos que não possuem essa referência explícita; forneceu-lhes também o local da escrita: "De acôrdo com o pedido que você me fez | na sua carta, mando-lhe alguns poemas no- $\mid$ vos. Pode dizer sincerissimamente o que pensa | deles. Aliás, estou achando muito inútil esta | advertência, pois conheço bem a sua sinceri- | dade e a admiro". (Ref.: série Correspondência Mário de Andrade - sub-série Correspondência passiva; MA-C-CPL, $\mathrm{n}^{\mathrm{o}}$ 3584).

3. Poema íntimo foi publicado em "Nostalgia dos Anjos" (Poemas reunidos, Rio de Janeiro, José Olympio Editora, 1960)

4. Em 30 de setembro de 1940, MA endereçou carta a AGF comentando os poemas recebidos (ANDRADE, Mário e BANDEIRA, Manuel. Itinerários - Cartas a Alphonsus de Guimaraens Filho. Ed. anotada de Alphonsus de Guimaraens Filho. Ed. cit. p. 18-22). A resposta veio de Belo Horizonte em 5 de outubro de 1940, acompanhada de novos poemas (Ref.: série Correspondência Mário de Andrade - subsérie Correspondência passiva; MA-C-CPL, $\mathrm{n}^{\circ} 3585$ )

5. Os poemas nos ms não fazem parte de Lume de estrelas, livro de estréia do poeta mineiro (Belo Horizonte, Edições Mensagem, 1940). O exemplar na biblioteca de MA traz anotações marginais do crítico vinculadas ao artigo "Lume de estrelas", publicado em 23 de junho de 1940, na coluna Vida literária, por ele mantida no Diário de Notícias do Rio de Janeiro (republicado em ANDRADE, Mário. Vida literária. Ed. anotada de Sonia Sachs. São Paulo, Hucitec, 1993, p. 215-219). Em sua primeira missiva a MA, de Belo Horizonte, 3 de julho de 1940, AGF agradece e comenta o artigo (Ref.: série Correspondência Mário de Andrade - sub-série Correspondência passiva; MA-C-CPL, $\left.\mathrm{n}^{\mathrm{o}} 3583\right)$.

Estudo genético:

1. No arquivo MA o texto se apresenta em uma única versão, passada limpo, A, o datiloscrito que mostra em Harmonia e Momento 1 etapa na escritura e, em Comunhão, Ingênua, Tarde, Poema íntimo, Pudesse eu me esquecer... 3 etapas na escritura: a- $\mathrm{a}_{1}-\mathrm{a}_{2}$ : a: datiloscrito completo;

$\mathrm{a}_{1}$ : rasuras a máquina; $\mathrm{a}_{2}$ : rasuras a tinta preta.

2. Versão A confrontada com versão B, em Poemas reunidos (ed. cit.) exibe poucas variantes.

MA - MOE, 171

GUIMARAENS FILHO, Alphonsus de (Alphonsus Henriques de Guimaraens Filho 1918-)

171. Mãos; Vestido branco; Pesadelo; Saudade; Os desconhecidos; Delírio; O amor simples e sem segredos; Teu sorriso; Pressentimento; poesia (MAm)

[Belo Horizonte, ant. 5 out. 1940] 
Datiloscrito original fita preta; papel branco; 5 folhas; $28,7 / 29,0 \times 20,1 \mathrm{~cm}$, com variações em $\mathrm{mm}$; f. 1: pequeno rasgamento na borda direita; f. 2-3: pequeno rasgamento na borda inferior; vincos; sinais de fungo; escrita no anverso; rasuras a máquina e a tinta preta; fólio numerado pela pesquisa: (1). Nota AGF em datiloscrito: f. 5 na margem inferior: "(Todos os poemas são recentes. Da re- | messa passada, apenas o POEMA INTIMO |é de março de 39)". Notas MA.

Nota MA a lápis azul: numeração das folhas na margem superior à direita: 1-5.

\section{Delírio:}

Nota MA a lápis vermelho na margem direita: 2 traços verticais destacando o poema e comentário: " 1 a ordem".

Notas da pesquisa:

1. Ms na vertente Mário de Andrade mentor.

2. Data e local atestados com base na carta de MA a AGF, do Rio de Janeiro em 4 de janeiro de 1941, onde comenta os poemas recebidos no ms. (ANDRADE, Mário e BANDEIRA, Manuel. Itinerários - Cartas a Alphonsus de Guimaraens Filho. Ed. anotada de Alphonsus de Guimaraens Filho. Ed. cit., p. 22-24).

3. Delírio foi publicado, com dedicatória a MA, em Poemas reunidos (ed. cit.).

4. Na carta de Belo Horizonte, 26 de janeiro de 1941, AGF agradece a leitura e os comentários de MA: "Sua carta me trouxe a maior alegria. Tanto a $\mid$ esperei, $\mid[\ldots]$. Muito obrigado, Mário, por suas impressões sôbre | os meus novos poemas. E principalmente pela | dúvida que lançou no meu espírito quanto | ao soneto irregular...". Essa discussão, sobre o soneto irregular, prossegue ao longo da correspondência trocada entre ambos.

\section{Estudo genético:}

1. No arquivo MA o texto dos poemas Mãos, Vestido branco, Pesadelo, Saudade, Os desconhecidos, $O$ amor simples e sem segredos, Teu sorriso, Pressentimento apresentase em uma única versão, passada limpo.

2. AGF encaminhou a MA duas versões do texto de Delírio. A versão chegou primeiro ao arquivo MA foi, por essa razão, considerada versão A, passada limpo, o datiloscrito original que mostra 1 etapa na escritura. V. a análise documentária da versão B: MAMOE, 172. A versão A foi confrontada com a versão B e com a versão C, impressa em Poemas reunidos (ed. cit.). Há poucas variantes.

3. Vestido branco mostra 1 etapa na escritura.

4. Pesadelo, Saudade, Os desconhecidos, Delírio, e Pressentimento trazem 2 etapas na escritura: a-a $a_{1}$ : a: datiloscrito completo; $\mathrm{a}_{1}$ : rasuras a máquina.

5. Teu sorriso mostra 2 etapas na escritura: $\mathrm{a}_{-} \mathrm{a}_{1}$ : a: datiloscrito completo; $\mathrm{a}_{1}$ : rasura a tinta preta.

6. Mãos e $O$ amor simples e sem segredos mostram 3 etapas na escritura: $\mathrm{a}_{-} \mathrm{a}_{1}-\mathrm{a}_{2}$ : a: datiloscrito completo; $\mathrm{a}_{1}$ : rasuras a máquina; $\mathrm{a}_{2}$ : rasuras a tinta preta. 
MA - MOE, 172

GUIMARAENS FILHO, Alphonsus de (Alphonsus Henriques de Guimaraens Filho 1918-)

172. Delíro; poesia (MAm)

[Belo Horizonte], 24 out. 1940

Autógrafo a tinta preta; papel branco, folha de caderno de contabilidade pautada no anverso; 1 folha; 9,6 x 10,0 cm; bordas esquerda e superior recortadas; sinais de fungo; escrita no anverso; assinatura: "Anphonsus Filho"; data: "outubro- 24 1940"; rasuras a tinta preta; fólio numerado pela pesquisa: (1).

Notas da pesquisa:

1. Ms na vertente Mário de Andrade mentor.

2. Delírio foi publicado,

Estudo genético:

1. AGF encaminhou a MA duas versões do poema Delírio. A acima registrada, autógrafo passado a limpo foi a segunda e por isso considerada versão B. V. a análise documentária da versão A: MA-MOE, 171.

2. Delírio mostra 2 etapas na escritura: $\mathrm{b}-\mathrm{b}_{1}$ :

b: autógrafo completo;

$\mathrm{b}_{1}$ : rasuras a tinta preta.

3. A versão $B$ foi confrontada com a versão $A$ no ms e com a versão $C$ impressa em Poemas reunidos (ed. cit.). Há poucas variantes.

MA - MOE, 173

GUIMARAENS FILHO, Alphonsus de (Alphonsus Henriques de Guimaraens Filho 1918-)

173. Foste a primeira; Céu de junho; $O$ aflito olhar; Sorriso; "Não quero que a loucura me transporte"; poesia (MAm)

[Belo Horizonte], jan. 1942

Autógrafo a tinta preta; papel branco, pautado no anverso; 3 folhas; f. 1-2: 25,3 x 18,3 cm, f. 3: 25,0/25,2 x 18,0/18,3 cm; vincos; sinais de fungo; f. 3: marcas de ferrugem no verso; f. 1, 3: escrita no anverso, f. 2 escrita no anverso e no verso; f. 2 : assinatura na margem inferior, no verso: "Alphonsus de Guimaraens Filho"; f. 3: assinatura e data: "Alphonsus de Guimaraens Filho | janeiro - 1942"; folhas numeradas pelo escritor: II-III; rasuras a tinta preta; fólios numerados pela pesquisa: (1)-(3). Nota $\underline{\text { AGF. }}$

"Não quero que a loucura me transporte":

Nota AGF a tinta preta: f. 3 na margem superior: "Vai aqui um soneto, dos mais novos...".

Nota da pesquisa:

1. Ms na vertente Mário de Andrade mentor. 
Estudo genético:

1. No arquivo MA os textos apresentam-se em uma única versão, passada limpo, A, o autógrafo que mostra 1 etapa na escritura em Foste a primeira, Céu de junho, $O$ aflito olhar e Sorriso; em "Não quero que a loucura me transporte" 2 etapas na escritura: a-a $a_{1}$ : a: autógrafo completo;

$\mathrm{a}_{1}$ : rasuras a tinta preta.

\section{MA - MOE, 174}

GUIMARAENS FILHO, Alphonsus de (Alphonsus Henriques de Guimaraens Filho 1918-)

174. A cidade branca; poesia (MAm)

Belo Horizonte, set. 1942

Datiloscrito, cópia carbono roxo; papel branco; 1 folha; 32,6 x 21,9 cm; rasgamento na borda superior; escrita no anverso; assinatura a tinta preta: "Alphonsus de Guimaraens Filho"; data: "Belo Horizonte, setembro de 1942"; rasuras a máquina; fólio numerado pela pesquisa: (1).

Notas da pesquisa:

1. Ms na vertente Mário de Andrade mentor.

2. O poema permaneceu inédito. Os poemas permaneceram inéditos.

Estudo genético:

1. No arquivo MA o texto apresenta-se em uma única versão, A, a cópia em datiloscrito que mostra 2 etapas na escritura: a- $a_{1}$ :

a: datiloscrito completo;

$\mathrm{a}_{1}$ : rasuras a máquina.

MA - MOE, 175

GUIMARAENS FILHO, Alphonsus de (Alphonsus Henriques de Guimaraens Filho 1918-)

175. Carta a Stalingrado; poesia (MAm)

[Belo Horizonte], 12 out. 1942

Datiloscrito, cópia carbono preto; papel branco, filigrana: "GLORIA"; 2 folhas; 33,1 x 22,0/22,1 cm; f. 1: rasgamento nas bordas direita e esquerda, f. 2: rasgamento nas bordas direita e superior; cantos amassados; vincos; sinais de fungo; furo de grampeador na margem superior à esquerda; escrita no anverso; f. 2: data: "12.X.42"; rasuras a máquina; fólios numerados pela pesquisa: (1)-(2).

Nota da pesquisa:

1. Ms na vertente Mário de Andrade mentor. 
Estudo genético:

1. No arquivo MA o texto apresenta-se em uma única versão, A, a cópia em datiloscrito que mostra 2 etapas na escritura: a- $a_{1}$ :

a: datiloscrito completo;

$\mathrm{a}_{1}$ : rasuras a máquina.

\section{MA - MOE 176}

GUIMARAENS FILHO, Alphonsus de (Alphonsus Henriques de Guimaraens Filho 1918-)

176. Momento; Confidência; Não me afagues sequer; Ternura; Coisas da infância; Que importa amar; Trago-te a paz de um céu; Melodia; poesia (MAm)

[Belo Horizonte, 1942, mar.- abr. 1943, post. dez. 1943]

Autógrafo a tinta azul; papel jornal; 4 folhas; 32,1/32,2 x 21,6/21,9 cm, com variação em mm na largura; borda esquerda recortada; vincos; sinais de fungo; escrita no anverso; f. 4 assinatura: "Alphonsus de Guimaraens Filho"; folhas numeradas pelo escritor: 2-4; rasuras a tinta azul; fólios numerados pela pesquisa: (1)-(4). Nota AGF a tinta azul: f. 1 na margem superior: "Do Nostalgia dos Anjos".

Momento:

Data no final do poema: “(1943)”.

Confidência:

Data no final do poema: "(abril de 1943)".

Não me afagues sequer:

Data no final do poema: "(março de 1943)".

Ternura:

Data no final do poema: “(dezembro de 1943)".

Nota AGF acima do título: "Dos 'Sonetos da Ausência'".

Coisas da infância:

Data no final do poema: “(1943)”.

Que importa amar:

Data no final do poema: “(1942)".

Trago-te a paz de um céu:

Data no final do poema: “(1943)".

Melodia:

Data no final do poema: “(1943)”. 
Notas da pesquisa:

1. Ms na vertente Mário de Andrade mentor.

2. Os "Sonetos da Ausência" sairão em 1960 em Poemas reunidos (Rio de Janeiro, José Olympio Editora).

\section{Estudo genético:}

1. No arquivo MA os textos apresentam-se em uma única versão, A, passada a limpo, o autógrafo que mostra em Não me afagues sequer, Ternura, Que importa amar, Trago-te a paz de um céu e Melodia 1 etapa na escritura, e em Momento, Confidência e Coisas da infância 2 etapas na escritura: a- $\mathrm{a}_{1}$ :

a: autógrafo completo;

$\mathrm{a}_{1}$ : rasuras a tinta.

MA - MOE, 177

GUIMARAENS FILHO, Alphonsus de (Alphonsus Henriques de Guimaraens Filho 1918-)

177. Amada minha; Embalo; Um silêncio molhado; "Suspiros de amor, talvez, ou de odios guerreiros"; Embalo do luar de junho; Canção da moça do lenço azul; Rosa da montanha; "Hoje estou que nem sei... Com umdesejo violento"; Canção; poesia

[Belo Horizonte,] fev., jul., set.- nov. 1943.

Datiloscrito original, fita preta e vermelha; papel jornal; 9 folhas; f. 1-7: 32,2 x 21,6 $\mathrm{cm}$, com variações em mm, f. 8-9: 22,6 x 21,6/21,7 cm; f. 1-7: borda esquerda cortada; f. 8-9: bordas esquerda e inferior cortadas; vincos; sinais de fungo, escrita no anverso; f. 6-7 numeradas pelo escritor: II-III; rasuras a máquina e a tinta azul; fólios numerados pela pesquisa: (1)-(9). Notas MA.

Conjunto de ms acondicionado em pasta improvisada em papel branco dobrado ao meio; 32,3 x 21,9 cm; rasgamento na borda inferior; sinais de fungo; fólio numerado pela pesquisa: (1).

Nota MA a lápis vermelho: "Alphonsus de Guimaraens | Filho | (Originais)”.

Amada minha:

Data: "(Julho de 1943)".

Nota MA a lápis vermelho no verso da folha: "Alphonsus", "Alphonsus | Versos | Carta".

Embalo:

Data: "(fevereiro de 1943)".

Um silêncio molhado:

Data: "(setembro de 1943)".

"Suspiros de amor, talvez, ou de odios guerreiros":

Notas MA a lápis preto: sugestões de substituição. 
Embalo do luar de junho:

Data: "(Outubro de 1943)".

Notas MA a lápis preto: sugestão de substituição e comentários.

Canção da moça do lenço azul:

Data: “(8.X.1943)".

Nota MA a lápis preto: comentário: "lindo".

Rosa da montanha:

Data: "-6 de novembro de 1943-".

Notas MA: a lápis preto: sugestões e comentários; a lápis vermelho no verso da folha:

"Alphonsus".

"Hoje estou que nem sei... Com umdesejo violento":

Data: "( $1^{\circ}$ de outubro de 1943)".

Nota MA a lápis preto: comentário.

Nota da pesquisa:

1. Ms na vertente Mário de Andrade mentor.

Estudo genético:

1. No arquivo MA os textos apresentam-se em uma única versão, A, passada a limpo, o datiloscrito original que mostra, em Canção da moça do lenço azul, 1 etapa na escritura e em Amada minha, Um silêncio molhado e Canção, 2 etapas na escritura: a-a $a_{1}$ :

a: datiloscrito completo;

$\mathrm{a}_{1}$ : rasuras a máquina;

2. Embalo e Embalo do luar de junho mostra 2 etapas na escritura: a-a

a: datiloscrito completo;

$\mathrm{a}_{1}$ : rasuras a tinta azul;

3. "Suspiros de amor, talvez, ou de odios guerreiros", Rosa da montanha e "Hoje estou que nem sei... Com umdesejo violento" mostra 3 etapas na escritura: a-a $a_{1}-a_{2}$ :

a: datiloscrito completo;

$\mathrm{a}_{1}$ : rasuras a máquina;

$\mathrm{a}_{2}$ : rasuras a tinta azul.

MA - MOE, 178

GUIMARAENS FILHO, Alphonsus de (Alphonsus Henriques de Guimaraens Filho 1918-)

178. Elegia desesperada; poesia (MAm)

[Belo Horizonte], 28 jan. 1944

Autógrafo a tinta azul; papel jornal; 1 folha; 32,0 x 20,6/21,6; borda esquerda cortada; vincos; sinais de fungo; escrita no anverso; assinatura e data: "AGFilho | 28I-44"; fólio numerado pela pesquisa: (1). 
Nota da pesquisa:

1. Ms na vertente Mário de Andrade mentor.

Estudo genético:

1. No arquivo MA o texto se apresenta-se em uma única versão, A, passada a limpo, o autógrafo que mostra 1 etapa na escritura.

MA - MOE, 179

GUIMARAENS FILHO, Alphonsus de (Alphonsus Henriques de Guimaraens Filho 1918-)

179. "Com a rispidez de um vento enlouquecido"; "Em cada casa, em cada luz, em cada rua"; poesia (MAm)

[Belo Horizonte], 12 mar. 1944

Autógrafo a tinta preta; papel branco; 2 folhas; $32,5 \times 22,1 \mathrm{~cm}$; vinco; sinais de fungo; escrita no anverso; folha numerada pelo escritor: II; f. 1: assinatura e data: "Alphonsus Filho | Março - 12 - 1944"; f. 2: tinta da escrita borrada na última estrofe, data e assinatura: "12.3.44 Alphonsus Filho"; rasura a tinta preta; fólios numerados pela pesquisa: (1)-(2).

Nota da pesquisa:

1. Ms na vertente Mário de Andrade mentor.

Estudo genético:

1. No arquivbo MA o texto apresenta-se em uma única versão, A, passada a limpo, o autógrafo que mostra em "Com a rispidez de um vento enlouquecido" 1 etapa na escritura, e em "Em cada casa, em cada luz, em cada rua" 2 etapas na escritura: a-a ${ }_{1}$ :

a: autógrafo completo;

$\mathrm{a}_{1}$ : rasura a tinta.

MA - MOE, 180

GUIMARAENS FILHO, Alphonsus de (Alphonsus Henriques de Guimaraens Filho 1918-)

180. Caminho escuro; poesia (MAm)

[Belo Horizonte], 29 mar. 1944

Autógrafo a tinta preta; papel branco, timbrado: "SERVIÇO PÚBLICO DO ESTADO

DE MINAS GERAIS"; 1 folha; 31,8 x 21,7/21,8 cm; vincos; sinais de fungo; 2 furos para arquivamento na margem esquerda; manchas de tinta azul; escrita no anverso; data e assinatura: "29.3.44 AGFilho"; rasuras a tinta preta e a tinta azul; fólio numerado pela pesquisa: (1).

Nota da pesquisa:

1. Ms na vertente Mário de Andrade mentor. 
Estudo genético:

1. No arquivo MA o ms apresenta-se em uma única versão, $\mathrm{A}$, passada alimpo que mostra 3 etapas na escritura: $a-a_{1}$ :

a: autógrafo a tinta preta;

$\mathrm{a}_{1}$ : rasuras a tinta preta;

$\mathrm{a}_{2}$ : rasuras a tinta azul.

MA - MOE, 181

GUIMARAENS FILHO, Alphonsus de (Alphonsus Henriques de Guimaraens Filho 1918-)

181. Poema das 23 horas; poesia (MAm)

[Belo Horizonte] 10 maio 1944

Autógrafo a tinta azul; papel branco; 2 folhas; f. 1: 22,2 x 17/17,2 cm, f. 2: 22,2 x 15,2/15,5 cm; borda esquerda recortada; vincos; sinais de fungo; escrita no anverso e no verso; páginas numeradas pelo escritor: $2-4$; f. 2 : assinatura e data no verso: "Alphonsus | Filho | 10.V.44"; rasuras a tinta azul; fólios numerados pela pesquisa: (1)-(2).

Nota da pesquisa:

1. Ms na vertente Mário de Andrade mentor.

Estudo genético:

1. No arquivo MA o texto apresenta-se em uma única versão, A, passada a limpo, o autógrafo que mostra 2 etapas na escritura: $a-a_{1}$ :

a: autógrafo completo;

$\mathrm{a}_{1}$ : rasuras a tinta.

MA - MOE, 182

GUIMARÃES, Rute (Rute Botelho Guimarães 1920-?)

182. O inferno e seus caminhos; ensaio/ folclore (MAm)

[São Paulo, ant. 02 jun. 1944]

Datiloscrito original, fita azul; papel branco, f. 1-16, 25-28, 30, 32-33: filigrana; 33 folhas; 33,0 × 22,0 cm, com variações em mm; f. 1: rasgamento na borda inferior; vinco na parte superior da folha; sinais de fungo; f. 11, 28, 33: ferrugem de clipe; $f$. 14: manchas de tinta preta no verso; f. 17: dois pequenos furos na margem esquerda; f. 30: marcas de ferrugem; escrita no anverso; folhas numeradas a lápis preto: 1-33; rasuras a máquina e a tinta preta; fólios numerados pela pesquisa: (1)-(3) (3). Nota RG a lápis preto na margem superior da f.1: "Nota: pode rabiscar".

Notas MA:

1) a lápis preto: f. 1-3, 27, 29: comentários, sugestões de substitição, observações, f. 8: sinal de cruza na margem esquerda, f. 10: colchete destacando trecho e interrogação na margem esquerda. 
2) a lápis preto em, folha de bloco branca, borda superior picotada; 10,6 x 6,9 cm; sinais de fungo; ferrugem de clipe; escrita no anverso: "Ruth Guimarães | Talvez interesse ler | a peça de Antonio | José da Silva, | o Judeu, "Obras do | Diabinho da Mão | Furada" | Operas 1 ${ }^{\circ}$ vol - L.477 | edições cultura | 72939".

3) a tinta preta; 1 folha de papel branco; 22,0 x 16,4 cm; sinais de fungo; escrita no anverso: comentários e observações sobre o texto no ms.

\section{Notas da pesquisa:}

1. Ms na vertente Mário de Andrade mentor.

2. Local e data atestados com base na correspondência trocada entre RG e MA. Em 18 de abril de 1944, RG pede orientação de MA para trabalho que está realizando sobre o diabo no folclore do Brasil. Em 2 de junho de 1944 envia-lhe um capítulo do estudo O diabo no folclore brasileiro: "Naturalmente sei que é audácia em demasia, di- | rigir-lhe esta. No entanto, V. S. é como um velho amigo, | com quem me habituei a conversar atravez dos seus livros, [...] Estou escrevendo um trabalho sobre - 'O diabo no | folclore brasileiro'. [...] Vou fazer o pedido depressa, an- | tes que perca a coragem: podia, por favor, ajudar-me a en- | tender 'o diabo brasileiro? [...] Queria uma indicação, qualquer cousa que | me permitisse remontar às origens”. (Ref.: série Correspondência Mário de Andrade - sub-série Correspondência passiva; MA-C-CPl, nº 3605)

\section{Estudo genético:}

1. No arquivo MA o texto apresenta-se em uma única versão, A, passada a limpo, o datiloscrito original que mostra 3 etapas na escritura: $a-a_{1}-a_{2}$ :

a: datiloscrito completo;

$\mathrm{a}_{1}$ : rasuras a máquina;

$\mathrm{a}_{2}$ : rasuras tinta preta.

2. A versão A confrontada com a versão B em GUIMARÃES, Rute. "O inferno e seus caminhos", in: Os filhos do mêdo. Porto Alegre, Editora Globo, 1950, p. 3-45, mostra variantes.

\section{MA - MOE, 183}

IVO, Ledo (1924-)

183. O clube; poesia (MAm)

[Maceio/ Rio de Janeiro, ant. 1944]

Datiloscrito, cópia carbono azul; papel branco; 43 folhas; 21,9 x 16,6/16,9 cm, com variações em mm; f. 1: irregularidades nas bordas esquerda e inferior e rasgamento na borda direita; f. 2-18, 29: borda esquerda recortada; f. 19-21: borda esquerda rasgada; f. 22, 26-27, 31, 35-36, 41: bordas direita e inferior cortadas; f. 23: borda esquerda cortada; f. 24-25, 28, 30, 32-34, 37-38, 39, 42-43: bordas esquerda e inferior cortadas; f. 40: bordas esquerda e superior cortadas; f. 2: rasgamentos: nas bordas superior e inferior e na parte central da folha; f. 3: margem esquerda amassada; f. 4: 2 pequenos rasgamentos na borda inferior; f. 15: canto superior direito amassado; f. 24: rasgamento na borda direita; f. 29: pequenos rasgamentos e amassados na borda inferior à direita; f. 33-34: borda superior amassada; f. 35: canto superior direito 
amassado; f. 37: rasgamento na borda superior à direita, cantos superior e inferior direitos amassados; f. 41-43: canto superior direito amassado; vincos, sinais de fungo; f. 3, 6-15, 17-21: manchas de carbono; f. 4, 42-43: letras manchadas; f. 1, 5, 22-35, 37, 41-43: 1 furo; f. 14: palavras apagadas; escrita no anverso; f. 1: capa com autoria,

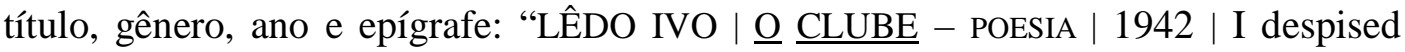
myself and the voices of $\mid$ my accursed human education. | (D. H. Lawrence)"; rasuras a máquina e a tinta preta; fólios numerado pela pesquisa: 1-43. Notas MA.

O conjunto de ms apresenta os seguintes títulos: Hydra femea; Subúrbio; Cantiga para a dama de ópera; Rondó do amor postal; Rondó cativo; Noturno implacavel; A queda de Vega; Aeródromo; Balada matinal; Kaus australis; Elegia; Apelo á ária; A medusa; Canção do mundo sem descoberta; Pablo; Madrigal em perigo; Berceuse do ano terrivel; Carnaval deshonesto; Noturno da pensão esperança; A devoradora; Canção; Sideral; Endereço do sobrado sem música; Dalila; O transporte; A morte; Elza; Balada da constelação; As paraquedistas; Companhia noturna; Ofélia em ré menor; Idílio anormal; A virgem; $O$ regresso; Canção do aluno de violino; Angelina Marques; Beatriz; Morte na areia; A memória; A lua.

Cantiga para a dama de ópera:

Nota MA a lápis preto: traço sobre palavra no v. 11: "as mais insendaveis das mortas:".

Rondó do amor postal:

Nota MA a lápis preto: traço sobre palavra no v. 11: "não $\Theta$ atingirão".

Rondó cativo:

Notas MA a lápis preto: sugestões de substituição.

Noturno implacavel:

Notas MA a lápis preto: sugestões de substituição.

A queda de Vega:

Nota MA a lápis preto: sugestão de substituição.

Balada matinal:

Notas MA a lápis preto: sugestões de substituição.

Canção do mundo sem descoberta:

Dedicatória: "PARA WILLY LEWIN".

Berceuse do ano terrível:

Notas MA: circundando trechos.

Noturno da pensão esperança:

Nota MA a lápis preto: sugestão de substituição. 
A devoradora:

Notas MA: travessões na margem esquerda.

As paraquedistas:

Nota MA a lápis preto: parêntese na margem esquerda destacando os versos 7 e 8 .

Notas da pesquisa:

1. Ms na vertente Mário de Andrade mentor.

2. Local e datas atestados com base no fato de Ledo Ivo ter vivido em Maceió até 1943, quando se transferiu para o Rio de Janeiro, e no PS da carta do poeta a MA, escrita na então capital da República, em 6 de março de 1944, onde se lê: "Por intermedio do Milliet, mandei pra você - depois de ele os ler - uma porrada de poemas antigos".

Estudo genético:

1. No arquivo MA o conjunto de ms apresenta-se em uma única versão, A, cópia em datiloscrito que mostra, em Sideral, $O$ transporte, Elza, Balada da constelação, As paraquedistas, Idílio anormal, Morte na areia, A memória e A lua, 1 etapa na escritura; em Cantiga para a dama de ópera, 2 etapas na escritura: $\mathrm{a}_{-} \mathrm{a}_{1}$ : a: datiloscrito completo; $\mathrm{a}_{1}$ : rasura a tinta preta.

2. Beatriz mostra 3 etapas na escritura: $\mathrm{a}-\mathrm{a}_{1}-\mathrm{a}_{2}$ : a: datiloscrito completo; $\mathrm{a}_{1}$ : rasuras a máquina; $\mathrm{a}_{2}$ : rasuras a tinta preta.

3. Os demais poemas mostram 2 etapas na escritura: $a_{-} a_{1}$ : a: datiloscrito completo; $\mathrm{a}_{1}$ : rasuras a máquina.

MA - MOE, 184

LACERDA, Carlos (Carlos Frederico Werneck Lacerda 1914-1977)

184. Boia; Feriado; Demagogia; Maldição; "Passou batendo"; Berceuse; Instante; Belêsa da onda; Cena ("No girau entre as quatro paredes"); Cena ("Duro e parado como um poste"); "Canta nos teus olhos uma alegria"; Liberdade dos presos proletarios; Supremacia do Espirito; "Apertando junto do seio"; Classico ("Caia a gota reluzente"); Toada do servente de pedreiro; "Camponês"; Elogio do medico morto; Gordo Sinistro; Classico ("Senhora, quem sois"); Vaticinio do Vaticano; Imprensa livre...; Jericó; Jardim fechado; "Punhos fechados"; Gramatica; Paisagem noturna; "Os olhos do avião"; Trova; Imagem; Vago; Instantaneo; Paisagem triste; Pacifismo; Memorandum; Pensamentos escolhidos; Vôo; Amor; Boletim internacional; Fenomenos; "O pernilongo"; poesia (MAm)

[Vassouras, ant. 2 fev. 1934]

Datiloscrito, cópia carbono azul; papel de seda branco; 10 folhas; 32,4/32,7 x 22,0/22,1 cm, com variações em mm; f. 1-3, 5, 8-10: sinais de amassado; vincos; 
sinais de fungo; f. 2: último verso do poema Cena cortado; f. 4: rasgamentos na borda superior à direita, canto inferior direto rasgado; f. 5: pequenos rasgamentos nas bordas; f. 6: borda superior rasgada; f. 7: pequeno rasgamento nas bordas direita e esquerda; f. 8-9: pequeno rasgamento nas bordas direita e superior; f. 10: pequenos rasgamentos nas bordas direita e inferior; manchas de carbono; escrita no anverso; rasuras a máquina; fólios numerados pela pesquisa: (1)-(1) (1).

Nota MA a lápis preto: verso da f. 10: "Versos de Carlos Lacerda".

Supremacia do Espirito:

Dedicatória: “-Ao pensador G.Amado".

"Apertando junto do seio":

Nota CL: traço a tinta preta indicando a continuação da última estrofe na margem esquerda.

Classico:

Dedicatória: "Á memoria empolada de Rui Barbosa, que saiu de | casa morrendo para votar o estado de si | tio".

Notas da pesquisa:

1. Ms na vertente Mário de Andrade mentor.

2. Autoria reconhecida pela Nota MA. A ausência de assinatura corrobora o disfarce, presente na carta de CL a MA, documento que acompanhou o ms, escrita em Vassouras, 2 de fevereiro de 1934, onde está: "Hoje mando uns poemas que me mandaram, assinado MARCOS, que não | sei quem é. Copiei e mando a você, pedindo palpite seu, logo que | possível, para ver si concorda com o meu". (Ref.: série Correspondência Mário de Andrade; sub-série: Correspondência passiva: MA-C-CPL, $n^{\circ} 3832$ ). Lacerda usou o pseudônimo Marcos.

3. Data e local do ms atestados com base na acarta referida.

Estudo genético:

1. No arquivo MA os textos, com exceção de "O pernilongo" e Supremacia do Espírito, apresentam-se em uma única versão, A, cópia em datiloscrito que mostra, em Boia, Feriado, Demagogia, Berceuse, Cena ("No girau entre as quatro paredes"), "Canta nos teus olhos uma alegria", Liberdade dos presos proletarios, Imprensa livre..., Jardim fechado, "Os olhos do avião", Paisagem triste, Amor e Boletim internacional 1 etapa na escritura, e nos demais poemas, 2 etapas na escritura: a-a $a_{1}$ :

a: datiloscrito completo;

$\mathrm{a}_{1}$ : rasuras a máquina.

2. "O pernilongo" e Supremacia do Espirito são versões do mesmo poema. O primeiro foi classificado pela pesquisa como versão A e o segundo como B; a única variante é o acréscimo do título na versão B.

3. Os títulos repetidos, Cena e Classico correspondem a 4 poemas autônomos, não a versões. 
MA - MOE, 185

LACERDA, Carlos (Carlos Frederico Werneck Lacerda 1914-1977)

185. Quilombo de Manuel Congo; crônica (MAm)

[Rio de Janeiro, ant. set. 1935]

Datiloscrito original fita azul e vermelha; papel branco; filigrana; 41 folhas; f. 2-29: $27,8 \times 21,5 \mathrm{~cm}$, f. $30-40: 28,0 \times 21,4 / 21,6 \mathrm{~cm}$ com variações em mm na largura; rasgamentos nas margens; f. 5: canto superior esquerdo amassado; f. 2, 19, 37: rasgamento na borda esquerda; vincos; sinais de fungo; 2 furos para arquivamento; marcas de digital; escrita no anverso; f. 41: visto do escritor a lápis preto; folhas numeradas pelo escritor: $3-42$; rasuras a máquina, a lápis preto e a tinta roxa; fólios numerados pela pesquisa: (1)-(4) (1). F. 1: capa em papel branco, timbrado: "Prefeitura do Municipio de S. Paulo | DEPARTAMENTO DE CULTURA"; 32,6 x 22,1/22,5 cm; borda esquerda recortada; sinais de fungo; escrita no verso.

Nota MA a lápis azul e vermelho: f. 1: "Originais | do | 'Quilombo de Manuel Congo' $\mid$ de | Carlos Lacerda | (faltam as 2 páginas | iniciais, perdidas)”.

Notas da pesquisa:

1. Ms na vertente Mário de Andrade mentor.

2. Data atestada com base na dedicatória do livro de CL Quilombo de Manuel Congo (Rio de Janeiro, R.A. editora, 1935), publicado com o pseudônimo MARCOS, do qual a biblioteca de MA guarda dois exemplares; um deles com a dedicatória: "Mario; | este é o teu | livro; | (bis) | este é o teu | amigo | Carlos | Rio 27 set 35".

Estudo genético:

1. No arquivo MA o texto apresenta-se em uma única versão, A, rascunho em autógrafo que mostra 5 etapas na esrcitura: $a-a_{1}-a_{2}-a_{3}-a_{4}$ :

$\mathrm{a}-\mathrm{a}_{1}$ : datiloscrito completo, em fita azul e vermelha;

$\mathrm{a}_{2}$ : rasuras a máquina

$\mathrm{a}_{3}$-a $\mathrm{a}_{4}$ : rasuras a lápis e a tinta roxa, sem possibilidade de identificar a ordem dessas etapas

MA - MOE, 186

LACERDA, Carlos (Carlos Frederico Werneck Lacerda 1914-1977)

186. $O$ desafio da adolescência; peça teatral (MAm)

[Rio de Janeiro], 1940, 18-19 maio 1941

Datiloscrito, cópia carbono preto; papel branco; 28 folhas; f. 1, 6-10, 12-28: 28,0 x 21,6 cm, f. 2-5, 11: 27,9 x 21,5 cm; f. 1: rasgamentos nas bordas e na margem esquerda; f. 1, 28: 3 tiras de durex grudadas na margem esquerda; f. 2: rasgamentos nas bordas esquerda e direita; f. 2-28: 3 furos de grampo na margem esquerda; f. 28: rasgamentos na borda esquerda e ferrugem de grampo; vincos; sinais de fungo; manchas de carbono; f. 5, 11, 14: texto da última linha cortado; escrita no anverso; folhas numeradas pelo escritor: 1-14, 16-24, 26-28; f. 1: folha de rosto com título e 
sub-título: "O DESAFIO DA ADOLESCENCIA | Féerie histórico-sentimental em 3 atos e numerosas porém curtas cenas."; f. 2: etiqueta de identificação do volume na biblioteca MA: “C/I/ h-op. 24/157”; rasuras: a máquina, f. 11: a tinta preta; fólios numerados pela pesquisa: (1)-(2) (8). Notas CL: f. 1: “f. 28: “-Começada em fim de 1940 | acabada em 18 e 19 maio 1941".

Notas MA a lápis vermelho: f. 1: indicação de autoria: "Carlos Lacerda", grifo no título e observação: "(por entre opúsculos)".

\section{Notas da pesquisa:}

1. Ms na vertente Mário de Andrade mentor.

2. Local atestado pela pesquisa; CL vivia no Rio de Janeiro; sua correspondência com MA teve início em junho de 1933, prolongando-se até janeiro de 1945, isto é, até o final da vida de Mário, em 25 de fevereiro desse ano.

3. Na carta do Rio de Janeiro, 20 de maio de 1941, CL trata do envio do ms: "Por castigo, mando-lhe cópia, isto é, mandarei si houver tempo da copia-la, de uma féerie | divertissement (ai de mim) [...]. Gostaria si você dissesse apenas que o gênero é viável (isto é, si é suscetível de | ter vida, de transmitir alguma coisa), ou si é fracasso absoluto". (Ref.: série Correspondência Mário de Andrade; sub-série Correspondência passiva: MA-C-CPL, $\mathrm{n}^{\circ}$ 3849)

\section{Estudo genético:}

1. No arquivo MA o texto apresenta-se em uma única versão, A, o datiloscrito em cópia carbono que mostra 3 etapas na escritura: $a-a_{1}-a_{2}$

a: datiloscrito completo;

$\mathrm{a}_{1}$ : rasuras a máquina;

$\mathrm{a}_{2}$ : rasura a tinta preta.

\section{MA-MOE, 187}

\section{LACERDA, Carlos (Carlos Frederico Werneck Lacerda 1914-1977)}

187. $O$ Rio; teatro (MAc)

[Rio de Janeiro, ant. 13 nov. 1941]

Datiloscrito original, fita preta; datiloscrito, cópia carbono preto; autógrafo a tinta preta; papel branco; 8 folhas; rasuras a máquina, a lápis preto, verde, vermelho e azul, a tinta preta; escrita no verso do ms A revolução praieira de Moacyr Weneck de Castro (V. MA-MOE, 112).

\section{Notas da pesquisa:}

1. Ms na vertente Mário de Andrade colecionador.

2. Local e data atestados com base na carta CL a MA, do Rio de Janeiro, 13 de novembro de 1941, na qual se lê: "Tenho agora remexido melhormente em papéis desencontrados, desarrumados nesses | encontrões que se vai tomando na vida. Por isso mesmo, tenho conseguido encontrar | os originais de 'O rio', que você certa vez pediu tanto por carinho quanto por mania. | Mando agora, junto com esta carta, algumas paginas, atrás das quais - ou na frente das | quais, não me lembro mais - o Moacir escreveu outros 
originais, os do estudo dele | sobre a Praieira. Assim, fica valorizado o original do ' $\mathrm{O}$ rio'... O resto mandarei | assim que encontrar, e será dentro de poucos dias”. (Ref.: série Correspondência Mário de Andrade - sub-série Correspondência passiva; MA-C-CPL, $\left.\mathrm{n}^{\circ} 3850\right)$

3. A peça $O$ Rio saiu em 1943, em São Paulo, na tiragem especial promovida por bibliófilos, composta de 200 exemplares em papel "buffon" $54 \mathrm{~kg}$, numerados e assinados pelo autor, e 20 marcados de A a T, ilustrada por Lívio Abramo em linóleo, trazendo ilustrações de Walter Levy nas páginas de abertura dos atos. Na biblioteca de MA acha-se o exemplar A, marcado e assinado por CL, volume que não guardou as ilustrações excedentes em papel arroz, também marcadas e assinadas por CL, declaradas na edição.

\section{MA - MOE, 188}

LESSA, Orígenes（Orígenes Temudo Lessa 1903-1986)

188. $O K$; teatro (MAc)

[S/ local, s/ data]

Autógrafo a tinta preta; papel branco, filigrana; 145 folhas; f. 1: 32,5/32,6 x 22,6 cm; f. $2-69,72-76,134-138: 27,9 / 28,0$ x 21,4 cm, f. 70-71, 77-133, 139-145: 26,4 x 20,4/20,5 cm; pequenos rasgamentos nas bordas; f. 1: rasgamentos nas bordas superior, direita e inferior; f. 2: canto superior direito rasgado; f. 62, 105: rasgamento na borda superior; f. 76: canto inferior direito rasgado; f. 81: borda direita superior rasgada; folhas com as bordas amassadas; f. 2-33: vincos; sinais de fungo; f. 2, 36-37, 75, 77, 89-90, 105-106, 128-129: ferrugem de clipe; f. 3, 84: tinta do autógrafo borrada; manchas de tinta preta; escrita no anverso, f. 98: escrita no anverso e no verso; f. 1 capa com Nota MA; folhas numeradas desordenadamente pelo escritor; rasuras a tinta preta; fólios numerados pela pesquisa: (1)-(1) (4) (5). Nota OL: a tinta preta no verso da f. 18: conta.

Notas MA a lápis vermelho: f. 1: "Origenes Lessa | Nasceu um Heroi | (1º titulo: O.K.) | Peça montada por Dulci- | na e Odilon. | Publicada em 'Vamos Ler' | originais"; f. 57: sinal ao lado da rasura "(compenetrado.)"; f. 46-65: correção da numeração das folhas.

Notas da pesquisa:

1. O ms enquadra-se na vertente Mário de Andrade colecionador.

2. Em 1945, OL publicou o livro O.K. América: cartas de Nova York (Rio de Janeiro, Leitura), mas não se trata de peça de teatro.

\section{Estudo genético:}

1. No arquivo MA o texto apresenta-se em uma única versão, A, o autógrafo a tinta preta, versão do escritor que mostra 2 etapas na escritura: $\mathrm{a}_{1}-\mathrm{a}_{2}$

$\mathrm{a}_{1}$ : autógrafo completo

$\mathrm{a}_{2}$ : rasuras a tinta preta 
MA - MOE, 189

\section{LIMA, Cláudio de Araújo}

189. Babel; romance (MAm)

[Rio de Janeiro], 1940

Datiloscrito, cópia carbono preto; datiloscrito original fita preta: f. 1; papel branco, filigrana: "VICTORIA | INDUSTRIA BRASILEIRA"; 148 folhas; 31,7 x 21,9 cm, com variações em $\mathrm{mm}$; rasgamento nas bordas; f. 1: vinco vertical na margem esquerda; sinais de fungo; escrita no anverso; folhas numeradas pelo escritor: 3-149; f. 1: folha de rosto com autoria, título e data: "Claudio de Araujo Lima | BABEL | 1940"; rasuras a máquina e a lápis preto; fólios numerados pela pesquisa: (1)-(1) (4) (8).

Nota MA a lápis preto na f. 28: sinal de interrogação sobre a palavra "tamborilar".

\section{Notas da pesquisa:}

1. Ms na vertente Mário de Andrade mentor.

2. MA agregou à sua correspondência passiva o bilhete de CAL, que acompanhou o ms; o [Rio de Janeiro], sem data,: "Sr. Mario de Andrade: tomei liberda- | de enviar-lhe o original de que lhe falava o | nosso Rosario Fusco. É verdade que esse | bom amigo, ao se referir à minha primeira | tentativa literária, [...]. Leia-o pois, não como amigo do magnifico Fusco, mas como critico, visto como a sua opinião terá para mim uma significação de todo singular." (Ref.: série Correspondência Mário de Andrade - subsérie Correspondência passiva; MA-C-CP, $\mathrm{n}^{\circ}$ 4114).

Estudo genético:

1. No arquivo MA o texto apresenta-se em uma única versão, A, o datiloscrito em cópia carbono que mostra 3 etapas na escritura: $a-a_{1}-a_{2}$ :

a: datiloscrito completo;

$\mathrm{a}_{1}$ : rasuras a máquina;

$\mathrm{a}_{2}$ : rasuras a lápis preto.

2. A versão A confrontada com a versão B: Babel. São Paulo, S. E. Panorama Ltda., s/d. Há poucas variantes entre ambas versões.

\section{MA - MOE, 190}

LIMA, Jorge de (Jorge Mateus de Lima 1895-1953)

190. Louvado; poesia (MAd)

Maceió, maio 1929

Datiloscrito, cópia carbono preto; papel branco, filigrana; 1 folha; 33,0 x 22,2 cm; borda direita recortada; vincos; sinais de fungo; escrita no anverso; autoria: "(DO POETA JORGE DE LIMA)"; local e data na margem inferior: "Maceió, maio, 1929."; rasuras a máquina; fólio numerado pela pesquisa: (1). Nota JL na margem direita: bilhete a MA: forma de tratamento: "Querido Mario,"; autógrafo a tinta preta; conteúdo: andamento de trabalho com cocos; lembranças. 
Notas da pesquisa:

1. Ms na vertente Mário de Andrade no diálogo interpares.

2. Louvado saiu em Novos poemas (Rio de Janeiro, Pimenta de Melo, 1929).

3. Na biblioteca de MA está um exemplar do livro com a dedicatória: "Ao querido Mario, | com a admiração grandissima | com o carinho do | Jorge de Lima | Rio, 31.7.929”.

Estudo genético:

1. No arquivo MA o poema apresenta-se em uma única versão, A, cópia carbono de datiloscrito que mostra 2 etapas na escritura: $a-a_{1}$ :

a: datiloscrito completo;

$\mathrm{a}_{1}$ : rasuras a máquina.

2. A versão A confrontada com a versão B em Novos poemas (ed. cit.) mostra variantes.

\section{MA - MOE, 191}

LIRA, Mariza (1899-1971)

19. A cruz vermelha; ensaio historiografia (MAm)

Curitiba, 28 nov. 1942

Datiloscrito, cópia carbono preto; papel branco; 28 folhas; 32,7 x 22,0 cm, com variação em mm; vinco; sinais de fungo; manchas de carbono; f. 1-2, 26-28: marca de ferrugem na margem esquerda; f. 1, 28: rasgamento; f. 14: furo na margem esquerda; f. 24-27: marcas de amassamento; escrita no anverso; folhas numeradas pela escritora: 2-28; f. 28: local, data e autoria: "Curitiba, 28 de Novembro de 1942. | (a) Mariza Lira | Maria Luiza Lira de Araujo Lima"; rasuras a máquina; fólios numerados pela pesquisa: (1)-(2) (8). Notas ML: em autógrafo a tinta preta: "Trabalho apresentado à prova | final de exame"; em datiloscrito: a baixo do título: "Organizado por determinação do Cel. Médico | Raul da Cunha Bello pela aluna do Curso de | Samaritanas Socorristas - MARIZA LIRA".

Notas da pesquisa:

1. Ms na vertente Mário de Andrade mentor.

2. ML enviou A cruz vermelha a MA junto com o bilhete, de Curitiba, em cartão de visita, data atestada como [anterior a 20 de fevereiro de 1943], acompanhado do ms A cruz vermelha. No bilhete está: "Mariza Lira [impresso] cumprimenta e oferece esses trabalhinhos pedindo desculpas pelos erros de origem e da falta de revisão." [autógrafo a tinta preta]. (Ref.: série Correspondência Mário de Andrade - sub-série Correspondência passiva; MA-C-CPL, $\mathrm{n}^{\circ} 4242$; V. análise documentária de Folklore do Paraná: MA-MOE, 192).

\section{Estudo genético:}

1. No arquivo MA o ms apresenta-se em uma única versão, A, o datiloscrito na cópia que mostra duas etapas na escritura: $a-a_{1}$ :

a: datiloscrito completo;

$\mathrm{a}_{1}$ : rasuras a máquina. 
MA - MOE, 192

LIRA, Mariza (1899-1971)

192. Folklore do Paraná; ensaio folclore (MAm)

Curitiba, 30 dez., 1942

Datiloscrito, cópia carbono preto; papel branco; 14 folhas; 30,0 x 23,4 cm, com variação em mm; f. 14: rasgamento na borda direita; vinco; sinais de fungo; furo de grampeador na margem esquerda; f. 1: ferrugem de grampo na margem esquerda; $f$. 14: rasgamento; escrita no anverso; f. 14: local e data na margem inferior: "(Curitiba, -3 horas da madrugada. 30 de Dez $^{\circ}$ de 1942"; folhas numeradas pela escritora: 2-14; rasuras: a máquina, f. 1: a tinta preta; fólios numerados pela pesquisa: (1)-(1) (4). Notas ML: f. 1: em autógrafo a tinta preta: dedicatória: "Para o Prof. Mario de Andrade | julgar melhor a | aluna | Mariza Lira"; em datiloscrito, abaixo do título: "Comunicação folklorica feita aos intelectuais | paranaenses, no Clube Curitibano, na noite de 5 | de janeiro de 1943, pela folklorista carioca | MARIZA LIRA.".

Notas MA: a lápis preto: sugestões de substituição, anotação: f. 9: margem esquerda: "Amarrilho | mágico", grifo em palavra; a lápis vermelho: grifos em palavras, traços destacando versos e estrofes, e anotação: f. 9: "Saúde".

Notas da pesquisa:

1. Ms na vertente Mário de Andrade mentor.

2. ML remeteu Folklore do Paraná a MA junto com o bilhete, de Curitiba, em cartão de visita, data atestada como [anterior a 20 de fevereiro de 1943], acompanhado do ms $A$ cruz vermelha. No bilhete está: "Mariza Lira [impresso] cumprimenta e oferece esses trabalhinhos pedindo desculpas pelos erros de origem e da falta de revisão." [autógrafo a tinta preta]. (Ref.: série Correspondência Mário de Andrade - sub-série Correspondência passiva; MA-C-CPL, $\mathrm{n}^{\circ}$ 4242). (V. análise documentária de A cruz vermelha: MA-MOE, 191).

Estudo genético:

1. No arquivo MA o ms apresenta-se em uma única versão, $\mathrm{A}$, o datiloscrito na cópia que mostra 3 etapas na escritura: $a_{1}-a_{2}-a_{3}$

a: datiloscrito completo;

$\mathrm{a}_{1}$ : rasuras a máquina;

$\mathrm{a}_{2}$ : rasura a tinta preta.

MA - MOE, 193

LISBOA, Henriqueta (1904-1985)

193. Infância; Ausência do anjo; Prisioneira da noite; A cidade mais trise; poesia (MAm)

[Belo Horizonte, ant. 19 mar. 1941]

Datiloscrito, cópia carbono azul; papel branco, filigrana; 4 folhas; 33,1 x 22,1 cm; vincos; sinais de fungo; escrita no anverso; assinatura a máquina embaixo dos títulos: "Henriqueta Lisboa"; assinatura a tinta preta: "Henriqueta Lisboa"; rasuras a 
máquina, a tinta preta e a lápis preto; fólios numerados pela pesquisa: (1)-(4). Nota HL: f. 1 à margem inferior: "Tenho alguns nestes diapasão. Gosta, Mário?".

Notas da pesquisa:

1. Ms na vertente Mário de Andrade mentor.

2. Os poemas encontram-se publicados em Prisioneira da noite (Rio de Janeiro, Civilização Brasileira, 1941). MA guardou 2 exemplares do livro, um deles traz a dedicatória: "A Mario de Andrade, | com a mais viva admiração de | Henriqueta Lisboa. | Belo Horizonte, 19.3.1941".

3. A data do ms foi atestada com base na época da dedicatória.

4. MA conheceu HL em sua viagem a Belo Horizonte, em 1939.

5. Sobre Henriqueta Lisboa, MA escreveu "Coração magoado" para o Diário de Notícias do Rio de Janeiro, em 11 de julho de 1941, artigo que integra $O$ empalhador de passarinho (São Paulo, Livraria Martins Editora, 1946).

\section{Estudo genético:}

1. No arquivo MA os poemas Ausência do anjo, Prisioneira da noite e A cidade mais trise apresentam-se em 2 versões, sendo os acima registrados considerados, pela pesquisa, versão A, cópia no datiloscrito (V. análise documentária da versão B, MA-MOE, 194).

2. Infância mostra 2 etapas na escritura: $\mathrm{a}-\mathrm{a}_{1}$ :

a: datiloscrito completo;

$\mathrm{a}_{1}$ : rasura a lápis preto.

3. Ausência do anjo, mostra 2 etapas na escritura: $\mathrm{a}^{-\mathrm{a}_{1}}$ :

a: datiloscrito completo;

$\mathrm{a}_{1}$ : rasura a tinta preta.

4. Prisioneira da noite, $A$ cidade mais trise mostram 3 etapas na escritura: $\mathrm{a}_{-} \mathrm{a}_{1}-\mathrm{a}_{2}$ :

a: datiloscrito completo;

$\mathrm{a}_{1}$ : rasuras a máquina;

$\mathrm{a}_{2}$ : rasuras a tinta preta.

5. Infância mostra 2 etapas na escritura: $\mathrm{a}-\mathrm{a}_{1}$ :

a: datiloscrito completo;

$\mathrm{a}_{1}$ : rasura a lápis preto.

6. A versão A de Ausência do anjo apresenta variante em relação à versão $\mathrm{B}$, no ms, e à versão C no livro Prisioneira da noite (ed. cit.); a versão A dos poemas Prisioneira da noite e A cidade mais trise não apresenta alterações em relação à versão $\mathrm{B}$, no ms.

\section{MA - MOE, 194}

\section{LISBOA, Henriqueta (1904-1985)}

194. Consciência; Ausência do anjo; Prisioneira da noite; A cidade mais trise; A misteriosa presença; Mensagem; Parabóla; Pastor; Inspiração que se perdeu; Flor; Convite; Repouso; poesia (MAm)

[Belo Horizonte, ant. 19 mar. 1941]

Datiloscrito, original fita preta; papel branco; 18 folhas; 32,6/32,7 x 22,1 cm; f. 4-5: rasgamento na borda direita; f. 15: borda superior amassada com rasgamento; f. 18: 
pequenos rasgamentos na borda superior; vinco; sinais de fungo; f. 2-7, 9-18: marca de clipe na borda superior à esquerda; f. 1, 18: ferrugem de clipe no verso da folha; escrita no anverso; autoria em baixo dos títulos: "Henriqueta Lisbôa"; rasuras a tinta preta e a máquina; fólios numerados pela pesquisa: (1)-(1) (8). Notas MA.

Consciência:

Nota MA a lápis preto: "Não é do "Prisioneira| da noite"”.

Ausência do anjo:

Nota MA a lápis preto: f. 2: escrita no anverso e no verso: longo comentário sobre o poema e o estilo da escritora.

Prisioneira da noite:

Notas MA a lápis vermelho: f. 1: comentário: "muito historiado na | fluidez do poema”; a lápis preto: f. 2: sugestão de suprimir o v. 7 na $5^{\text {a }}$ estrofe (“- Ó vós que sabeis"): "tirar isto, é feio", e longo comentário sobre o poema.

A cidade mais triste:

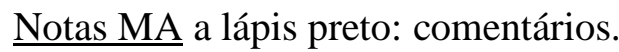

A misteriosa presença:

Notas MA a lápis preto: comentário e sugestão de substituição de palavra.

Mensagem:

Notas MA: f. 1: grifo na expressão "do oceano" com sugestão de substitição a lápis preto: "dos oceanos"; outra sugestão de substituição: "quanto" por "quando".

\section{Parabóla:}

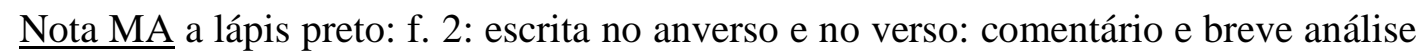
do poema.

Pastor:

Nota MA a lápis preto: sugestão de substituição: pronome "ele" por "ela".

Inspiração que se perdeu:

Notas MA a lápis vermelho e azul: grifo em palavras.

Convite:

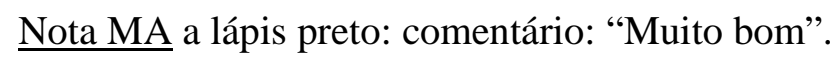

Repouso:

Nota MA a lápis preto: comentário.

Anexos:

1) Capa em papel branco; 33 x 19,5 cm; sinais de fungo; fólio numerado pela pesquisa: (1). Nota MA a lápis vermelho e azul: "Henriqueta Lisboa | Poesias". 
2) Lista feita por MA com os títulos dos poemas do livro Prisioneira da noite, de HL: autógrafo a lápis preto; papel beje; 1 folha; 32,0/32,4 x 22,0/22,1 cm; pequenos rasgamentos nas bordas; sinais de fungo; escrita no anverso; traço vertical a lápis vermelho dividindo o espaço da folha em duas colunas; fólio numerado ela pesquisa: 1.

Notas MA a lápis azul: grifo no título dos poemas que recebera de HL.

Notas da pesquisa:

1. Ms na vertente Mário de Andrade mentor.

2. Ausência do anjo, Prisioneira da noite, A cidade mais trise, A misteriosa presença, Mensagem, Parabóla, Pastor, Inspiração que se perdeu, Flor e Convite foram publicados em Prisioneira da noite (ed. cit.). MA guardou 2 exemplares do livro, um deles com a dedicatória: "A Mario de Andrade, | com a mais viva admiração de | Henriqueta Lisboa. | Belo Horizonte, 19.3.1941".

3. Data do ms atestada com base na época da dedicatória do livro.

4. Sobre Henriqueta Lisboa, MA escreveu "Coração magoado" (V. MA-MOE, 193, nota $5)$.

Estudo genético:

1. No arquivo MA Ausência do anjo; Prisioneira da noite; A cidade mais trise apresentam-se em 2 versões, sendo os acima registrados considerados, pela pesquisa, versão B, passada a limpo no datiloscrito (V. análise documentária da versão A: MAMOE, 193). Os demais poemas apresenta-se em uma única versão, A.

2. Consciência, A misteriosa presença, Parabóla, Flor e Repouso mostram 1 etapa na escritura.

3. A cidade mais trise e Convite mostra 2 etapas na escritura: $\mathrm{a}_{-} \mathrm{a}_{1}$ :

a: datiloscrito completo;

$\mathrm{a}_{1}$ : rasuras a máquina.

4. Ausência do anjo, Prisioneira da noite, Mensagem, Pastor, Inspiração que se perdeu mostram 2 etapas na escritura: a-a a $_{1}$

a: datiloscrito completo;

$\mathrm{a}_{1}$ : rasuras a tinta preta.

\section{MA - MOE, 195}

LISBOA, Henriqueta (1904-1985)

195. Caixinha de música e poesias; poesia (MAm)

[Belo Horizonte, ant. 9 out. 1941]

Datiloscrito, cópia carbono azul; papel branco, filigrana; 45 folhas; 25,4/26,5 x 20,5/20,6 cm a 28,9 x 21,6 cm, f. $6: 15,5 / 15,7$ x 21,6 cm, f. $8: 12,8 / 13,0$ x 21,6 cm; f. 6: borda superior recortada; f. 8: borda inferior recortada com tesoura; f. 29: pequenos rasgamentos na borda direita; vincos; poucos sinais de fungo; f. 2-3, 20: margem superior esquerda: marca de clipe; escrita no anverso; assinatura a máquina: abaixo do título: "Henriqueta Lisboa" ou "H. Lisboa", sobre o título : "De H. Lisboa"; f. 45: índice com os títulos dos poemas no ms; rasuras a máquina e a tinta preta; fólios 
numerados pela pesquisa: (1)-(4) (5). Nota HL: f. 20: no final do poema Anjo bom: “(De Caixinha de Música)".

Notas MA a lápis preto: numeração dos poemas: 1-45, comentários, sugestão de alteração, f. 45: pequenos traços na margem esquerda destacando os títulos: Pirilampos, Paineira, Mariposas; a lápis vermelho: grifo em palavra; f. 39: nota a lápis apagada: "Este não deve ser do grupo"; f. 3: sobre a a última estrofe do poema Caixinha de música ("Boneca de louça dansa | com tres notinhas de piano"): redige 2 notas: à lápis preto à margem direita: "Há um lado explicativo | neste dístico final que | me desagrada, talvez por | um leve ranço didatico", à margem esquerda à lápis vermelho: "Retirado por|H.L.".

O ms apresenta os títulos: O menino poeta, Caixinha de música, Coraçãozinho, Cantiga de nenem, Tico-tico, Cavalino de pau, Segrêdo, Hortelão, Corrente de formiguinhas, Tempestade, Patinhos na lagôa, Jardim, Pomar, Varzea, Coração, Os quatro ventos, $O$ menininho do velocípede, Estrelinha do mar, Anjo bom, Copo de leite, Mamãezinha, Charanga, Castigo, Morena e Clara, Ronda de estrêlas, Ronda de flores, As borboletas, O tempo é um fio, Castelos, Os rios, Palavras, Boizinho velho, Paineira do meu quintal, Aquário, Arco-íris, Colégio, Passos, Eco, Jardim celeste, Frio e sol, Ciranda, Crepúsculo com tres meninas, Casa, Maninha.

Anexo:

Capa feita por MA com autógrafo a lápis vermelho e azul; papel branco; 1 folha; 32,9 x 20,4/21,1 cm; borda esquerda recortada com tesoura; sinais de fungo; marcas de amassado; escrita no anverso; indicação de autoria e título: "Henriqueta Lisboa | Caixinha de Música | e | Poesias"; fólio numerado pela pesquisa: (1).

Notas da pesquisa:

1. Ms na vertente Mário de Andrade mentor.

2. Local e data atestados com base na carta de HL a MA, de Belo Horizonte em 9 de outubro de 1941, na qual se lê: "Alguem escreverá êsse livro, querido Mário. Amanhã, daqui a 10, 20 anos. Talvez o "menino poeta" do meu poemazinho que aí vae. Veja se gosta. [...]. Depois desses versos, repentinamente, dei de ficar preocupada com os pequeninos futuros poetas do Brasil. E comecei a escrever um livro para êles. Em duas semanas o livro está quase pronto. Eu mesma estou espantada. Não sei se serão, de fato, versos para crianças. Escrevo-os com todas as minhas reservas de puerilidade e embrevecimento deante da vida. É a poesia que eu quisera ter encontrado aos 12 anos. Para não perturbar a inspriração, deixo para depois a escôlha, o critério de seleção em frente aos problemas da psicologia infantil. Envio-lhe alguns juntamente com amostras de outro livro - sério- só para gente grande" (Ref.: série Correspondência Mário de Andrade - sub-série Correspondência passiva; MA-C-CPL, $\mathrm{n}^{\circ}$ 4264).

3. Os poemas no ms foram publicados em $O$ menino poeta (Rio de Janeiro : [Bedeschi], 1943). Há 2 exemplares do livro na biblioteca MA, um deles com a dedicatória: "A Mário de Andrade, | lembrança do coração. | Henriqueta Lisboa | Belo Horizonte, 1943”. 
Estudo genético:

1. No arquivo MA o ms apresenta-se em uma única versão, A, que mostra em Hortelão, Tempestade, Colégio, Passos, crepúsculo com tres meninas 2 etapas na escritura: a-a : $_{1}$ a: datiloscrito completo; $\mathrm{a}_{1}$ : rasuras a tinta preta.

2. Os demais poemas mostram 1 etapa na escritura.

3. As Notas MA foram redigidas em dois momentos distintos: a lápis preto logo após o recebimento do ms e a lápis vermelho após a publicação do livro $O$ menino poeta (ed. cit.).

4. Na versão A confrontada com a versão B em Caixinha de música (ed. cit.), os poemas Tico-tico, Cavalino de pau, Mamãezinha, Charanga, Castigo, Ronda de estrêlas e As borboletas não apresentam variantes; os demais poemas apresentam variantes.

5. As sugestões nas Notas MA foram acatadas por HL na versão B.

\section{MA - MOE, 196}

LISBOA, Henriqueta (1904-1985)

196. As madrugadas; Sono; Os carneirinhos; Siderúrgica; Nauta; Lágrima; Laços; Sabedoria; Esperança; Floripa; Caboclo dágua; poesia (MAm)

[Belo Horizonte, post. 9 out. 1941]

Datiloscrito, cópia carbono azul; papel branco, filigranas: "VICTORIA | INDUST. BRASIL." e "MONROE BOND"; 13 folhas; 26,7 x 20,7 cm, com variações em mm; f. 1-2: sinal de clipe na borda superior à esquerda; vincos; sinais de fungo; escrita no anverso; assinatura a máquina abaixo dos títulos: "Henriqueta Lisboa": f. 1, 4 e "H. Lisboa": f. 2-3, 5-13; rasuras a máquina e a tinta preta; fólios numerados pela pesquisa: (1)-(1) (2). Notas MA.

Os carneirinhos:

Nota MA a lápis vermelho: "Retirado do livro".

Laços:

Nota MA a lápis preto: comentário sobre a $6^{\mathrm{a}}$ estrofe: "Talvez esta | quadra diga demais. | tudo o resto é tão Tênue".

Sabedoria:

Notas MA a lápis preto: "Não gosto da parábola. | Principalmente com o | titulo que tem, franqueza | parece que os sabios são os | doutores e não Jesus."; a lápis vermelho: "Retirado do livro".

Esperança:

Nota MA a lápis preto: "Não gosto muito. Alegorico. | Facil de perceber a alegoria. | Excessiva conciência logica". 
Notas da pesquisa:

1. Ms na vertente Mário de Andrade mentor.

2. Os poemas foram publicados em $O$ menino poeta (ed. cit.). Há 2 exemplares do livro na biblioteca MA, um deles com a dedicatória: "A Mário de Andrade, | lembrança do coração. | Henriqueta Lisboa | Belo Horizonte, 1943".

3. Data atestada com base na carta de HL a MA, de Belo Horizonte, 9 de outubro de 1941, à qual foi anexada a série de poemas intitulada Caixinha de música (V. MA-MOE, 195, nota 2$)$.

Estudo genético:

1. No arquivo MA o ms apresenta-se em uma única versão, A, a cópia no datiloscrito que mostra em Os carneirinhos, Siderúrgica, Nauta, 1 etapa na escritura, e em As madrugadas; Sono; Lágrima, Laços, Sabedoria, Esperança, Floripa 2 etapas na escritura: $\mathrm{a}-\mathrm{a}_{1}$ a: datiloscrito completo;

$\mathrm{a}_{1}$ : rasuras a tinta preta

2. As Notas MA foram redigidas em dois momentos distintos: a lápis preto, logo após o recebimento do ms; a lápis vermelho após a publicação do livro $O$ menino poeta (ed. cit.).

3. Na versão A confrontada com a versão B em $O$ menino poeta (ed. cit.), os poemas Madrugada, Sono, Conciência, não apresentam variantes.

\section{MA - MOE, 197}

LISBOA, Henriqueta (1904-1985)

197. Poesia de Mário de Andrade.

[Belo Horizonte], 1943

Autógrafo a tinta preta; papel branco, bordas irregulares; papel dobrado ao meio formando 2 folhas; 19,5 x 16,1 cm; escrita: f. 1: no anverso e no verso, f. 2 : no anverso; assinatura e data no final do poema: "Henriqueta Lisboa | 1943"; fólios numerados pela pesquisa: (1)-(2).

Nota da pesquisa:

1. Ms na vertente Mário de Andrade mentor.

Estudo genético:

1. No arquivo MA o ms apresenta-se em uma única versão, A, passada a limpo que mostra 1 etapa na escritura: 
MA - MOE, 198

LISBOA, Henriqueta (1904-1985)

198. Madalena; Titia; Capim melado; poesia (MAm)

[Belo Horizonte, jan. 1944]

Datiloscrito, cópia carbono azul; papel branco, filigrana: "MONROE BOND"; 3 folhas; 26,4/26,5 x 20,5/20,6 cm; vincos; sinais de fungo; escrita no anverso; rasura a máquina; autoria a baixo do título: "H. Lisboa"; fólios numerados pela pesquisa: (1)(3). Nota MA.

Madalena:

Nota MA a lápis vermelho: "Retirado do livro".

Anexo:

Capa improvisada por MA; papel branco; 1 folha; 32,8/33,0 x 21,7/22,0; borda esquerda recortada com tesoura; pequenos rasgamentos na borda superior; sinais de fungo; escrita no anverso; fólio numerado pela pesquisa: (1). Nota MA a lápis azul e vermelho: "Henriqueta Lisboa | Inéditos em | I-1944.

Notas da pesquisa:

1. Ms na vertente Mário de Andrade mentor.

2. Data atestada com base na Nota MA na capa: "Inéditos em | I-1944".

Estudo genético:

1. No arquivo MA o ms apresenta-se em uma única versão, A, que mostra em Madalena e Capim melado 1 etapa na escritura, e em Titia 2 etapas na escritura: a-a $a_{1}$ :

a: datiloscrito completo;

$\mathrm{a}_{1}$ : rasura a máquina.

MA - MOE, 199

LISBOA, Henriqueta (1904-1985)

199. A face lívida e outros poemas; poesia (MAm)

Belo Horizonte-São Paulo, 9 out. 1944-fev. 1945

Autógrafo a tinta preta e azul; caderno capa dura, estampa azul em altorelevo, cantos arredondados; 19,5 x 13, $7 \mathrm{~cm}$; lombada cinza; marcador de páginas: fita de tafetá azul; miolo: papel branco, pautado: f. 2-151; 152 folhas; 18,8 x 12,5 cm; f. $65: 1$ rasgamento na borda direta superior; escrita no anverso e no verso; f. 2: folha de rosto com título, autoria, local e data: "A Face Lívida | e outros poemas | de | Henriqueta Lisboa | copiados pela autora | para Mário de Andrade | Belo Horizonte | 1944" e etiqueta MA para identificação de livros em sua biblioteca, não preechida; f. 75: o poema Romance do Aleijadinho com dedicatória: "a Mário de Andrade"; f. 87 a 151: em pranco; rasuras a tinta preta; fólios numerados pela pesquisa: (1)-(1) (5) (4). 
Notas HL: f. 82: autógrafo a tinta preta: "Aqui termina o manuscrito | que Henriqueta Lisboa | oferece a Mário de Andrade | em homenagem ao dia | 9 de outubro de 1944"; f. 83: autógrafo a tinta azul: "Continuação | em São Paulo | Fevereiro de 1945".

O ms está dividido em 4 partes: "A face lívida", "Outros poemas", "Poemas da terra". Título dos poemas de "A face lívida" e poema escrito em São Paulo: A face lívida; Lucidez; Imagem; Cântaro; Os lírios; Ressonância; Cantarei a noite e o mar; Inocência; Calado; O anjo da paz; Terra negra; Alivio; Agua marinha; Melancolia; Trigo e joio; As ilhas Aleutas; Alarido; Ouro, incenso e mirra; Canoa; Pérola; Constância; O milagre; Dama de rosto velado; As crianças; O poço; Palmeira da praia; Canção; Longas caminhadas; As virgens; Mar de sombra; Trasflor; A fonte azul; Fraude; Meninos de Viena; Arte; Brisas do mar e da terra; A lua; Orgulho; Eu quero a paz, quero a lua; Chuva; Canção do berço vazio; Natureza; Claro-escuro; Consolação do amigo; "Outros poemas": Poesia de Mário de Andrade; "Poemas da terra": A lenda das pedras verdes; História de Chico Rei; Romance do Aleijadinho; Poesia de Ouro Preto; poema escrito em São Paulo: Elegia.

\section{Notas da pesquisa:}

1. Ms na vertente Mário de Andrade mentor.

2. Versão passada a limpo para presente para presentear Mário de Andrade, iniciada no aniversário dele, 9 de outubro de 1944, e concluída em fevereiro de 1945. HL, que viera a São Paulo para o I Congresso de Escritores Brasileiros, retornou a Belo Horizonte dias antes da morte do amigo, em 25 de fevereiro.

Estudo genético:

1. No arquivo MA o ms apresenta-se em uma única versão, A, cópia passada alimpo que mostra 2 etapas na escritura: $a-a_{1}$ :

a: autógrafo completo;

$\mathrm{a}_{1}$ : rasuras a tinta preta.

MA - MOE, 200

LISBOA, Henriqueta (1904-1985)

200. Exemplo; Mundo da lua; poesia (MAm)

[Belo Horizonte], s/ data

Autógrafo a lápis preto; papel branco; 2 folhas; 22,9 x 15,4 cm; f. 1: pequeno rasgamento na borda superior; f. 2: pequenos rasgamentos nas bordas superior e inferior; vinco; sinais de fungo; escrita no anverso; autoria a baixo do título: "H. Lisboa"; fólios numerados pela pesquisa: (1)-(2).

Nota da pesquisa:

1. Ms na vertente Mário de Andrade mentor. 
Estudo genético:

1. No arquivo MA o ms apresenta-se em uma única versão, $\mathrm{A}$, o datiloscrito que mostra 1 etapa na escritura.

MA - MOE, 201

LOPES, Ascânio (Ascânio Lopes Quatorzevoltas 1906-1929)

201. Argentina; Balada do estudante que foi para a cidade grande; Cena de uma rua afastada; poesia (MAm)

[Cataguases, ant. nov. 1927]

Datiloscrito, original fita vermelha; papel verde, fiiligrana: brasão da República do Brasil; 3 folhas; 22,4 x 16,6 cm; f. 1-2: irregularidades nas bordas superior e esquerda; f. 3: irregularidades nas bordas superior e direita; vincos; sinais de fungo; escrita no anverso; autoria no final dos poemas: "Ascanio Lopes"; rasuras a máquina; fólios numerados pela pesquisa: (1)-(3).

Argentina:

Dedicatória embaixo do título: "Para Maria Clemencia".

Balada do estudante que foi para a cidade grande:

Dedicatória abaixo do título: "Para Dulcelina, minha mãe".

Nota MA a lápis preto na margem inferior à esquerda: "Ribeiro Couto".

Cena de uma rua afastada:

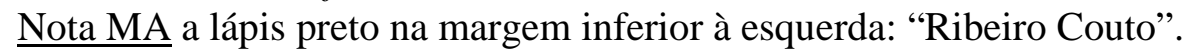

Anexo:

Envelope branco; 12,4 x 15,5 cm; sinais de fungo; fólio numerado pela pesquisa: (1).

Nota MA a lápis preto: "Ascanio Lopes".

Notas da pesquisa:

1. Ms na vertente Mário de Andrade mentor.

2. Local e data atestados com base na carta de AL a MA, de Cataguases, novembro de 1927, onde se lê: "Vão uns poemas para v. | dizer qualquer coisa a respeito". (Ref.: série Correspondência Mário de Andrade, sub-série Correspondência passiva: MA-C-CPL, $\mathrm{n}^{\circ}$ 4335)

3. Balada do estudante que foi para a cidade grande e Cena de uma rua afastada estão publicados em Poemas cronológicos (Cataguases, Verde Editora, 1928). Argentina permaneceu inédito. 
Estudo genético:

1. No arquivo MA o ms apresenta-se em uma única versão, $\mathrm{A}$, o datiloscrito na cópia que mostra 2 etapas na escritura: a-a $a_{1}$ :

a: datiloscrito completo;

$\mathrm{a}_{1}$ : rasura a máquina.

2. A versão A confrontada com a versão B, em Poemas cronológicos (ed. cit.), mostra poucas variantes.

MA - MOE, 202-203

MACHADO, Alcântara (Antonio Castilho de Alcântara Machado de Oliveira, 1901-1935)

202. Brás, Bexiga e Barra Funda; contos (MAc)

São Paulo, 1927

Autógrafo a tinta preta: f. 1-11, 13-30; impresso: f. 12; datiloscrito, cópia carbono roxo: f. 28; papel branco, pautado, filigranas: "ALMASSO" e "VERA CRUZ", timbrado: f. 28, 30: "Machado \& Rudge | Rua Libero Badaró, 87 | $1^{\circ}$ andar - sala 11| Telephone Central, 5098 | São Paulo"; 30 folhas; f. 1-7: 33,1 x 21,8/21,9 cm com variação em mm na largura; f. 8-11: 27,1/27,2 x 21,1 cm, f. 12: 27,7/27,8 x 18,4/19,1 cm, f. 28, 30: $28,1 \times 21,0 \mathrm{~cm}$, f. $29: 25,0 / 28,1 \times 12,9 / 21,0 \mathrm{~cm}$; rasgamentos nas bordas; f. 10: canto superior esquerdo rasgado; f. 1-7, 13-27: borda esquerda cortada; f. 7: mancha de tinta roxa; f. 8: riscos a tinta vermelha; f. 12: irregularidades na borda esquerda, canto superior esquerdo rasgado e riscos a tinta vermelha no verso; f. 13-14: manchas de tinta roxa; f. 15: riscos a tinta vermelha, manchas de tinta preta no verso e risco vertical no verso; f. 21: manchas de tinta preta no verso; f. 22: risco a lápis tinta; f. 24: manchas de lápis; f. 29: canto superior esquerdo recortado com tesoura para retirar o timbre, furos e rasgamentos causados pelo ressecamento do excesso de tinta; vincos; sinais de fungo; escrita: no anverso: 1-30, no verso: f. 1-3, 5-6, 8-11, 13-1418, 20-23, 25-26, 28-30; f. 4, 7, 11, 14, 16, 19, 22, 24, 27, 30: visto do escritor; páginas numeradas pelo escritor; rasuras a tinta preta; Nota AM a tinta preta: f. 14: conta.

O ms apresenta os títulos: Artigo de fundo, Gaetaninho, Carmela, Tiro de guerra ${ }^{\wedge}$ 35, Amor e sangue, A sociedade, Lisetta, Corinthians (2) vs. Palestra (1), Notas biográficas do novo deputado, $O$ monstro de rodas, Armazem Progresso de São Paulo, Nacionalidade.

Amor e sangue:

O conto (f. 12) se apresenta em recorte da revista Novíssima; escrita no anverso e no verso; junto do conto, no anverso, está o poema "A filha do imigrante" de Cassiano Ricardo; rasura a tinta preta: traços diagonais, formando um " $\mathrm{x}$ " invalidando o poema de Cassiano Ricardo.

203. Receita de fudge; receita culinária

[São Paulo], dez. 1930; autógrafo a tinta preta em uma das faces do envelope que acondicionou o ms Brás, Bexiga e Barra Funda para envio a MA; papel amarelo; 1 
folha; bordas recortadas; rasgamentos nas bordas; vincos; sinais de fungo; escrita no anverso; rasura a tinta preta; fólio numerado pela pesquisa: (1). Nota MA a tinta preta, acima da receita: "Originais | do | 'Brás, Bexiga e Barra Funda' | notícias de | São| Paulo | 1927 | oferecidas pelo | autor | António de Alcântara Machado | ao seu confrade | Mário de Andrade | dez. 930 |Acompanhadas desta | receita | de | 'fudge':".

Notas da pesquisa:

1. Ms na vertente Mário de Andrade colecionador.

2. Brás Bexiga e Barra Funda, notícias de São Paulo saiu pela Editorial Hélios (São Paulo, 1927).

3. O conto Amor e sangue, quando publicado na revista Novíssima, teve como título "O drama passional do italianinho".

4. Sobre Brás Bexiga e Barra Funda, notícias de São Paulo, MA escreveu o artigo, "Alcântara Machado", em A Manhã , Suplemento de São Paulo, em 19 de junho de 1927 (Recorte no Arquivo MA).

5. Há um exemplar de Brás Bexiga e Barra Funda, notícias de São Paulo na biblioteca MA com as folhas não separadas pela espátula, com a dedicatória:: "Para o Mario de Andrade, | - grande poeta do Brás | e do resto - | êste livro sem poesia of. O | Alcântara | - março 1927’"

Estudo genético:

1. No arquivo MA o ms apresenta-se em uma única versão, A.

2. A versão impressa de Amor e sangue mostra rasuras a tinta preta.

3. A versão A dos contos ni ms autógrafo mostra 2 etapas na escritura: $\mathrm{a}_{1}, \mathrm{a}_{2}$ $\mathrm{a}_{1}$ : autógrafo completo $\mathrm{a}_{2}$ : rasuras a tinta preta

4. A versão A confrontada com a versão impressa, B, a da $1^{\mathrm{a}}$ edição: MACHADO, Antonio de Alcântara. Brás Bexiga e Barra Funda, notícias de São Paulo. São Paulo, Editorial Hélios, 1927, mostra variantes.

5. A $1^{a}$ edição do livro recebeu edição fac-similar anotada por Cedília de Lara (São Paulo, Imprensa Oficial do Estado, Arquivo do Estado, 1982).

MA - MOE, 204

MACHADO, Anísio

204. Anilse; conto (MAm)

[Araraquara, fev., nov. 1942 - 18 fev. 1943]

Datiloscrito original, fita azul; papel branco; 4 folhas; f. 1-2, 4: 32,4/32,5 x 22,3 cm, f. 3: $31,7 / 32,0 \times 22,2 / 22,3 \mathrm{~cm}$; borda direita cortada; f. 3: borda inferior recortada; $f$. 4: rasgamento nas bordas direita e inferior; vinco; escrita no anverso; f. 1: assinatura a máquina embaixo do título: "Conto de Aníbal Machado"; folhas numeradas pelo escritor em datiloscrito original fita vermelha: 2-4; rasuras a máquina, a tinta preta e a tinta azul; fólios numerados pela pesquisa: (1)-(4).

Notas MA a lápis vermelho: f. 1-2: grifos em trechos. 


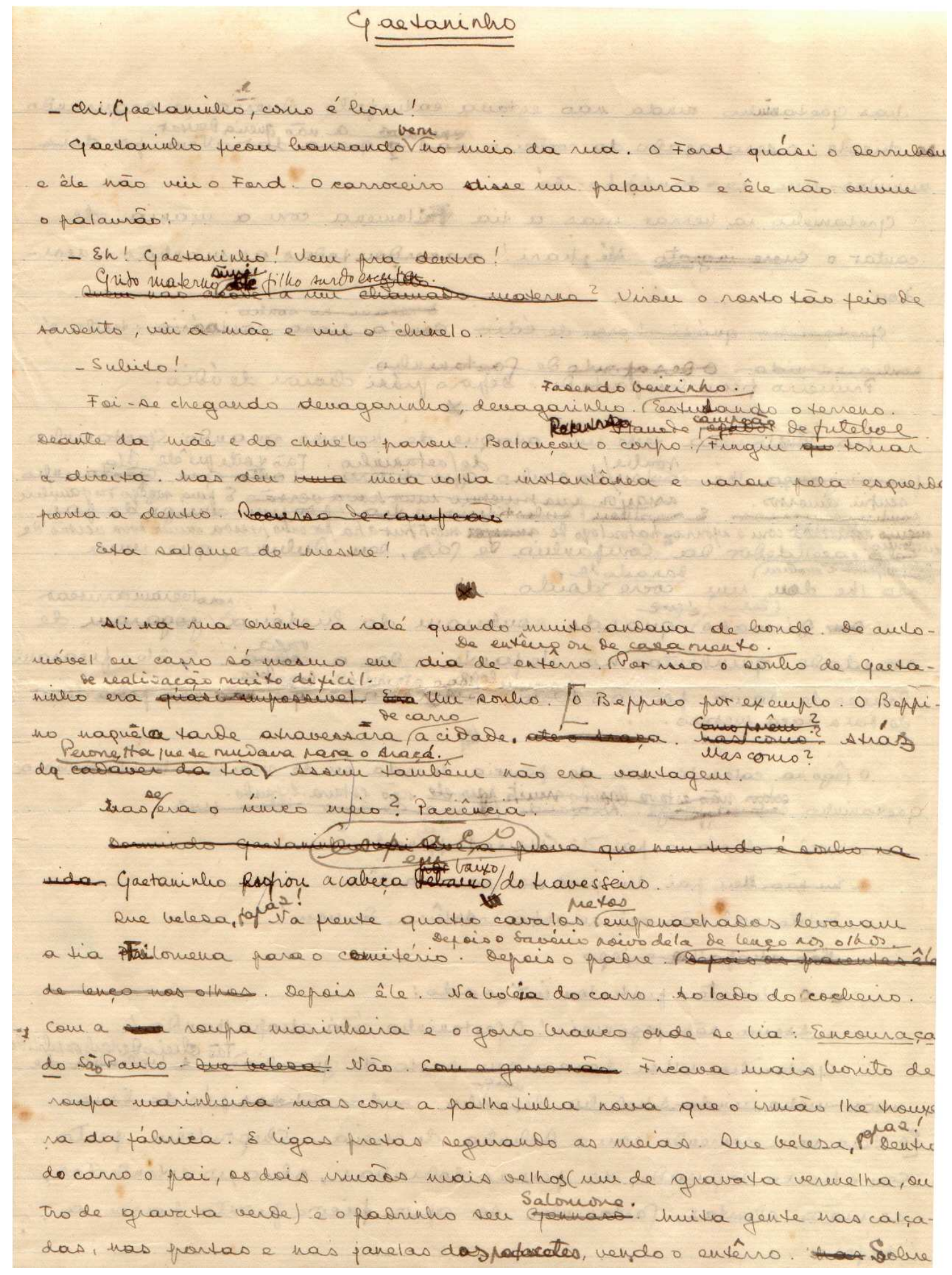




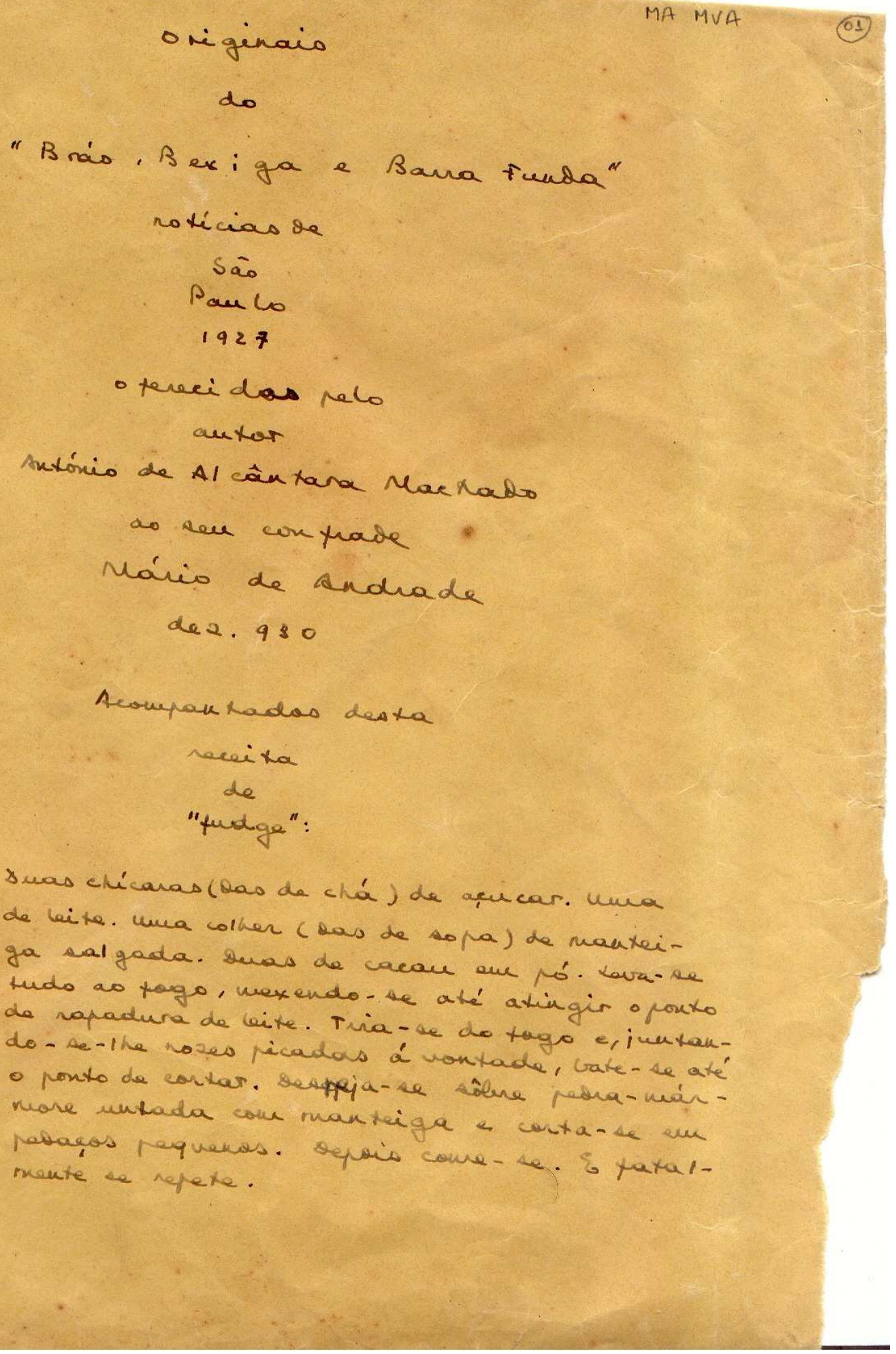


Notas da pesquisa:

1. Ms na vertente Mário de Andrade mentor.

2. Data e local atestados com base na carta a MA, de Araraquara, em 18 de fevereiro de 1943, onde o contista informa: "Junto envio uma crônica e dois contos. Antes que o sr. lance vis- | tas sôbre êles, dando-lhes uma rápida apreciação, [...] O conto 'O Poeta' foi escrito justamente há um ano; 'Analise', o ou- $\mid$ tro, em novembro último.[...] Acêrca desse conto algo me impele a dizer: Tudo | nele é real, sendo eu ou Rosendo, a fulana, minha companheira de serviço. | Sem colimar publicação, rascunhei aquela historieta para desabafar-me, | pois amava a tal cicrana e o único remédio para essa paixãozinha, foi mi- | nutar aquilo de um jacto. [...] Êsses dois trabalhinhos eu não os publiquei, por virtude, - como | reconheço! - de serem muito fracos." (Ref.: série Correspondência Mário de Andrade - sub-série Correspondência passiva; MA-C-CPL n 4359). Os três ms foram encaminhados a MA que os conservou em seu arquivo (V. MA-MOE, $205 \mathrm{e}$ MA-MOE, 206). O remetente indica na carta as datas de elaboração dos dois contos que foram passados a limpo em novembro de 1943, para serem remetidos a MA.

\section{Estudo genético:}

1. No arquivo MA o ms apresenta-se em uma única versão, A, passada a limpo no datiloscrito original que mostra 4 etapas prováveis na escritura: $a_{-} a_{1}, a_{2}, a_{3}$ :

a: datiloscrito completo;

$\mathrm{a}_{1}$ : rasuras a máquina;

$\mathrm{a}_{2}, \mathrm{a}_{3}$ : rasuras a tinta preta e azul.

\section{MA - MOE, 205}

\section{MACHADO, Anísio}

205. O poeta; conto (MAm)

[Araraquara, fev., nov. 1942 - 18 fev. 1943]

Datiloscrito, original fita azul; papel branco; 4 folhas; f. 1: 32,4/32,5 x 21,8/22,3 cm, f. 2-3: $32,4 / 32,5 \times 22,3 \mathrm{~cm}$, f. $4: 13,3 / 13,4 \times 22,2 \mathrm{~cm}$; borda direita cortada; f. 4 : borda inferior recortada; vinco; escrita no anverso; f. 1: autoria embaixo do título: "Conto de Anísio Machado"; folhas numeradas pelo escritor em datiloscrito original fita vermelha: 2-4; rasuras a máquina e a tinta preta; fólios numerados pela pesquisa: (1)-(4).

\section{Notas da pesquisa:}

1. Ms na vertente Mário de Andrade mentor.

2. Data e local atestados com base na carta a MA, de Araraquara, em 18 de fevereiro de 1943, onde o contista informa: "Junto envio uma crônica e dois contos. Antes que o sr. lance vis- | tas sôbre êles, dando-lhes uma rápida apreciação, [...] O conto 'O Poeta' foi escrito justamente há um ano; 'Analise', o ou- $\mid$ tro, em novembro último.[...] Acêrca desse conto algo me impele a dizer: Tudo | nele é real, sendo eu ou Rosendo, a fulana, minha companheira de serviço. | Sem colimar publicação, rascunhei aquela historieta para desabafar-me, | pois amava a tal cicrana e o único remédio para essa paixãozinha, foi mi- $\mid$ nutar aquilo de um jacto. [...] Êsses dois trabalhinhos eu não os publiquei, por 
virtude, - como | reconheço! - de serem muito fracos." (Ref.: série Correspondência Mário de Andrade - sub-série Correspondência passiva; MA-C-CPL, n 4359). Os três ms foram encaminhados a MA que os conservou em seu arquivo (V. MA-MOE, $204 \mathrm{e}$ MA-MOE, 206). O remetente indica na carta as datas de elaboração dos dois contos que foram passados a limpo em novembro de 1943, para serem remetidos a MA.

\section{Estudo genético:}

1. No arquivo MA o ms apresenta-se em uma única versão, A, passada a limpo no datiloscrito original que mostra 3 etapas prováveis na escritura: $a-a_{1}-a_{2}-a_{3}$ :

a: datiloscrito completo;

$\mathrm{a}_{1}$ : rasuras a máquina;

$\mathrm{a}_{2}$ : rasuras a tinta preta.

MA - MOE, 206

MACHADO, Anísio

206. Rodolfo G. Muricca; crônica (MAm)

Araraquara, 1 de fevereiro de 1943

Datiloscrito, cópia carbono preto; papel branco; 3 folhas; f. 1: 28,9/29,2 x 22,2 cm, f. 2: $28,7 / 29,0 \times 22,2 \mathrm{~cm}, \mathrm{f} .3: 28,0 / 29,0 \times 22,2 \mathrm{~cm}$; bordas superior e inferior recortadas; f. 3: rasgamento na borda inferior; vinco; manchas de carbono; escrita no anverso; f. 1: epígrafe: “"A verdade não enunciada torna-se | perigesa' venenosa' | Nietzsche" e assinatura a máquina: "Anísio Machado"; f. 3: local e data: "Araraquara, 1 de fevereiro de 1943.-"; rasuras a tinta preta e azul; fólios numerados pela pesquisa: (1)-(3).

Notas da pesquisa:

1. Ms na vertente Mário de Andrade mentor.

2. Data e local atestados com base na carta a MA, de Araraquara, em 18 de fevereiro de 1943, onde o contista/ cronista informa: "Junto envio uma crônica e dois contos. Antes que o sr. lance vis- | tas sôbre êles, dando-lhes uma rápida apreciação, [...] O conto ' $\mathrm{O}$ Poeta' foi escrito justamente há um ano; 'Analise', o ou- | tro, em novembro último.[...] Acêrca desse conto algo me impele a dizer: Tudo | nele é real, sendo eu ou Rosendo, a fulana, minha companheira de serviço. | Sem colimar publicação, rascunhei aquela historieta para desabafar-me, | pois amava a tal cicrana e o único remédio para essa paixãozinha, foi mi- $\mid$ nutar aquilo de um jacto. [...] Êsses dois trabalhinhos eu não os publiquei, por virtude, - como | reconheço! - de serem muito fracos." (Ref.: série Correspondência Mário de Andrade - sub-série Correspondência passiva; MA-C-CPL, $\mathrm{n}^{\circ}$ 4359). Os três ms foram encaminhados a MA que os conservou em seu arquivo (V. MA-MOE, 204 e MA-MOE 205). O remetente indica na carta as datas de elaboração dos dois contos que foram passados a limpo em novembro de 1943, para serem remetidos a MA. 
Estudo genético:

1. No arquivo MA o ms apresenta-se em uma única versão, A, passada a limpo no datiloscrito original que mostra 3 etapas prováveis na escritura: $a_{-} a_{1}, a_{2}, a_{3}$ :

a: datiloscrito completo;

$\mathrm{a}_{1}$ : rasuras a tinta preta;

$\mathrm{a}_{2}$ : rasuras a tinta azul.

MA - MOE, 207

MACHADO, Leão (Leão Machado de Sales 1904-1976)

207. Cidade de Itápolis; ensaio (MAm)

São Paulo, out. 1937

Datiloscrito original, fita preta; papel branco; 17 folhas; 32,2 x $22,0 \mathrm{~cm}$; f. 3 : pequenos rasgamentos na borda inferior à esquerda; vinco; sinais de fungo; f. 10: manchas de carbono; f. 17 no verso: ferrugem de clipe na borda superior à esquerda; escrita no anverso; f. 17: local, data e assinatura: "São Paulo, outubro de 1937 | Leão Machado"; folhas numeradas pelo escritor: 1-17; rasuras a máquina, a tinta preta e a lápis preto; fólios numerados pela pesquisa: (1)-(1) (7).

Anexos:

1) 16 fotografias da cidade de Itápolis; [post. 10 fev. 1938]; preto e branco; 7,4 x 11,2 $\mathrm{cm}$.

2) Envelope para acondicionamento das fotos: papel branco, timbrado em alto relevo: "SECRETARIA DA AGRICULTURA, INDUSTRIA E COMMERCIO | GABINETE DO SECRETARIO | S.PAULO"; interior do envelope forrado com papel de seda verde; sinais de fungo; mancha de carbono preto no canto inferior esquerdo; ferrugem de clipe na borda superior à esquerda; rasura a tinta preta: traços anulando o timbre; fólio numerado pela pesquisa: (1).

Nota MA a lápis preto: "Fotos Itapolis | pertence a Leão Machado".

3) Carta de MA a LM; datada: "São Paulo, 10 de fevereiro de 1938"; forma de tratamento: "Meu caro consorcio Leão Machado"; s/ assinatura; datiloscrito, cópia carbono preto; papel branco, timbrado: "SOCIEDADE DE ETNOGRAFIA E FOLCLORE | DEPARTAMENTO DE CULTURA | SÃO PAULO"; 1 folha; 28,0 x 22,0 cm; vinco; sinais de fungo; escrita no anverso; fólio numerado pela pesquisa: (1).

Notas da pesquisa:

1. Ms na vertente Mário de Andrade mentor.

2. O autor pertencia à Sociedade de Etnografia e Folclore do Departamento de Cultura de São Paulo, entidade fundada por MA e Dina Lévi-Strauss, conforme MA comenta na carta acima citada.

3. Fotografias com data atestada tomando como base a sugestão de MA na carta a Leão Machado, em 10 de fevereiro de 1938: "Estou desde muito pra lhe escrever sobre o trabalho que | está fazendo a respeito de Itapolis. Li-o com verdadeira delicia, ape- | nas tendo pena de que Itapolis fosse tão pouco... floclôrico. A ausência | de tradições é que enfraquece um bocado, não o valor, mas a importância | do trabalho. Mas êste é 
modelar e precisa continuar e completar-se | Acredite que não lhe estou fazendo nenhum elogio gratuito... pra animar | Considero realemente o trabalho já feito, excelente. Ajuntando-lhe do- | cumentação fotografica ficará ainda melhor."

\section{Estudo genético:}

1. No arquivo MA o ms apresenta-se em uma única versão, A, passada a limpo no datiloscrito que mostra 4 prováveis etapas na escritura: $a-a_{1}-a_{2}-a_{3}$ :

a: datiloscrito completo;

$\mathrm{a}_{1}$ : rasuras a máquina;

$\mathrm{a}_{2}$ : rasuras a tinta preta e a lápis preto.

a3: rasuras a lápis preto.

\section{MA-MOE, 208}

Maria da Glória; ROSSI, Italia; SPERA, Miguel; F.G., Ruth

208. Receita de um "Pai de Santo"; Auto-apresentação; "Fala a figa"; "Mau oiádo"; "Bom olhar"; poesia (MAc)

[São Paulo, 1935-1937?]

Datiloscrito original, fitas preta e vermelha; papel branco, filigrana; 7 folhas; $21,9 \mathrm{x}$ 15,4/15,7 cm, com variações em mm; irregularidades na borda esquerda; f. 1-2, 4-5: rasgamentos na borda esquerda; f. 3: rasgamento no canto inferior esquerdo e mancha de carbono roxo; f. 3-7: restos de cola e de papel; f. 6: rasgamentos no canto superior esquerdo e na borda direita, borda superior à esquerda recortada; escrita no anverso; f. 1-6: 2 furos de grampo; f. 7: 2 furos e ferrugem de grampo; vinco; sinais de fungo; f. 1-6: molduras nas bordas feitas a máquina; capa com as iniciais dos escritores em molduras com formato de losango feitas a máquina; f. 7: contra capa em branco; folhas numeradas a lápis preto: 1-5; rasuras a máquina; fólios numerados pela pesquisa: (1)-(7).

Receita de um "Pai de Santo":

Indicação de autoria no final do poema: "Por M.da G."; assinatura: "Maria da Gloria".

Auto-apresentação:

Pseudônimo no final do poema: "Ass. A Figa"; assinatura a máquina: "Por I.R.” e assinatura autógrafa: "Italia Rossi".

"Fala a figa":

Indicação de autoria no final do poema: "Por M.S.”; assinatura: "Miguel Spera".

"Mau oiádo":

Indicação de autoria no final do poema: "Por rf." e assinatura: "Ruth [?]".

"Bom olhar":

Indicação de autoria no final do poema: "Por F.G." e assinatura ilegível. 
Notas da pesquisa:

1. Ms na vertente Mário de Andrade colecionador.

2. MA conservou os poemas da brincadeira feita por companheiros seus do Departamento de Cultura da Municipalidade de São Paulo, no período em que dirigiu o Departamento.

3. Maria da Glória é provavelmente Maria da Glória Capote Valente.

Estudo genético:

1. No arquivo MA o ms apresenta-se em uma única versão, A, o datiloscrito original que mostra em "Mau oiádo" e "Bom olhar" 1 etapa na escritura, e, em Receita de um "Pai de Santo", Auto-apresentação e "Fala a figa", 2 etapas na escritura: a-a

a: datiloscrito completo;

$\mathrm{a}_{1}$ : rasuras a máquina.

MA - MOE, 209

MEDEIROS, Aluízio (Aluízio Caldas Medeiros 1918-1971)

209. Rondó sem fim; Acalanto da vigília; Saudosismo; Mãos; Ronda da mulher sozinha; poesia (MAm)

[Fortaleza, ant. 18 fev. 1944]

Datiloscrito, cópia carbono azul; papel branco; 4 folhas; 27,6 x 18,5/18,6 cm; vincos; sinais de fungo; escrita no anverso; f. 4: assinatura a máquina: "Aluízio Medeiros"; folhas numeradas pelo escritor: 2-4; rasuras a máquina; fólios numerados pela pesquisa: (1)-(4).

Acalanto da vigília:

Nota MA a lápis preto: comentário e sugestão de substituição.

Mãos:

Nota MA a lápis preto: sugestão de substituição.

Ronda da mulher sozinha:

Nota MA a lápis preto: sugestão de substituição.

Notas da pesquisa:

1. Ms na vertente Mário de Andrade mentor.

2. Local e data atestados com base na carta a MA, de Fortaleza, 18 de fevereiro de 1944, junto da qual o poeta envia os textos: "[...] recebí o seu cartão de agradecimento ao | meu telegrama de bôas festas e feliz ano novo. Nele v. me per- | gunta o que ando fazendo, tambem. Continuo, com grandes inter- | valos, fazendo poemas, e deles mando uma amostra pra v. Julgo | que venho me libertando das imperfeições que v. me apontou quan- | do publiquei o "Trágico Amanhecer". V. , entretanto, me dará a | sua opinião, espero. [...]" (Ref. cruzada: série Correspondência Mário de Andrade - subsérie Correspondência passiva; MA-C-CPL, nº 4587). 
3. Na missiva do escritor cearense a MA, de Fortaleza, 2 de julho de 1944, estão agradecimentos aos comentários recebidos de MA (Ref. cruzada: série Correspondência Mário de Andrade - sub-série Correspondência passiva; MA-C-CPL, $n^{\circ} 4588$ ).

4. Os poemas no ms entraram no livro de Aluízio Medeiros, Mundo evanescente (Ceará, Editora Fortaleza, 1944).

Estudo genético:

1. No arquivo MA o ms apresenta-se em uma única versão, A, na cópia do datiloscrito que mostra, em Saudosismo, 1 etapa na escritura, e, nos demais poemas, 2 etapas: a- $a_{1}$ :

a: datiloscrito completo;

$\mathrm{a}_{1}$ : rasuras a máquina.

2. A versão A foi confrontada com a versão B, em Mundo evanescente (ed. cit.). Com exceção de Rondó sem fim, os textos dos poemas apresentam variantes.

3. A versão B de Mãos incorporou a sugestão da Nota MA aposta ao ms.

MA - MOE, 210

MEIRELES, Cecília (Cecília Meireles Grilo 1901-1946)

210. Três motivos da rosa: 1. "Vejo-te em sêda e nácar"; 2. "Por mais que te celebre, não me escutas"; 3. "Si Omar chegasse"; poesia (MAc)

[Rio de Janeiro, ant. 15 mar. 1943]

Datiloscrito original, fita preta; papel branco, filigrana; 1 folha; 31,9 x $21,9 \mathrm{~cm}$; pequenos rasgamentos nas bordas esquerda, direita e inferior; vincos com 2 rasgamentos; sinais de fungo; escrita no anverso; assinatura a tinta preta: "Cecília Meireles"; poemas numerados: 1-3; rasuras a máquina e a tinta preta; fólio numerado pela pesquisa: (1).

Notas da pesquisa:

1. Ms na vertente Mário de Andrade colecionador.

2. Local e data atestados com base na carta a MA, do [Rio de Janeiro], 15 de março de 1943, junto da qual CM envia o ms: "lembrei-me de lhe mandar | 'tres motivos da rosa', que devem sair no meu pró- | ximo livro. Justamente, eu queria dedicar a você | um poeminha: lembrança da contemporaneidade lírica | E as rosas veem a propósito, embora seja um caso | bem único o de uma mulher oferecer uma rosa a um | homem... Acho que é único, mas minha instrução no | assunto tem lacunas consideráveis. Entretanto, | é rosa e não é rosa: pois que é apenas poema da | rosa. | Ora, como são tres, voilà, Mr., l'embarras du | choix. Então, pensei: copio todos, e mando. Você | vê qual é o menos pior, e me diz: êste fica sendo $\mid$ meu. Eu lhe digo à moda de hoje: O. K. E pronto. Tão | simples, a vida! | [...] mande dizer qual é | a sua rosa, para eu escrever seu nome no lugar". (Ref. cruzada: série Correspondência Mário de Andrade - sub-série Correspondência passiva; MA-C-CPL, $\mathrm{n}^{\circ}$ 4616)

3. Os poemas foram publicados em Mar absoluto e outros poemas (Porto Alegre, Livraria O Globo, 1945), na mesma seqüência, com o título geral "Três motivos da rosa".

4. No livro, publicado depois da morte de MA, em 25 de fevereiro de 1945, o "20 motivo da rosa" está dedicado a ele. 
Estudo genético:

1. No arquivo MA o ms apresenta-se em uma única versão, A, passada a limpo no datiloscrito original que mostra 3 etapas na escritura: $a-a_{1}, a_{2}$ :

a: datiloscrito completo;

$\mathrm{a}_{1}$ : rasuras a máquina;

$\mathrm{a}_{2}$ : rasuras a tinta preta.

2. A versão A confrontada com a versão publicada, B, em Mar absoluto e outros poemas. (ed. cit.), exibe variantes. Na versão B "Vejo-te em sêda e nácar" ganhou o título "10 motivo da rosa", "Por mais que te celebre, não me escutas" teve como título " 2 " motivo da rosa", e "Si Omar chegasse", o título "30 motivo da rosa".

\section{MA - MOE, 211}

MENDES, Murilo (Murilo Monteiro Mendes 1901-1975)

211. Acontecimento; Anjo diplomata; A menina do Otel; Anunciação.; Anjos maus; A recompensa; Aritmetica; A sésta; Biografia do muzico; Canção do ezilio; Cartão postal; Cartaz do Brazil e da Russia; Céo; Cordão; Escola de Belas-artes; Endereço das cinco Marias; Froide; Evolução; Gravitação; Idilio; Itinerario; Jornal.; Juiz de fóra; Manifestação; Marcha; Prezagios; Noticia; Noturno do Brazil e da Russia; Noturno rezumido; Omem; Omem acordado; Omem e anjo; $O$ omem e a noite; Omem e movimento perpetuo; Omem morto; Omem olhando pro ceó; Omem trabahando; $O$ menino sem passado; Paizagem; Prezença; Retrato; Russia; Sala de jantar; São Francisco de Assis; Uma noite no Distrito Federal; Viagem; Vocação; Xodó; poesia (MAd)

Rio de Janeiro, [ant. 1930]

Datiloscrito, cópia carbono roxo: f. 1-53; datiloscrito original, fita preta: f. 14; papel branco, filigrana; 53 folhas; $28 \times 21 \mathrm{~cm}$, com variações em mm; f. 14: margem superior amassada com rasgamento; f. 16, 28, 36, 39, 46-49: canto superior esquerdo amassado; f. 36: rasgamento na borda superior; f. 38: cantos superior e inferior esquerdo rasgados; f. 39: rasgamento no canto superior esquerdo; f. 40: margem esquerda amassada; f. 41: 2 rasgamentos na margem direita; f. 44: rasgamentos na margem esquerda; f. 50: rasgamentos nas margens direita e esquerda; vincos: 1-3, 10, 21, 50; sinais de fungo; manchas de carbono; escrita no anverso; f. 9: assinatura e local: "Murillo Monteiro Mendes | Rio"; rasuras a máquina e a lápis preto; fólios numerados pela pesquisa: (1)-(5) (3)

\section{Anexo:}

Recorte de jornal: fragmento sem título de texto de Tristão de Athayde na coluna "Vida literária", do Diário de Notícias do Rio de Janeiro, com do poeta a lápis preto: "14-IV-29"; texto: "Ha pouco mais de um mez recebi um rolo de poemas dactylographados, e seguidos da seguinte carta: - 'Junto encontrará v. varios poemas escriptos pelo meu amigo Murillo Monteiro Mendes. Acho que a divulgação delles constituiria um verdadeiro daso literario, pois não conheço nenhum poeta moderno de tão diversos aspectos como elle. Faltam-me nome e autoridade publica para escrever 


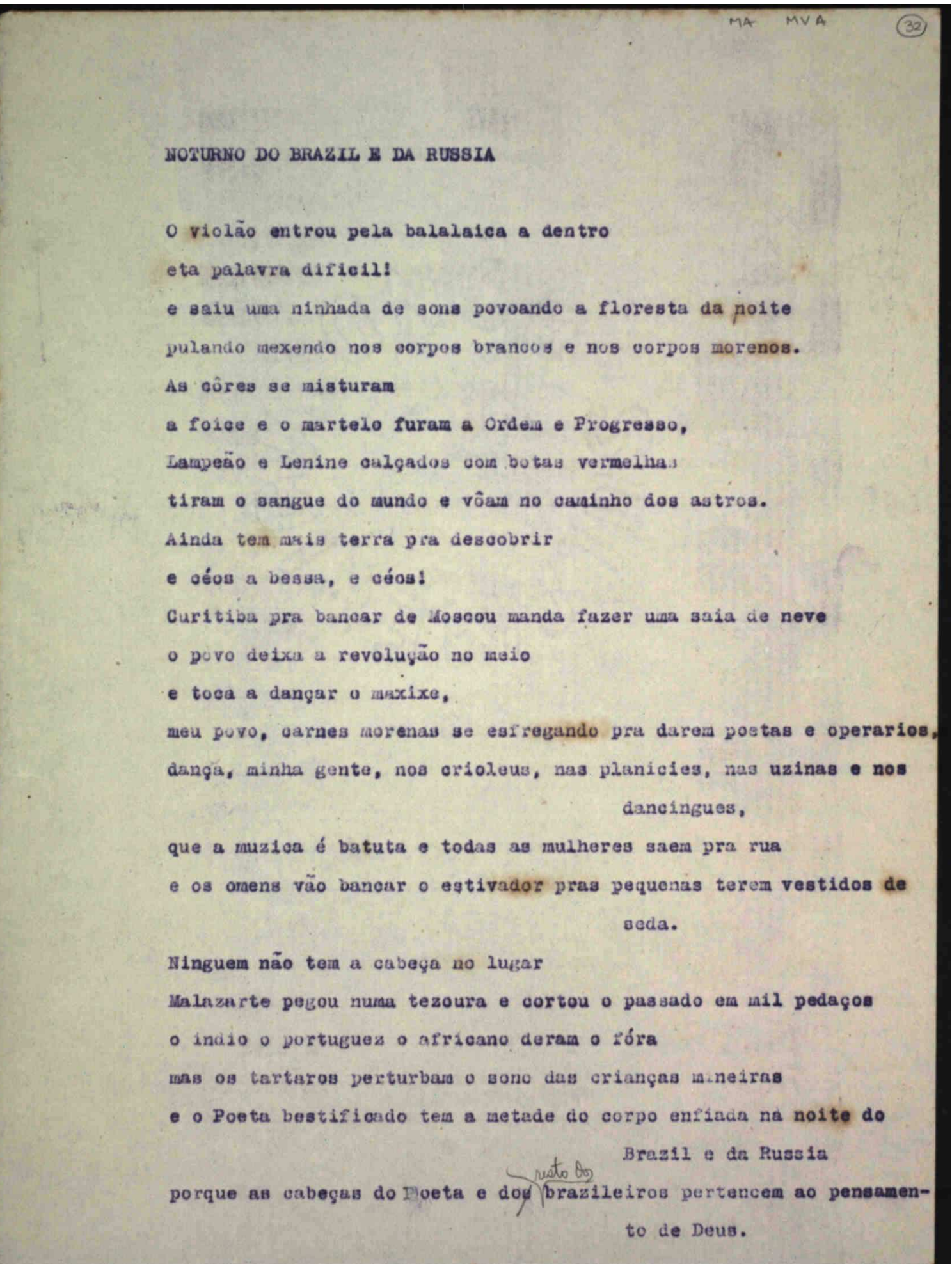




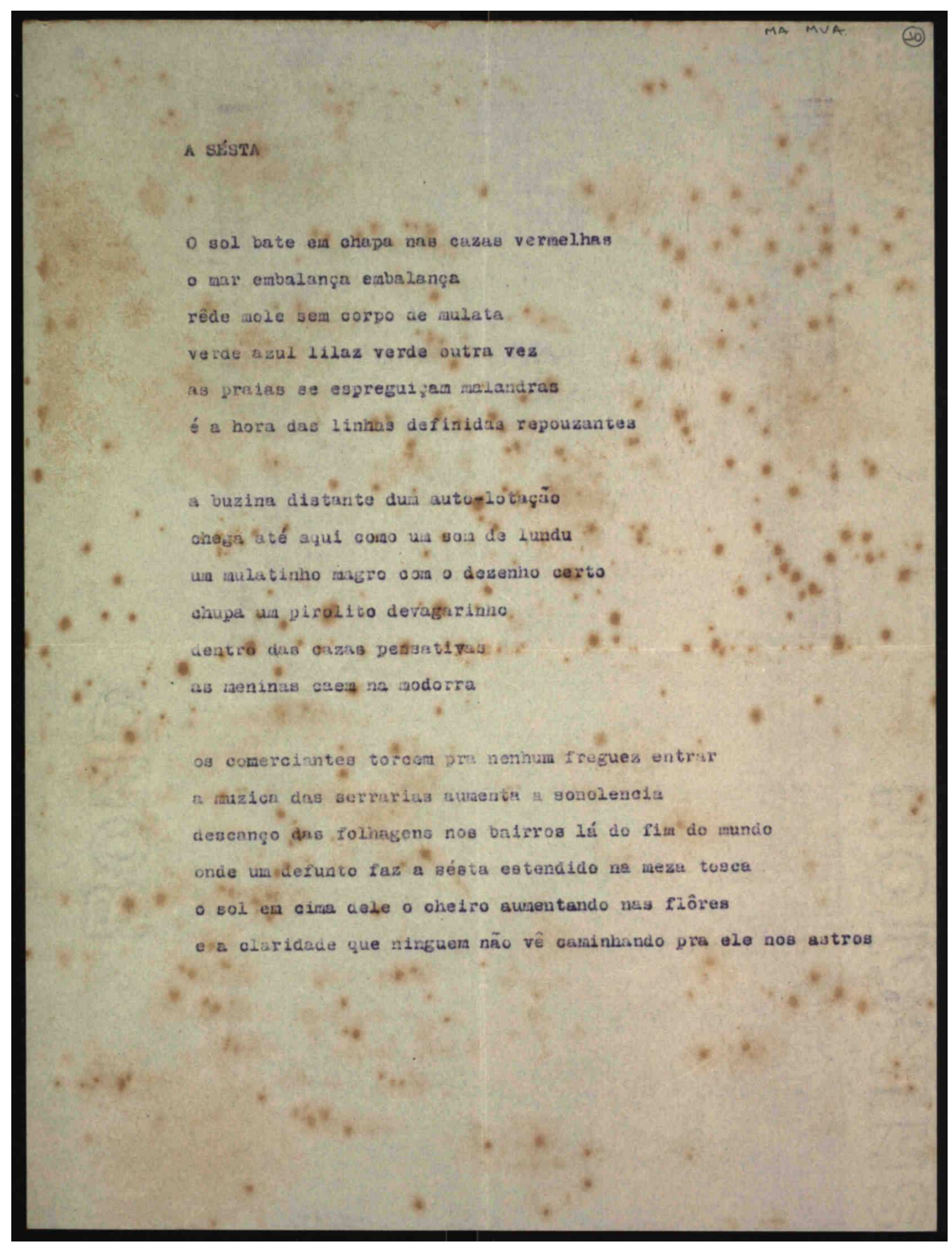


sobre tão singular artista, do contrario já o teria feito. Não me dou por conhecer por motivos que não vêm ao caso" Citados Republica e Exame de consciencia.

Notas da pesquisa:

1. Ms na vertente Mário de Andrade no diálogo interpares.

2. Anjos maus, A sésta, Biografia do muzico, Canção do ezilio, Cartão postal, Endereço das cinco Marias, Noturno do Brazil e da Russia, Noturno rezumido, Omem morto, Omem trabahando, O menino sem passado, Sala de jantar, Uma noite no Distrito Federal e Vocação foram publicados em Poemas (Juiz de Fora, Dias Cardoso, 1930).

3. MA conservou um exemplar do livro em sua biblioteca com a dedicatória: "Ao Mario de Andrade | com um abraço do | Murilo Mendes | Juiz de Fora, 1930. Caixa Postal 33".

4 Hipótese de data com base no ano de publicação de Poemas, 1930 (ed. cit.).

Estudo genético:

1. No arquivo MA os poemas apresentam-se em uma única versão, A, a cópia carbono do datiloscrito.

2. O ms mostra 3 estapas na escritura: $a-a_{1}$ :

a: datiloscrito completo;

$\mathrm{a}_{1}$ : rasuras a máquina;

$\mathrm{a}_{2}$ : rasuras a lápis preto.

MA - MOE, 212

MENDES, Murilo (Murilo Monteiro Mendes 1901-1975)

212. Anjo quimico; Marinha; Poema sem saída; Reza; Xodó $n^{o} 2$; poesia (MAd)

[Rio de Janeiro, ant. 1930]

Datiloscrito, cópia carbono preto; papel branco, filigrana; 7 folhas; 27,9 x $21 \mathrm{~cm}$, com variações em mm; vincos; sinais de fungo; manchas de tinta de carbono roxo; f. 5: margem superior à esquerda amassada com rasgamento e rasgamentos na borda inferior; f. 6: rasgamentos na borda superior e manchas de carbono; escrita: no anverso: f. 1-7, no verso: f. 3 e verso; rasuras a máquina, a lápis, a tinta preta e a tinta azul; fólios numerados pela pesquisa: (1)-(7).

Anjo quimico:

Nota MuM: "fazer outro".

Notas da pesquisa:

1. Ms na vertente Mário de Andrade no diálogo interpares.

2. Marinha foi publicado nos livros Poemas (Juiz de Fora, Dias Cardoso, 1930) e Os quatro elementos (Porto Alegre, Globo, 1945). 
Estudo genético:

1. No arquivo MA o ms apresenta-se em uma única versão, A, cópia no datiloscrito que, em Xodó $n^{o}$ 2, mostra 2 etapas na escritura: a-a ${ }_{1}$, e em Anjo quimico, Marinha e Reza 3 etapas na escritura: $\mathrm{a}-\mathrm{a}_{1}-\mathrm{a}_{2}$ :

a: datiloscrito completo;

$\mathrm{a}_{1}$ : rasuras a máquina; $\mathrm{a}_{2}$ : rasuras a lápis.

2. Poema sem saida mostra diferentes etapas na escritura a serem tratadas de forma detida em trabalho específico.

\section{MA - MOE, 213}

MENDES, Murilo (Murilo Monteiro Mendes 1901-1975)

213. Diurno de Belorizonte; poesia (MAd)

[Belo Horizonte], 27 nov. 1930

Autógrafo a tinta preta; papel branco, pautado, timbrado: "GABINETE DO PRESIDENTE | DO ESTADO DE MINAS | Bello Horizonte", anulado por traço diagonal a tinta preta; 1 folha; 21,5 x 12,1 cm; vinco; sinais de fungo; escrita no anverso; data: "27.XI.30"; fólio numerado pela pesquisa: (1).

Nota MA a lápis preto: "Murilo Mendes".

Nota da pesquisa:

1. Ms na vertente Mário de Andrade no diálogo interpares.

\section{Estudo genético:}

1. No arquivo MA o ms apresenta-se em uma única versão, A, passada a limpo no autógrafo que mostra 1 etapa na escritura.

MA - MOE, 214

MENDES, Murilo (Murilo Monteiro Mendes 1901-1975)

214. Juizo final dos olhos; Diurno do alucinado; poesia (MAd)

[Rio de Janeiro], 1930

Datiloscrito original, fita preta: o poema Juizo final dos olhos; autógrafo a lápis preto: o poema Diurno do alucinado; papel branco, filigrana; os dois poemas estão em 1 única folha; 20,5 x 22,0 cm; pequenos rasgamentos nas bordas esquerda, direita e inferior; vincos; sinais de fungo; escrita no anverso; rasuras a máquina e a lápis preto; fólio numerado pela pesquisa: (1).

Notas MuM a lápis preto: no final de Juizo final dos olhos: "Poemas sem espaço' | (1930)"; no final de Diurno do alucinado: “('Poemas de quebra') | 1930".

Nota MA a lápis preto na margem inferior à esquerda: "Murilo Mendes". 
Nota da pesquisa:

1. Ms na vertente Mário de Andrade no diálogo interpares.

Estudo genético:

1. No arquivo MA Juizo final dos olhos apresenta-se em uma única versão, A, passada a limpo no datiloscrito original que mostra 3 etapas na escritura: $a-a_{1}-a_{2}$ :

a: datiloscrito completo;

$\mathrm{a}_{1}$ : rasura a máquina;

$\mathrm{a}_{2}$ : rasuras a lápis preto.

2. Diurno do alucinado apresenta-se em uma única versão, A, o datiloscrito na cópia que mostra 1 etapa na escritura.

MA - MOE, 215

MENDES, Murilo (Murilo Monteiro Mendes 1901-1975)

215. Jandira; poesia (MAd)

[Rio de Janeiro, ant. 28 maio 1932]

Autógrafo a tinta preta; papel branco, pautado; 4 folhas; 23,5/ 23,7 x 15,8/ $16 \mathrm{~cm}$, com variações em mm; borda esquerda irregular; vincos; f. 1, 3-4: sinais de fungo; $\mathrm{f}$. 1: mancha de tinta azul; escrita no anverso; folhas numeradas pelo escritor: $2-4$; f. 1 : assinatura: "Murilo Mendes"; fólios numerados pela pesquisa: (1)-(4).

Notas da pesquisa:

1. Ms na vertente Mário de Andrade no diálogo interpares.

2. Data atestada com base na carta a MA, do Rio de Janeiro, 28 de maio de 1932, junto da qual o poeta enviou cópia de Jandira. Trata-se de segunda cópia do poema, pois, missiva do Rio de Janeiro, 3 de março de 1932, Murilo estranha a ausência de comentários ao poema Jandira, remetido em janeiro do mesmo ano, em carta que provavelmente se extraviou (Ref.: série Correspondência Mário de Andrade - sub-série Correspondência passiva; MA-C-CPL, $n^{\circ} 4660$ e MA-C-CPL, no 4661).

3. Jandira foi publicado em $O$ visionário (Rio de Janeiro, José Olympio, 1941).

Estudo genético:

1. No arquivo MA o ms apresenta-se em uma única versão, A, passada a limpo no autógrafo que mostra 1 etapa na escritura.

MA - MOE, 216

MENDES, Murilo (Murilo Monteiro Mendes 1901-1975)

216. $O$ sinal de Deus; poesia (MAd)

[Rio de Janeiro], jan./fev. 1936

Autógrafo a tinta azul; caderno tipo brochura; capa cor de laranja; 23,2 x 16,4 cm; ferrugem de clipe no verso; quarta-capa: manchas; perfurações por insetos; miolo: 
papel branco, pautado; 67 folhas; $23,2 \times 16,4 \mathrm{~cm}$; sinais de fungo; f. 1-3: coladas pela margem esquerda; sinal de que a primeira folha do caderno foi recortada; f. 2: ferrugens de clipe; f. 3, 65: recortadas com tesoura; f. 4: restos de cola; f. 49: tinta borrada, manchando o verso da folha anterior; f. 66-67: estão nelas coladas folha de caderno pautada, filigrana, 24,9/25,6 x 21,0 cm, dobradas nas margens direita e inferior; f. 60-64, 66-68: perfurações por inseto; escrita no anverso; f. 67: marcas de folha descolada, deixando vestígio de texto; f. 69-72: arrancadas, sobrando pedaços da margem esquerda com texto; escrita no anverso; rasuras a lápis preto, a tinta azul, a tinta preta; fólios numerados pela pesquisa: (1)-(7) (0). Notas MuM: f. 1: a lápis preto: "Este livro foi escrito em 1936 | (janeiro-fevereiro)"; f. 3: "Copiar os poemas como | estão aqui. Como se | fôsse prosa"; a tinta preta na capa: "Murilo Mendes | 20-3-36"; a tinta azul na quarta-capa: símbolo católico.

Nota MA a lápis preto: f. 14: sugestão de substituição: “milhor tirar 'a seu respeito' | $\left(\mathrm{m}^{\mathrm{to}}\right.$ feio $)$ ".

O ms apresenta os títulos: O homem e a mulher; Carmen; Dulce; Madalena; Stella; Ruth; Eleonora; Clara; Par impar; Lucilia; $O$ amigo do esposo; Matilde; A desconsoladora; Regina; A dama do mar; Esposos; Marta; Violeta; Celia; Vanda; Uma e unica; A irmã de pedra; Juizo final do amor; $O$ amor eterno; Miriam; Mulheres solteiras; $O$ antigo namorado; A mãi assassina; $O$ poeta, a musa e a noite; Vigilia; A tempestade; $O$ ditador; Aurora; $O$ poeta; $O$ novo céu e a nova terra; Solidão do homem sem Cristo; Enterro; Nossa vida; Consciência; Genealogia; O dia e a noite; Depois de mim; $O$ estranjeiro da vida; $O$ homem antigo e o homem novo; $A ́$ virgem Maria; A segunda vinda; Universal; Ação; Alpha e Omega; A musa das musas.

Anexo:

Envelope azul claro, estampado; 63,0 x 66,4 cm; dobrado em várias partes; sinais de fungo; rasgamentos; fólio numerado pela pesquisa: (1). Nota MuM a tinta azul: "Mario de Andrade | P.E.F. | Mario: | Peço não mostrar. | M.".

Nota MA a lápis preto: "Murilo Mendes".

Notas da pesquisa:

1. Ms na vertente Mário de Andrade no diálogo interpares.

2. O O sinal de Deus saiu em 1936 pela editora carioca José Olympio e foi imediatamente recolhido por intervenção de Adalgisa Nery, ex-musa de MuM, que ia se casar Lourival Fontes, ligado ao governo de Getúlio Vargas.

\section{Estudo genético:}

1. No arquivo MA o ms apresenta-se em uma única versão, A, que mostra 4 prováveis etapas na escritura: $a-a_{1}-a_{2}-a_{3}$ :

a: autógrafo completo;

$\mathrm{a}_{1}$ : rasuras a tinta azul;

$\mathrm{a}_{2}$ : rasuras a tinta preta e a lápis preto. 
MA - MOE, 217

MENDES, Murilo (Murilo Monteiro Mendes 1901-1975)

217. Menina em quatro idades; Gilda; A mulher do dezerto; Madalena; Escapamento de gaz; poesia (MAd)

[Rio de Janeiro, ant. 1941?]

Datiloscrito, cópia carbono azul; papel branco; 5 folhas; 21,0/ 21,1 x 13,7 cm, com variações em mm; f. 1: furo; vincos; sinais de fungos; manchas do carbono; escrita no anveso; rasuras a máquina e a lápis preto; fólios numerados pela pesquisa: (1)-(5).

Notas da pesquisa:

1. Hipótese de local e data com base na edição de $O$ visionário (Rio de Janeiro, José Olympio, 1941).

2. Ms na vertente Mário de Andrade no diálogo interpares.

3. Menina em quatro idades e $A$ mulher do dezerto foram publicados em $O$ visionário.

\section{Estudo genético:}

1. No arquivo MA o ms apresenta-se em uma única versão, A, cópia no datiloscrito que mostra em Menina em quatro idades e Madalena 1 etapa na escritura, e em

Escapamento de gaz Gilda, A mulher do dezerto e Escapamento de gaz 2 etapas na escritura: a-a 1 :

a: datiloscrito completo;

$\mathrm{a}_{1}$ : rasuras a máquina.

\section{MA - MOE, 218}

MEYER, Augusto (Augusto Meyer Júnior 1902-1970)

218. Samba; Puladinho; poesia (MAm)

[Porto Alegre, ant. 14 out. 1928]

Datiloscrito original, fita vermelha; autógrafo a lápis tinta: f. 1: título Samba; autógrafo a lápis verde: f. 2: título e primeira letra do poema Puladinho; papel branco, pautado, filigrana; f. $1: 27,1 / 27,3$ x $19,6 / 19,8 \mathrm{~cm}$, f. $2: 23,8 / 24,2 \times 18,0 \mathrm{~cm}$; f. 1 : bordas direita e inferior cortadas; f. 2: bordas cortadas; vincos; sinais de fungo; escrita no anverso; rasuras a máquina e a tinta preta; fólio numerado pela pesquisa: (1).

\section{Anexo:}

Envelope branco, interior em papel azul estampado; 12,4 x 15,5 cm; sinais de fungo. Nota MA a lápis preto: “Augusto Meyer".

Notas da pesquisa:

1. Ms na vertente Mário de Andrade mentor.

2. Data e local atestados pela carta de AuM a MA, de Porto Alegre, posterior a 14 outubro 1928, onde se lê: "Mario, estou preparando os meus | Poemas de Bilú, especie de repertorio $\mid$ de irreverencias poeticas, tudo impregnado | de 'popularescos', pelo menos 
como | expressão, será coisa nova e viva (es-| péro). Mando amostra”. (Ref.: série Correspondência Mário de Andrade - sub-série Correspondência passiva; MA-C-CPL, $\left.\mathrm{n}^{\circ} 4731\right)$

3. Em carta de Porto Alegre, 29 abr. 1927, o poeta encaminhou poemas a MA: "Mando também alguns | poemas novos. Brincadeiras.". Não há como comprovar que sejam os mesmos poemas do ms da série MOE. (Ref.: série Correspondência Mário de Andrade sub-série Correspondência passiva; MA-C-CPL, $\mathrm{n}^{\circ}$ 4727)

4. Puladinho saiu em Poemas de Bilu (Rio de Janeiro, Pongetti, 1955).

Estudo genético:

1. No arquivo MS o ms apresenta-se em uma única versão, $\mathrm{A}$, passada a limpo no datiloscrito original.

2. Samba mostra 3 prováveis etapas na escritura: $a-a_{1}-a_{2}$ :

a-a : $_{1}$ datiloscrito completo e autógrafo a lápis;

$\mathrm{a}_{2}$ : rasuras a máquina

3. Puladinho mostra 3 etapas prováveis na escritura: $\mathrm{a}-\mathrm{a}_{1}-\mathrm{a}_{2}$ :

a- $a_{1}$ : datiloscrito completo e autógrafo a lápis;

$\mathrm{a}_{2}$ : rasuras a tinta preta.

4. A versão A de Puladinho, confrontada com a versão B, em Poemas de Bilu (ed. cit.), apresenta poucas variantes.

MA - MOE, 219

MILANO, Dante (1899-1991)

219. Saudades da minha vida; poesia (MAc)

[São Paulo, pos. 15 abr. 1926]

Apógrafo MA a tinta preta; papel branco; 15,5 x 10,5 cm; vinco; sinais de fungo; escrita no anverso e no verso; fólio numerado pela pesquisa: (1).

Notas MA no verso: "Dante Milano | (Comunicado por Manuel Bandeira)".

Notas da pesquisa:

1. Ms na vertente Mário de Andrade colecionador.

2. No corpo da carta a MA, do Rio de Janeiro, 15 de abril de [1926], Manuel Bandeira transcreveu o poema de DM, Saudades da minha vida e contou: "[...] de tarde fui me encontrar com o Dante pra irmos jantar com o Villa [...]. Lá o Dante puxa um papelzinho do bolso como menino que vai mostrar ao outro uma bolinha de gude e lê esta coisa incrível de simplicidade (em nossa poesia só o 'Minha terra tem palmeiras' pode encostar de longe)" (Correspondência Mário de Andrade \& Manuel Bandeira. Ed. cit., p. 285).

2. Data e local atestados com base na missiva de MB, pois após recebê-la, MA copiou o poema. De São Paulo, em 18 de abril de 1926, MA respondeu a Bandeira: "Vivi o seu dia feliz. O poema do Dante é de Dante, um colosso. Parece mesmo certos passos da Vida nova que fossem traduzidos pro ritmo mais brasileiro, impetuoso dentro de muito 
carinho. É realmente ũa maravilha" (Correspondência Mário de Andrade \& Manuel Bandeira. Ed. cit., p. 286).

4. Saudades da minha vida foi publicado em Poesia (Rio de Janeiro, José Olímpio, 1948).

Estudo genético:

1. No arquivo MA o ms apresenta-se em uma única versão, A, o apógrafo, cópia MA que mostra 1 etapa na escritura.

2. A versão A, confrontada com a versão B em Poesia (ed. cit.), mostra variantes.

MA - MOE, 220

MILANO, Dante (1899-1991)

220. Cordão; poesia (MAc)

[Rio de Janeiro, ant. $1^{\circ}$ maio] 1926

Datiloscrito, cópia carbono azul; papel branco; 32,5 x 21,9/22,0 cm; pequenos rasgamentos nas bordas; vincos; sinais de fungo; manchas de carbono; escrita no anverso; autoria e data: "DANTE MILANO | 1926”; fólio numerado pela pesquisa: (1).

Anexo:

Envelope branco; interior forrado com papel azul estampado; 12,4 x 15,5 cm; sinais de fungo; fólio numerado pela pesquisa: (4).

Nota MA a lápis preto: "Dante Milano".

Notas da pesquisa:

1. Ms na vertente Mário de Andrade colecionador.

2. Na carta de Manuel Bandeira a MA, do Rio de Janeiro, $1^{\circ}$ de maio de [1926], pode-se encontrar a data do envio de Cordão. O ms acompanhava cópia de música composta por Vila Lobos para o poema de Bandeira "O Anjo da Guarda", na carta que conta ter o compositor musicado também um poema de Dante Milano: "Com esta lhe mando sob registro uma cópia da música que o Villa escreveu prao 'Anjo da Guarda'. [...] O Villa musicou também a poesia do Dante. [...] Pra você conhecê-lo melhor, mando-lhe o 'Cordão' (devolva-me, não tenho cópia)" (Correspondência Mário de Andrade \& Manuel Bandeira. Ed. cit., p. 288). MA não devolveu o ms e providenciou um envelope para acondicioná-lo.

Estudo genético:

1. No arquivo MA o ms apresenta-se em uma única versão, A, passada a limpo na cópia que mostra 1 etapa na escritura. 
MA - MOE, 221

MILANO, Dante (1899-1991)

221. Pequena historia de amor; poesia (MAc)

[Rio de Janeiro] 1926

Datiloscrito original, fita preta; papel branco; 32,7/32,8 x 22,0/22,2 cm; irregularidades na borda esquerda; mancha de carbono roxo margem esquerda; vincos; sinais de fungo; escrita no anverso; autoria e data: "DANTE MILANO | 1926"; fólio numerado pela pesquisa: (2).

Notas da pesquisa:

1. Ms na vertente Mário de Andrade colecionador.

2. Em carta a MA, do Rio de Janeiro, em 21 de agosto de 1926, DM relembra encontro com ele naquele mesmo ano; é possível que o ms lhe tenha sido entregue nesse momento. (Ref. cruzada: série Correspondência Mário de Andrade - sub-série Correspondência passiva; MA-C-CPL, $\mathrm{n}^{\circ}$ 4868)

Estudo genético:

1. No arquivo MA o ms apresenta-se em uma única versão, A, passada a limpo no datiloscrito original que mostra 1 etapa na escritura.

MA - MOE, 222

MILANO, Dante (1899-1991)

222. Farra; poesia (MAc)

[Rio de Janeiro, 1926?]

Datiloscrito, cópia carbono azul; papel tipo jornal, beje; 27,6 x 20,7 cm; vincos; sinais de fungo; escrita no anverso; autoria: "DANTE MILANO"; fólio numerado pela pesquisa: (1).

Notas da pesquisa:

1. Ms na vertente Mário de Andrade colecionador.

2. Em carta a MA, do Rio de Janeiro, em 21 de agosto de 1926, DM relembra encontro com ele naquele mesmo ano; é possível que o ms lhe tenha sido entregue nesse momento. (Ref. cruzada: série Correspondência Mário de Andrade - sub-série Correspondência passiva; MA-C-CPL, $\mathrm{n}^{\circ}$ 4868)

\section{Estudo genético:}

1. No arquivo MA o ms apresenta-se em uma única versão, A, passada a limpo no datiloscrito original que mostra 1 etapa na escritura. 
MA - MOE, 223

MILLIET, Sérgio (Sérgio Milliet da Costa e Silva 1898-1966)

223. Foot-ball; conto (MAd)

[Paris, mar.-maio, 1923 ?]

Autógrafo a tinta preta; papel branco, irregularidades nas bordas direita, esquerda e inferior; 5 folhas; 27,0 x 21,0 cm; f. 1-3: canto superior direito rasgado; vincos; sinais de fungo; escrita no anverso; folhas numeradas pelo escritor: 2-5; f. 5 : assinatura a tinta preta: "Sergio Milliet"; f. 1: bilhete em autógrafo a tinta preta nas margens esquerda e superior rasuras a tinta preta; fólios numerados pela pesquisa: (1)-(5). Conteúdo do bilhete: "Te voici maître de portugais. L'eléve vagabond t'envoie | des compositions peus ou moins interessantes, muins | que plus!; margem superior: "Vai um conto escripto por troça e seu assumpto 'au courant | de la plume' para exercicio. Verás a mistura das | orthographias! - Łe Abraços Sergio".

Notas da pesquisa:

1. Ms na vertente Mário de Andrade no diálogo interpares.

2. O fac-símile do ms foi publicado por Lília Ledon da Silva em "A escritura elucidando a escrita ou evoluções da ortografia em Foot-ball de Sério Milliet" (Revista do Instituto de Estudos Brasileiros, $\mathrm{n}^{\circ}$ 34, São Paulo, p. 211-220). A autora levanta uma hipótese para a data do ms: "Serge' (quando escrevia em francês) ou 'Sérgio' (ao usar o português) mandava a Mário escritos que não eram o rascunho original; Mário, amigo, companheiro e cúmplice, emendava-lhe o português, encorajava-o à prática do 'brasileiro' (empenhado como estava na elaboração da Gramatiquinha), partilhava com ele discussões antropofágicas repletas de citações francesas. Foot-ball chega às mãos de Mário de Andrade entre março e maio de 1923, com toda a sua carga de vanguardismo ortográfico e sua parcela de submissão à confusão normativa reinante no português, mesclada a uma vivência de longos anos na Suíça e em Paris (ou seja a um contato permanente com a língua francesa)".

Estudo genético:

1. No arquivo MA o ms apresenta-se em uma única versão, A, passada a limpo no autógrafo que mostra 2 etapas na escritura: a-a ${ }_{1}$ :

a: autógrafo completo;

$\mathrm{a}_{1}$ : rasuras a tinta preta.

MA - MOE, 224

MILLIET, Sérgio (Sérgio Milliet da Costa e Silva 1898-1966)

224. Poème; poesia (MAd)

[Paris], ant. 26 maio 1923

Autógrafo a lápis preto; papel branco, quadriculado; 1 folha; 21,2 x 13,1/13,5 cm; borda esquerda recortada; vincos; sinal de fungo; escrita no anverso e no verso; rasuras a lápis preto; fólio numerado pela pesquisa: (1) Nota SM a lápis preto: 
embaixo do título: "Les vers sont marqués ainsi | Les sonligués en gros -", no verso à margem inferior: "Pour Klaxon! A ajoutes aprés Ville Lumière | ce vers: | Blaise Cendrars Jean Cocteau CharlesVildrac".

Notas da pesquisa:

1. Ms na vertente Mário de Andrade no diálogo interpares.

2. Data atestada com base na carta a MA, de Paris, 26 de maio de 1923, junto da qual SM envia o ms: "Meu caro Mario, | junto um poema novo para Klaxon." (Ref.: série Correspondência Mário de Andrade - sub-série Correspondência passiva; MA-C-CPL, $\mathrm{n}^{\circ}$ 4880). Poème não alcançou o último número da revista Klaxon do modernista paulistano, cujo último número saiu em janeiro de 1923.

3. A versão em português foi publicada com o título "Expressionismo", em "Poemas análogos", em Poesias (ed. cit.).

\section{Estudo genético:}

1. No arquivo MA o ms apresenta-se em uma única versão, A, que mostra 2 etapas na escritura: $a-a_{1}$ :

a: autógrafo completo;

$\mathrm{a}_{1}$ : rasuras a lápis preto.

\section{MA - MOE, 225}

MILLIET, Sérgio (Sérgio Milliet da Costa e Silva 1898-1966)

225. Cartão postal - Paris; poesia (MAd)

[Paris, ant. 06 jun. 1923]

Datiloscrito original, fita preta e vermelha; papel branco, timbrado: "Drs. A A. C. Couto de Barros | e | Tacito de Almeida | Advogados | Rua Direita, 33 - sala 5 - S. Paulo | tel. Cent. 4098", filigrana; 1 folha; 27,9 x 21,3 cm; vincos; sinais de fungo; escrita no verso; assinatura a máquina no final do poema: "Serge Milliet"; rasuras a máquina; fólio numerado pela pesquisa: (1).

Notas da pesquisa:

1. Ms na vertente Mário de Andrade no diálogo interpares.

2. Local e data atestados com base na carta de SM a MA, de Paris, após 6 de junho de 1923, na qual se lê: "Escrevo Cartões Postaes em portuguez". (Ref.: série Correspondência Mário de Andrade - sub-série Correspondência passiva; MA-C-CPL, $\mathrm{n}^{\mathrm{o}}$ 4882). Até esse momento, o escritor, cujos textos eram assinados Serge Milliet, escrevia em francês.

3. Os poemas foram publicado Poesias (Porto Alegre, O Globo, 1946).

\section{Estudo genético:}

1. No arquivo MA o ms apresenta-se em duas versões: esta, considerada pela pesquisa versão A, no datiloscrito original, mostra 2 etapas na escritura: a-a

a: datiloscrito completo;

$\mathrm{a}_{1}$ : rasuras a máquina. 
2. V. análise documentária da versão B: MA-MOE, 227.

3. A versão A foi confrontada com as versões $\mathrm{B}$, no ms intitulado Paris $I V$, e $\mathrm{C}$, em Poesias (ed. cit.). Há variantes entre as três versões.

\section{MA - MOE, 226}

\section{MILLIET, Sérgio (Sérgio Milliet da Costa e Silva 1898-1966)}

226. Stancias; Ballets Suédois. poesia (MAd)

[Paris, ant. jul.? 1923]

Autógrafo a tinta preta; papel branco, quadriculado, borda superior picotada; 2 folhas; 19,5 x 13,2/13,3 cm; vinco; sinais de fungo; escrita no anverso; assinatura a tinta preta: "Serge Milliet"; rasuras a tinta preta; fólios numerados pela pesquisa: (1)-(2). Notas SM a tinta preta: no final dos poemas: "do livro Paris", f. 2: na margem esquerda: mensagem para MA: "Corrige os pronomes!".

Nota MA a lápis preto: f. 1 na margem superior: "Estancias".

Anexo:

Bilhete de SM a MA; s/ forma de tratamento; assinatura: "Sergio"; autógrafo a tinta preta; papel branco, quadriculado, borda superior picotada; 1 folha; 19,5/19,6 x 13,3 cm; vinco; sinais de fungo; escrita no anverso e no verso; fólio numerado pela pesquisa: (1). O texto refere-se ao título do livro: "O livro em portuguez vai se chamar |, 'Cartõespostaes"”; notícia sobre a tradução de Oeil-de-boeuf; no verso: mensagem com desenhos, fórmula e palavras.

(Ref. cruzada: série Correspondência Mário de Andrade - sub-série Correspondência passiva; MA-C-CPMVA n ${ }^{\circ} 4887$ )

Notas da pesquisa:

1. Ms na vertente Mário de Andrade no diálogo interpares.

2. Local e data atestados com base no bilhete acima citado.

3. A série Stancias apresenta os poemas: I-“Noites de Paris", II-“Crepusculos longos impressionistas" e III-"Paris-mulher".

4. “Crepusculos longos impressionistas", Ballets Suédois foram publicados em Poesias (Porto Alegre, O Globo, 1946).

Estudo genético:

1. No arquivo MA "Noites de Paris" e "Crepusculos longos impressionistas" apresentamse em duas versões. A acima registrada no autógrafo foi considerada pela pesquisa versão A. Na versão B, os dois pemas ganharam, respectivamente os títulos: Paris e Paris II (V. estudo genético em MA-MOE, 227).

2. "Paris-mulher" e Ballets Suédois apresentam-se em uma única versão, A.

3. A versão A mostra 2 etapas na escritura: $\mathrm{a}-\mathrm{a}_{1}$ :

a: autógrafo completo;

$\mathrm{a}_{1}$ : rasuras a tinta preta. 
4. A versão A, confrontada com a versão B em Poesias (ed. cit.), mostra variantes. Dentre as quais se destacam as substituições no título: "Crepusculos longos impressionistas" para "Paris" e Ballets Suédois para "Bailado sueco".

MA - MOE, 227

MILLIET, Sérgio (Sérgio Milliet da Costa e Silva 1898-1966)

227. $1 \$ 000$ a duzia ... | versos de meu amigo philosopho; poesia (MAd)

[Paris, ant. 4 out. 1923]

Datiloscrito original fita preta; datiloscrito original, fita vermelha: título e epígrafe; papel branco, timbrado: "terra roxa | e outras terras | quinzenário | S. Paulo", filigrana; 5 folhas; 28,4 x 21,8 cm; f. 5: rasgamento na borda direita; vincos; sinais de fungo; f. 1: furo; escrita no anverso; rasuras a máquina e alápis preto; fólios numerados pela pesquisa: (1)-(5). Nota SM: f. 5: "Fim de $1 \$ 000$ a duzia | no proximo numero: Poemas analogos | do mesmo autor.

$\underline{\text { Notas MA a lápis vermelho: parenteses na primeira parte do título: " }(\underline{1 \$ 000} \text { a }}$ duzia...)", risco sobre a segunda parte do título: "verses de meu amigo philosephe", circunferência em volta da epígrafe e sinais de " $\mathrm{x}$ " na margem esquerda dos poemas

O conjunto de ms contém os títulos:

Paris, Paris II, Hamburgo, Hamburgo II, Lisboa, Amsterdam, Oberland, Suissa, Paris III, Rio de Janeiro, Paris IV, Hollanda ["Reminiscencias geographicas"], Hollanda ["O sol amarello sobre os gelos brancos"], Vigo, La palmas, Havre, Savoia, Saint Cergue, Genebra, Grenoble, Nova York, Paris V,

Notas da pesquisa:

1. Ms na vertente Mário de Andrade no diálogo interpares.

2. Local e data estabelecidos com base em carta de Paris, 4 de outubro de 1923, na qual SM agradece comentários de MA a poemas, cujos títulos não menciona. mas ao que se pode avaliar, são os acima registrados: "Meu caro Mario, recebi sómente hontem | a carta que enviaste á Tarsila á que | ella, não sabendo o meu endereço exacto, | e estando ainda em Londres, não | me enviára. Agóra que voltou a | Paris remeteu-me-a. merci. Fiquei | contente em saber que gostaste dos | meus versos em portuguez. Tenho continuado" (Ref.: série Correspondência Mário de Andrade - sub-série Correspondência passiva; MA-C-CPL, $\mathrm{n}^{\circ}$ 4890).

3. Os poemas foram publicados em Poesias (ed. cit.).

Estudo genético:

1. No arquivo MA os poemas Paris, Paris II e Paris $I V$ apresentam-se em duas versões, A e B, ambas passadas a limpo: a primeira no autógrafo e a segunda no datiloscrito original. A acima registrada foi considerada pela pesquisa versão B (V. estudo genético em MA-MOE, 225 e MA-MOE, 226). Os demais poemas apresentam-se em versão única, A.

2. Amsterdam, Oberland, Suissa, Paris III, Rio de Janeiro, Havre, Grenoble, Nova York mostram 1 etapa na escritura; Hamburgo, Hamburgo II, Lisboa, Hollanda, Hollanda, 
Vigo, La palmas, Savoia, Saint Cergue, Genebra mostram 2 etapas na escritura: a-a Paris $V$ mostra 3 etapas na escritura: a- $a_{1}-a_{2}$ :

a: datiloscrito completo;

$\mathrm{a}_{1}$ : rasuras a máquina;

$\mathrm{a}_{2}$ : rasura a lápis preto.

3. Paris II mostra 1 etapa na escritura; Paris $I I$ e Paris $I V$ mostram 2 etapas na escritura:

b- $b_{1}$ :

b: datiloscrito completo;

$\mathrm{b}_{1}$ : rasuras a máquina.

4. Há variantes entre as versões A e B de Paris, Paris II e Paris $I V$, no ms, e a versão C, em Poesias (ed. cit.).

5. A versão A dos demais poemas foi confrontada com a versão B em Poesias (ed. cit.). Há variantes em relação à versão $\mathrm{B}$ em Paris, Paris II (na versão B com o título "Paris"), Hamburgo, Hamburogo II (na versão B com o título "Vale do Reno"), Lisboa, Oberland, Suissa, Paris III (na versão B com o título Paris), rio de Janeiro, Paris IV (na versão B com o título "Paris"), Hollanda ["Reminiscencias geographicas"], Hollanda ["O sol amarello sobre os gelos brancos"] ( na versão com o título B "Holanda ainda"], Las Palmas, Saint Cergue, Genebra, Grenoble, Paris V (na versão com o título B "Paris")

6. Entre as versões A e B dos poemas Amsterdam, Vigo, Havre, Savóia, Nova York não há variantes.

7. No livro Poesias (ed. cit.), esta série de poemas acata, no título a sugestão da Nota MA neste ms: $\$ 000$ a duzia.

\section{MA - MOE, 228}

MILLIET, Sérgio (Sérgio Milliet da Costa e Silva 1898-1966)

228. Rimes; "La voici sur son déclin l'Europe"; "France je vois monter en tes veives"; Poema; poesia (MAd)

[Paris, 1924]

Autógrafo a tinta preta; papel cinza; 2 folhas; f. 1: $22,8 / 23,3$ x 21,4/21,5 cm; f. $2: 27,0$ x 21,4 cm; f. 1: borda superior cortada; vincos; sinais de fungo; escrita no anverso e no verso; f. 1: no verso à margem esquerda: assinatura: "Serghei Milliet" e comentário: "(Du [?] et du perroquet)"; rasuras a tinta preta; fólios numerados pela pesquisa: (1) (2).

\section{Rimes:}

Assinatura no final do poema: "Sergehei Milliet"; bilhete a MA em autógrafo a tinta preta acima do poema: "Este é o poema que deu origem ao em portugues | que te enviei uma vez. Vai apparecer no (Lucifer)".

Poema:

Assinatura no final do poema: "Sergio Milliet". 
Notas da pesquisa:

1. Ms na vertente Mário de Andrade no diálogo interpares.

2. Apenas Poema encontra-se publicado: em Poesias, na série "Poemas análogos" (ed. cit.). No livro 1924 é dado como o ano de criação dos poemas desta série.

\section{Estudo genético:}

1. No arquivo MA o ms apresenta-se em uma única versão, A, passada a limpo no datiloscrito, mostra 2 etapas na escritura: $\mathrm{a}-\mathrm{a}_{1}$ :

a: autógrafo completo;

$\mathrm{a}_{1}$ : rasuras a tinta preta.

2. A versão A de Poema, confrontada com a versão B em Poesias (ed. cit.), exibe variantes.

\section{MA - MOE, 229}

\section{MILLIET, Sérgio (Sérgio Milliet da Costa e Silva 1898-1966)}

229. Roberto; Linda; Cabeça de póte; romance e contos, respectivamente (MAm)

São Paulo, 1933

Volume manufaturado com a forma de livro que reúne o romance e dos dois contos: caderno capa dura, revestida com papel estampado em vermelho, azul e amarelo; 29,2 x 21,8 cm; guarda em papel beje; perfuração de inseto na borda inferior da guarda: $\mathrm{f}$. 1; lombada: em papel percalux cor de vinho, com impresso em dourado: "S. MILLIET/ ROBERTO"; miolo: datiloscrito, cópia carbono preto; papel branco, tipo seda; 159 folhas; 28,2 x 20,5 cm; f. 1-8: perfuração de inseto na borda esquerda inferior; f. 1: rasgamento na borda inferior; sinal de folha arrancada entre f. 121-122; sinais de fungo; manchas de carbono; f. 28: mancha de tinta preta no verso; escrita no anverso; f. 1: autoria, título, local e data: "Sergio Milliet | Roberto | S.Paulo - 1933", dedicatória em autógrafo a tinta vermelha: "Tirado a seis exemplares | Ex. $n^{\circ} 4$ |que Sergio Milliet | oferece | a | Mario de Andrade", e selo de identificação na biblioteca de Mário de Andrade: "A/II/e/38"; f. 2: relação de obras do escritor; f. 141: título e gênero: "LINDA | (conto)"; f. 151: título e gênero: "CABEÇA DE PÓTE | conto"; f. 158: assinatura rasurada a tinta vermelha: "Sollief";folhas numeradas pelo escritor: 1-22, 41, 43-136; rasuras a máquina, a tinta vermelha e a tinta preta; fólios numerados pela pesquisa: (1)-(1) (6) (1).

\section{Notas da pesquisa:}

1. Ms na vertente Mário de Andrade colecionador.

2. Roberto foi publicado em 1935 (São Paulo, L. Niccolini \& Cia.). MA guardou dois exemplares em sua biblioteca, um deles com a dedicatória: "Para Mario de | Andrade, com o | abraço do | Sergio Milliet", o outro com notas a lápis preto.

3. Os contos permaneceram inéditos. 
Estudo genético:

1. O ms apresenta-se me uma única versão, A.

2. Roberto mostra 4 prováveis etapas na escritura: $a-a_{1}-a_{2}-a_{3}$ :

a: datiloscrito completo;

$\mathrm{a}_{1}$ : rasuras a máquina;

$\mathrm{a}_{2}-\mathrm{a}_{3}$ : rasuras a tinta vermelha e a tinta preta.

3. Linda e Cabeça de póte mostram 3 etapas na escritura: $\mathrm{a}-\mathrm{a}_{1}-\mathrm{a}_{2}$ :

a: datiloscrito completo;

$\mathrm{a}_{1}$ : rasuras a máquina;

$\mathrm{a}_{2}$ : rasuras a tinta vermelha.

4. Há variantes entre a versão A e a versão B, Roberto (ed. cit.).

MA - MOE, 230

MILLIET, Sérgio (Sérgio Milliet da Costa e Silva 1898-1966)

230. Thomazina; Fazenda dos Suecos; A seriema; poesia (MAd)

[São Paulo], s/ data

Autógrafo a tinta azul; papel branco, quadriculado, cantos arredondados; 1 folha; 22,1 x 17,1 cm; vincos; sinais de fungo; 2 furos na margem esquerda para arquivamento; rasgamento nos furos; escrita no anverso e no verso; fólio numerado pela pesquisa:

(1). NotaSM. Notas MA.

\section{Thomazina:}

Assinatura a tinta azul no final do poema: "Sergio Milliet" Nota SM a tinta azul no final do poema: "vire": indicando outros dois poemas no verso.

Nota MA a lápis vermelho: marcação ao lado esquerdo do título: " $x$ ".

Fazenda dos Suecos:

Nota MA a lápis vermelho: marcação ao lado esquerdo do título: "x".

A seriema:

Assinatura a tinta azul no final do poema: "Sergio Milliet".

Nota MA a lápis vermelho: marcação ao lado esquerdo do título: " $x$ ".

Notas da pesquisa:

1. Ms na vertente Mário de Andrade no diálogo interpares.

2. Os poemas foram publicados em Poesias (ed. cit.).

\section{Estudo genético:}

1. No arquivo MA o ms apresenta-se em uma única versão, A, passada limpo no autógrafo que mostra nos poemas Thomazina, A seriema 1 etapa na escritura, e no poema Fazenda dos Suecos 2 etapas na escritura: a-a a $_{1}$

a: autógrafo completo;

$\mathrm{a}_{1}$ : rasura a tinta azul.

2. A versão A confrontada com a versão B, em Poesias (ed. cit.), mostra variantes. 
MA - MOE, 231

MILLIET, Sérgio (Sérgio Milliet da Costa e Silva 1898-1966)

231. Contre les vers d'amour; poesia (MAd)

$\mathrm{S} /$ local, s/ data

Autógrafo a lápis tinta; papel branco; 1 folha; 26,9 x 20,8 cm; vincos; sinais de fungo; escrita no anverso; assinatura: Serge Milliet; fólio numerado pela pesquisa: (1).

Nota da pesquisa:

1. Ms na vertente Mário de Andrade no diálogo interpares.

Estudo genético:

1. No arquivo MA o ms apresenta-se em uma única versão, A, passada a limpo no autógrafo que mostra 1 etapa na escritura.

MA - MOE, 232-238

MIRANDA, Murilo (1912-1971)

232. Canção; poesia (MAm)

[Rio de Janeiro, ant. 7 mar. 1942]

Datiloscrito, cópia carbono roxo; papel branco, filigrana; 1 folha; 20,9/21,2 x 7,0/8,8 $\mathrm{cm}$; bordas esquerda, direita e superior recortadas; vincos; sinais de fungo; furos de grampeador no canto superior esquerdo; escrita no anverso; rasuras a lápis e a tinta preta; fólio numerado pela pesquisa: (1).

233. A distante presença; poesia (MAm)

[Rio de Janeiro, ant. 7 mar. 1942]

Datiloscrito original, fita azul; papel pardo; 1 folha; 19,3/19,4 x 13,9/14,3 cm; borda esquerda cortada; vincos; sinais de fungo; furos de grampeador no canto superior esquerdo; escrita no anverso; rasuras a máquina; fólio numerado pela pesquisa: (2).

234. Elevação; poesia (MAm)

[Rio de Janeiro, ant. 7 mar. 1942]

Datiloscrito original, fita azul; papel pardo; 1 folha; 11,9/12,0 x 17,5/18,1 cm; bordas esquerda, superior e inferior recortadas; vincos; sinais de fungo; furos de grampeador no canto superior esquerdo; escrita no anverso; rasuras a máquina, a tinta preta; fólio numerado pela pesquisa: (3).

235. Abismo; poesia (MAm)

[Rio de Janeiro, ant. 7 mar. 1942]

Impresso; papel branco, recorte de periódico; 1 folha; 10,9 x 11,3 cm; bordas esquerda e inferior recortadas; sinais de fungo; furos de grampo no canto superior esquerdo; margem superior: título do periódico: Revista Acadêmica ; fólio numerado pela pesquisa: (4). 
236. Beijos; poesia (MAm)

[Rio de Janeiro, ant. 7 mar. 1942]

Impresso; papel branco, recortes de revista; 3 folhas; f. 1: 16,5/17,2 x 14,5/14,9 cm, f. 2: 12,3/12,5 x 14,6/14,8 cm, f. 3: 11,6/12,5 cm; bordas superior, esquerda e inferior recortadas; vinco; sinais de fungo; furos de grampeador no canto superior esquerdo; $\mathrm{f}$. 2: autoria em impresso: "Murilo Miranda"; rasuras a tinta preta; fólios numerados pela pesquisa: (5)-(7).

237. Momento; poesia (MAm)

[Rio de Janeiro, ant. 7 mar. 1942]

Impresso; papel branco, recorte de periódico; 1 folha; 8,5/9,0 x 13,4/13,8 cm; bordas esquerda, superior e inferior recortadas; furos e ferrugem de grampo no canto superior esquerdo; fólio numerado pela pesquisa: (8).

238. Os violões; poesia (MAm)

[Rio de Janeiro, ant. 7 mar. 1942]

Impresso; papel branco, recorte de periódico; 1 folha; 10,3/10,9 x 14,5/15,1 cm; bordas esquerda, superior e inferior recortadas com tesoura; canto superior esquerdo: furos e ferrugem de grampo; margem superior: título do periódico: Revista Acadêmica; fólio numerado pela pesquisa: (9).

Anexo:

Carta de MuM a MA; [Rio de Janeiro, ant. 7 mar. 1942]; forma de tratamento: "Mario"; assinatura: "Saudades do | Murilo"; datiloscrito original, fita azul; papel pardo, tipo jornal dobrado ao meio formando 2 folhas; 24,4/24,5 x 16,5/16,6 cm; rasgamentos nas bordas; furos na borda inferior; vincos; sinais de fungo; furos causados pela máquina na digitação da letra "o"; ferrugem de grampo no canto superior esquerdo; escrita no anverso e no verso; rasuras a máquina e a tinta preta; fólios numerados pela pesquisa: (1)-(2).

(Ref. cruzada: série Correspondência Mário de Andrade; sub-série Correspondência passiva)

Notas da pesquisa:

1. Ms na vertente Mário de Andrade mentor.

2. Data atestada com base na carta acima registrada, na qual se lê: "Queria lhe fazer uma consulta, Mario: voce acha | que eu daqui a uns tempos poderia fazer a minha an- | tologia, sem ridiculo? As poesias que eu | publicaria seriam as que lhe remeto juntamente. Dei- | 'O violões'só para mostrar que não sei fazer verso,... | Mas, no caso de você achar que sim, então es- | cute uma coisa. Me sinto muito à margem [...]".

3. Os poemas permaneceram inéditos.

4. O ms com o título Beijos agrega três poemas de Murilo Miranda que saíram separadamente em revistas.

5. Entre 1938 e 1941, período em que MA residiu no Rio de Janeiro, MuM encaminhoulhe manuscritos e recortes de poemas que publicava em jornais. 
Estudo genético:

1. O ms apresenta-se em uma única versão, A.

2. Canção mostra 3 etapas na escritura: $\mathrm{a}-\mathrm{a}_{1}-\mathrm{a}_{2}$ :

a: datiloscrito completo;

$\mathrm{a}_{1}$ : rasura a lápis preto;

$\mathrm{a}_{2}$ : rasura a tinta preta.

3. A distante presença mostra 2 etapas na escritura: $\mathrm{a}-\mathrm{a}_{1}$ :

a: datiloscrito completo;

$\mathrm{a}_{1}$ : rasuras a máquina.

4. Elevação mostra 3 etapas na escritura: $\mathrm{a}-\mathrm{a}_{1}-\mathrm{a}_{2}$ :

a: datiloscrito completo;

$\mathrm{a}_{1}$ : rasura a máquina;

$\mathrm{a}_{2}$ : rasura a tinta preta.

5. Beijos, mostra 2 etapas na escritura: $\mathrm{a}-\mathrm{a}_{1}$ :

a: impresso;

$a_{1}$ : rasuras a tinta preta.

6. Abismo, Momento, Os violões apresentam 1 etapa na escritura: impresso.

7. Os poemas impressos são considerados manuscritos porque foram selecionados pelo escritor com a finalidade de enviá-los a MA e porque o poema Beijo, recebeu rasuras de MuM.

MA - MOE, 239

MIRANDA, Murilo

239. "Com 'Aspectos da Literatura Brasileira', de Mario de Andrade, a Americ="; prefácio (MAm)

[Rio de Janeiro, ant. 1943]

Datiloscrito original, fita preta; papel branco, filigrana; 2 folhas; 28,2/28,3 x 22,0 cm; vincos; marca de clipe; f. 1: sinais de fungo; f. 2 marca do texto datilografado na f. 1 ; escrita no anverso; f. 2: assinatura a lápis preto: "Murilo Miranda"; rasuras a máquina e a lápis preto; fólios numerados pela pesquisa: (1)-(2).

Notas da pesquisa:

1. Ms na vertente Mário de Andrade mentor.

2. Data atestada com base no ano de publicação do livro de MA Aspectos da literatura brasileira (Rio de Janeiro, Americ= edit., 1943)

\section{Estudo genético:}

1. Ms apresenta-se em uma única versão, $A$, que mostra 3 etapas na escritura: $a-a_{1}-a_{2}$ : a: datiloscrito completo;

$\mathrm{a}_{1}$ : rasuras a máquina;

$\mathrm{a}_{2}$ : rasura a lápis preto. 
MA - MOE, 240

MIRANDA, Nicanor (Nicanor Teixeira de Miranda, 1907-?)

240. Classificações das idades; pesquisa (MAc)

[São Paulo, 1937 ou ant. 1937]

Datiloscrito original, fita preta; papel branco; 5 folhas; $31,7 / 31,8$ x 21,9 cm; vincos; sinais de fungo; f. 1: furos e ferrugem de grampo na margem esquerda; f. 2-5: furos de grampo na margem esquerda; escrita no anverso; f. 1: folha de rosto com título: "Classificações das idades"; f. 2: assinatura: "Nicanor" e etiqueta de MA para identificação de exemplares em sua biblioteca: "C/II/d/171"; f. 4-5 numeradas pelo escritor: 2-3.; rasuras a máquina e a tinta preta; fólios numerados pela pesquisa: (1)-(5). Notas MA: f. 1: na margem superior: a lápis vermelho: "Desenho infantil", abaixo a lápis preto: "MIRANDA, Nicanor"; na margem inferior a lápis preto: bilhete MA a José Bento Faria Ferraz, seu secretário: "Colocar em Desenho Infantil ou | ficha de nome parecido que tenho | no fichário organizado por mim | em Artes Plasticas | Colocar noutros lugares possiveis fichas | remissivas".

\section{Anexo:}

Carta de NM a MA; não datada; forma de tratamento: "Mário."; visto do escritor a lápis tinta; datiloscrito original, fita preta; papel branco; 3 folhas; 31,7/31,8 x 21,9 $\mathrm{cm}$; vincos; sinais de fungo; furos de grampo na margem esquerda; escrita no anverso; folhas numeradas pelo escritor: 2-3; rasuras a máquina, a tinta preta e a lápis tinta; fólios numerados pela pesquisa: (1)-(3).

(Ref. cruzada: série Correspondência Mário de Andrade - sub-série Correspondência passiva; MA-C-CPMVA, $\mathrm{n}^{\circ}$ 5151)

Notas da pesquisa:

1. Ms na vertente Mário de Andrade colecionador.

2. No ms encontra-se pesquisa realizada por $\mathrm{NMi}$, constituída por tabelas com especificações das faixas etárias do desenvolvimento humano, desde a primeira infância até a juventude. Foi uma contribuição para o estabelecimento de um concurso de desenhos infantis que MA organizou, em 1937, como Secretário do Departamento de Cultura da Prefeitura do Município de São Paulo.

3. A data do ms foi atestada com base no ano em que aconteceu concurso de desenhos.

4. NMi foi chefe da Divisão de Educação e Recreio do Departamento de Cultura no mandato do prefeito Fábio Prado, época em que MA exercia o cargo de Secretário do mesmo Departamento.

5. Na carta, além de NMi explicar o tema da pesquisa e método de escolha bibliográfica, expõe o motivo da colaboração: "Juntando aqui os varios critérios das ida- | des lembrei-me de dar-lhe uma pequena contribuição que talvez | lhe possa ser util. [...] Pareceu-me, de bom aviso, dar esta pequenina | contribuição a v. para, considerando esses fatores, proce- $\mid$ der a uma anlise interssante e proferir um juizo seguro so- $\mid$ bre o concurso de desenhos." 
Estudo genético:

1. O ms apresenta-se em uma única versão, $A$, que mostra 3 etapas na escritura: $a-a_{1}-a_{2}$ : a: datiloscrito completo;

$\mathrm{a}_{1}$ : rasuras a máquina;

$\mathrm{a}_{2}$ : rasuras a tinta preta.

\section{MA - MOE, 241}

MORAES, Aldo

241. Scenarios da Amazoni;. Pathé-Jornal-da-imaginativa; poesia (MAm)

Manaus, 25 set. 1929

Datiloscrito original, fita preta; papel branco, filigrana em alto-relevo; 1 folha; $31,6 \mathrm{x}$ 21,8/22,1 cm; rasgamentos na borda esquerda; vincos; sinais de fungo; escrita no anverso; assinatura a máquina em baixo do título: "operador | ALDO MORAES"; local e data a tinta preta: "Manáos, 25/9/29"; assinatura a tinta preta: "Aldo Moraes"; rasuras a máquina; fólio numerado pela pesquisa: (1).

Notas da pesquisa:

1. Ms na vertente Mário de Andrade mentor.

2. Não há carta de AdM a MA que comprove o envio do ms.

3. As poesias no ms são inéditas.

Estudo genético:

1. O ms apresenta-se em uma única versão, $A$, que mostra 2 etapas na escritura: $a_{1}-a_{2}$ $\mathrm{a}_{1}$ : datiloscrito completo

$\mathrm{a}_{2}$ : rasuras a máquina

MA - MOE, 242

MORAIS NETO, Prudente de (Francisco de Paula Prudente Moraes Neto 1904-1977)

242. Suicidio; poesia (MAm)

Rio de Janeiro, 24 nov. 1925

Ms no corpo da carta de PMN a MA: datada: "Rio, 24-11-925"; s/ forma de tratamento; assinatura: "Prudente"; autógrafo a tinta preta; papel branco, pautado; 2 folhas; 25,2/25,3 x 20,4 cm; vincos; sinais de fungo; f. 1: rasgamento no local do vinco horizontal; f. 1: escrita no anverso e no verso, f. 2: escrita no anverso; rasuras a tinta preta; fólios numerados pela pesquisa: (1)-(2).

(Ref. cruzada: série Correspondência Mário de Andrade - sub-série Correspondência passiva: MA-C-CPMVA, $n^{\circ}$ 5265) 
Anexo:

Envelope branco; 12,4 x 15,5/15,6 cm; vinco; sinais de fungo; fólio numerado pela pesquisa: (1).

Nota MA a lápis preto: "Prudentico".

Notas da pesquisa:

1. Ms na vertente Mário de Andrade mentor.

2. Na carta acima registrada, PMN escreve: "Ando com uns dois romances na cabeça mas não sei o que | póde sair daí. Estou procurando úa maneira que pelo menos | não me desagrade de todo. Poema, só fiz mais um, plágio | ao mesmo tempo do Oswaldo e do Globo. Isolei umas frases | de um fedivér do Globo e pronto. É assim:".

3. O poema permaneceu inédito.

Estudo genético:

1. O ms apresenta-se em uma única versão, A, que mostra 1 etapa na escritura.

MA - MOE, 243

MORAIS NETO, Prudente de (Francisco de Paula Prudente Moraes Neto 1904-1977)

243. A cachorra; poesia (MAc)

[Rio de Janeiro], s/ data

Autógrafo a tinta preta; papel branco, pautado; 1 folha; 33,0 x 22,0 cm; rasgamentos nas bordas superior, esquerda e inferior; vincos; sinais de fungo; escrita no anverso e no verso; rasuras a tinta preta, a lápis preto e a lápis tinta; fólio numerado pela pesquisa: (1).

Anexo:

Pasta improvisada por MA para acondicionamento do ms: papel tipo almaço branco, timbrado: "Congresso da Lingua Nacional Cantada", filigrana: "VERA CRUZ"; 2 folhas; 31,9/32,0 x 22,0 cm; sinais de fungo; f. 1: risco de lápis azul no verso da capa; fólios numerados pela pesquisa: (1)-(2).

Nota MA a tinta preta: título e autoria: "Original do poema | 'A Cachorra' | de | Prudente de Moraes Neto".

Notas da pesquisa:

1. Ms na vertente Mário de Andrade colecionador.

2. O poema no ms permaneceu inédito.

\section{Estudo genético:}

1. O ms apresenta-se em uma única versão, A, que mostra 4 prováveis etapas na escritura: $a-a_{1}-a_{2}-a_{3}$ :

a: autógrafo completo;

$a_{1}, a_{2}, a_{3}$ : rasuras a tinta preta, a lápis preto, a lápis tinta. 
MA - MOE, 244

MORAIS NETO, Prudente de (Francisco de Paula Prudente Moraes Neto 1904-1977)

244. "Cansaço nas estradas poeirentas"; poesia (MAm)

[Rio de Janeiro], s/ data

Datiloscrito, cópia carbono roxo; papel branco, tipo seda; 1 folha; 28,2 x 21,6 cm; rasgamentos na borda direita; vincos; sinais de fungo; rasgamento na parte superior central da folha; escrita no anverso; rasuras a máquina e a lápis preto; fólio numerado pela pesquisa: (1).

Nota MA: assinatura a máquina no final do poema: "Prudente de Morais neto"

Notas da pesquisa:

1. Ms na vertente Mário de Andrade mentor.

2. O poema permaneceu inédito.

Estudo genético:

1. O ms apresenta-se em uma única versão, A, que mostra 3 etapas na escritura: $a-a_{1}-a_{2}$ : a: datiloscrito completo;

$\mathrm{a}_{1}$ : rasuras a máquina;

$\mathrm{a}_{2}$ : rasuras a lápis preto.

\section{MA - MOE, 245}

MOURA, Nídia

245. À procura de uma toante; Bonança; Cristais; Eu e o bandolim; Fim de maio na serra; Fuga; "Helsingfors!"; Noturno; Poema; Tempo; poesia (MAm)

[Rio de Janeiro, junho 1939]

Datiloscrito original, fita preta e vermelha; papel rosa; 12 folhas; $23,5 \times 16,3 \mathrm{~cm}$; vincos; sinais de fungo; f. 6: pequena mancha de cola na margem inferior à esquerda; f. 11: ferrugem de clipe no verso; escrita no anverso; folhas numeradas pela escritora; rasuras a máquina; fólios numerados pela pesquisa: (1)-(1) (2).

À procura de uma toante:

Epígrafe: "(Na entrada do Ano)".

Anexo:

Carta de NMo a MA; datada: "Rio, 23 de junho de 1939"; forma de tratamento: "Mario de Andrade,"; assinatura: "Nidia Moura."; datiloscrito original, fita preta; papel rosa; 1 folha; 23,5 x 16,3 cm; vincos; sinais de fungo; margem superior: ferrugem de clipe; escrita no anverso; fólio numerado pela pesquisa: (1)-(1) (3). (Ref. cruzada: série Correspondência Mário de Andrade - sub-série Correspondência passiva: MA-C-CPMVA, $n^{\circ}$ 5352) 
Notas da pesquisa:

1. Ms na vertente Mário de Andrade mentor.

2. A data do manuscrito foi atestada com base na carta acima registrada, na qual se lê: "Ao enviar algumas das coisas que es- | crevo poderá pensar na minha confusão entre | compreender e tolerar. Se assim for, conti- | nue cada vez mais musical, comunicandome a | dissonância".

3. Os poemas não se encontram publicados.

\section{Estudo genético:}

1. Ms apresenta-se em uma única versão, A, que mostra em Bonança, Cristais, Fim de maio na serra, Fuga, "Helsingfors!", Noturno e Poema 1 etapa na escritura, e em $\grave{A}$ procura de uma toante e Eu e o bandolim 2 etapas na escritura: a-a $\mathrm{a}_{1}$ :

a: datiloscrito completo;

$\mathrm{a}_{1}$ : rasura a máquina.

\section{MA - MOE, 246-247}

NAVA, Pedro (Pedro Nava da Silva 1903-1984)

246. Aterrissage; poesia (MAm)

[Belo Horizonte, ant. 17 fev. 1925]

Datiloscrito original, fita preta; papel branco, filigrana; 1 folha; 28,0 x 21,6 cm; vincos; sinais de fungo; escrita no anverso; assinatura do escritor a tinta preta; rasuras a máquina e a lápis preto; fólio numerado pela pesquisa: (1).

Nota MA a lápis preto: sugestão de substituição do título: Aterrissage para "Aterreagem".

247. Reflexos; poesia (MAm)

[Belo Horizonte, ant. 17 fev. 1925]

Datiloscrito original, fita preta; título em autógrafo a tinta preta; papel branco, filigrana; 2 folhas; 32,6 x 21,9 cm; borda direita recortada; vincos; sinais de fungo; manchas de carbono com marcas de polegar na margem direita; escrita no anverso; $f$. 2: assinatura a tinta preta; rasuras a máquina; fólios numerados pela pesquisa: (1)-(2).

Notas da pesquisa:

1. Ms navertente Mário de Andrade mentor.

2. Data e local atestados com base na carta de PN a MA, de Belo Horizonte em 17 de fevereiro de 1925, junto da qual são enviados os poemas Aterrissage e Reflexos. (Ref.: série Correspondência Mário de Andrade - sub-série Correspondência passiva; MA-CCPL, $n^{\circ} 5413$ )

3. MA analisa os poemas em carta a PN, de São Paulo em 9 de março de [1925] (ANDRADE, MÁRIO. Correspondente contumaz. Fernando da Rocha Peres org., notas Pedro Nava. Rio de Janeiro, Nova Fronteira, 1982, p. 37-42).

4. Na carta de 3 de julho de 1925 PN responde à análise de MA (Ref.: série Correspondência Mário de Andrade - sub-série Correspondência passiva; MA-C-CPL, $n^{\circ}$ 5414). 
5. Sobre os poemas que enviava a MA, PN escreve em Correspondente contumaz (ed. cit.), p. 44, nota 7: "Eu bombardeava Mário de Andrade com todos os maus poemas que me saíam da cachola servilamente escritos em língua mariodeandrade. Não tenho cópia da minha produção poética desse tempo; se dela existisse vestígio, ai de mim! será no arquivo da correspondência dele. Às produções que lhe eram enviadas, Mario fazia longos e pacientes comentários como pode ser verificado em toda sua correspondência ativa aos literatos do Brasil naqueles anos vinte. Ele desenvolvia uma fabulosa ação de assistência intelectual, de companheirismo, de amizade e ensino através de suas cartas".

6. PN não chegou a publicar os seus poemas, mas sua criação poética ser conhecida em: BANDEIRA, Manuel. Antologia dos poetas bissextos (1940) e BANDEIRA, Manuel e CAVALHEIRO, Edgar. Obras-primas da poesia brasileira (1957).

Estudo genético:

1. Os ms apresentam-se em uma única versão, A, que mostra em Reflexos 2 etapas na escritura: $\mathrm{a}-\mathrm{a}_{1}$, e em Aterrissage 3 etapas na escritura: $\mathrm{a}-\mathrm{a}_{1}-\mathrm{a}_{2}$ :

a: datiloscrito completo;

$\mathrm{a}_{1}$ : rasuras a máquina;

$\mathrm{a}_{2}$ : rasuras a lápis preto.

MA - MOE, 248

NAVA, Pedro (Pedro Nava da Silva 1903-1984)

248. Cantares da infancia; poesia (MAm)

[Belo Horizonte] jun. 1925

Datiloscrito original, fita vermelha; papel branco, filigrana: "HANDELSBANK"; 2 folhas; f. 1: $32,2 \times 21,7 / 22,0 \mathrm{~cm}$, f. 2: $32,2 \times 21,8 / 21,9 \mathrm{~cm}$; f. 1: borda direita recortada; f. 2: borda esquerda recortada; vincos; sinais de fungo; escrita no anverso; assinatura a tinta preta; rasuras a máquina e a tinta preta; fólios numerados pela pesquisa: (1)-(2).

O conjunto de ms apresenta os títulos:

Bão-ba-la-lão:

Data no final do poema: "Junho 1925".

Nôite de são joão:

Dedicatória no final do título: "a Mario de Andrade".

Anexo:

Envelope papel branco; 12,6 x 15,5 cm; sinais de fungo; fólio numerado pela pesquisa: (1).

Nota MA a lápis preto: "Pedro Nava". 
Notas da pesquisa:

1. Ms na vertente Mário de Andrade mentor.

2. Na carta a PN, de 21 de julho de 1925, MA analisa os poemas Bão-ba-la-lão e Nôite de são joão. (Correspondente contumaz ed. cit., p. 53-56)

3. O envelope em anexo foi providenciado por MA para acondicionar ms de PN.

4. PN relata sobre o envio de seus poemas a MA (V. MA-MOE, 246-247, nota 5).

5. Sobre os poemas de PN publicados, V. MA-MOE, 246-247, nota 6.

\section{Estudo genético:}

1. O ms apresenta-se em uma única versão, A, que mostra em Nôite de são joão 2 etapas na escritura: a- $a_{1}$, e em Bão-ba-la-lão 3 etapas na escritura: $\mathrm{a}_{-} \mathrm{a}_{1}, \mathrm{a}_{2}$ :

a: datiloscrito completo;

$\mathrm{a}_{1}$ : rasura a máquina;

$\mathrm{a}_{2}$ : rasura a tinta preta.

MA - MOE, 249-250

NAVA, Pedro (Pedro Nava da Silva 1903-1984)

249. Noturno de Chopin; poesia (MAm)

[Belo Horizonte, ant. 19 mar. 1926?]

Datiloscrito original, fita azul; papel rosa, filigrana: "HAMMERMILL BOND"; $28,1 \mathrm{x}$ $21,6 \mathrm{~cm}$; vincos; sinais de fungo; escrita no anverso; assinatura a tinta preta; rasura a máquina; fólio numerado pela pesquisa: (1).

250. Ventania:

[Belo Horizonte, ant. 19 mar. 1926]

Datiloscrito original, fita azul; papel rosa, filigrana: "HAMMERMILL BOND"; $28,1 \mathrm{x}$ $21,6 \mathrm{~cm}$; vincos; sinais de fungo; escrita no anverso; assinatura a tinta preta; rasuras a máquina; fólio numerado pela pesquisa: (2).

Notas da pesquisa:

1. Ms na vertente Mário de Andrade mentor.

2. Data atestada com base na carta de MA a PN, de São Paulo em 19 de março de 1926, onde desculpa-se por ter citado integralmente, sem a autorização de PN, o poema Ventania em um artigo seu para a revista Mocidade (Correspondente contumaz, ed. cit., p. 65-68), o que significa que nessa época o ms já estava em suas mãos. Pela semelhança do papel e da escrita, Noturno de Chopin foi redigido na mesma data que Ventania.

3. Na edição que reúne as cartas de que recebera de MA, PN escreveu sobre o seu poema Ventania: "Outro poema de minha autoria que repudio com a maior energia, infelizmente foi conservado pois saiu publicado na Verde, de Cataguazes, número de novembro de 1927" (Correspondente contumaz, ed. cit., p. 70, nota 44).

4. PN relata sobre o envio de seus poemas a MA (V. MA-MOE, 246-247, nota 5).

5. Sobre os poemas de PN publicados, V. MA-MOE, 246-247, nota 6. 
Estudo genético:

1. Os ms apresentam-se em uma única versão, $A$, que mostra 2 etapas na escritura: a-a $a_{1}$ : a: datiloscrito completo;

$\mathrm{a}_{1}$ : rasuras a máquina.

MA-MOE, 251

NAVA, Pedro (Pedro Nava da Silva 1903-1984)

251. Si eu soubesse brincar; poesia (MAc)

[Belo Horizonte], 29 dez. 1926

Impresso; recorte de jornal; 1 folha; 12,3/12,4 x 12,1/12,5 cm; bordas recortadas; vinco; fólio numerado pela pesquisa: (1).

Nota MA a lápis preto embaixo do título: periódico onde saiu o poema e data: "Diario de Minas | 29-XII-26".

Notas da pesquisa:

1. Ms na vertente Mário de Andrade colecionador.

2. Na correspondência de PN e MA não há menção ao envio do recorte.

3. Há outro recorte com o mesmo poema no Arquivo MA (V. MA-MOE, 254).

4. PN relata sobre o envio de seus poemas a MA. (V. MA-MOE, 246-247, nota 5)

5. Sobre os poemas de PN publicados, V. MA-MOE, 246-247, nota 6.

Estudo genético:

1. Há duas verões de Si eu soubesse brincar neste catálogo. A acima registrada foi considerada versão A pela pesquisa, e mostra 1 etapa na escritura. V. a análise documentária da versão B: MA-MOE, 254.

2. Há variantes entre as versões A e B.

MA - MOE, 252-253

NAVA, Pedro (Pedro Nava da Silva 1903-1984)

252. Preludio numero um; poesia (MAm)

[Belo Horizonte, ant. 27 jan. 1927]

Datiloscrito original, fita preta; papel branco, filigrana; 4 folhas; 21,9 x 16,4 cm; f. 13: bordas direita e inferior recortadas; f. 4: bordas superior e esquerda recortadas; vincos; sinais de fungo; escrita no anverso; f. 1: dedicatória em autógrafo a tinta preta: "Ao Emilio Moura"; folhas numeradas pelo escritor a tinta preta: 2-4; fólios numerados pela pesquisa: (1)-(4).

Notas MA a lápis preto: grifos, observação e correções. 
253. Educação sentimental; poesia (MAm)

[Belo Horizonte, ant. 27 jan. 1927?]

Datiloscrito original, fita preta; papel branco, filigrana; $22,0 \times 16,4 / 16,5 \mathrm{~cm}$; bordas direita e inferior recortadas; vincos; sinais de fungo; escrita no anverso; dedicatória: "Para o Alberto Deodato"; autoria no final do poema: "Pedro Nava"; fólio numerado pela pesquisa: (1).

Notas da pesquisa:

1. Ms na vertente Mário de Andrade mentor.

2. Data e local atestados com base nas cartas: a) de PN a MA, de Belo Horizonte em 27 de janeiro de 1927. Nela o remetente comenta o envio de poema Preludio. (Ref.: série Correspondência Mário de Andrade - sub-série Correspondência passiva; MA-C-CPL, $n^{\circ}$ 5414), b) de MA a PN, de São Paulo em 10 de abril de 1927, na qual comenta o recebimento dos poemas nos $\mathrm{ms}$, sem mencionar título, e faz uma análise a Preludio numero um (Correspondente contumaz, ed. cit., p. 87-91). Provavelmente Educação sentimental foi também encaminhado a MA junto da carta de 27 de janeiro de 1927.

3. PN relata sobre o envio de seus poemas a MA. (V. MA-MOE, 246-247, nota 5)

4. Sobre os poemas de PN publicados, V. MA-MOE, 246-247, nota 6.

Estudo genético:

1. Os ms apresentam-se em uma única versão, A, que mostra 1 etapa na escritura.

MA - MOE, 254

NAVA, Pedro (Pedro Nava da Silva 1903-1984)

254. Se eu soubesse brincar...; poesia (MAc)

[Rio de Janeiro, 25 dez. 1927]

Impresso; recorte de jornal; 1 folha; 29,2/29,4 x 15,7/16,1 cm; bordas recortadas; vincos; sinais de fungo; ilustração de Di Cavalcanti; fólio numerado pela pesquisa: (1). Nota MA a lápis preto embaixo do título: título do periódico onde saiu o poema e data: "O Jornal 25-XII-27".

Notas da pesquisa:

1. Ms na vertente Mário de Andrade colecionador.

2. Na correspondência de PN e MA não há menção ao envio do recorte.

3. Há outro recorte com o mesmo poema no Arquivo MA (V. MA-MOE, 251).

4. PN relata sobre o envio de seus poemas a MA (V. MA-MOE, 246-247, nota 5).

5. Sobre os poemas de PN publicados, V. MA-MOE, 246-247, nota 6.

Estudo genético:

1. Há duas versões de Si eu soubesse brincar.... A acima registrada apresenta-se em versão $\mathrm{B}$, que mostra 1 etapas na escritura. A análise documentária da versão A está neste catálogo: MA-MOE, 251.

2. Há variantes entre as versões A e B. 
MA - MOE, 255

OLIVEIRA, Armando de

255. Canção em honra de uma rosa; poesia (MAc)

São Paulo, jan. 1935

Datiloscrito original, fita preta; papel branco, borda superior picotada; 1 folha; 31,6 x 12,0 cm; vincos; sinais de fungo; escrita no anverso; dedicatória: "Ao Mario de Andrade"; local, data e autoria no final do poema: "São Paulo Jan.35 | ARMANDO DE OLIVEIRA"; margem inferior: bilhete de AO para MA em autógrafo a tinta azul: "Mario, esta canção vae | em agradecimento | da carta a respei- | to do Poeminha da | Rosa. | Armando"; fólio numerado pela pesquisa: (1).

Notas da pesquisa:

1. Ms na vertente Mário de Andrade colecionador.

2. Não há cartas de AO no arquivo MA que comprove o envio do ms.

3. De acordo com o bilhete de $\mathrm{AO}$ no ms, o escritor compôs o poema em agradecimento à carta de MA ao livro Poeminha da Rosa (São Paulo, Siqueira, 1934). Há dois exemplares na biblioteca MA, um deles com a dedicatória: "Ao Mario de Andrade, |

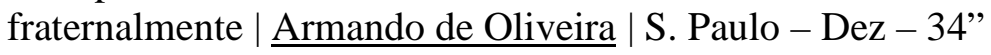

Estudo genético:

1. O ms apresenta-se em uma única versão, A, que mostra 1 etapa na escritura.

MA - MOE, 256

OLIVEIRA, J. Lourenço de

256. Para além do escândalo do professor de gramática; ensaio (MAm)

Belo Horizonte, 15 ago. 1943

Datiloscrito original, fita azul; papel branco, filigrana: "MONROE BOND"; 5 folhas; 31,8 x 21,9 cm; vincos; sinais de fungo; escrita no anverso; f. 1: assinatura a máquina embaixo do título: "J. Lourenço de Oliveira"; f. 5: local e data: "Belo Horizonte, 15.8.1943"; folhas numeradas pelo escritor: 2-5; rasuras a máquina, a lápis e a tinta preta; fólios numerados pela pesquisa: (1)-(5).

Notas da pesquisa:

1. Ms na vertente Mário de Andrade mentor.

2. Na série Correspondência Mário de Andrade, no IEB-USP, não há cartas de JLO a MA.

3. Na biblioteca MA foi guardado apenas um livro de JLO, Tratado de acentuação gráfica ou topologia diacrítica (Belo Horizonte, Imprensa Oficial do Estado, 1943), com a dedicatória: "A Mário de Andrade | com admiração | of Lourenço Oliveira | B. H. 26.9.943". 
Estudo genético:

1. O ms apresenta-se em uma única versão, $A$, que mostra 3 etapas na escritura: $a-a_{1}-a_{2}$ : a: datiloscrito completo;

$\mathrm{a}_{1}$ : rasuras a máquina;

$\mathrm{a}_{2}$ : rasuras a tinta preta.

MA - MOE, 257-259

PACHECO, João (João Almeida Pacheco 1910-1966)

257. O meu cavalo pampa

[São Paulo, ant. 9 março de 1941]

Datiloscrito, cópia carbono preto; papel branco; 11 folhas; 29,1 x 21,4 cm; vinco; sinais de fungo; manchas de carbono; escrita no anverso; folhas numeradas pelo escritor: 2-11; rasuras a máquina e a tinta preta; fólios numerados pela pesquisa: (1)(1) (1).

Nota MA: f. 1: a lápis vermelho na margem superior: "3 contos de João Pacheco".

258. Biografia incompleta de Giuseppe Verdi Mangiamacheronni, maestro de banda

[São Paulo, ant. 9 março de 1941]

Datiloscrito, cópia carbono preto; papel branco; 17 folhas; 29,1 x 21,4 cm; vinco; sinais de fungo; manchas de carbono; furos para arquivamento na margem esquerda; escrita no anverso; folhas numeradas pelo escritor: 2-17; rasuras a máquina e a tinta preta; fólios numerados pela pesquisa: (1)-(1) (7) .

\section{Amador Fonseca - dos Pereira Fonseca, de Pontas}

[São Paulo, ant. 9 março de 1941]

Datiloscrito, cópia carbono preto; papel branco; 25 folhas; 29,1 x 21,4 cm; vinco; manchas de carbono; f. 25: ferrugem de clipe no verso; escrita no anverso; folhas numeradas pelo escritor: 2-25; rasuras a máquina e a tinta preta, em duas tonalidades diferentes; f. 1: rasura a lápis; fólios numerados pela pesquisa: (1)-(2) (5).

Notas da pesquisa:

1. Ms na vertente Mário de Andrade colecionador.

2. Local e data atestados pela carta de JoP a MA, de São Paulo em 9 de março de 1941, que leva o pedido de apresentação a alguma editora dos contos enviados: "[...] ajunto a esta tres contos de uma coleção que tenho e que franca- $\mid$ mente desejaria publicar. Para tanto, porem, não tenho relações | no meio editorial, a que seria inútil levá-la sem uma apresenta- | cão. Tomei, por isso, a liberdade de vir á presença dr Sr., a cu- | já apreciação submeto os contos, assim como a titulo de amostra". (Ref.: série Correspondência Mário de Andrade - sub-série Correspondência passiva; MA-C-CPL, $\left.n^{\circ} 5621\right)$

3. MA apresentou os contos à editora Martins, conforme o que se pode atestar na carta JoP a MA, em 20 de março de 1941: "Endereço-lhes estas linhas para expressar-lhe | meu agradecimento pela atenção que se dignou dispensar-me. [...] Logo que me seja possível, servir-me-ei de sua apresnta- | cão ao sr. Luiz Martins, junto ao qual, aliás, eu 
não tenho | esperança, pois, pelo que li a respeito, a sua publicação | se circusncreverá a ensaios sobre assuntos de atualidade". (Ref.: série Correspondência Mário de Andrade - sub-série Correspondência passiva; MA-C-CPL, $\mathrm{n}^{\circ}$ 5622).

4. Os contos foram publicados em Negra a caminho da cidade (São Paulo, Livraria Martins, 1942).

Estudo genético:

1. O ms apresenta em uma única versão, A.

2. O meu cavalo pampa e Biografia incompleta de Giuseppe Verdi Mangiamacheronni, maestro de banda mostram 3 prováveis etapas na escritura: $\mathrm{a}-\mathrm{a}_{1}-\mathrm{a}_{2}$ :

a: datiloscrito completo;

$\mathrm{a}_{1}$ : rasuras a máquina;

$\mathrm{a}_{2}$ : rasuras a tinta preta.

3. Amador Fonseca - dos Pereira Fonseca, de Pontas mostra 5 etapas na escritura: a-a a $^{-}$ $\mathrm{a}_{2}-\mathrm{a}_{3}-\mathrm{a}_{4}$ :

a: datiloscrito completo

$\mathrm{a}_{1}$ : rasuras a máquina

$\mathrm{a}_{2}, \mathrm{a}_{3}, \mathrm{a}_{4}$ : rasura a lápis e rasuras a tinta preta, nas duas tonalidades.

4. Provavelmente os ms são os mesmos entregues à editora Martins, pois no confronto entre as versões A e B, em Negra a Caminho da cidade.

MA - MOE, 260

PACHECO, João (João Almeida Pacheco 1910-1966)

260. Mario de Andrade poeta; ensaio (MAc)

[São Paulo, post. 10 ago. 1942]

Datiloscrito original, fita preta; papel branco, filigrana: "VICTORIA | INDUST. BRASIL."; 5 folhas; 26,2 x 20,9 cm; vinco; sinais de fungo; f. 2-3: mancha de tinta com marca de digital; escrita no anverso; f. 5: assinatura a máquina: "João Pacheco" e assinatura a tinta preta: "João Pacheco"; folhas numeradas pelo escritor: 2-5; rasuras a máquina e a tinta preta; fólios numerados pela pesquisa: (1)-(5).

Notas da pesquisa:

1. Ms na vertente Mário de Andrade colecionador.

2. Junto da carta a MA, de São Paulo em 10 de agosto de 1942, JoP encaminhou o ms, nela escreve: "Junto também segue um pequeno artigo - | que destinava á publicação na 'Gazeta Ma- |gazine' e em que tento sintetizar as minhas | impressões sobre o seu livro 'Poesias', recentemente | publicado [...]'.(Ref.: série Correspondência Mário de Andrade - sub-série Correspondência passiva; MA-C-CPL, ${ }^{\circ}$ 5623)

3. Em [1970] JoP publicou Poesia e prosa de Mário de Andrade pela Martins Editora. 
Estudo genético:

1. O ms apresenta-se em uma única versão, $A$, que mostra 3 etapas na escritura: $a-a_{1}-a_{2}$ : a: datiloscrito completo;

$\mathrm{a}_{1}$ : rasuras a máquina;

$\mathrm{a}_{2}$ : rasuras a tinta preta.

MA - MOE, 261

PATERNOSTRO, Júlio

261. Chacara; poesia (MAc)

[Rio de Janeiro], s/ data

Autógrafo a tinta preta; papel branco, filigrana; 1 folha; $22,0 \times 14,3 / 14,5 \mathrm{~cm}$; borda direita cortada; vincos; sinais de fungo; escrita no anverso; dedicatória: embaixo do título: "(Pro Mario de Andrade)"; assinatura a tinta preta no final do poema: "Julio Paternostro"; fólio numerado pela pesquisa: (1).

Notas da pesquisa:

1. Ms na vertente Mário de Andrade colecionador.

2. Há um livro de JuP na biblioteca MA: Olha o café! Poemas assim assim (São Paulo, Casa Duprat-Mayença, 1928), com notas MA a lápis preto e a dedicatória: "Ao Mario de Andrade (eu queria | dizer uma porção de coisas perto | desse nome, mas não digo nada | porque eu me estrepo) | offerece o | Julio Paternostro | S. Paulo, Jun. 928”.

3. Chacara não está publicado em Olha o café! Poemas assim assim (ed. cit.).

Estudo genético:

1. O ms apresenta-se em uma única versão, A, que mostra 1 etapa na escritura.

MA - MOE, 262

PAURILIO, Carlos (Carlos Malheiros da Silva 1904-1941)

262. Abandono; A estrela; A floresta; As canôas; Casa abandonada; Chuva; Cordeirinho; Elegia a uma passageira do Aratimbó; Eu tenho um ar de velho retrato; Jogo infantil; Mãos postas; Marinheiro morto; Muro de cemiterio; Na noite; Nevoa e silencio; $O$ adeus; O cégo; Os anjos; Praia do Sobral; Repouso; Simbad; Sombra do meu pai; Sumidouro; Ternura; Urbano; poesia (MAm)

[Maceió], s/ data

Datiloscrito original, fita preta; papel branco; 26 folhas; 28,0 x 21,6 cm, f. 1: 27,9 x $21,5 \mathrm{~cm}$; vincos; sinais de fungo; 2 furos e ferrugem de grampo na margem esquerda; f. 1: irregularidades nas bordas e rasgamento na borda inferior à direita; f. 6: rasgamento em 1 dos furos; f. 7: irregularidades nas bordas superior e direita e 2 furos pequenos: embaixo do v. 6 e no canto inferior direito; f. 7, 24: rasgamentos nos furos de grampo; f. 11: irregularidades nas bordas direita e inferior; f. 13, 23: 
irregularidades na borda superior; f. 24: irregularidades nas bordas superior, direita e inferior e manchas de acidez; escrita no anverso; f. 1: capa com autoria e título: "Carlos PAURILIO | Poemas"; rasuras a máquina e a lápis preto; fólios numerados pela pesquisa: (1)-(2) (6).

Notas da pesquisa:

1. Ms na vertente Mário de Andrade mentor.

2. Carlos Paurilio era o pseudônimo de Carlos Malheiros da Silva.

3. CP tem um livro de poesia publicado, Reflexos e natura, mas não foi possível localizálo.

4. Na série Correspondência Mário de Andrade não há carta de CP.

Estudo genético:

1. O ms apresenta-se em uma única versão, A.

2. Abandono, A estrela, A floresta, Eu tenho um ar de velho retrato, Jogo infantil, Marinheiro morto, Muro de cemiterio, Na noite, Praia do Sobral, Repouso, Sumidouro, Ternura mostram 1 etapa na escritura.

3. As canôas, Casa abandonada, Chuva, Mãos postas, Nevoa e silencio, O cégo, Os anjos, Simbad, Urbano mostram 2 etapas na escritura: a-a $a_{1}$ :

a: datiloscrito completo;

$\mathrm{a}_{1}$ : rasuras a máquina.

4. Cordeirinho, Sombra do meu pai mostram 2 etapas na escritura: a-a $a_{1}$ :

a: datiloscrito completo;

$\mathrm{a}_{1}$ : rasuras a lápis preto.

5. Elegia a uma passageira do Aratimbó, $O$ adeus mostram 3 etapas na escritura: $\mathrm{a}_{-} \mathrm{a}_{1}-\mathrm{a}_{2}$ :

a: datiloscrito completo;

$\mathrm{a}_{1}$ : rasuras a máquina;

$\mathrm{a}_{2}$ : rasuras a lápis.

MA - MOE, 263

PEIXOTO, Francisco Inácio (1909-1985)

263. Ciume; poesia (MAm)

[Cataguases, ant. 18 mar. 1927]

Datiloscrito, cópia carbono roxo; 1 folha; 13,9/14,1 x 16,4/16,5 cm; borda direita cortada; borda inferior recortada com tesoura; vinco; sinais de fungo; manchas de carbono; letras manchadas; escrita no anverso; assinatura a tinta preta no final do poema: "Francisco Ignacio Peixoto"; rasura a máquina; fólio numerado pela pesquisa: (1).

Nota MA a lápis preto no verso: "Francisco Inacio Peixoto".

Anexo:

Envelope branco; 12,4 x 15,5 cm; sinais de fungo; fólio numerado pela pesquisa: (1). Nota MA a lápis preto: "Francisco Inacio Peixoto". 
Notas da pesquisa:

1. Ms na vertente Mário de Andrade mentor.

2. Data atestada com base na carta de FIP a MA, de Cataguases em 18 de março de 1927, na qual se lê: "No ciume que eu mandei já havia notado | aquela falta de ritmo que você falou. Até | antes de tudo tinha dito ao Fusco" "Segue Maria Lavadeira. Poeminha feito | hontem. Naturalmente ainda vou reformar | o bicho. Mas vai assim mesmo. Pra gente | de casa não precisa muito luxo". (Ref.: série Correspondência Mário de Andrade - subsérie Correspondência passiva; MA-C-CPL, $\mathrm{n}^{\circ}$ 5656)

3. Poemas publicados em Meia-pataca (Cataguazes, Verde Editora, 1928)

\section{Estudo genético:}

1. O ms apresenta-se em uma única versão, A, que mostra 2 etapas na escritura: a-a : $_{1}$ a: datiloscrito completo; $\mathrm{a}_{1}$ : rasuras a máquina.

2. Versão A confrontada coma versão B, em Meia-pataca (ed. cit.), apresenta poucas variantes.

\section{MA - MOE, 264}

PEIXOTO, Francisco Inácio (1909-1985)

264. Maria lavadeira; poesia (MAm)

Cataguases, [18 mar. 1927]

Datiloscrito original, fita vermelha; papel branco, filigrana, borda superior picotada; 1 folha; 26,2 x 21,5 cm; vincos; sinais de fungo; manchas de carbono roxo; letras manchadas; escrita no anverso; assinatura e local embaixo do poema: "Francisco I. Peixoto | Ctaguazes.”; rasura a máquina; fólio numerado pela pesquisa: (2).

Notas da pesquisa:

1. Ms na vertente Mário de Andrade mentor.

2. Data atestada com base na carta de FIP a MA, de Cataguases em 18 de março de 1927, na qual se lê: "No ciume que eu mandei já havia notado | aquela falta de ritmo que você falou. Até | antes de tudo tinha dito ao Fusco" "Segue Maria Lavadeira. Poeminha feito | hontem. Naturalmente ainda vou reformar | o bicho. Mas vai assim mesmo. Pra gente | de casa não precisa muito luxo". (Ref.: série Correspondência Mário de Andrade - subsérie Correspondência passiva; MA-C-CPL, $\mathrm{n}^{\circ}$ 5656)

3. Poemas publicados em Meia-pataca (Cataguazes, Verde Editora, 1928)

Estudo genético:

1. O ms apresenta-se em uma única versão, A, que mostra 2 etapas na escritura: a-a $a_{1}$ : a: datiloscrito completo; $\mathrm{a}_{1}$ : rasuras a máquina.

2. Versão A confrontada coma versão B, em Meia-pataca (ed. cit.), exibe poucas variantes. 
MA-MOE, 265

PELEGRINO, Hélio (1924-1987)

265. Madrugada; poesia (MAm)

[Belo Horizonte, ant. set. 1944]

Datiloscrito original, fita preta; papel branco, timbrado: "SERVIÇO PÚBLICO DO ESTADO DE MINAS GERAIS"; 1 folha; 31,5 x 21,6/21,7 cm; vincos; sinais de fungo; 2 furos para arquivamento; escrita no anverso; autoria embaixo do título: "Helio Pelegrino"; rasura a máquina; fólio numerado pela pesquisa: (1). Nota HP a tinta azul no final do poema: "Mario, | eu gosto muito desse | poema. Você o que | acha?".

Notas da pesquisa:

1. Ms na vertente Mário de Andrade mentor.

2. Local e data atestados com base na data da segunda versão de Madrugada enviada a MA em [setembro de 1944] (V. MA-MOE, 266).

3. O poema está publicado na edição póstuma Minérios domados (Seleção e edição de Humberto Werneck, Rio de Janeiro, Rocco, 1993). Na apresentação, o organizador explica: "Entre os papéis de Hélio Pellegrino a família encontrou considerável quantidade de originais, manuscritos ou datiloscritos, recolhidos hoje aos arquivos da Fundação Casa de Ruy Barbosa, do Ministério da Cultura, no Rio de Janeiro. Com base nesse material, mais o que as circunstâncias permitiram garimpar em outras fontes (alguma coisa mais haverá, talvez, espalhada em jornais e revistas dos anos 40 a 80) é que se organizou este livro, [...]". Provavelmente os ms guardados por MA não foram consultados, pois ficaram alguns inéditos.

Estudo genético:

1. HP enviou 2 versões de Madrugada a MA. A acima registrada foi a primeira, e considerada pela pesquisa versão A.

2. A versão A de madrugada mostra 2 etapas na escritura: $\mathrm{a}-\mathrm{a}_{1}$ :

a: datiloscrito completo;

$\mathrm{a}_{1}$ : rasura a máquina.

3. Foram confrontadas as versões A e B nos ms e a versão C em Minérios domados (ed. Cit.). Há poucas variantes entre as 3 vesões.

\section{MA-MOE, 266}

PELEGRINO, Hélio (1924-1987)

266. Aurora sem sangue; $O$ amigo da morte; Canção e esperança; Fala de "Maquis"; Fragmento; Hora de exílio; Liberdade; Madrugada; Poema para o amigo; Porque, senhor?; Necessidade de ser inutil; Poema ["Esse olhar fixo atravessando o tempo"]; Poema ["Quando se consumar a minha traição e a dos outros;"]; Poema ["Que posso fazer agora"]; Poema ["Senhor, o mundo me absorve."]; Poema do principe exilado; Pranto para Fernando Sabino; Soneto; A espera imovel; Canção dos sete apartamentos; Deixai-o; Poema ["Amigos, não há amigos"]; Poema ["Há um 
desespero qualquer, uma chama, um apelo obscuro"]; Poema ["Irás longe, muito longe."]; Poema e morte; Poema na parede; poesia (MAm)

[Belo Horizonte, set. 1944]

Datiloscrito, cópia carbono preto; papel branco tipo seda, f. 1: capa improvisada em pasta recortada; papel verde, impresso: "Classificador rapido Estante ou divisão No.

| Principiado em: | Terminado em:", carimbo: "Prefeitura Municipal de Passos"; 31 folhas; f. 1: 31,1/31,5 x 20,3/20,9 cm, f. 2-31: 27,0 x 19,9 cm, com variações em mm na largura; sinais de fungo; f. 1: bordas superior, esquerda e inferior recortadas, sinais de amassado, mancha de tinta azul e pequenas manchas de tinta preta; f. 6-8, 14, 16, 20-21, 23-24, 30-31: irregularidades na borda inferior; f. 9: irregularidades na borda superior e vinco diagonal na margem esquerda; f. 10: canto inferior esquerdo rasgado, manchas de carbono e letras dos v. 34-35 borradas; f. 11: manchas de carbono; f. 12: manchas de tinta preta; f. 13, 17, 19, 22, 26-29: irregularidades na borda superior; $f$. 14: pequeno furo na altura do título; f. 15: pequenos furos na margem inferior à esquerda; f. 24-25: borda inferior rasgada à direita; escrita no anverso; f. 7, 19, 21 numeradas pelo escritor; rasuras a máquina e a tinta preta; fólios numerados pela pesquisa: (1)-(2) (2). Nota HL a tinta preta: f. 1: margem inferior: ilegível. Notas Terceiro: a tinta azul: "É FAVOR NÃO | PEDIR PARA | VER. SE EU DISSER | O CONTRARIO É| GENTILEZA APENAS”. Notas MA.

Capa:

Nota MA a lápis vermelho: indicação de autoria: "Helio Pelegrino".

Poema do principe exilado:

Dedicatória embaixo do título: "Para Mário de Andrade"; data no final do poema: "Setembro, 1944".

Notas da pesquisa:

1. Ms na vertente Mário de Andrade mentor.

2. Data atestada com base na carta de HP a MA, de Belo Horizonte em setembro de 1944, em que escreve: "Este poema, que escrevi | ontem, quero dedicá-lo | a você. E mesmo para | você ler" [referindo-se a Poema do principe exilado]. (Ref.: série Correspondência Mário de Andrade - sub-série Correspondência passiva; MA-C-CPL, $n^{\circ}$ 5686). Nessa missiva não há menção a outros poemas, porém o conjunto de ms deve ter sido encaminhado nessa ocasião em virtude das informações nas duas cartas posteriores de HP a MA: em 15 de outubro de 1944, relata: "Embora na sua carta você me diz que certas | aventuras minhas são prematuras e mesmo imbecis, | te dou a mais completa razão, Mário, a mais comple- | ta razão.", provavelmente referindo-se a comentários de MA sobre os poemas no ms; em carta de 2 de novembro de 1944, escrita em conjunto com Otto Lara Resende em dois cartões de visita deste, pede a devolução de seus ms e fala de Soneto no ms: "Mário, quero te pedir um grande fa- | vor. Quero que você me mande os ver- $\mid$ sos que estão com você. Pois não tenho | outra cópia, os originais estão com um | amigo. Concordo com | as modificações que você sugere nos | poemas Madrugada, nos versos finais, | 'Velho dicionário, palavras extintas'. E | com o soneto dá-se o mesmo, forte e leve' é mesmo muito melhor." (Ref.: série Correspondência Mário de Andrade - sub-série Correspondência passiva; MA-C-CPL, $\mathrm{n}^{\circ} 5687$ e MA-C-CPL, n 5688). 
3. HP enviou uma versão anterior de Madrugada (V. MA-MOE, 265).

4. Há 4 poemas homônimos com o título Poema.

5. Aurora sem sangue, $O$ amigo da morte, Madrugada, Poema ["Esse olhar fixo atravessando o tempo"], Poema ["Quando se consumar a minha traição e a dos outros;"], Poema [“Senhor, o mundo me absorve."], Poema do principe exilado e Canção dos sete apartamentos foram publicados na edição póstuma Minérios domados (ed.cit.) (V. MA-MOE, 265, nota 3).

\section{Estudo genético:}

1. Madrugada apresenta-se em versão B. Os demais poemas mostram-se em uma única versão, A (Versão A de Madrugada em MA-MOE, 265).

2. A espera imovel e Poema e morte mostram 1 etapa na escritura.

3. Aurora sem sangue, $O$ amigo da morte, Canção e esperança, Hora de exílio, Porque, senhor?, Necessidade de ser inutil, Poema ["Esse olhar fixo atravessando o tempo"], Poema ["Quando se consumar a minha traição e a dos outros,"], Poema ["Senhor, o mundo me absorve."], Poema do principe exilado, Pranto para Fernando Sabino, Soneto, Canção dos sete apartamentos, Deixai-o, Poema [“Amigos, não há amigos”], Poema ["Há um desespero qualquer, uma chama, um apelo obscuro"], Poema ["Irás longe, muito longe."] e Poema na parede mostram 2 etapas na escritura: a-a ${ }_{1}$ : a: datiloscrito completo; $\mathrm{a}_{1}$ : rasuras a máquina.

4. Fragmento mostra 2 etapas na escritura: $\mathrm{a}-\mathrm{a}_{1}$ : a: datiloscrito completo; $\mathrm{a}_{1}$ : rasuras a máquina.

5. Fala de "Maquis", Fala de "Maquis", Poema para o amigo, Poema ["Que posso fazer agora"] e Poema do principe exilado mostram 3 etapas na escritura: a-a ${ }_{1}-\mathrm{a}_{2}$ :

a: datiloscrito completo;

$\mathrm{a}_{1}$ : rasuras a máquina; $\mathrm{a}_{2}$ : rasuras a tinta preta.

6. A versão B, do poema Madrugada mostra 3 etapas na escritura: $\mathrm{b}-\mathrm{b}_{1}-\mathrm{b}_{2}$ :

b: datiloscrito completo;

$\mathrm{b}_{1}$ : rasuras a máquina;

$\mathrm{b}_{2}$ : rasuras a tinta preta.

7. Versão A confrontada com a versão B em Minérios domados (ed. cit.). Aurora sem sangue, Amigo da morte, Poema ["Esse olhar fixo atravessando o tempo"], Poema ["Quando se consumar a minha traição e a dos outros;"], Canção dos sete apartamentos não apresentam variantes entre ambas versões. Poema ["Senhor, o mundo me absorve."] apresenta uma variante na pontuação. Poema do principe exilado apresenta poucas variantes. 
MA-MOE, 267

PINTO, Lauro

267. O São Paulo de meu gorro; poesia (MAm)

Assú, 29 mar. 1938

Datiloscrito original; papel branco, filigrana; 1 folha; 32,8 x 21,6 cm; vincos; sinais de fungo; escrita no anverso e no verso; dedicatória acima do título: "PARA MARIO DE ANDRADE"; local, data e assinatura a tinta preta no final do poema: "Assú, 29 de março de 1938. | Lauro Pinto.”; fólio numerado pela pesquisa: (1).

Notas da pesquisa:

1. Ms na vertente Mário de Andrade mentor.

2. LP enviou o ms provavelmente junto da carta a MA, de Assú em 29 março de 1938, na qual escreve: "Hontem, eu nada tendo que fazer e, para | não estragar totalmente o meu tempo resolvi fazer | o quebra cabeça anexo para você. Estraguei sem- | pre o meu tempo... Leia a xaropada e depois va com | ella a cesta. É um favor que você me faz. Escreva.”. (Ref.: série Correspondência Mário de Andrade - sub-série Correspondência passiva; MA-C-CPL, $\mathrm{n}^{\circ}$ 5840).

3. O poema permaneceu inédito.

Estudo genético:

1. O ms apresenta-se em uma única versão, A, que mostra 1 etapa na escrita.

MA-MOE, 268

QUEIROZ, Raquel de (1910-2004)

268. João Miguel; romance (MAc)

[Itabuna], set. - 7 nov.1931

Autógrafo a tinta preta e a lápis preto; papel branco, pautado: f. 3-10; 86 folhas; f. 1, 53-65: $32,6 / 32,7$ x 22,1, f. 2 , 11-52: 26,6 × 22,0 cm, f. 3-10: 33,0 x 22,3 cm, com variações em mm, f. $66-84: 32,8$ x 18,9 cm; f. 1: pequenos rasgamentos nas bordas e sinais de amassado; f. 3-10: bordas danificadas com sinais de amassado e rasgamentos; f. 66-84: bordas inferior e superior danificadas com sinais de amassado e rasgamentos; pequenos rasgamentos nas bordas; sinais de fungo; manchas de tinta; escrita no anverso e no verso; f. 1: capa em autógrafo a tinta preta com título, autoria e data: "João Miguel | Chronica dum penitenciario | Raquel de Queiros - Setembro 1931."; f. 6: data no canto superior direito: "21-1-31"; páginas numeradas pela escritora; desenhos; rasuras a tinta preta, a tinta verde, a lápis preto, a lápis azul e vermelho; fólios numerados pela pesquisa: (1)-(8) (6). Notas RQ: contas; f. 1: no verso: anotação sobre o romance no ms; f. 2: no verso: poema: "Meu coração era espelho | Que a todos pintava, engrato! | Mas chegou você, mirou-se | E o espelho virou retrato..."; f. 3: "Sempre que se começa um livro, começa- | se uma carreira literária. E cada livro que | se lança tem-se as andecisões e a incer- | titude de uma estréa. O sucesso obti- $\mid$ do antes de animar desanima. Deixa-nos o | assombrado receio da 
entermittencia e da | irregularidade inspiração. Eu acredito na inspiração, senhora e | soberana como acredita qualquer poeta romantico."; f. 14: "No dia em que se descobre o motu-continuo, desaparece o prestigio de Deus..."; f. 56: "O morrer pertence a Deus!".

\section{Anexo:}

Capa improvisada por MA em pedaço da capa de pasta cor de rosa; 1 folha; 28,9/29,1 x 22,9/23,1 cm; bordas esquerda, direita e inferior recortadas; sinais de amassado; impresso colado no canto superior direito do verso: "PAULO BASILIO | Industria Brasileira | 100 réis", canto superior esquerdo: carimbo: "CASA BRUNO"; fólio numerado pela pesquisa: (1).

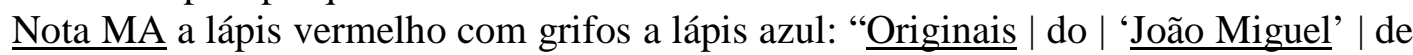
| Raquel de Queiroz".

\section{Notas da pesquisa:}

1. Ms na vertente Mário de Andrade colecionador.

2. João Miguel (Rio de Janeiro, Schmidt) foi publicado em 1932. MA guardou 2 exemplares em sua biblioteca, um deles com a dedicatória: "Ao Mario | de Andrade |o grande Mário - | toda a admiração | de | Rachel”.

\section{Estudo genético:}

1. Ms encontra-se em uma única versão, A, que mostra 7 prováveis etapas na escritura: a$a_{1}-a_{2}-a_{3}-a_{4}-a_{5}-a_{6}$ :

a: autógrafo a tinta preta;

$\mathrm{a}_{1}$ : autógrafo a lápis preto;

$a_{2}-a_{3}-a_{4}-a_{5}-a_{6}$ : rasuras a tinta preta, a tinta verde, a lápis preto, a lápis azul e a lápis vermelho.

\section{MA-MOE, 269}

\section{QUEIROZ, Raquel de (1910-2004)}

269. As três Marias; romance (MAc)

Rio de Janeiro, 19 fev. 1937

Caderno + folhas soltas:

Caderno: autógrafo a lápis preto; capa dura, cor de vinho; 27,6 × 21,3 cm; lombada destruída com perda de revestimento; quarta-capa, f. 63 e as 3 últimas folhas desprendidas do caderno; guarda em papel azul; bordas da capa desgastadas; miolo: papel branco, paltado; 27,6 x 21,3 cm; 98 folhas; f. 63: rasgamentos na borda superior; escrita no anverso e no verso; título e autoria: f. 1: "As três Marias |19/2/37; dedicatórias: no verso da guarda: "Para Mario de | Andrade, | as três Marias agra- | decidas, com um grande | abraço de Rachel | Rio, $1^{\circ}$ junho 1940", f. 1: "Este livro é dedicado ao I poeta Manoel Bandeira"; páginas numeradas pela escritora; rasuras a lápis preto e a lápis tinta; desenhos da escritora: no anverso: f. 76, 98, 99; no verso: f. 25, 40, 41, 75; desenho de João Mateus: f. 1; fólios numerados pela pesquisa: (1)(1) (1) (2). 
Notas MA: a lápis azul, vermelho e preto: marcações e rubricas; f. 11 no anverso e no verso, f. 12 no anverso: riscos verticais a lápis vermelho ocupando toda a folha; f. 98: a lápis preto: "(Estes desenhos foram feitos | pela romancista M de A.)"; f. 1: a lápis preto: indicando autoria do desenho: "(Desenho de João Mateus. M de A)

Folhas soltas: autógrafo a lápis preto e a lápis tinta; papel branco, pautado: f. 1-2; 21,7 x 13,3 cm: f. 1-2, 29,9 x 21,4 cm; 12 folhas; f. 1, 6: vinco diagonal; sinais de fungo; $\mathrm{f}$. 2 amassada na parte direita; f. 3-12: rasgamentos na margem esquerda; f. 3: tira de papel colado no verso; escrita no anverso e no verso; rasuras a lápis preto e a lápis tinta; fólios numerados pela pesquisa: (1) (1) (3)-(1) (1) (4).

\section{Notas da pesquisa:}

1. Ms na vertente Mário de Andrade colecionador.

2. Três Marias (Rio de Janeiro, José Olympio) foi publicado em 1939. MA guardou dois exemplares do livro em sua biblioteca, um deles com a dedicatória: "Para o | Mario de Andrade | este livrinho, com um | grande abraço | Rachel | 23/8/39".

\section{Estudo genético:}

1. Noa arquivo MA o ms apresenta-se em uma única versão, A, que mostra 3 etapas na escritura: $a-a_{1}-a_{2}-a_{3}$ :

a: autógrafo a lápis preto;

$\mathrm{a}_{1}-\mathrm{a}_{2}$ : rasuras a lápis preto e a lápis tinta

\section{MA-MOE, 270}

RAMOS, Alberto (Alberto Ferreira Ramos 1871-1941)

270. Poemas do "O ultimo canto do fauno"; poesia (MAc)

[São Paulo, post. 11 maio 1928]

Apógrafo de Maria de Lourdes Moraes Andrade; datiloscrito original, fita azul; papel beje, tipo jornal; 12 folhas; 29,0/29,4 x 23,3 cm, com variação em mm na largura; bordas laterais cortadas; vincos; sinais de fungo; f. 1: rasgamentos nas bordas e ferrugem de grampo na margem inferior à direita; f. 2-3, 6, 8-9, 11: rasgamentos na borda direita; margem superior esquerda: furo de grampo com sinal de ferrugem e rasgamento no furo; escrita no anverso; f. 1: autoria, local e data: "Alberto Ramos | Rio de Janeiro 1913"; folhas numeradas pelo escritor: 2-12; rasuras a máquina; fólios numerados pela pesquisa: (1)-(1) (2).

O conjunto de ms apresenta o títulos: $O$ ultimo canto do fauno, Prometheu acorrentado, Ad solem e Outono e Inscripção.

Notas da pesquisa:

1. Ms navertente Mário de Andrade colecionador.

2. Os poemas foram copiados pela irmã de MA do livro Último canto do fauno, de Alberto Ramos (1913). Maria de Lourdes, quando solteira, costumava ajudar o irmão na organização da biblioteca, além de copiar cartas e ms. 
3. Data, local e apógrafo atestados com base na carta de MA a Manuel Bandeira, de São Paulo em 11 de maio de 1928: "Recebi o Alberto Ramos. Já as coisas que gostei pedi pra mana copiar. Copiadas o livro seguirá". MA havia encaminhado a MB uma lista com títulos de AlR que lhe interessavam. Atendendo ao seu pedido, MB enviou-lhe Último canto do fauno junto da carta de 5 de maio de 1928, na qual escreve: "Hoje quero mandar-lhe apenas algumas linhas acompanhando o Último canto do fauno do Alberto Ramos, exemplar que depois de muita procura, consegui descobrir para the emprestar. Leia-o e devolva-o logo que puder, pois o dono, embora meu tio e padrinho, é pessoa com quem não gosto de facilitar" (Correspondência Mário de Andrade \& Manuel Bandeira. Ed. cit., p.387-388).

Estudo genético:

1. O ms apresenta-se em uma única versão, $A$, que mostra 2 etapas dna escritura: $a-a_{1}$ : a: datiloscrito completo;

$\mathrm{a}_{1}$ : rasuras a máquina

\section{MA-MOE, 271}

RANGEL, Luiz Felipe do Rego

271. Um capricho mystico de grandes planos; conto (MAc)

Marseille, 15 abr. 1927

Autógrafo a tinta preta; papel branco, pautado; 2 folhas; f. 1: 30,2 x $19,7 \mathrm{~cm}$, f. 2 : $30,2 \times 19,8 / 19,9 \mathrm{~cm}$; borda esquerda cortada; vincos; sinais de amassado; sinais de fungo; f. 2: rasgamentos nas bordas esquerda e direita; f. 1: escrita anverso e no verso, f. 2: escrita no anverso; f. 1: dedicatória: "Ao Mario de Andrade | espirito curioso e original, | prenhe de subtilezas | metaphisicas inesperadas.”; f. 2: local, data e autoria: "Marseille le 15 Avril 1927. Luiz Felippe Rangel"; rasuras a tinta preta e a tinta verde; f. 1: recorte colado no canto superior esquerdo: papel tipo cartolina, cor de laranja, com texto impresso cortado: "Le", 0,1/6,0 x 0,3/7,9 cm, Nota LFR a tinta preta: "Variações."; fólios numerados pela pesquisa: (1)-(2).

Anexo:

Bilhete de LFR a MA; datado: "Marseille 29 maio de 1927."; forma de tratamento: "Ao Mário"; autógrafo a tinta preta; em cartão de visita com impresso anulado pela rasura a tinta preta, com exceção do nome "RANGEL", aproveitado como assinatura: "L. F. do Rege Rangel/ Vice Consul du Brésil"; 5,7 x 9,6 cm; escrita no anverso; fólio numerado pela pesquisa: (3). Conteúdo: "Ao Mário, pedindo-lhe revistas de São Paulo | em tróca das daqui e Hespanha, o que | hoje tem um espirito secco de empregado | sem ideal; apezar de viver num centro traba- | lhado em cultura platonica e mais ou menos | academica".

(Ref. cruzada: Série Correspondência Mário de Andrade; sub-série Correspondência passiva: MA-C-CPMVA, $\mathrm{n}^{\circ}$ 6074) 
Notas da pesquisa:

1. Ms na vertente Mário de Andrade colecionador.

2. Não consta que o conto tenha sido publicado.

Estudo genético:

1. O ms apresenta-se em uma única versão, A, que mostra 3 prováveis etapas na escritura: $\mathrm{a}-\mathrm{a}_{1}-\mathrm{a}_{2}$ :

a: autógrafo completo;

$\mathrm{a}_{1}-\mathrm{a}_{2}$ : rasuras a tinta preta e rasura a tinta verde..

\section{MA-MOE, 272}

\section{RANGEL, Luiz Felipe do Rego}

272. Eschemas preciosistas (Malabarismos); pensamentos (MAc)

S/ local, s/ data

Autógrafo a tinta vermelha, título: autógrafo a tinta vermelha e preta; papel branco; 5 folhas; 22,2 x $12,5 \mathrm{~cm}$, com variação em mm na largura; irregularidades na borda direita; vincos; sinais de fungo; letras borradas; escrita no anverso e no verso; f. 5: assinatura a tinta vermelha no verso: "Luiz Felippe do Rego Rangel"; rasuras a tinta preta e vermelha; fólios numerados pela pesquisa: (1)-(5). Nota LFR em autógrafo a tinta preta embaixo da assinatura: " $<<\ldots$ espero-o no Pombo, em compa- $\mid$-nhia dos meus amigos Li e admirei $\mid$ <suas bellas astronomias〉> Ramón Gómes de la | Serna".

Notas da pesquisa:

1. Ms na vertente Mário de Andrade colecionador.

2. Ramón Gómes de la Serna traduziu textos de C. G. Jung e Karl Jaspers.

Estudo genético:

1. O ms apresenta-se em uma única versão, A, que mostra 3 prováveis etapas na escritura: $\mathrm{a}-\mathrm{a}_{1}-\mathrm{a}_{2}$ :

a: autógrafo completo;

$\mathrm{a}_{1}, \mathrm{a}_{2}$ : rasuras a tinta preta e rasura a tinta verde.

\section{MA-MOE, 273}

REBELO, Marques (Eddy Dias da Cruz 1907-1973)

273. Rua Alegre $n^{\circ}$ 12; teatro (MAm)

[Rio de Janeiro, ant. 1940]

Datiloscrito original, fita vermelha e fita preta; papel branco; 68 folhas; 25,7 x 20,2 $\mathrm{cm}$; f. 54, 69: rasgamento na borda superior à esquerda; sinais de fungo; marca de clipe na borda superior à esquerda; f. 2, 31-32, 53-54, 69: ferrugem de clipe no verso; escrita no anverso; folhas numeradas pelo escritor: 1-11, 11A-67; f. 68: assinatura a 
lápis preto: "Marques Rebêlo"; rasuras a máquina em fita vermelha e preta, a lápis preto e a tinta preta; fólios numerados pela pesquisa: (2)-(6) (9). Nota MaR a lápis preto: f. 2 na margem superior: " 1 a versão".

Ms acondicionado em pasta cinza; 28,1 x 22,3 cm; lombada: 2,3 cm de largura; rasgamentos nas bordas e na lombada; manchas de tinta preta no verso da quartacapa; fólios numerados pela pesquisa: (1)-(7) (0). Notas MaR a lápis preto: capa: título e assinatura e contas: "RUA | ALEGRE | N $12 \mid$ Marques Rebelo", anverso e verso da capa e verso da quarta-capa: números. Notas a lápis: quarta-capa: "Elza $=485762$ | Rebello = 484752 | Telephone do Marques | 12 - [?] - 14".

Notas da pesquisa:

1. Ms na vertente Mário de Andrade mentor.

2. Data atestada com base na publicação da peça Rua Alegre, 12. Local atestado pelo fato de MaR morar no Rio de Janeiro.

3. Em 1940 foi publicada Rua Alegre, 12 (Curitiba, Guaíra). Há dois exemplares na biblioteca MA, um deles com a dedicatória: "Ao | Mário | oRebêlo | Nata 940".

4. Na série correspondência Mário de Andrade, no IEB-USP, não há carta de MaR que comprove o envio do ms.

5. MA conservou em seu arquivo 3 versões de Rua Alegre, 12 (V. MA-MOE, 274 e MAMOE, 275).

Estudo genético:

1. Rua Alegre, 12 apresenta-se em 3 versões. A acima registrada foi considerada A pela pesquisa (V. análises documentárias das versões B e C: MA-MOE, 274 e MA-MOE, 275). Há variantes entre essas três versões.

2. A versão A mostra 6 etapas na escritura: $a-a_{1}-a_{2}-a_{3}-a_{4}-a_{5}$ : a-a $a_{1}$ : datiloscrito completo em fita vermelha e preta alternadamente; $\mathrm{a}_{2}-\mathrm{a}_{3}$ : rasuras a máquina, em fita vermelha e preta; $\mathrm{a}_{4}-\mathrm{a}_{5}$ : rasuras a lápis e a tinta preta.

3. Versão A confrontada com a versão D, Rua Alegre, 12 (ed. cit.), exibe variantes.

\section{MA-MOE, 274}

REBELO, Marques (Eddy Dias da Cruz 1907-1973)

274. Rua Alegre $n^{\circ} 12$; teatro (MAm)

[Rio de Janeiro, ant. 1940]

Datiloscrito original, fita preta; papel branco; 34 folhas; 25,4 x $20,1 \mathrm{~cm}$; f. 1 : rasgamentos na borda direita; vinco; sinais de fungo; sinal de clipe na borda superior à esquerda; f. 1, 34: marca de ferrugem de clipe na borda superior à esquerda; f. 1-25, 27-28, 30-34: escrita no anverso, f. 26, 29: escrita no anverso e no verso; f. 34: assinatura a lápis preto: "Marques Rebêlo"; folhas numeradas pelo escritor: 1-34; rasuras a máquina, a lápis e a tinta preta; fólios numerados pela pesquisa: (1)-(3) (4). 
Notas da pesquisa:

1. Ms na vertente Mário de Andrade mentor.

2. Data atestada com base na publicação da peça Rua Alegre, 12. Local atestado pelo fato de MaR morar no Rio de Janeiro.

3. Em 1940 foi publicada Rua Alegre, 12 (Curitiba, Guaíra) (V. MA-MOE, 273, nota 3).

4. Na série correspondência Mário de Andrade, no IEB-USP, não há carta de MaR que comprove o envio do ms.

5. MA conservou em seu arquivo 3 versões de Rua Alegre, 12 (V. MA-MOE, 273 e MAMOE, 275).

Estudo genético:

1. Rua Alegre, 12 apresenta-se em 3 versões. (V. análises documentárias das versões A e C: MA-MOE, 273 e MA-MOE, 275). Há variantes entre essas três versões.

2. A versão $B$ mostra 4 prováveis etapas na escritura: $b-b_{1}-b_{2}-b_{3}$ :

b: datiloscrito completo;

$\mathrm{b}_{1}$ : rasuras a máquina;

$\mathrm{b}_{2}-\mathrm{b}_{3}$ : rasuras a lápis e a tinta preta.

3. Versão B confrontada com a versão D, Rua Alegre, 12 (ed. cit.), apresenta variantes.

\section{MA-MOE, 275}

REBELO, Marques (Eddy Dias da Cruz 1907-1973)

275. Rua Alegre $n^{\circ} 12$; teatro (MAm)

[Rio de Janeiro, ant. 1940]

Datiloscrito, cópia carbono azul; papel branco, tipo seda; 106 folhas; 25,5 x 20,2 cm; f. 1: pequenos rasgamentos na borda direita; f. 1-15: vinco na margem esquerda; sinais de fungo; f. 1: marcas de ferrugem na margem esquerda; manchas de carbono; f. 106: furo; escrita: no anverso: 1, 3-106, no anverso e no verso: f. 2 ; f. 1: capa com autoria e título: "Marques Rebêlo | Rua Alegre, 12"; f. 106: assinatura a tinta preta: "Marques Rebêlo"; folhas numeradas a lápis preto: 1-105; rasuras a máquina, a lápis, a tinta preta, a tinta azul e a lápis azul (f. 35); fólios numerados pela pesquisa: (1)(1) (1) (6).

Notas da pesquisa:

1. Ms na vertente Mário de Andrade mentor.

2. Data atestada com base na publicação da peça Rua Alegre, 12. Local atestado pelo fato de MaR morar no Rio de Janeiro.

3. Em 1940 foi publicada Rua Alegre, 12 (Curitiba, Guaíra) (V. MA-MOE, 273, nota 3).

4. Na série correspondência Mário de Andrade, no IEB-USP, não há carta de MaR que comprove o envio do ms.

5. MA conservou em seu arquivo 3 versões de Rua Alegre, 12 (V. MA-MOE, 273 e MAMOE, 274). 
Estudo genético:

1. Rua Alegre, 12 apresenta-se em 3 versões. (V. análises documentárias das versões A e B: MA-MOE, 273 e MA-MOE, 274). Há variantes entre essas três versões.

2. A versão $C$ mostra 6 prováveis etapas na escritura: $c-c_{1}-c_{2}-c_{3}-c_{4}-c_{5}$ :

c: datiloscrito completo;

$\mathrm{c}_{1}$ : rasuras a máquina;

$c_{2}$ : rasura a lápis azul

$\mathrm{c}_{3}-\mathrm{c}_{4}-\mathrm{c}_{5}:$ rasuras a lápis preto, a tinta preta, a tinta azul.

3. A versão $C$ apresenta o texto pronto para publicação.

\section{MA-MOE, 276}

REGO, José Lins do (José Lins do Rego Cavalcanti 1901-1957)

276. Riacho doce; romance (MAc)

[Maceió ou Rio de Janeiro, ant. set. 1939]

O ms apresenta-se em 2 cadernos:

10 caderno: capa azul, lombada preta; $21,7 \times 16,0 \mathrm{~cm}$; sinais de amassado; quarta-capa: perda de parte do revestimento do canto superior esquerdo; miolo: autógrafo a tinta preta e a tinta azul; papel branco, pautado: f. 2-100; impresso: f. 1: "227 | Papelaria | União | Ouvidor |77”; 101 folhas; f. 40: rasgamento na parte superior à esquerda; f. 32: rasgamento na borda inferior; sinais de fungo; letras borradas; manchas de tinta no verso escrita no anverso; f. 1: assinatura: "Jose Lins do Rego"; rasuras a tinta preta, a tinta azul, a lápis tinta e a lápis preto; fólios numerados pela pesquisa: (1)-(1) (1) (3). Notas JLR a tinta azul no verso da capa: contas, a tinta preta e azul: f. 1: contas e números; a tinta preta: f. 2 na margem superior: " 1 caderno de Riacho Doce".

20 caderno: capa azul, lombada preta; $21,7 \times 16,0 \mathrm{~cm}$; sinais de amassado; miolo: autógrafo a tinta preta; papel branco, pautado: f. 2-51; impresso: f. 1: "226 | Papelaria | União | Ouvidor | 77"; 52 folhas; sinais de fungo; letras borradas; manchas de tinta; escrita no anverso; rasuras a tinta preta, a lápis tinta e a lápis preto; fólios numerados pela pesquisa: (1) (1) (4)-(1) (5) (7). Notas JLR a tinta preta: f. 1: contas, f. 2 na margem superior: "2 caderno Riacho Doce".

Notas da pesquisa:

1. Ms na vertente Mário de Andrade colecionador.

2. Data atestada com base na dedicatória de Riacho doce a MA, livro publicado em 1939 (Rio de Janeiro, José Olympio). MA conservou em sua biblioteca um exemplar com a dedicatória: "Para o mestre Mario | de Andrade, com | a velha amizade | José Lins do Rego | 1939, setembro".

3. Em 1935 JLR, que morava em Maceió, mudou-se para o Rio de Janeiro. Por isso a possibilidade de redação do ms em Maceió ou Rio de Janeiro.

4. Na série Correspondência Mário de Andrade não há carta de JLR que comprove o envio do ms. Pode ter chegado a MA após a publicação do livro.

5. O texto de crítica "Riacho doce", de MA, está no livro $O$ empalhador de passarinho (São Paulo, Livraria Martins Editora). 
Estudo genético:

1. O ms apresenta-se em uma única versão, A, que mostra diferentes etapas na escritura a serem tratadas de forma detida em trabalho específico.

2. Há variantes entre a versão A e a versão $\mathrm{B}$, Riacho doce (ed. cit.).

MA-MOE, 277

RESENDE, Henrique (1899-1973)

277. Os meus poemas sentimentaes; Contos da terra verde: ("Desce o rio, lento, pesadão, mollengo.") e ("Hontem a lavoura escaldava sob o veranico."); poesia (MAm)

[Cataguases, ant. 23 nov. 1927]

Autógrafo a tinta preta; papel beje; 1 papel dobrado ao meio formando 2 folhas; 19,4 $\mathrm{x}$ 15,4/15,5 cm; vincos; sinais de fungo; escrita no anverso e no verso: f. 1, escrita no anverso: f. 2; assinatura no final de cada poema: "Henrique Resende"; poemas numerados pelo escritor: I, 2, 3; rasuras a tinta preta; fólios numerados pela pesquisa: (1)-(2).

Nota MA a tinta preta: sugestão de substituição no último verso do poema "Hontem a lavoura escaldava sob o veranico.": no lugar de "e o milho salta nos debulhadores." indica: "o milho salta nos debulhadores...".

Anexo:

Envelope branco; 12,4 x 15,5 cm; sinais de fungo; fólio numerado pela pesquisa: (2). Nota MA a lápis preto: "Henrique de Rezende.

Notas da pesquisa:

1. Ms na vertente Mário de Andrade mentor.

2. Local e data atestados com base na carta de HR a MA, de Cataguases em 23 de novembro de 1927, na qual se lê: "A razão maior desta carta | é o agradecimento que venho trazer a você $\mid$ pelas suas referencias em cartas ao Fusco e ao Camil- | lo, e em nota no D. Nacional, ao meu $1^{\circ} \mid$ Canto da terra verde. Estes cantos são 5. Ahi | vão 2 pra você conhecer e me aconselhar. | Mas aconselhar com aquella mesma fran- | queza bôa com que você tem aconselhado os | outros de cá". (Ref.: série Correspondência Mário de Andrade; sub-série Correspondência passiva: MA-C-CPL, $\mathrm{n}^{\circ}$ 6104)

3. Contos da terra verde estão publicados em Poemas cronológicos (Cataguazes, Verde editora, 1928). MA conservou um exemplar em sua biblioteca com a dedicatória: "Pra você, Mario amigo, | com | a | baita | AMISADE | da gente | Rosario Fusco | Ascanio Lopes | Henrique de Resende".

\section{Estudo genético:}

1. O ms apresenta-se em uma única versão, $A$, que mostra 2 etapas na escritura: a-a $a_{1}$ : a: autógrafo completo; $\mathrm{a}_{1}$ : rasuras a tinta preta. 
2. Versão A confrontada coma versão B, em Poemas cronológicos (ed. cit.), exibe poucas variantes, das quais a inclusão dos títulos: "As usinas" para "Desce o rio, lento, pesadão, mollengo." e "As lavouras" para "Hontem a lavoura escaldava sob o veranico".

MA-MOE, 278

RESENDE, Henrique (1899-1973)

278. O solar que foi dos meus avós: ("Na sala da fazenda, a mais ampla e a mais severa"), ("Senzala da fazenda dos meus avós..."), (“Ao fundo do grande salão de jantar"); poesia (MAm)

[Cataguases, ant. 13 dez. 1927]

Datiloscrito original, fita preta; papel branco, pautado no anverso, filigrana; 3 folhas; 25,9/26,0 x 18,9 cm; irregularidades na borda superior; vincos; sinais de fungo; escrita no verso; assinatura na margem inferior de cada folha: "Henrique de Resende.”; o título está repetido na margem superior das f. 2-3; poemas numerados pelo escritor: I-III; rasuras a máquina e a tinta preta; fólios numerados pela pesquisa: (1)-(3).

Notas MA a lápis preto: sugestões de substituição: no v. 2 de "Senzala da fazenda dos meus avós..." indica a troca da expressão "a pouco e pouco" por "pouco a pouco"; no v.4 de "Ao fundo do grande salão de jantar", no lugar de "e os dois vetustos" propõe "e as duas vetustas".

Notas da pesquisa:

1. Ms na vertente Mário de Andrade mentor.

2. Local e data atestados com base na carta de HR a MA, da Fazenda do Rochedo, 13 de dezembro de 1927, na qual escreve: "E como os Poemas cronológicos sáem até o | fim do mez, ou principios de janeiro, estando já $\mid$ se compondo a minha parte, quero uma $\mid$ nova opinião sua sobre os 3 junto a esta. | Uma opinião como as suas de sempre: sincera | e leal. E nóte uma coisa: não aporrinharei | mais. Os 3 poemas que seguem | são meras copias do existente. A sala, a senzala e a ermi- $\mid$ da desta fazenda de onde lhe escrevo..”. (Ref.: série Correspondência Mário de Andrade; sub-série Correspondência passiva: MA-C-CPL, $\mathrm{n}^{\circ}$ 6105)

3. O solar que foi dos meus avós está publicado em Poemas cronológicos (ed. cit.) (V. MA-MOE, 277, nota 3).

Estudo genético:

1. O ms apresenta-se em uma únca versão, A, que mostra em "Na sala da fazenda, a mais ampla e a mais severa" 2 etapas na escritura: a-a avós...", "Ao fundo do grande salão de jantar" 3 etapas na escritura: a-a 1 -a $a_{2}$ :

a: autógrafo completo;

$\mathrm{a}_{1}$ : rasuras a máquina;

$\mathrm{a}_{2}$ : rasuras a tinta preta

2. Versão A confrontada com a versão B, em Poemas cronológicos (ed. cit.), mostra variantes, das quais a inclusão dos títulos: "A sala" para "Na sala da fazenda, a mais 
ampla e a mais severa", "A senzala" para "Senzala da fazenda dos meus avós...", "A ermida" para "Ao fundo do grande salão de jantar".

3. As sugestões de MA são acatadas por HR na versão B.

MA-MOE, 279

RESENDE, Otto Lara (Otto Oliveira de Lara Resende 1922-1992)

279. Poema para Mário de Andrade; poesia (MAm)

Cassino da Pampulha [Belo Horizonte], 10 set. 1944

Autógrafo a tinta preta; papel branco; 2 folhas; f. 1 : $58,4 / 60,1$ x $17,0 / 17,5 \mathrm{~cm}$, f. 2 : $58,3 / 60,8 \times 17,0 / 17,5 \mathrm{~cm}$; irregularidades nas bordas direita e esquerda; borda inferior recortada; pequenos rasgamentos nas bordas esquerda e direita; vincos; sinais de fungo; f. 1: furo na parte superior; escrita no anverso; f. 2: assinatura, local, horário e data: "Otto Lara de Rezende | Casino da Pampulha | 2,15 do dia 10-9-44 | (Escrito às 2 horas da noite)"; folha numerada pelo escritor: 2; rasuras a tinta preta; fólios numerados pela pesquisa: (1)-(2).

Notas da pesquisa:

1. Ms na vertente Mário de Andrade mentor.

2. Não há carta de OLR na série Correspondência Mário de Andrade, no IEB-USP, que comprove o envio do ms.

3. O poema permaneceu inédito.

Estudo genético:

1. MA conservou 2 versões de Poema para Mário de Andrade. A acima registrada foi considerada versão A (V. análise documentária da versão B: MA-MOE, 280).

2. A versão A mostra 2 etapas na escritura: $a-a_{1}$ :

a: autógrafo completo;

$\mathrm{a}_{1}$ : rasuras a tinta preta.

3. Há variantes entre as versões A e B.

MA-MOE, 280

RESENDE, Otto Lara (Otto Oliveira de Lara Resende 1922-1992)

280. Poema para Mário de Andrade; poesia (MAm)

Cassino da Pampulha [Belo Horizonte, post. 10 set. 1944]

Datiloscrito, cópia carbono azul; papel branco, filigrana: "CORU-BOND | IND. BRAS."; 2 folhas; 32,6 x 22,1 cm; vincos; sinais de fungo; manchas de carbono; escrita no anverso; f. 2: autoria, local, data e horário: "Otto Lara Rezende | (Cassino de Pampulha,10-IX-44;2,15 da noite)"; folha numerada pelo escritor: 2; rasura a máquina; fólios numerados pela pesquisa: (1)-(2). 
Notas da pesquisa:

1. Ms na vertente Mário de Andrade mentor.

2. OLR passou a limpo no ms o poema que escrevera no Cassino da Pampulha em 10 de setembro de 1944. MA conservou as duas versões (V. análise documentária da versão A: MA-MOE, 279).

3. Não há carta de OLR na série Correspondência Mário de Andrade, no IEB-USP, que comprove o envio do ms.

4. O poema permaneceu inédito.

Estudo genético:

1. O ms foi considerado versão $B$ pela pesquisa, e mostra 2 etapas na escritura: $a-a_{1}$ : a: datiloscrito completo; $\mathrm{a}_{1}$ : rasura a máquina.

2. Há variantes entre as versões A e B de Poema para Mário de Andrade.

\section{MA-MOE, 281}

\section{RODRIGUES, Augusto}

281. Questionarios sobre dansas brasileiras; aspéto social do frêvo; Questionarios sobre dansas brasileiras; coreografia do frêvo; folclore (MAm)

[Recife], s/ data

Autógrafo a tinta preta; papel beje, tipo jornal; 10 folhas; 32,7 x 22,5 cm; f. 1-2: pequeno rasgamento na borda direita superior; f. 4: pequenos rasgamentos na borda superior; f. 4-5: irregularidades na borda inferior; f. 8: pequenos rasgamentos na borda direita superior; f. 9: pequenos rasgamentos na borda direita; vinco; sinais de fungo; escrita no anverso; folhas numeradas pelo escritor a tinta preta: 2-5, 2-4; rasuras: a tinta preta; fólios numerados pela pesquisa: (1)-(1) (0). F. 1: bilhete de AuR a MA e etiqueta MA; s/ data; s/ assinatura; forma de tratamento: "Mario:"; margem superior: dentificação do ms em sua biblioteca: "B/ VI/ e-op.25/ 139"

(Ref. Cruzada: série Correspondência Mário de Andrade; sub-série Correspondência passiva: MA-C-CPMMA, n 6206)

Notas da pesquisa:

1. Ms na vertente Mário de Andrade mentor.

2. No bilhete acima registrado se lê: "Mario: |Esses são os dois questionários | que vou remeter para entendidos $\mid$ do Recife. | V. tem alguma sugestão a apresentar | para dar mais força as perguntas?".

\section{Estudo genético:}

1. O ms apresenta-se em uma única versão, A, que mostra 2 etapas na escritura: a-a a $_{1}$ a: autógrafo completo;

$\mathrm{a}_{1}$ : rasuras a tinta preta. 
MA-MOE, 282

ROSA, Roldão Mendes

282. Paz; Carinho triste; Distância; Quase bom; A volta das horas perdidas; Elegia da infância perdida; Ronda do meu silêncio; poesia (MAm)

[Santos, 1943 ou post. 1943]

Datiloscrito, cópia carbono roxo; papel beje, tipo jornal; 7 folhas; 32,4/32,5 x 21,8/22,0 cm, com variações em mm; f. 1-3, 6: borda esquerda recortada; f. 1-4, 6-7: rasgamentos na borda direita; f. 4: rasgamento na borda esquerda vincos; f. 4-5,7: bordas esquerda e inferior recortadas; sinais de fungo; manchas de carbono; escrita no anverso; rasuras a máquina; fólios numerados pela pesquisa: (1)-(7).

Paz:

Dedicatória embaixo do título: "pra Ney Guimarães"; data no final do poema: “(1941)".

Nota MA a lápis preto na margem superior à esqurda: "Bem bom”.

Carinho triste:

Data no final do poema: “(1942)".

Notas MA: a lápis preto: comentários a alguns trechos sublinhados: "pau", a lápis vermelho: indicação de autoria: "Roldão Mendes Rosa | Santos".

Distância:

Data no final do poema: “(1942)”.

Quase bom:

Data no final do poema: "1942".

Nota MA a lápis preto: correção ortográfica.

A volta das horas perdidas:

Data no final do poema: “(1943)".

Nota MA a lápis preto: 3 traços verticais na margem esquerda destacando versos.

Elegia da infância perdida:

Data no final do poema: “(1943)".

Ronda do meu silêncio:

Data no final do poema: “(1943)".

Nota MA a lápis preto: correção ortográfica.

Notas da pesquisa:

1. Ms na vertente Mário de Andrade mentor.

2. Data atestada com base nas informações, no ms, do ano de criação de cada poema.

3. Não consta carta de RMR na série Correspondência Mário de Andrade, no IEB-USP, que comprove o envio do ms. 
4. Os poemas Paz, Carinho triste e Quase bom foram publicados em Poemas do não e da noite (São Paulo/ Santos, Hucitec/ Secretaria da Cultura, 1992).

5. Distância, A volta das horas perdidas, Elegia da infância perdida e Ronda do meu silêncio permaneceram inédios.

\section{Estudo genético:}

1. O ms apresenta-se em uma única versão, A, que mostra em Carinho triste e Distância 1 etapa na escritura, e em Paz, A volta das horas perdidas, Elegia da infância perdida e Ronda do meu silêncio 2 etapas na escritura: $\mathrm{a}-\mathrm{a}_{1}$ :

a: datiloscrito completo;

$\mathrm{a}_{1}$ : rasuras a máquina.

2. Versão A de Paz, Carinho triste e Quase bom confrontada com a versão B em Poemas do não e da noite (ed. cit.), apresenta variantes.

\section{MA-MOE, 283}

\section{ROSENDO}

283. Ave Maria; crônica (MAm)

S/ local, maio 1942

Datiloscrito, cópia carbono azul; papel branco; 1 folha; 32,3/32,5 x 22,2 cm; borda direita cortada; pequenos rasgamentos na borda superior; vincos; sinais de fungo; escrita no anverso; autoria abaixo so título: "Crônica de Rosendo"; data no final do texto: "maio de 42)"; rasuras a máquina, a tinta preta e a tinta azul; fólio numerado pela pesquisa: (1). Nota Ro no final do do texto a máquina: "(Rosendo é o pseudônimo que eu adoto em crônicas.)".

$\underline{\text { Nota MA a lápis vermelho: grifo em trecho do conto: "E me pareceis que vindes de }}$ séculos".

Nota da pesquisa:

1. Ms navertente Mário de Andrade mentor.

Estudo genético:

1. O ms apresenta-se em uma única versão, A, que mostra 4 prováveis etapas na escritura: $a-a_{1}-a_{2}-a_{3}$ :

a: datiloscrito completo;

$\mathrm{a}_{1}$ : rasuras a máquina;

$\mathrm{a}_{2}-\mathrm{a}_{3}$ : rasuras a tinta preta e a tinta azul. 
MA - MOE, 284

RUBIÃO, Murilo (1916-1991)

284. O pirotécnico Zacarias; conto (MAm)

[Rio de Janeiro], 3 abr. 1943

Recortes do conto publicado na revista $O$ Cruzeiro; f. 1-2: impresso em 4 cores, f. 34: impresso em preto e branco: tiras coladas em papel sulfite branco; f. 1: 32,8/33,0 x 23,2/23,3 cm; f. 2: 32,5/32,9 x 23,3/23,4 cm; f. 3-4: 32,7 x 21,9 cm; f. 1: bordas esquerda, direita e inferior recortadas; f. 2: bordas direita e inferior recortadas; vincos; sinais de fungo; 2 furos para arquivamento; f. 2: letras apagadas nos parágrafos 7-8; f. 1: conto impresso no anverso, no verso: seção de humor "Garotas na Serra", f. 2: conto impresso no verso, anverso: continuação de "Garotas na Serra"; f. 1-2: ilustrações de Percy Deane e data e título do periódico na margem inferior, no anverso e no verso: "3 de Abril de 1943 | O CRUZEIRO”; f. 1-2: páginas numeradas: 31-34; fólios numerados pela pesquisa: (1)-(5).

Anexos:

1) Envelope branco, timbrado: "UNIVERSIDADE DE MINAS-GERAIS | 7 de Setembro de 1927 | DIRECTORIO DOS ESTUDANTES | -DA- | FACULDADE DE DIREITO"; 12,9 x 25,8/25,9 cm; rasgamentos nas bordas; sinais de fungo; rasura a tinta azul anulando o timbre; fólio numerado pela pesquisa: (6). Nota MuR a tinta azul: "Exmo Sr. | Fernando Sabino | Em mãos".

Nota MA a lápis vermelho sobre o autógrafo a tinta azul, anulando-o: "Murilo Rubião | Contos".

2) Ms MA: Murilo Rubião; crítica; [São Paulo, ant. 16 jun. 1943]; autógrafo a tinta preta; papel branco, timbrado: MINISTÉRIO DA EDUCAÇÃO E SAÚDE | INSTITUTO NACIONAL DO LIVRO"; 1 folha; 23,1 x 16,5 cm; vinco; sinais de fungo; escrita no anverso e no verso; rasuras a tinta preta; fólio numerado pela pesquisa: (7).

(Ref. cruzada: série Manuscritos Mário de Andrade -MMA)

3) Carta de MuR a MA: datada: "Belo Horizonte, 23-7-43"; forma de tratamento: "Mario de Andrade"; assinada: "Murilo"; datiloscrito, cópia carbono roxo; papel branco, filigrana: "VICTORIA | INDUST. BRASIL."; 2 folhas; 26,6 x 20,9 cm; vincos; sinais de fungo; escrita no anverso e no verso; páginas numeradas pelo escritor: 2-4; fólios numerados pela pesquisa: (8)-(9).

(Ref. cruzada: série Correspondência Mário de Andrade - sub-série Correspondência passiva; MA-C-CPMVA, $n^{\circ}$ 6232)

Notas da pesquisa:

1. Ms na vertente Mário de Andrade mentor.

2. O ms traz a publicação de "O Pirotécnico Zacarias", na revista $O$ Cruzeiro, 31 anos antes da edição em livro: O pirotécnico Zacarias (São Paulo, Ática, 1974).

3. A pesquisa classificou o envelope juntamente com o $\mathrm{ms}$ de $O$ pirotécnico Zacarias, porém, ao que tudo indica, MA utilizou-o para acondicionar os demais ms de Murilo Rubião guardados em seu arquivo: Alfredo, Marina, a inatingível, Mariazinha. Os vincos do ms de $O$ pirotécnico Zacarias correspondem ao tamanho do envelope, mas isso não comprova que tenha sido encaminhado a MA em seu interior. 
4. O ms Murilo Rubião conserva as impressões da primeira leitura de MA aos contos do jovem mineiro. Ao longo do texto estão referências a $O$ pirotécnico Zacarias e $O$ exmágico da Taberna Minhota; este não foi, porém, conservado por MA.

5. A data do ms Murilo Rubião foi atestada com base em carta que MA enviou para MuR em 16 de junho de 1943, nela consta uma nova versão, B, do ms. Para introduzir seus comentários na missiva, MA redigiu: "Não dá tempo para ler os contos que tenho aqui, mas dá pra copiar umas notas que tomei na primeira leitura". (ANDRADE, Mário de. Mário e o Pirotécnico Aprendiz: cartas de Mário de Andrade e Murilo Rubião. Marcos Antonio de Moraes, org. Belo Horizonte/São Paulo, Editora UFMG/IEB/Editora Giordano, 1995, p. 32-34)

6. A carta de MuR a MA, acima registrada, guarda a resposta aos comentários de MA na missiva de 16 de junho de 1943. Entre considerações sobre o próprio fazer literário, o remetente diz estar elaborando alguns contos, confessa o sentimento de dificuldades durante o processo de criação, abordando particularmente $O$ pirotécnico Zacarias e $O$ ex-mágico da Taberna Minhota; solicita, ainda, que MA e Gilda de Moraes Rocha nome de solteira de Gilda de Melo e Souza - leiam seu conto "Eunice e as flores amarelas" publicado em Roteiro, São Paulo, 15 jul. 1943. (ANDRADE, Mário de. Op. cit., p. 39-44)

Estudo genético:

1. O ms de $O$ pirotécnico Zacarias apresenta-se em uma única versão, A, que mostra 1 etapa na escritura.

2. O ms Murilo Rubião apresenta-se em uma única versão, A, que exibe 2 etapas na escritura: a-a 1 :

a: autógrafo completo;

$\mathrm{a}_{1}$ : rasuras a tinta preta.

3. Versão A confrontada com a versão B, em O pirotécnico Zacarias (ed. cit.), mostra variantes.

4. A versão A de Murilo Rubião foi confrontada com a versão B, na carta de MA aMur, de 16 de junho de 1943, (Mário e o Pirotécnico Aprendiz: cartas de Mário de Andrade e Murilo Rubião, ed. cit. p. 32-34), e exibe variantes.

\section{MA-MOE, 285}

RUBIÃO, Murilo

285. Alfredo; conto (MAm)

[Belo Horizonte] maio 1943

Datiloscrito, cópia carbono azul; papel branco, timbrado em vermelho: "SERVIÇO PUBLICO DO ESTADO DE MINAS GERAIS | CORRESPONDÊNCIA EXPEDIDA"; 5 folhas; 31,8 x 22,0 cm; vincos; sinais de fungo: f. 5; manchas de carbono; margem esquerda: 2 furos para arquivamento; escrita no anverso; f. 1: autoria embaixo do título: "Conto de Murilo Rubião"; f. 5: assinatura e data a tinta preta no final do texto: "Murilo Rubião | Maio de 43"; folhas numeradas pelo escritor: 2-5; rasuras a máquina e a tinta preta; fólios numerados pela pesquisa: (1)-(5). 


\section{Anexos:}

1) Bilhete de MR a MA; [dez. 1943]; forma de tratamento: "Mário de Andrade."; assinado: "Murilo Rubião"; autógrafo a tinta preta; papel branco, timbrado: "SERVIÇO DE RÁDIO-DIFUSÃO | PRI - 3 | DE BELO HORIZONTE | Rádio Inconfidência de Minas Gerais"; 1 folha; 14,4 x 21,6 cm; vincos; sinais de fungo; escrita no anverso e no verso; mancha de tinta preta na margem inferior; manchas de carbono azul; fólio numerado pela pesquisa: (1).

2) Carta de MA a MR; datada: "27-XII-43"; forma de tratamento: "Murilo"; assinada: "M."; datiloscrito, cópia carbono roxo; autógrafo a tinta preta; papel beje; 1 folha; 32,3 x 22,0 cm; pequenos rasgamentos nas bordas direita, superior e inferior; vincos; sinais de fungo; pequenos rasgamentos causados pelo ressecamento da tinta do autógrafo; escrita no anverso; fólio numerado pela pesquisa: (1).

\section{Notas da pesquisa:}

1. Ms na vertente Mário de Andrade mentor.

2. Alfredo foi acondicionada por MA em envelope branco com autógrafo de MR a tinta azul onde se lê: "Exmo Sr. | Fernando Sabino | Em mãos"; sobre o autógrafo a nota MA a lápis vermelho: "Murilo Rubião | Contos". No interior do mesmo envelope foram acondicionados também outros $\mathrm{ms}$ de MR: O pirotécnico Zacarias, Marina, a intangivel, Mariazinha (V. MA-MOE, 284, nota 3).

3. O bilhete acompanha o envio do ms Alfredo, com os seguintes dizeres: "Junto lhe envio 'Alfredo', um trabalho meu, | realizado em maio do corrente ano.". Sua data foi atestada com base em carta de MA a MR, de 27 dez. 1943, onde o remetente escreve: "acabo de receber o 'Alfredo', e respondo já por causa da sua | consulta de agora.". Portanto, o ms com data de maio de 1943 é enviado a MA apenas em dezembro. No mesmo bilhete, o jovem mineiro pede ajuda de MA para a escolher um de seus contos a integrar antologia: [...] Um camarada daqui está organizando | uma antologia de contistas novos de Minas. | Por isso - antes de receber resposta da minha última | carta - desejava saber de v. qual dos três contos |- 'Magico', 'Marina' e 'Alfredo' - devo entregar | aos organizadores da coletânea.". A "última carta" a que faz referência, é aquela que se junta ao ms de Marina, a intangível, de 17 dez. 1943 (V. MA-MOE, 286).

4. A carta de MA a MR, de 27 dez. 1943, traz o comentário a Alfredo e ao estilo de MR construir seus contos fantásticos.

\section{Estudo genético:}

1. O ms apresenta-se em uma única versão $A$, que mostra 3 etapas na escritura: $a-a_{1}-a_{2}$ :

a: datiloscrito completo;

$\mathrm{a}_{1}$ : rasuras a máquina;

$\mathrm{a}_{2}$ : rasuras a tinta preta. 
MA - MOE, 286

RUBIÃO, Murilo (1916-1991)

286. Marina, a intangível; conto (MAm)

Belo Horizonte, 15 dez. 1943

Datiloscrito, cópia carbono roxo; papel branco, tipo seda, timbrado em vermelho: "SERVIÇO PUBLICO DO ESTADO DE MINAS GERAIS | CORRESPONDÊNCIA EXPEDIDA"; 7 folhas; 31,7 x 21,9 cm; vincos; sinais de fungo; folhas amassadas; margem esquerda: furos para arquivamento; f. 7: sinal de digital; escrita no anverso; $f$. 1: assinatura a máquina embaixo do título: "Conto de Murilo Rubião"; f. 7: indicação de local, data e assinatura em autógrafo a tinta preta: "Belo Horizonte, 15 de Dezembro de 1943 | Murilo Rubião"; folhas numeradas pelo escritor: 2-7; rasuras: a máquina, a tinta preta; fólios numerados pela pesquisa: (1)-(7).

\section{Anexo:}

Carta: de MuR a MA; datada: "B.H. 17-12-43"; forma de tratamento: "Mário de Andrade,"; assinada: "Um grande abraço do Murilo Rubião"; datiloscrito, cópia carbono roxo; papel branco; 1 folha; 32,7 x 22,0 cm; vincos; sinais de fungo; escrita no anverso e no verso; página numerada pelo escritor: 2; fólio numerado pela pesquisa: (1).

Nota MuR: verso: autógrafo a tinta preta: "Endereço: MURILO RUBIÃO | Goitacazes, $185^{\prime}$.

Notas da pesquisa:

1. Ms na vertente Mário de Andrade mentor.

2. O ms foi encaminhado a MA junto com a carta de 17 de dezembro de 1943, onde MuR pede a opinião do destinatário: "Junto a esta, segue o meu último conto - 'Marina, a Intangível. | Desejava muito a sua opinião sôbre êle, pois é o primeiro trabalho que | consigo realizar, depois de uma inatividade forçada de cinco meses. [...] Mário: a sua opinião sôbre o conto que lhe envio, muito me | ajudará. Os amigos de cá (Hélio, Oto, Jair, etc.) gostaram. Mas não | posso confiar neles. São mais amigos do que críticos. Muito mais.”. (ANDRADE, Mário de. Mário e o Pirotécnico Aprendiz: cartas de Mário de Andrade e Murilo Rubião. Marcos Antonio de Moraes, org. Belo Horizonte/São Paulo, Editora UFMG/IEB/Editora Giordano, 1995, p. 48-50). Os amigos referidos na carta são respectivamente: Hélio Pellegrino, Otto Lara Resende e Jair Rebelo Horta.

3. Marina, a intangivel foi publicado em Os dragões e outros poemas. [Belo Horizonte], Movimento - Perspectiva, [1965].

4. O ms de Marina, a intangível foi acondicionada por MA em envelope branco com autógrafo de MuR a tinta azul onde se lê: "Exmo Sr. | Fernando Sabino | Em mãos"; sobre o autógrafo a nota MA a lápis vermelho: "Murilo Rubião | Contos". No interior do mesmo envelope foram acondicionados também outros ms de MuR: $O$ pirotécnico Zacarias, Alfredo, Mariazinha (V. MA-MOE, 284, nota 3). 
Estudo genético:

1. O ms apresenta-se em uma única versão, A, que mostra 3 etapas na escritura: $a-a_{1}-a_{2}$ : a: datiloscrito completo;

$\mathrm{a}_{1}$ : rasuras a máquina $\mathrm{a}_{2}$ : rasuras a tinta preta

2. Versão A confrontada com a versão B em Os dragões e outros poemas (ed. cit.), exibe variantes.

\section{MA-MOE, 287}

RUBIÃO, Murilo

287. Mariazinha; conto (MAm)

[Belo Horizonte], s/ data

Datiloscrito, cópia carbono preto; papel branco; 5 folhas; 34,5 x 18,6 cm; vincos; sinais de fungo; f. 4: sinal de digital; escrita no anverso; f. 5: assinatura: a tinta azul; folhas numeradas pelo escritor: 2-5; rasuras: a máquina, a tinta azul; fólios numerados pela pesquisa: (1)-(5).

\section{Notas da pesquisa:}

1. Ms na vertente Mário de Andrade mentor.

2. Mariazinha foi acondicionada por MA em envelope branco com autógrafo de MuR a tinta azul onde se lê: "Exmo Sr. | Fernando Sabino |Em mãos"; sobre o autógrafo a nota MA a lápis vermelho: "Murilo Rubião | Contos". No interior do mesmo envelope foram acondicionados também outros ms de MuR: O pirotécnico Zacarias, Marina, a intangivel, Alfredo (V. MA-MOE, 284, nota 3).

3. Não consta na correspondência travada entre MA e MuR menção ao ms Mariazinha.

\section{Estudo genético:}

1. O ms apresenta-se em uma única versão, A, que mostra 3 etapas na escritura: $a-a_{1}-a_{2}$ : a: datiloscrito completo;

$\mathrm{a}_{1}$ : rasuras a máquina;

$\mathrm{a}_{2}$ : rasuras a tinta preta.

\section{MA-MOE, 288}

\section{SANTOS, Virgílio Paula (1920-?)}

288. No subúrbio do tempo, Nú; contos, poema (MAc)

$\mathrm{S} /$ local, s/ data

Datiloscrito, cópia carbono preto; datiloscrito original, fita vermelha: f. 3: epígrafe; papel branco; 78 folhas; f. 1-26, 32-37, 44-78: 31,6 x 21,8 cm, com variações em mm; f. $27-29,31-31: 32,5$ x 22,0 cm, f. $30: 32,0$ x 22,0 cm; f. $38-39,41-43: 32,5$ x 22,0 cm, f. 40: 37,6 x 22; f. 8-12: borda inferior recortada; f. 10: mancha de tinta preta no texto; manchas de carbono; f. 22-26: furos; f. 40: vinco horizontal; sinais de fungo; 2 
furos para arquivamento na margem esquerda; escrita no anverso; folhas numeradas pelo escritor; f. 1: autoria e título: "VIRGILIO PAULA SANTOS | NO SUBÚRBIO DO TEMPO | Contos"; f. 2: dedicatória: "A Herminio Saccheta, | que me viu só, chorando na rua e me ofereceu um lenço. | Não adiantou nada, quasi nada, mas serviu para que | o pó não grudasse tanto."; f. 13: autoria e título: "Virgilio Paula Santos | Mensagem de longes terras"; f. 33: autoria e título: "Virgilio Paula Santos | Folhas verdes no outono"; f. 77: poema de autoria do próprio escritor; f. 78: índice sem a numeração das páginas; rasuras a máquina: cópia carbono e original fita preta, a tinta preta; f. 40: trecho de papel colado com rasura em datiloscrito, cópia carbono; fólios numerados pela pesquisa: (1)-(7) (8).

O ms apresenta os contos:

Quadro modernista, Fantasia coitada, Mensagem de longes terras, Acenando adeus, prece do homem realista, Sob um título qualquer, Folhas verdes no outono, Enquanto não acontece nada, Contaconto, Numa taça de champanha, Um violino canta, Quebra-luz azul, cortina invisivel.

Notas da pesquisa:

1. Ms na vertente Mário de Andrade colecionador.

2. Na série correspondência Mário de Andrade, no IEB-USP, não constam cartas de VPS. Não foi possível atestar a adata do envio do ms.

3. Os contos permaneceram inéditos.

Estudo genético:

1. O ms apresenta-se em uma única versão, A

2. Fantasia coitada mostra 2 etapas na escritura: a-a $a_{1}$ :

a: datilsocrito completo;

$\mathrm{a}_{1}$ : rasuras a tinta preta.

3. Quadro modernista, Mensagem de longes terras, Acenando adeus, Prece do homem realista, Contaconto, Numa taça de champanha, Um violino canta, Cortina invisível e Quebra-luz azul mostram 3 etapas na escritura: a-a $\mathrm{a}_{1}-\mathrm{a}_{2}$ :

a: datiloscrito completo;

$\mathrm{a}_{1}$ : rasuras a máquina;

$\mathrm{a}_{2}$ : rasuras a tinta preta.

4. Sob um título qualquer, Folhas verdes no outono e Enquanto não acontece nada mostram 4 etapas na escritura: $\mathrm{a}-\mathrm{a}_{1}-\mathrm{a}_{2}-\mathrm{a}_{3}$ :

a: datiloscrito completo;

$\mathrm{a}_{1}$ rasuras a máquina;

$a_{2}-a_{3}$ : rasuras a tinta e em datiloscrito original. 
MA-MOE, 289

SILVEIRA, Valdomiro

289. Como se deve escrever; conferência (MAc)

São Paulo, 1935

Autógrafo a tinta preta; papel branco, filigrana: f. 1; 12 folhas; f. 1: 33,1 x 22,1 cm, f. 2-12: 28,0 x 21,5 cm; f. 1: borda esquerda cortada; f. 3: rasgamentos na borda direita; f. 4: pequenos rasgamentos na borda esquerda; f. 5: rasgamentos nas bordas direita e esquerda; vincos; sinais de fungo; f. 8: 3 furos na margem esquerda; f. 9: 4 furos na margem direita: o primeiro e o último com rasgamento; f. 3: manchas de carbono roxo no verso; f. 10: manchas de carbono roxo e de tinta azul; escrita: f. 1-9, 11-12: anverso, f. 10: no anverso e no verso; folhas numeradas pelo escritor: 2-11; rasuras: a tinta preta; fólios numerados pela pesquisa: (1)-(1) (2).

Nota MA a tinta preta: f. 1: "Valdomiro Silveira | Manuscrito de uma | conferência pronunciada em 1935 | na Associação Acadêmica Al- | vares de Azevedo, da Faculdade | de Direito de São Paulo".

Nota da pesquisa:

1. Ms na versão Mário de Andrade colecionador.

Estudo genético:

1. O ms apresenta 2 versões do mesmo texto: no verso da f. 10 está a versão A de um trecho de Como se deve escrever; a versão B desse trecho está no anverso da f. 7, com o subtítulo "Á beira da estrada". Por isso, o texto integral, no averso, foi considerado versão B.

2. Versão A mostra 2 etapas na escritura: $a-a_{1}$ :

a: autógrafo completo;

$\mathrm{a}_{1}$ : rasuras a tinta preta.

3. Versão B mostra também 2 etapas na escritura: $b-b_{1}$ :

b: autógrafo completo;

$\mathrm{b}_{1}$ : rasuras a tinta preta.

\section{MA-MOE, 290}

SIMÕES, Eduardo Valente (1906-?)

290. Espiritismo; poesia (MAm)

[São Paulo, ant. 24 mar. 1931]

Datiloscrito, cópia carbono preto, papel branco, filigrana; 1 folha; 32,8 x 22,2 cm; borda esquerda cortada; pequeno rasgamento na borda inferior à direita; vincos; sinais de fungo; manchas de carbono; escrita no anverso; assinatura a tinta preta e a máquina no final do poema: "Eduardo Simões | Eduardo Simões"; rasuras a máquina e a tinta preta; fólio numerado pela pesquisa: (1). 
Notas da pesquisa:

1. Ms na vertente Mário de Andrade mentor.

2. Local e data atestados com base na carta de EVS a MA, de São Paulo em 24 de março de 1931, junto da qual enviou o poema: “[...] leia 'Espi- | ritismo', o poema que lhe mando | com esta e cuja publicação na 'Revis- | ta Nova' espero seja feita". (Ref.: série Correspondência Mário de Andrade - sub-série Correspondência passiva; MA-C-CPL, $\mathrm{n}^{\circ}$ 6467)

3. O poema encontra-se publicado em Fundo de Gaveta (São Paulo, Roswitha Kempf/Editores, 1983).

\section{Estudo genético}

1. O ms apresenta-se em uma única versão, $A$, que mostra 3 etapas na escritura: $a-a_{1}-a_{2}$ : a: datiloscrito completo;

$\mathrm{a}_{1}$ : rasura a máquina; $\mathrm{a}_{2}$ : rasuras a tinta preta.

2. Versão A confrontada com a versão B em Fundo de gaveta (ed. cit.), exibe variantes.

\section{MA-MOE, 291}

\section{SOARES, Camilo}

291. Canções d'onde eu nasci; poesia (MAm)

[Cataguases], janeiro 1927

Autógrafo a tinta preta; papel branco; 3 folhas; 22,2 x 13,0/13,1 cm; vincos; sinais de fungo; pequena mancha de tinta roxa; escrita: f. 1: no anverso e no verso; f. 2-3: no anverso; data e assinatura a tinta preta: f. 1 no verso e f. 3 no anverso: "janeiro 27 | Camilo Soares"; o título do poema se repete na margem superior de cada uma das folhas; rasura a tinta preta: f. 2; fólios numerados pela pesquisa: (1)-(3).

Anexo:

Envelope branco; 12,4 x 15,5 cm; rasgado na borda superior; sinais de fungo; fólio numerado pela pesquisa: (1).

Nota MA a lápis preto: "Camilo Soares".

Notas da pesquisa:

1. Ms naMário de Andrade mentor.

2. Na carta de 13 de janeiro de [1928], CS diz a MA: "Es- | tou escrevendo umas Canções | d'onde eu nasci - uma besteira | como todas as outras. Mando | algumas para você e mais uns troços".

3. O envelope era provavelmente utilizado por MA para acondicionar os ms de Camilo Soares que conservou em seu arquivo.

4. Camilo Soares teve um único livro de poemas publicado: O soldado Nicolau ([Rio de Janeiro], Edicões Porta de Livraria, 1970). 
Estudo genético:

1. Ms apresenta-se em uma única versão, $A$, que mostra 2 etapas na escritura: $a-a_{1}$ : a: autógrafo completo;

$\mathrm{a}_{1}$ : rasuras a tinta preta.

MA-MOE, 292

SOARES, Camilo

292. A aleijadinha da cadeira de ródas; Descoberta; Arary; O papão; Inscrição; poesia (MAm)

[Cataguases, ant. 13 jan. 1928]

Autógrafo a tinta roxa; papel branco; 2 folhas; f. 1 : $24,1 / 24,2$ x $16,5 \mathrm{~cm}$, f. 2 : 23,8/24,5 x 16,5/16,6 cm; f. 1: bordas direita e inferior cortadas; f. 2: bordas direita, esquerda e inferior cortadas e borda inferior irregular; f. 1: pequenos rasgamentos na borda inferior; vincos; f. 2: sinais de fungo; f. 1: manchas de carbono com impressão de digital; escrita no anverso e no verso; f. 2: bilhete na margem superior; rasuras a tinta roxa; fólios numerados pela pesquisa: (1)-(2). Conteúdo do bilhete: "Olha vae ai um tal de Kisnet. Poesia velha e sem | título. O Henrique de Resende que pôs este titulo | besta. Sem sentido. Que tal? | Camilo".

A aleijadinha da cadeira de ródas:

Assinatura no final do poema: "Camilo".

Descoberta:

Assinatura no final do poema: "Camilo".

Notas da pesquisa:

1. Ms naMário de Andrade mentor.

2. Local e data atestados com base nas cartas a MA, de Cataguases, em outubro de [1927] e 13 de janeiro de [1928]. Na primerira se lê: "Mando para você troços meus. Fala disso | com sinceridade paulista", na segunda o poeta escreve: "Es- | tou escrevendo umas Canções | d'onde eu nasci - uma besteira | como todas as outras. Mando | algumas para você e mais uns troços".

3. Camilo Soares teve um único livro de poemas publicado: $O$ soldado Nicolau (ed. cit.).

Estudo genético:

1. Descoberta; Arary; O papão; Inscrição apresentam-se em uma única versão, A, que mostram 2 etapas na escritura: $\mathrm{a}-\mathrm{a}_{1}$ :

a: autógrafo completo;

$\mathrm{a}_{1}$ : rasuras a tinta roxa.

2. A aleijadinha da cadeira de ródas apresenta-se em 2 versões. A acima registrada foi considerada versão A pela pesquisa, e mostra 1 etapa na escritura. Na versão B o poema teve o título substituído para A menina da cadeira de ródas (V. a análise documentária da versão B: MA-MOE, 293). 
MA-MOE, 293

SOARES, Camilo

293. A menina da cadeira de ródas; Ballada para minha mãezinha santa; poesia (MAm) [Cataguases], s/ data

Autógrafo a tinta roxa; papel branco, pautado; 1 folha; 22,1 x 16,0/16,3 cm; irregularidades na borda esquerda; cantos com mancha rosada; vincos; sinais de fungo; escrita no anverso; assinatura no final de cada poema: "Camillo"; rasuras a tinta roxa; fólio numerado pela pesquisa: (1).

Notas da pesquisa:

1. Ms na Mário de Andrade mentor.

2. Camilo Soares teve um único livro de poemas publicado: $O$ soldado Nicolau (ed. cit.).

Estudo genético:

1. Ballada para minha mãezinha santa apresenta-se em uma única versão, A, que mostra 1 etapa na escritura.

2. A menina da cadeira de ródas apresenta-se em 2 versões. A acima registra foi considerada versão B pela pesquisa, e mostra 2 etapas na escritura: a-a : $_{1}$

a: autógrafo completo;

$\mathrm{a}_{1}$ : rasuras a tinta roxa.

3. A versão A de A menina da cadeira de ródas se apresenta com o título A aleijadinha da cadeira de ródas (V. MA-MOE, 293).

\section{MA-MOE, 294}

SOARES, Camilo

294. Menina-zinha pobre; Revelação; Minha mãe creoula que Deus me deu; poesia (MAm)

[Cataguases], s/ data

Datiloscrito original: f. 1-2: fita azul, f. 3: fita vermelha; papel branco; 3 folhas; f. 1: 22,6 x 14,8/14,9 cm, f. $2: 23,1$ x 16,0/16,2 cm, f. $3: 22,9 / 23,2$ x 15,9/16,1 cm; f. 1,3 : bordas esquerda e inferior cortadas; f. 2: bordas esquerda e superior cortadas; pequenos rasgamentos na borda direita superior; vincos; sinais de fungo; escrita no anverso; autoria no final de cada poema: "Camillo Soares"; rasuras a máquina, a tinta roxa; fólio numerado pela pesquisa: (1).

Menina-zinha pobre:

Dedicatória: "ao Ribeiro Couto".

Nota MA: a lápis preto: sugestão de alteração.

Notas da pesquisa:

1. Ms naMário de Andrade mentor.

2. Camilo Soares teve um único livro de poemas publicado: $O$ soldado Nicolau (ed. cit.). 
Estudo genético:

1. O ms apresenta-se em uma única versão, $A$, que mostra 3 etapas de escrita: $a-a_{1}-a_{2}$ : a: datiloscrito completo;

$\mathrm{a}_{1}$ : rasuras a máquina;

$\mathrm{a}_{2}$ : rasuras a tinta roxa.

MA-MOE, 295

SOARES, Camilo

295. Urubú velho; "O dia coloca"; "O vento faz"; poesia (MAm)

[Cataguases], s/ data

Autógrafo a tinta roxa; título em autógrafo a tinta preta; papel branco, impresso na margem superior: ilustração a quatro cores; 1 folha; 27,7 x 21,7 cm; vincos; sinais de fungo; escrita no anverso e no verso; assinatura: após o final do poema: "Camillo."; fólio numerado pela pesquisa: (1).

Urubú velho:

Nota CS a tinta roxa na margem inferior indicando que o poema continua no verso da folha: "vira o troço".

Nota MA a lápis preto no último verso do poema: sugestão de supressão da última palavra do poema: "tirar o tristes".

Notas da pesquisa:

1. Ms naMário de Andrade mentor.

2. Camilo Soares teve um único livro de poemas publicado: O soldado Nicolau (ed. cit.).

Estudo genético:

1. O ms apresenta-se em uma única versão, A, que mostra em "O dia coloca" e "O vento faz" 1 etapa na escritura, e em Urubú velho 2 prováveis etapas na escritura: a-a $a_{1}$ : $\mathrm{a}_{1}-\mathrm{a}_{2}$ : autógrafo a tinta roxa e autógrafo a tinta preta.

\section{MA-MOE, 296}

TELTSCHER, Ignez

296. Mário de Andrade; biografia (MAm)

[Resende], s/ data

Autógrafo a tinta preta; papel branco, pautado; 6 folhas; 32,7 x 20,8/20,9 cm, com variação em mm na largura; f. 1-5: borda direita recortada; f. 6: borda esquerda cortada; f. 1: pequeno rasgamento na borda superior; f. 6: rasgamentos e amassados nas bordas laterais; vincos; sinais de fungo; manchas de tinta no verso; escrita no anverso; folhas numeradas pela escritora: 1-6; rasuras a tinta preta; fólios numerados pela pesquisa: (1)-(6). 
Notas da pesquisa:

1. Ms na vertente Mário de Andrade mentor.

2. Na biblioteca MA há dois livros de Ignez Teltscher: Alma nossa : trechos brasileiros traduzidos para o allemao e Von der brasilianischen seele

\section{Estudo genético:}

1. O ms apresenta-se em uma única versão, $A$, que mostra 2 etapas na escritura: $a-a_{1}$ : a: autógrafo completo;

$\mathrm{a}_{1}$ : rasuras a tinta preta.

\section{MA-MOE, 297}

\section{[VIEIRA], Gastão}

297. Receita de tacacá; receita (MAc)

[Belém, ant. nov. 1933]

Ms no corpo de fragmento de carta [a MA], s/ data; assinatura: "Gastão"; s/ forma de tratamento; autógrafo a tinta preta; papel branco, pautado no anverso, filigrana; 2 folhas; $28,1 \times 21,0 / 21,2 \mathrm{~cm}$; irregularidades na borda superior; $\mathrm{f}$. 1: dois rasgamentos nas bordas superior e inferior; vincos; sinais de fungo; folhas numeradas pelo escritor: 7-8; escrita no anverso; fólios numerados pela pesquisa: (1)-(2).

Nota MA a lápis vermelho: f. 1: grifo em: "A receita do tacacá".

(Ref. cruzada: série Correspondência Mário de Andrade - sub-série Correspondência passiva; MA-C-CPMVA, $\mathrm{n}^{\circ}$ 6945).

\section{Notas da pesquisa:}

1. Ms na vertente Mário de Andrade colecionador.

2. No catálogo Correspondência de Mário de Andrade a data do fragmento da carta foi suposta como anterior a novembro de 1933 no endereço que ela apresenta: "S. Jeronymo 155". Em carta a MA, de 15 de novembro de 1933, GV acusa a mudança do número de sua casa para "695".

3. MA conheceu GV em sua primeira viagem à região Norte do Brasil. No livro Turista aprendiz, nos relatos dos dias 26 e 27 de maio, faz referência a Gastão Vieira.

Estudo genético:

1. O ms apresenta-se me uma única versão, A, que mostra 1 etapa na escritura. 
lepon un-the hi couta dus reportayem.

drucita do tacacá, qu me nanda pedir é a sefuinte.

Ty-se a fornoma de amido; on 1 apróa, a qual pe Gimin s lie necestario.

6 incupy í impando con pol, canasos secor é jambi. É sendo en an as ond se dita una 4 coeteres derfoma

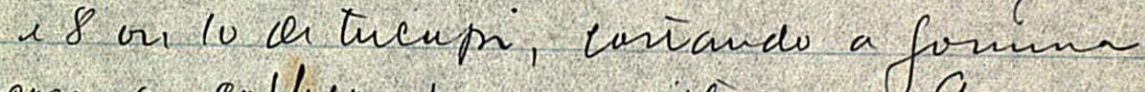
om a quther, pan micurar. Luem grota, adiciona pínentó d cherio no incupr.

lvei sabe ofue étucupy, cono è fabur ado e o jue i jambí

idtrface assin, como i pronvel, suas pusadas brens.

Ve houru ahi ueguma pateicacas sobs radir, semonana, diana on mensal, mas de me pu obegivo. Na "Folda do Nort manienho una seceas dori:-

mal potue iss. Man de me seus inabach secupse, sobeinde Chronicar de alle e wbtenta ahi se houver, un 


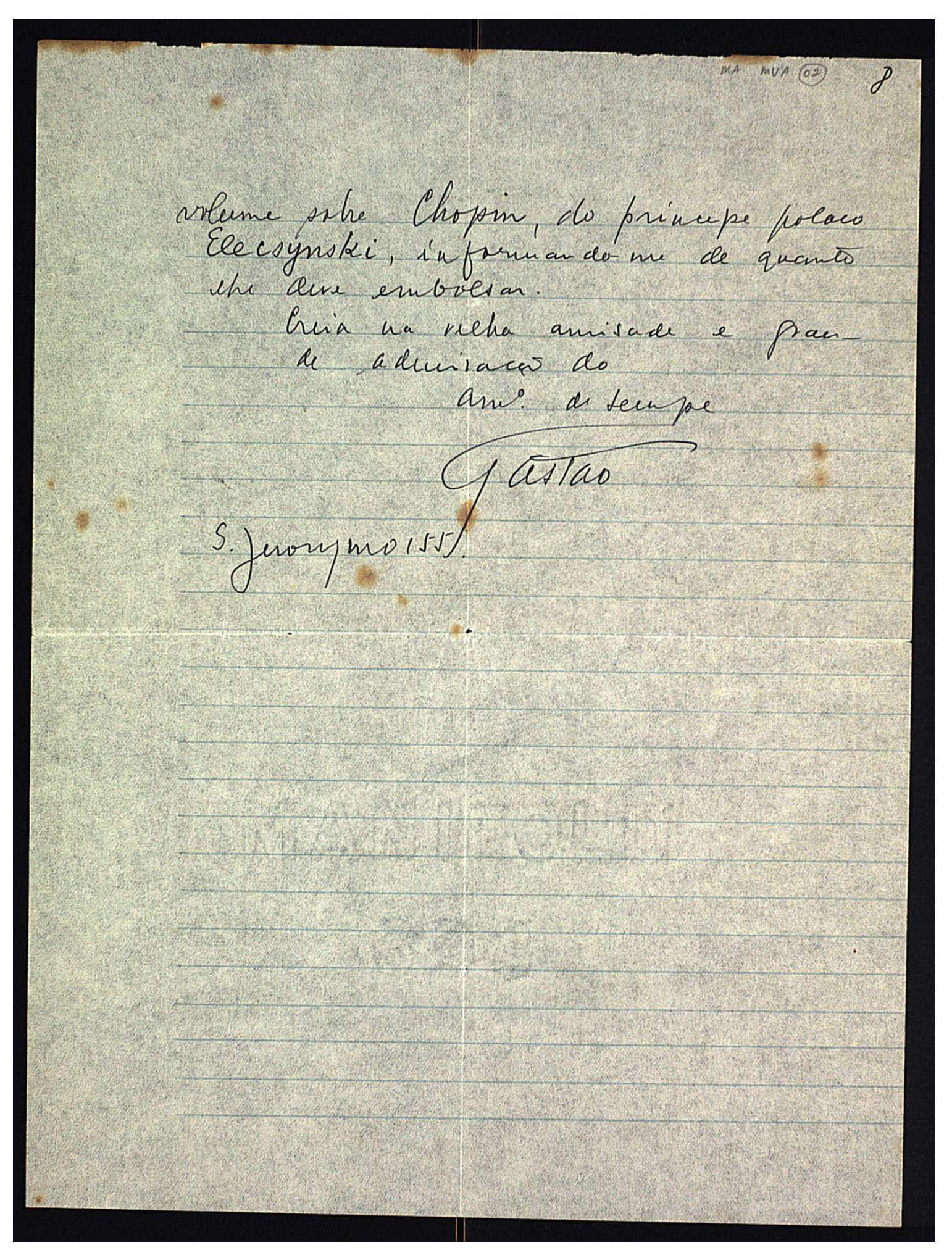


SÉRIE MANUSCRITOS DE OUTROS ESCRITORES - MOE ARQUIVO MÁRIO DE ANDRADE - IEB - USP

ESCRITORES ESTRANGEIROS 
MA-MOE, 298

ANSELMO, Manuel (1911-?)

298. A poesia de Jorge de Lima; crítica (MAc)

Lagos/Porto (Portugal, 1938/1939

Datiloscrito, cópia carbono roxo; datiloscrito original, fita vermelha; autógrafo a tinta azul; autógrafo a tinta preta: f. 1; papel branco, filigrana: "ALMAÇO": f. 1; 118 folhas; $22,5 \times 17,0 \mathrm{~cm}$, com variações em mm; bordas recortadas; f. 14: pedaço de folha colada; vincos; sinais de fungo; manchas de carbono; marcas de impressão de dedos; folhas numeradas a lápis: $3-4,124$, a tinta azul: 5-6, 15, 59, 61, 64-66, 70 e a máquina: 9-14, 16-26, 28-58, 60, 63, 67-69, 71-83, 85-103, 105-123; escrita no anverso; f. 1: folha de rosto com autoria, título, editora, local e data: "Manuel Anselmo", "A poesia de | Jorge de Lima", Livraria Civilização Editora | Porto 1939"; f. 2: dedicatória: "A | A FERREIRA DE CASTRO"; f. 3-4: dedicatória a Ferreira de Castro, com local, data e assinatura a máquina, na f. 4: "Lagos, Natal de 1938" | Lagos, Setembro de 1938, "MANUEL ANSELMO."; cabeçalho nas páginas pares: "A POESIA DE JORGE DE LIMA", autoria no cabeçalho das páginas ímpares: "MANUEL ANSELMO", com exceção das folhas: 1-6, 22, 57, 77, 97, 117-118; rasuras a máquina, a tinta azul, a tinta preta, a lápis tinta, a lápis preto; fólios numerados pela pesquisa: (1)-(1) (1) (8). Notas a lápis azul vermelho destacando trechos.

Notas da pesquisa:

1. Ms na vertente Mário de Andrade colecionador.

2. O ms acima registrado mostra-se em fase final de preparo para a edição em livro.

3. No início da dedicatória a Meu caro Ferreira de Castro, na f. 3, se lê: "Meu caro Ferreira de Castro: | Não encontro outro escritor que, | pelo seu talento, caracter da sua obra e tendência intelectual, mere- | ça, mais do que Você, a dedicatória deste livro de análise demorada | e ampla a um dos maiores poetas de todos os tempos do Brazil."

4. Otávio de Faria mantinha correspondência com MA e MAns, podendo sido ele quem encaminou o ms a MA.

5. O livro A poesia de Jorge de Lima foi publicado em 1939.

Estudo genético:

1. O ms apresenta-se em uma única versão, A, que mostra diferentes etapas na escritura a serem tratadas de forma detida em trabalho específico.

2. A pesquisa não identificou a autoria das Notas a lápis azul e vermelho, podendo ser do escritor ou de MA. 
MA - MOE, 299

CHANTEPLEURE, Guy (1875-?)

299. Ça m'botte; Elegance masculina; Metrique syncopatique; "Samedi, jour barbier,"; poesia (MAc)

[França ?], s/ data

Autógrafo a tinta preta; papel branco, pautado no anverso; 4 folhas; 27,7 x 21,0 cm; vincos; sinais de fungo; f. 1: rasgamento no canto superior direito; escrita no anverso; rasuras a tinta preta; f. 4: 2 desenhos a tinta preta; fólios numerados pela pesquisa: (1)(4). NotaGC.

Ça m'botte:

Dedicatória: “A Yean Rictus | poète de malheur". Nota GC abaixo do título: "Frangine R. du Mont Cenis | Rrrepublique de Montmartre | (arrière cour) | adressez vous au pipelet s. v. p".

Metrique syncopatique:

Dedicatória: "ao Mario Andrade e aos poetas | que elle prefere.".

Notas da pesquisa:

1. Ms na vertente Mário de Andrade colecionador.

2. Na série Correspondência Mário de Andrade, no IEB-USP, não há correpsondência que comprove o envio do ms.

Estudo genético:

1. O ms apresenta-se em uma única versão, A, que mostra em Os poemas Ça m'botte 1 etapa na escritura, e em Elegance masculina, Metrique syncopatique e "Samedi, jour barbier," 2 etapas na escritura: a-a $a_{1}$ :

a: autógrafo completo.

$\mathrm{a}_{2}$ : rasuras e desenhos a tinta preta.

MA - MOE, 300

FINGERIT, Marcos (1904-1979)

300. Automovil; Antena; Profecia; Amarra tensa; Josefina Baker; poesia (MAd)

[La Plata, Argentina, ant. 9 nov.] 1927

Datiloscrito, cópia carbono roxo; papel branco; filigrana: "Libertad extra strong"; 9 folhas; $21,3 \times 14 \mathrm{~cm}$, com variações em mm; vincos; sinais de fungo; escrita no anverso; f. 9: nome, local, ano e assinatura: "Marcos Fingerit. | Republica Argentina.1927.- | Marcos Fingerit"; folhas numeradas pelo escritor: 1-3; rasuras a máquina e a lápis vermelho; fólios numerados pela pesquisa: (1)-(3). (MAde)

Automovil:

Dedicatória: “A Mario de Andrade." 
Notas da pesquisa:

1. Ms na vertente Mário de Andrade no diálogo interpares.

2. O ms é enviado a MA junto da carta de La Plata, 9 novembro de 1927, na qual o poeta argentino relata: "dentro de pocos dias daré a publicidad un nuevo | libro, llamado 'Antena: veintiun poemas contempora- |neos', [...] le envio a usted algunos de sus poemas, como | antecipo del libro que me apresuraré a enviarle | en cuanto aparezca. Esos poemas puede usted hacer- | los publicar donde guste, y yo le quedaré nuevamen- | te obligado." (Arquivo Mário de Andrade, sub-série Correspondência passiva, MA-CCPL, n 3073 )

3. Atendendo ao pedido de MF, para divulgação de seus poemas, MA enviou Josefina Baker ao jovem escritor Rosário Fusco, um dos diretores da revista Verde, do modernismo mineiro. Sua publicação acontece no $\mathrm{n}^{\text {o }} 4$, dez. 1927, p. 8. Abaixo do poema, na mesma página, além da referência: "(Do livro inedito Antena)", há uma nota sobre o autor, que possivelmente foi elaborada pelo próprio MA: "Poeta da moderna geração argentina, com | 23 anos, Marcos Fingerit com as Canciones Mi- | nimas, alcançou um posto singular na literatura | viva da Argentina. Diante do tumulto espaven- $\mid$ tado da epoca moderna de primeiro a mocida- $\mid$ de dêle reagiu. O moço se voltou e se protegeu. | Provêm d'aí as Canciones Minimas, livro de lar, | delicioso, duma doçura excepicional. Agora, mais | fortificado êle se pôs respirando a vida moderna $\mid$ das ruas. Surgiu então o livro Antena, já no $\mid$ prélo e que trará ilustrações do universalmente $\mid$ conhecido pintor moderno argentino, Pettoruti. $\mid\langle<$ Verde $\rangle>$ se sente feliz de unir ao canto brasileiro uma nota pura da Argentina.".

4. Na carta de Rosário Fusco a MA, de Cataguases, 4 de janeiro de 1928, está a informação a respeito da publicação de "Josefina Baker" na revista Verde, e ao lado a Nota MA: "Verde 4 | para Marcos Fingerit" (Arquivo Mário de Andrade, sub-série Correspondência passiva, MA-C-CPL, $\mathrm{n}^{\circ}$ 3247).

5. Os poemas no ms foram publicados em Antena: 22 poemas contemporaneos (Buenos Aires, Editorial Tor, 1929). Na biblioteca MA encontra-se um exemplar com dedicatória na folha de ante-rosto: "A | Mario de Andrade, | ratificación de | cordialisima simpa- $\mid$ tia y profunda | admiración. | Marcos Fingerit | Mc.: Calle 3 n¹048 - La Plata - Rep. Arg.".

6. Sobre Antena: 22 poemas contemporaneos (ed. cit.), MA nada publicou.

7. O envio do ms de MF se liga ao momento em que intelectuais de alguns países da América do Sul, como Argentina, Uruguai e Peru, buscavam entre eles e com o Brasil, o que se pode chamar de um intercâmbio cultural. Na segunda metade da década de 1920 MA mostra seu interesse pela expressão cultural dos países vizinhos em artigos seus publicados em jornais e na revista Terra roxa e outras terras. Nesse período, alguns escritores vêem em MA uma espécie de intermédio para a divulgação de sua literatura entre os jovens escritores de expressão dentro do movimento modernista brasileiro. (Sobre esse assunto v. ARTUNDO, Patricia Maria. Mário de Andrade y la Argentina. Tese de Doutoramento, São Paulo, Universidade de São Paulo, 2001, tomos I e II)

8. O primeiro contato de MF com MA foi por meio de indicação do artista plástico argentino Emilio Pettoruti, aconteceu com o envio, junto à carta datada de 3 jun. 1927, do livro FINGERIT, Marcos. Canciones mínimas y nocturnos de hogar. Buenos Aires, Editorial Tor, 1926. É o início de um escasso carteamento entre os dois escritores. (Arquivo Mário de Andrade, sub-série Correspondência passiva, MA-C-CPL, nº 3072) 
9. Há um exemplar desse livro na biblioteca Mário de Andrade com dedicatória: "A | Mario de Andrade, | caluroso homenaje de cor- | dial admiración. | Marcos Fingerit | Mi casa: 8 n $^{\circ}$ 584.- La Plata.- Rep. Argentina".

10. Durante a segunda metade da década de 1920, MA tem publicados os seguintes textos seus sobre literatura argentina: "Salas Subirat: La Ruta del Miraje, 1924; Pasos en la Sombra, 1926; Marinetti, 1926." (Terra roxa e outras terras, São Paulo, a. 1, n 7, 17 set. 1926); "Poesia Argentina" (Diário Nacional, domingo, 30 out. 1927); "Literatura modernista argentina I" (Diário Nacional, domingo, 22 abr. 1928); "Literatura modernista argentina II" (Diário Nacional, domingo, 29 abr. 1928); "Literatura modernista argentina III" (Diário Nacional, domingo, 13 maio 1928); "Literatura moderna argentina" (Diário Nacional, domingo, 20 maio 1928).

11. Em "Literatura modernista argentina III", entre outros nomes argentinos e sua produção cultural MA escreve sobre Marcos Fingerit e suas Canciones mínimas y nocturnos de hogar.

Estudo genético:

1. O ms apresenta-se em uma única versão, $A$, que mostra duas etapas na escritura: a-a $a_{1}$ : a: datiloscrito completo;

$\mathrm{a}_{1}$ : rasuras a máquina.

2. Versão A confrontada com a versão B em Antena: 22 poemas contemporaneos (ed. cit.), exibe variantes.

MA - MOE, 301

GOLL, Ivan (1891-1950)

301. Absolument; poesia (MAc)

[Paris], s/ data

Datiloscrito, cópia carbono azul; papel branco; 1 folha; 27,1 x 21,1 cm; 1 rasgamento na borda direita; pequenos rasgamentos nas bordas superior e inferior; vincos; sinais de fungo; escrita no anverso; assinatura a tinta azul: "Ivan Goll"; rasuras a tinta azul; fólio numerado pela pesquisa: (1).

Notas da pesquisa:

1. Ms na vertente Mário de Andrade colecionador.

2. Na série Correspondência Mário de Andrade, no IEB-USP, há apenas uma carta de IG a MA, de Paris em 29 de junho de 1923, na qual o remetente pede autorização para traduzir poemas do destinatário, mas não comenta envio de ms.

3. Sérgio Milliet foi uma espécie de intermediário entre MA e IG: em carta de 6 de junho de 1923 MA escreve: "Ivan Goll de paris Brennt é um bicho. Pergunta-lhe se uma tradução do poema para o português é coisa que ele me permite. Manda-me a direção dele”. (DUARTE, Paulo. Mário de Andrade por ele mesmo. São Paulo, EDART, 1971, p. 290). Há várias menções a IG na correspondência trocada entre MA e Sérgio Milliet.

4. MA conservou um único livro de IG em sua biblioteca: Cinq continents anthologie mondiale de poesie contemporaine... (Paris : La Renaissance du Livre, 1922). 
Estudo genético:

1. O ms apresenta-se em uma única versão, A, que mostra 2 etapas na escritura: a-a $a_{1}$ : a: datiloscrito completo;

$\mathrm{a}_{1}$ : rasuras a tinta.

MA-MOE, 302

GRAIVER, Bernardo (1902-1983)

302. Versos: Lunaris; Arenas de oro; Eres; Puerta; Madrigal; poesia (MAd)

[La Plata, 1927/1928]

Autógrafo a tinta azul; papel branco, pautado; 1 folha; 17,7 x 22,8 cm; vincos; sinais de fungo; escrita no anverso; dedicatória: "( A mi amigo el poeta M. Andrade)"; rasuras a tinta azul; fólio numerado pela pesquisa: (1).

Nota MA a lápis preto na margem inferior: “(B. Graiver)”.

Notas da pesquisa:

1. Ms na vertente Mário de Andrade no diálogo interpares.

2. BG enviou o ms a MA junto de carta, de la Plata sem mês, em 1927, na qual se lê: "[...] guste recibir por ahora estos versos que los dedico a ud, como acto de agradecimiento por su gentileza, y como mi puente en el aire tendido hacia los poetas del pais hermano". (Ref.: série Correspondência Mário de Andrade; sub-série Correspondência passiva: MA-C-CPL, $\mathrm{n}^{\circ}$ 3522)

3. Na biblioteca Mário de Andrade não consta livro com os poemas no ms publicados.

4. Em 1927 envia junto com carta duas séries de poemas dos quais pede opinião para Mário. Exemplar na biblioteca Mário de Andrade, no IEB.

5. Acompanhando a missiva de 01 março de 1927 BG presenteou MA com duas séries de poemas publicados: 20 poemas de Bernardo Graiver [produção independente: B. Graiver - 8 N. 387 - La Plata - Rep. Argentina]

Estudo genético:

1. O ms apresenta-se em uma única versão, A, que mostra 1 etapa na escritura.

\section{MA-MOE, 303}

GUILLÉN, Alberto (1900-1935)

303. Guijarros; poesia (MAd)

[Lima, Peru], s/ data

Datiloscrito original, fita preta; título em autógrafo a tinta azul; papel branco; 1 folha; 20,3 x 14,0 cm; rasgamento na borda esquerda; vinco; sinais de fungo; escrita no anverso; dedicatória: "A Mario Andrade"; assinatura a tinta azul: "Alberto Guillén"; fólio numerado pela pesquisa: (1).

Nota MA a lápis preto no verso: "Guillen". 
Notas da pesquisa:

1. Ms na vertente Mário de Andrade e o diálogo interpares.

2. Na série correspondência Mário de Andrade, no IEB-USP, não constam menção de envio do Ms na s cartas de AlbG.

Estudo genético:

1. O ms apresenta-se em uma única versão, A, que mostra 1 etapa na escritura.

\section{MA-MOE, 304}

\section{HORIGOUTCHI, Nico D.}

304. La poésie japonaise contemporaine; crítica (MAc)

Rio de Janeiro, 29 mar. 1922

Datiloscrito, cópia carbono azul; papel branco; 2 folhas; 27,9/28,0 x 21,6/21,7 cm; vincos; sinais de funco; margem superior amassada; escrita no anverso; f. 2: data: "Rio de Janeiro, le 29 mars 1922." e assinatura a tinta preta: "Nico D. Horigoutchi"; rasuras a tinta preta; fólios numerados pela pesquisa: (1)-(2).

Notas da pesquisa:

1. Ms na vertente Mário de Andrade colecionador.

2. Não há carta de NH na série Correspondência Mário de Andrade, no IEB-USP, nem livro seu guardado por MA.

3. Em 1921, NH publicou Petits poèmes japonais (Paris, éditions du Fauconnier). Exemplar na Biblioteca Nacional de Paris.

Estudo genético:

1. O ms apresenta-se em uma única versão, A, que mostra 2 etapas na escritura: a-a ${ }_{1}$ : a: datiloscrito completo;

$\mathrm{a}_{1}$ : rasuras a tinta preta.

\section{MA-MOE, 305}

\section{HORIGOUTCHI, Nico D.}

305. Haikais Japonezes; poesia (MAc)

S/ local, s/ data

Datiloscrito original, fita vermelha; papel branco, filigrana; 7 folhas; $28,1 \times 21,8 \mathrm{~cm}$; vinco; sinais de fungo; f. 1: mancha de tinta preta na margem direita; escrita no anverso; folhas numeradas pelo escritor: 2-7; fólios numerados pela pesquisa: (1)-(7).

Nota NH: Fin de l'automne

Notas da pesquisa:

1. Ms na vertente Mário de Andrade colecionador. 
2. No ms hai-kais japoneses traduzidos para o francês, a maioria deles com indicação da autoria: "N'était la voix" (Sokan, 1465-1554); "Un pétale tombé" (Arakida Moritake, 1472-1549); "De ma douche"; Dans la haie," (Nishiyama Soïn); "Au moindre vent" (École de Senryu); "Simplement" (Buson); "Plein de souvenirs," (Buson); "J'arrive fatigué" (Bashô); "Une chaumiére de montagne." (Kikwan); "Dans le soleil tremblant," (Buson); "Un bateau et son filet" (Buson); "Pas une lumière." (Buson); "Tout d'un coup," (Onitsura, 1661-1738); "Personne n'ouvre sa porte"; "Quel remue-ménage!" (Kyorai, 1651-1714); "Pluie un jour de printemps." (Buson); "Appel au passeur." (Buson); "Pèlerins en route." (Isshû); "Neige dans la basse-cour" (Ransetsu, 16541707); "Longue, longue," (École de Bashô); "Lorsque deux ou trois nuages" (Bashô); "Une lune pluvieuse" (Etsujin); "Tout le monde" (Teitoku 1571-1653); "Pleine lune." (Bashô); "Le cavalier" (Kyorai); "Commencement de l'automne." (Buson); "Chut! Écoutez" (Kikaku); "Près de sa coque abandonnée" (Jôsô); "Un cimetière." (École de Kikaku); "Crépuscule." (Kyoraï); "Feu sous la cendre." (Buson); "Teinte uniforme." (Yasui); ““'C'est l'été qui m'a fait maigrir!'” (Kikin); "Comme les feuilles sur l'étang," (Buson); "Un matelas de papier" (Buson); "Épouvantement..." (Buson); "Elles s'épanouissent, -alors" (Onitsura); "Ce "monde de rosée"”" (Issa, 1763-1827); "Une vielle mare," (Bashô); "Sur une branche nue" (Bashô); "Sur la fleur où elle joue," (Bashô); "La libellule rouge," (Kikaku); "Un grain de piment rouge," (Bashô); "Que je veille" (Chiyo).

Estudo genético:

1. O ms apresenta-se em uma única versão, A, que mostra 1 etapa na escritura.

\section{MA - MOE, 306}

HUMMEL, Alexandre (Arald Alexander Hummel, 1844-1913)

306. História de Jacintho, o pequeno cesteiro; conto infantil (MAc)

[Tietê, SP, ant. ago. 1913]

Apógrafo de Herculano da Silveira; autógrafo a tinta preta; caderno brochura; capa estampada em verde e beje; 23,3 x 16,0 cm; capa e quarta-capa amassadas; cantos desgastados; sinais de fungo; rasgamento na borda inferior da capa, mancha de tinta vermelha; miolo: papel branco, pautado; 47 folhas; $23,3 \mathrm{x} 16,0 \mathrm{~cm}$; cantos desgastados; sinais de fungo; f. 1: etiqueta de identificação na biblioteca MA: C/II/d/174; f. 1-4, 26-30, 37-43, 45: mancha de tinta azul na borda inferior; f. 4: 1 rasgamento na borda inferior esquerda; numeração das folhas borrada; entre f. 29 e f. 30: sinal que 1 folha foi arrancada; escrita no anverso; folhas numeradas a tinta preta: 1-35; rasuras a tinta preta; fólios numerados pela pesquisa: (1)-(4) (9).

Notas MA: autógrafo a tinta preta: indicação de título e autoria: "Historia | de Jacinto, | o pequeno cesteiro, | por Alexandre | Hummel."; a lápis preto: f. 1: margem inferior: "Uma cópia deste conto, fei- | ta em tiras, foi dada | ao Lyceu dos Salesianos, | em 1918, por Herculano da | Silveira, para ser publicada": sobre a nota, rasura: cruzes a lápis preto, substituindo a informação por outra nota a lápis preto na margem esquerda: "Posso fazer um prefacio biographico, | e talves possa fornecer o cli-ché do | autor-Herculano-", f. 7, 8, 17, 19-20, 32: marcações às margens. 


\begin{abstract}
Anexo:
O ms está acompanhado do prefácio Duas palavras, de Herculano da Silveira: [post. ago. 1913]; autógrafo a tinta preta; papel branco, pautado no anverso, filigrana; 3 folhas; 28,0 x 21,8 cm; f. 1: irregularidades na borda direita superior, 1 rasgamento na borda esquerda inferior; vincos; sinais de fungo; escrita no anverso; f. 3: assinatura: "Herculano da Silveira."; folhas numeradas pelo escritor: 2-3; rasuras a tinta preta; fólios numerados pela pesquisa: (1)-(3).
\end{abstract}

Notas da pesquisa:

1. Ms na vertente Mário de Andrade colecionador.

2. Arald Alexander Hummel nasceu em Copenhage, Dianamarca, em março de 1884. Mudou-se para o Brasil aos 23 anos; viveu em algumas cidades do interior paulista, mas foi em Tietê, estado de São Paulo, que fixou residência, por mais de 30 anos, até sua morte. Trabalhava como professor de crianças além de se dedicar a pesquisas sobre gramática da língua portuguesa e ciências naturais.

3. A introdução História de Jacintho, o pequeno cesteiro, conto de literatura infantil, traz as informações do autor sobre a elaboração: "Nota. A talagarça sobre que foi bordada esta história, é um pequeno conto de igual nome, que muitos dos meus jovens leitores devem conhecer do segundo livro de Abílio. § Costumo ditar tais contos aos meus alunos discípulos, e à medida que vou ditando, vou improvisando maior desenvolvimento ao assunto que assim passa às vezes por uma transformação completa. Foi assim que originou-se também a presente história" (ms f. 1). O "segundo livro de Abílio" trata de uma espécie de cartilha de autoria do educador baiano Abílio Cesar Borges, responsável pela formação de personalidades como Castro Alves e Rui Barbosa, e que, em 1881, recebeu o título de Barão de Macaúbas, concedido por D. Pedro II, por sua atuação.

4. Herculano da Silveira, educador e amigo de AH, redigiu o apógrafo com a licença do autor antes de sua morte; após o falecimento de $\mathrm{AH}$, elaborou um prefácio, intitulado Duas palavras, o qual acusa um projeto de publicação da História de Jacintho, o pequeno cesteiro, mas que acabou não ocorrendo.

5. A data do ms foi atestada com base nas informações contidas no ms Duas palavras e na data da morte de $\mathrm{AH}$; segundo o prefácio de Herculano da Silveira, a História de Jacintho, o pequeno cesteiro foi copiada por seu próprio punho antes da morte do autor do conto para crianças.

6. Não foi possível identificar a data nem a forma como o ms chegou às mãos de MA. Porém, a caligrafia das Notas MA na primeira folha do caderno da História de Jacintho, o pequeno cesteiro indicam seu registro ainda na juventude.

7. A etiqueta colada por MA na primeira folha do caderno, comprova que o caderno não fora guardado junto aos demais ms de outros escritores, mas junto com os livros em sua biblioteca.

Estudo genético:

1. O ms apresenta-se em uma única versão, A, que mostra 2 etapas na escritura: a-a $a_{1}$ :

a: autógrafo completo;

$\mathrm{a}_{1}$ : rasuras a tinta preta. 
ÍNDICE DOS NOMES

NA SÉRIE MANUSCRITOS DE OUTROS ESCRITORES

ARQUIVO MÁRIO DE ANDRADE

\begin{tabular}{|c|c|c|c|}
\hline ESCRITORES BRASILEIROS & ABREVIATURA & NÚMERO & PÁGINAS \\
\hline 01. ABREU, Rodrigues de & RoA & MA-MOE, 01 & 26 \\
\hline 02. ACCIOLI, João & $\mathrm{JAc}$ & MA-MOE, 02 & 27 \\
\hline \multirow[t]{2}{*}{ 03. ACCIOLY, Breno Rocha } & $\mathrm{BA}$ & MA-MOE, 03-08 & 33 \\
\hline & & MA-MOE, 09 & 35 \\
\hline \multirow[t]{11}{*}{ 04. ALMEIDA, Fernando Mendes de } & FeMA & MA-MOE, 10 & 37 \\
\hline & & MA-MOE, 11 & 37 \\
\hline & & MA-MOE, 12 & 38 \\
\hline & & MA-MOE, 13 & 42 \\
\hline & & MA-MOE, 14 & 43 \\
\hline & & MA-MOE, 15 & 43 \\
\hline & & MA-MOE, 16 & 44 \\
\hline & & MA-MOE, 17 & 45 \\
\hline & & MA-MOE, 18 & 47 \\
\hline & & MA-MOE, 19 & 48 \\
\hline & & MA-MOE, 20 & 49 \\
\hline \multirow[t]{2}{*}{ 05. ALMEIDA, Francisco Martins de } & FrMA & MA-MOE, 21 & 51 \\
\hline & & MA-MOE, 22 & 52 \\
\hline 06. ALMEIDA, Renato & $\operatorname{ReA}$ & MA-MOE, 23 & 53 \\
\hline \multirow[t]{3}{*}{ 07. ALMEIDA, Tácito de } & $\mathrm{TA}$ & MA-MOE, 24 & 54 \\
\hline & & MA-MOE, 25 & 55 \\
\hline & & MA-MOE, 26 & 55 \\
\hline 08. ALPHONSUS, João & JAlp & MA-MOE, 27 & 56 \\
\hline \multirow[t]{4}{*}{ 09. ALVARENGA, Oneida } & $\mathrm{OA}$ & MA-MOE, 28-30 & 57 \\
\hline & & MA-MOE, 31 & 64 \\
\hline & & MA-MOE, 32 & 70 \\
\hline & & MA-MOE, 33 & 70 \\
\hline
\end{tabular}


10. ANDRADE, Carlos Augusto de

11. ANDRADE, Carlos Drummond de

12. ARANHA, Luís

13. AUTO, José

14. BANDEIRA, Manuel
CAA

LA

$\mathrm{JAu}$

MB
MA-MOE, 34

MA-MOE, 35

MA-MOE, 36

MA-MOE, 37

MA-MOE, 38

MA-MOE, 39

MA-MOE, 40

MA-MOE, 41

MA-MOE, 42

MA-MOE, 43

MA-MOE, 44

MA-MOE, 45

MA-MOE, 46

MA-MOE, 47-61

MA-MOE, 62

MA-MOE, 63

MA-MOE, 64

MA-MOE, 65-66

MA-MOE, 67

MA-MOE, 68

MA-MOE, 69

MA-MOE, 70

MA-MOE, 71

MA-MOE, 72

MA-MOE, 73

MA-MOE, 74

MA-MOE, 75

MA-MOE, 76

MA-MOE, 77

MA-MOE, 78

MA-MOE, 79
71

72

72

73

74

75

77

80

81

81

82

83

83

88

91

92

93

93

95

96

99

100

103

103

104

105

109

110

110

111

113 
MA-MOE, 80

MA-MOE, 81

MA-MOE, 82

MA-MOE, 83

MA-MOE, 84

116

MA-MOE, 85

15. BATINI, Tito

TB

MA-MOE, 86

117

16. BOPP, Raul

MA-MOE, 87

118

MA-MOE, 88

119

17. BRISOLA, Ciro

CB

MA-MOE, 89

120

18. BRITO, Mário da Silva

MSB

MA-MOE, 90

121

19. CAMPELO, Samuel

$\mathrm{SC}$

MA-MOE, 91

122

20. CAMPOS, Eduardo

EC

MA-MOE, 92

122

21. CARDOSO, Lúcio

LC

MA-MOE, 93

123

22. CARNEIRO, Cecílio José

CJC

MA-MOE, 94

124

23. CARVALHO, Ronald

$\mathrm{RC}$

MA-MOE, 95

125

MA-MOE, 96

126

MA-MOE, 97

127

24. CASCUDO, Luis da Câmara

LCC

MA-MOE, 98

128

MA-MOE, 99

128

MA-MOE, 100

129

MA-MOE, $101 \quad 130$

25. CASTRO, Arlindo de

$\mathrm{AC}$

MA-MOE, 102-111 130

26. CASTRO, Moacyr Werneck de

MWC

MA-MOE, 112

133

MA-MOE, 113

134

27. CHIARINI, João

JC

MA-MOE, 114

134

MA-MOE, 115

135

28. DAMANTE, Francisco

FD

MA-MOE, 116

136

29. DEL PICCHIA, Paulo Menotti

MDP

MA-MOE, 117

137

30. DUARTE, Paulo

PD

MA-MOE, 118

137 
31. ERISMANN, Georgina de Mello

32. FARIA, Otavio de

33. FERNANDES, Jorge

34. FERREIRA, Ascenso

35. FERREIRA, Stella Gris

36. FIGUEIREDO, Guilherme

37. FIGUEIRÓ

38. FONSECA, Cleodon

39. FREITAS JÚNIOR, Otávio de

40. FUSCO, Rosário
GME

$\mathrm{OF}$

$\mathrm{JF}$

$\mathrm{AF}$

MA-MOE, 128

MA-MOE, 129

MA-MOE, 130

MA-MOE, 131

MA-MOE, 132

MA-MOE, 133

MA-MOE, 134

MA-MOE, 135

MA-MOE, 136

MA-MOE, 137

MA-MOE, 138

MA-MOE, 139

MA-MOE, 140

MA-MOE, 141

MA-MOE, 142

MA-MOE, 143

MA-MOE, 144

MA-MOE, 145

MA-MOE, 146

MA-MOE, 147

MA-MOE, 148

MA-MOE, 149

MA-MOE, 150

MA-MOE, 151

MA-MOE, 152
138

139

140

141

142

143

144

144

146

147

147

148

148

149

149

151

151

153

153

154

155

157

157

158

159

159

160

161

161

162

162 
40. FUSCO, Rosário

RF

MA-MOE, $153 \quad 163$

MA-MOE, 154

MA-MOE, $155 \quad 165$

MA-MOE, 156

MA-MOE, $157 \quad 166$

MA-MOE, $158 \quad 167$

MA-MOE, 159

MA-MOE, $160 \quad 168$

MA-MOE, $161 \quad 169$

MA-MOE, $162 \quad 170$

MA-MOE, $163 \quad 170$

MA-MOE, 164

41. GUARNIERI, Rossini Camargo

RCG

MA-MOE, 165

42. GUIMARAENS, Alphonsus de

AlpG

MA-MOE, 166

172

43. GUIMARAENS, Liliana B. V. de LG

MA-MOE, 167-168 173

44. GUIMARAENS FILHO, Alphonsus de AGF

MA-MOE, 169

MA-MOE, 170

MA-MOE, $171 \quad 176$

MA-MOE, $172 \quad 178$

MA-MOE, $173 \quad 178$

MA-MOE, 174

MA-MOE, $175 \quad 179$

MA-MOE, $176 \quad 180$

MA-MOE, $177 \quad 181$

MA-MOE, $178 \quad 182$

MA-MOE, $179 \quad 183$

MA-MOE, 180

MA-MOE, 181

45. GUIMARÃES, Rute

MA-MOE, $182 \quad 184$

46. IVO, Ledo

LI

MA-MOE, 183

185 
47. LACERDA, Carlos

47. LACERDA, Carlos

48. LESSA, Orígenes

49. LIMA, Cláudio de Araújo

50. LIMA, Jorge de

51. LIRA, Mariza

52. LISBOA, Henriqueta

53. LOPES, Ascânio

54. MACHADO, Alcântara

55. MACHADO, Anísio

56. MACHADO, Leão

57. Maria da Glória e outros

58. MEDEIROS, Aluízio

59. MEIRELES, Cecília

60. MENDES, Murilo
CL

MA-MOE, 184

187

MA-MOE, 185

189

CL

MA-MOE, 186

189

MA-MOE, 187

190

OL

MA-MOE, 188

191

CAL

MA-MOE, 189

192

JL

MA-MOE, 190

192

ML

MA-MOE, 191

193

MA-MOE, 192

194

HL

MA-MOE, 193

194

MA-MOE, 194

195

MA-MOE, 195

197

MA-MOE, 196

199

MA-MOE, 197

200

MA-MOE, 198

201

MA-MOE, 199

201

MA-MOE, 200

202

AL

MA-MOE, 201

203

AM

AníM

MA-MOE, 202-203 204

MA-MOE, $204 \quad 205$

MA-MOE, $205 \quad 208$

MA-MOE, $206 \quad 209$

LM

MA-MOE, 207

210

MA-MOE, $208 \quad 211$

AlM

MA-MOE, 209

212

MA-MOE, 210

213

MA-MOE, 211

214

MA-MOE, 212

217

MA-MOE, 213

218

MA-MOE, 214

218

MA-MOE, 215 
60. MENDES, Murilo

61. MEYER, Augusto

62. MILANO, Dante

63. MILLIET, Sérgio

64. MIRANDA, Murilo

65. MIRANDA, Nicanor

66. MORAES, Aldo

67. MORAIS NETO, Prudente de

68. MOURA, Nídia

69. NAVA, Pedro

\author{
MuMe \\ AuM \\ DM
}

SM

NMi

AdM

PMN

NMo

PN
MA-MOE, 216

219

MA-MOE, 217

221

MA-MOE, 218

221

MA-MOE, 219

222

MA-MOE, 220

223

MA-MOE, 221

224

MA-MOE, 222

224

MA-MOE, 223

225

MA-MOE, 224

225

MA-MOE, 225

226

MA-MOE, 226

227

MA-MOE, 227

228

MA-MOE, 228

229

MA-MOE, 229

230

MA-MOE, 230

231

MA-MOE, 231

232

MA-MOE, 232-238 232

MA-MOE, 239

234

MA-MOE, 240

235

MA-MOE, 241

236

MA-MOE, 242

236

MA-MOE, 243

237

MA-MOE, $244 \quad 238$

MA-MOE, $245 \quad 238$

MA-MOE, 246-247 239

MA-MOE, $248 \quad 240$

MA-MOE, 249-250 241

MA-MOE, $251 \quad 242$

MA-MOE, 252-253 242

MA-MOE, 254 
70. OLIVEIRA, Armando de

MA-MOE, 255

71. OLIVEIRA, J. Lourenço de

MA-MOE, 256 244

72. PACHECO, João

MA-MOE, 257-259 245

72. PACHECO, João

MA-MOE, $260 \quad 246$

73. PATERNOSTRO, Júlio

MA-MOE, 261

247

74. PAURILIO, Carlos

MA-MOE, 262

247

75. PEIXOTO, Francisco Inácio

MA-MOE, $263 \quad 248$

MA-MOE, $264 \quad 249$

76. PELEGRINO, Hélio

HP

MA-MOE, $265 \quad 250$

77. PINTO, Lauro

LP

MA-MOE, 266

250

78. QUEIROZ, Raquel de

RQ

MA-MOE, 267

253

MA-MOE, 268

MA-MOE, 269

79. RAMOS, Alberto

AlR

MA-MOE, 270

255

80. RANGEL, Luiz Felipe do Rego

LFR

MA-MOE, 271

256

MA-MOE, 272

257

81. REBELO, Marques

MaR

MA-MOE, 273

257

MA-MOE, 274

258

MA-MOE, 275

259

82. REGO, José Lins do

JLR

MA-MOE, 276

260

83. RESENDE, Henrique

HR

MA-MOE, 277

261

MA-MOE, 278

262

84. RESENDE, Otto Lara

OLR

MA-MOE, 279

263

MA-MOE, $280 \quad 263$

85. RODRIGUES, Augusto

AuR

MA-MOE, $281 \quad 264$

86. ROSA, Roldão Mendes

RMR

MA-MOE, 282

265

87. ROSENDO

Ro

MA-MOE, 283

266

88. RUBIÃO, Murilo

MuR

MA-MOE, $284 \quad 267$

MA-MOE, $285 \quad 268$

MA-MOE, $286 \quad 270$

MA-MOE, 287 


\begin{tabular}{llll} 
90. SANTOS, Virgílio Paula & VPS & MA-MOE, 288 & 271 \\
91. SILVEIRA, Valdomiro & & MA-MOE, 289 & 273 \\
92. SIMÕES, Eduardo Valente & EVS & MA-MOE, 290 & 273 \\
93. SOARES, Camilo & CS & MA-MOE, 291 & 274 \\
& & MA-MOE, 292 & 275 \\
& & MA-MOE, 293 & 276 \\
& & MA-MOE, 294 & 276 \\
94. TELTSCHER, Ignez & & MA-MOE, 295 & 277 \\
95. VIEIRA, Gastão & GV & MA-MOE, 296 & 277 \\
\multicolumn{1}{c}{ ESCRITORES ESTRANGEIROS } & ABREVIATURA & NÚMERO & 278 \\
96. ANSELMO, Manuel & MAns & MA-MOE, 298 & 282 \\
97. CHANTEPLEURE, Guy & GC & MA-MOE, 299 & 283 \\
98. FINGERIT, Marcos & MF & MA-MOE, 300 & 283 \\
99. GOLL, Ivan & IG & MA-MOE, 301 & 285 \\
100. GRAIVER, Bernardo & BG & MA-MOE, 302 & 286 \\
101. GUILLÉN, Alberto & AlbG & MA-MOE, 303 & 286 \\
102. HORIGOUTCHI, Nico D. & NH & MA-MOE, 304 & 287 \\
103. HUMMEL, Alexandre & & MA-MOE, 305 & 287 \\
& & & 288 \\
\hline
\end{tabular}

